\title{
Innowacje \\ w tańcuchach dostaw \\ źródłem przewagi \\ konkurencyjnej \\ w XXI wieku
}


类 


\section{Innowacje}

w tańcuchach dostaw

źródłem przewagi

konkurencyjnej

w XXI wieku

pod redakcją

Barbary Ocickiej i Magdy Zięby 
Barbara Ocicka, Magda Zięba - Uniwersytet Łódzki, Wydział Zarządzania Studenckie Koło Naukowe Zarządzania Łańcuchem Dostaw 90-237 Łódź, ul. Matejki 22/26

\author{
RECENZENT \\ Krzysztof Witkowski \\ REDAKTOR INICJUJĄCY \\ Monika Borowczyk \\ SKŁAD KOMPUTEROWY \\ Jakub Brzeziński \\ KOREKTA TECHNICZNA \\ Elżbieta Rzymkowska \\ PROJEKT OKŁADKI \\ Stämpfli Polska Sp. z o.o. \\ (C) Copyright by Authors, Łódź 2016
}

Zdjęcie wykorzystane na okładce: (C) Shutterstock.com

(C) Copyright for this edition by Uniwersytet Łódzki, Łódź 2016

Wydrukowano z gotowych materiałów dostarczonych do Wydawnictwa UŁ

Wydane przez Wydawnictwo Uniwersytetu Łódzkiego
Wydanie I W.07747.16.0.K

Ark. druk.10,25

ISBN 978-83-8088-496-0

e-ISBN 978-83-8088-497-7

Wydawnictwo Uniwersytetu Łódzkiego

90-131 Łódź, ul. Lindleya 8

www.wydawnictwo.uni.lodz.pl

e-mail: ksiegarnia@uni.lodz.pl

tel. (42) 6655863 


\section{SPIS TREŚCI}

Wprowadzenie.

Barbara OCICKA, Magda ZIĘBA

1. Wpływ digitalizacji na zarządzanie łańcuchem dostaw. 9

Oktawia BOGUSZ

2. Zarządzanie informacjami jako źródło przewagi konkurencyjnej

łańcucha dostaw w kontekście koncepcji Big Data.

Jakub BRZEZIŃSKI

3. Integracja łańcuchów dostaw poprzez wykorzystanie nowoczesnych technologii i systemów informatycznych

Barbara DUNIN-SULIGOSTOWSKA, Joanna SOWA

4. Dobre praktyki w obsłudze ładunków skonteneryzowanych w Porcie Szczecin.

Mateusz DZIECHCIARZ

5. Zrównoważone praktyki biznesowe w systemie zaopatrzenia przedsiębiorstwa - kryteria środowiskowe i społeczne oceny i segmentacji dostawców.

\section{Bożena GAJDZIK}

6. Wprowadzenie do oceny współpracy w łańcuchu dostaw na przykładzie operatora terminala kontenerowego i centrum logistycznego. 59 Aleksandra JANECZEK, Zuzanna NOWAK

7. Łańcuch dostaw lean czy agile - jak efektywnie i innowacyjnie zarządzać łańcuchem dostaw? 69

Katarzyna KOWALSKA, Justyna SIKORA

8. Wpływ automatyzacji i cyfryzacji na kształtowanie standardów obsługi klienta w usługach transportowych. 79

Marta LESZCZYŃSKA, Agata LEWANDOWSKA

9. Rozwój produktów polskiego przemysłu elektromaszynowego na przykładzie przedsiębiorstwa PESA Bydgoszcz S.A 91

Patryk MIKOEAJCZYK 
10. Grupy zakupowe jako innowacja organizacyjna w działalności małych i średnich przedsiębiorstw w Polsce.

Joanna PIORUNOWSKA-KOKOSZKO

11. Metody doskonalenia procesów i produktów na przykładzie japońskich technik zarządzania.

\section{Aleksandra REŃDA, Anita SIERADZKA}

12. Technologie przewozu i przeładunku elementów elektrowni wiatrowych w łańcuchu dostaw.

\section{Katarzyna TELEGA}

13. Subtropolis jako alternatywa dla tradycyjnych metod składowania zapasów.

Aleksander WOJTOWICZ

14. Zastosowanie modeli biznesowych uwzględniających e-commerce. 143 Natalia WÓJCIK

15. Internet Fizyczny jako przełom w zarządzaniu łańcuchami dostaw. 153 Magda ZIĘBA 
Niniejsze opracowanie stanowi zbiór artykułów nadesłanych na III Ogólnopolską Konferencję Naukową zorganizowaną w 2016 roku przez Studenckie Koło Naukowe Zarządzania Łańcuchem Dostaw, SKN SCM działające przy Katedrze Logistyki na Wydziale Zarządzania Uniwersytetu Łódzkiego. Temat przewodni tegorocznej Konferencji brzmiał: „Innowacje w łańcuchach dostaw źródłem przewagi konkurencyjnej w XXI wieku". Tym samym stał się on myślą przewodnią dla niniejszej publikacji.

W realiach współczesnej gospodarki innowacje są niezbędnym czynnikiem warunkującym rozwój organizacji, zdobywanie nowych rynków, a tym samym budowanie trwałej przewagi konkurencyjnej. Istnieje wiele definicji pojęcia innowacji. Według P. F. Druckera „innowacja jest szczególnym narzędziem przedsiębiorców, za pomocą którego ze zmiany czynią oni okazję do podjęcia nowej działalności gospodarczej lub świadczenia nowych usług". Każda innowacja jest zatem zmianą. Co do zasady powinna być zmianą na lepsze, aby przynieść firmie wymierne korzyści. Innowacji nie należy utożsamiać jedynie $\mathrm{z}$ wynalazkami czy nowymi produktami. Innowacje technologiczne mają na celu rozwój produktów i usług, stąd mogą być uważane za najważniejsze, ale jednocześnie są bardzo kosztowne. Innowacje procesowe dotyczą implementacji zmian m.in. $\mathrm{w}$ procesie produkcji czy świadczenia usług. Z kolei innowacje organizacyjne, często nie wymagają nakładów finansowych, polegają na zmianie sposobu funkcjonowania przedsiębiorstwa. Tak szeroko pojęte innowacje stały się dla Autorów nieocenionym źródłem inspiracji.

Niniejsza publikacja traktuje bowiem o zmianach i innowacjach w zarządzaniu łańcuchem dostaw na przełomie kilku a nawet kilkudziesięciu ostatnich lat. Autorzy podjęli tematykę o bardzo szerokim zakresie czasu. Zebrane referaty dotyczą fundamentalnych zmian, które stanowczo wpłynęły na rozwój łańcuchów dostaw i z czasem stały się ich nieodzownym elementem. Niektóre z nich zyskały miano kamieni milowych. Część artykułów poświęcona jest obecnie funkcjonującym procesom w perspektywie najlepszych praktyk. Zaś niektóre artykuły nakreślają wizję przyszłości, bowiem prezentują innowacje, które są dopiero w fazie projektowania i opracowania. Stwarza to dla Czytelnika szerszą perspektywę oraz pozwala zauważyć tempo zmian. Szczególnej wartości dodaje fakt, że opisane zagadnienia dotyczą różnych branż oraz procesów biznesowych.

${ }^{1}$ P. F. Drucker, Innowacja i przedsiębiorczość. Praktyka i zasady, PWE, Warszawa 1992, s. 23. 
Ufamy, iż publikacja dostarczy bodźców do dalszych rozważań oraz zachęci do prowadzenia głębszych badań i analiz, gdyż innowacje są tematem niezwykle aktualnym, stwarzającym nieograniczone możliwości nie tylko młodym naukowcom, ale także przyszłym menedżerom oraz właścicielom firm.

Barbara Ocicka

Opiekun Naukowy SKN Zarządzania Łańcuchem Dostaw w latach 2013-2016

Magda Zięba

Przewodnicząca SKN Zarzadzania Łańcuchem Dostaw w latach 2015-2016

Łódź, sierpień 2016 r. 
Oktawia Bogusz

Uniwersytet Łódzki

Katedra Logistyki

ul. Matejki 22/26, 90-237 Łódź

\section{Wpływ digitalizacji na zarządzanie łańcuchem dostaw}

\section{WPROWADZENIE}

Rozdział poświęcony jest badaniu wpływu digitalizacji na zarządzanie łańcuchem dostaw. Wymieniona tendencja stała się wzorem stopniowych zmian, a także wyzwaniem dla zarządzania procesami. Digitalizacja to termin opisujący integrację technologii cyfrowych $\mathrm{w}$ codziennym życiu poprzez cyfryzację wszystkich możliwych aspektów. Idea rewolucji naukowo-technicznej, która rozpoczęła się między 1950 a 1970 rokiem, wyniknęła ze zmiany metody analogowej, mechanicznej i elektronicznej na technologię cyfrową wraz z szybkim wzrostem produkcji komputerów i cyfrowego zapisu danych. Rewolucja trwa po dzień dzisiejszy. Digitalizacja może być również określana jako proces rozwijania się biznesu i przejście w kierunku cyfryzacji procesów. Innymi słowy jest to wykorzystanie technologii cyfrowych, aby zmienić model biznesowy oraz stworzyć nowe możliwości dodania wartości w biznesie i wygenerować większy obrót.

\subsection{PojęCie digitalizacji}

Digitalizacja została wprowadzona przez Gottfrieda Wilhelma Leibniza, który opracował transformację od liczby arabskiej do ciągów binarnych. Na przykład arabska liczba ' 26 ' może być zaszyfrowana do ciągu cyfrowego '1 11010 1'. Wstępne zastosowanie cyfrowego przekazu informacji odbywało się za pomocą techniki sygnału alfabetu Morse’a, który w 1835 roku przy użyciu sygnałów przekazywany był przez telegraf. Od 1943 do 1946 roku Bell Labs używał PCM ${ }^{2}$ w tajnym szyfrowaniu połączeń telefonicznych o nazwie SIGSALY. Pierwsza linia telefoniczna używała próżniowej inwersji częstotliwości do kodowania transmisji pomiędzy Winstonem Chirchillem i Franklinem Rooseveltem podczas II wojny światowej.

Pierwszy elektroniczny komputer, wynaleziony w 1939 roku przez Johna V. Atanasoffa i Clifforda Berry'ego, zawierał urządzenie pamięci masowej - bęben, który miał $\mathrm{w}$ swoim zastosowaniu kondensatory znajdujące się na jego powierzchni, aby tymczasowo przechowywać dane. Wprowadzenie

${ }^{1} 0 \times 2^{0}+1 \times 2^{1}+0 \times 2^{2}+1 \times 2^{3}+1 \times 2^{4}=26$.

${ }^{2} \mathrm{PCM}$ - ang. Pulse Code Modulation, czyli metoda reprezentacji sygnału analogowego w systemach cyfrowych. 
pierwszego komputera personalnego (PC) o nazwie Simon odbyło się w 1950 roku. Następnie po wielu usprawnieniach możliwości wyświetlania koloru, pracy wielozadaniowej z udziałem wielu użytkowników, a także wynalezieniu dyskietki i twardego dysku, płytach CD i DVD oraz innych uzupełnieniach komputerów, a także rozpowszechnieniu telefonów komórkowych dochodzimy do obecnego stanu digitalizacji, który wciąż się rozwija i jest powodem diametralnych zmian w pracy i życiu ludzi, które nazywane są rewolucją naukowo-techniczną znaną również jako trzecia rewolucja przemysłowa, zapoczątkowując erę informacyjną. Zasadniczym elementem dla transformacji jest produkcja masowa i powszechne stosowanie układów logicznych i ich pochodnych technologii. W najbliższej przyszłości Internet Rzeczy połączy wszystkich i wszystko w jednolitą sieć. Ludzie, maszyny, zasoby naturalne, linie produkcyjne, sieci logistyczne i praktycznie każdy inny aspekt życia gospodarczego i społecznego zostaną połączone w jedną platformę stale dostarczającą duże ilości danych. Te z kolei będą analizowane, przekształcane $\mathrm{w}$ algorytmy predykcyjne i zaprogramowane do zautomatyzowanych systemów w celu poprawy termodynamicznej wydajności, znacznie zwiększając produktywność i obniżając koszt.

\subsection{Digitalizacja I InTERnet}

Poprzednik Internetu pojawił się pod koniec lat 60. XX wieku. Oddział Departamentu Obrony Stanów Zjednoczonych rozwinął sieć do połączenia uczelni i przedsiębiorców z branży obronnej. Później, sieci regionalne współdzieliły dostęp z „superkomputerem” za pomocą szkieletowej topologii Internetu, która została wdrożona w połowie lat 80. W 1986 roku wprowadzono protokół TCP/IP, który jest podstawą dzisiejszego Internetu. Internet używany w dzisiejszych czasach został wprowadzony w 1989 roku o nazwie Word Wide Web jako system powiązanych stron $\mathrm{z}$ elementami graficznymi, możliwymi do odczytania tylko przy użyciu przeglądarki. Dodatkowo w 2004 roku, kod Morse’a został przedłużony o ' $\Delta--\Delta--\Delta$ ' oznaczający symbol '@' używany w adresach mailowych. Według struktury technologicznej Internetu, digitalizacja może być podzielona na trzy segmenty: sieć, usługi IT i dobra cyfrowe. Rysunek 1 przedstawia, jak usługi IT zarządzają i kontrolują sieć oraz dobra cyfrowe. Indywidualne oprogramowanie cyfrowe również jest częścią usług IT. Pliki wideo i muzyczne są towarami cyfrowymi, które mogą być przesyłane przez Internet i przechowywane w bazach danych. Odnosząc się do przecięcia trzech obszarów, 'Aplikacje Internetowe’ oznaczają złożoność produktów, które mają opierać się na sieci, usługach i dobrach cyfrowych. To jest powód, dla którego termin Internet zazwyczaj jest używany jako synonim digitalizacji, choć jest to technicznie nieprecyzyjne. 


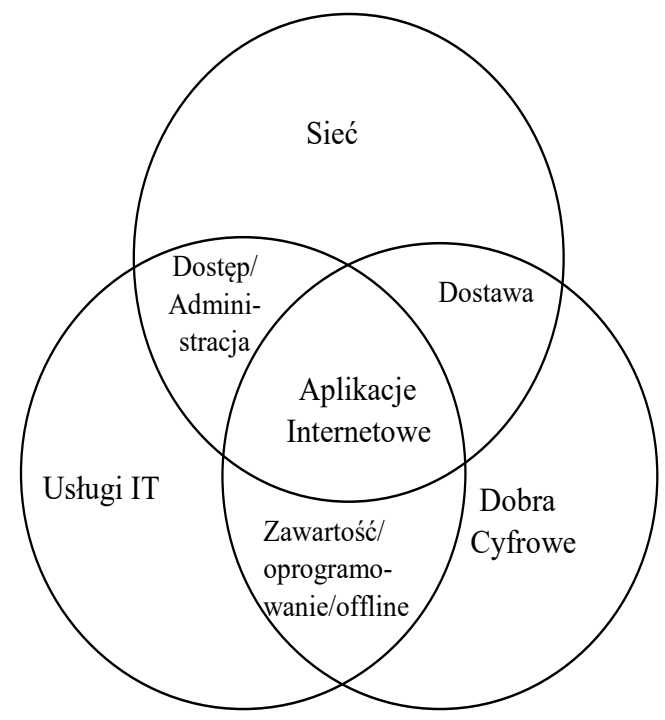

Rysunek 1. Relacja pomiędzy cyfrowymi dobrami, usługami IT oraz siecią Źródło: M. Vogelsang, Digitalisation in open Economies, Physica-Verlag, Berlin 2010, s. 4.

\subsection{Logistyka vs Łańcuch Dostaw}

Terminy „logistyka” i „zarządzanie łańcuchem dostaw” są czasem używane wymiennie, ale granica między nimi jest wyraźnie widoczna. Zgodnie z definicją M. Christophera, logistyka jest w zasadzie początkową orientacją oraz podbudową, która ma na celu stworzenie jednolitego planu dla przepływu produktów i informacji w ramach działalności gospodarczej. Zarządzanie łańcuchem dostaw opiera się na tej podbudowie i dąży do osiągnięcia koordynacji pomiędzy procesami innych podmiotów na drodze przepływu, czyli u dostawców i klientów, oraz organizacją samą w sobie. $\mathrm{W}$ ten sposób, zarządzanie łańcuchem dostaw to szersze pojęcie niż logistyka.

Zarządzanie łańcuchem dostaw obejmuje optymalny transport surowców lub produktów z jednego etapu do następnego. Jego celem jest zrównoważenie podaży i popytu. Osiągnięcie równowagi może się odbyć poprzez prognozowanie popytu oraz stworzenie wystarczającej ilości zapasu. W przeszłości popyt był często postrzegany jako podana informacja, a firma musiała reagować w najlepszy możliwy sposób, mając w zanadrzu mniej dokładne prognozy. Obecniekorporacje przyjmują bardziej aktywną postawę, ponieważ zauważono, że nie tylko działania wykonywane przez firmy, takie jak wprowadzenie nowego produktu, promocje, kampanie reklamowe mają wpływ na popyt, ale również niestabilność rynku, z którą można sobie skutecznie poradzić, jeżeli wdrożone jest odpowiednie planowaniełańcucha dostaw. 


\subsection{Rola Digitalizacji w Kluczowych Procesach}

Organizacja Global Supply Chain Forum wskazała osiem kluczowych procesów, które składają się na trzon zarządzania łańcuchem dostaw: - zarządzanie relacjami z klientami,

- zarządzanie obsługą klienta,

- zarządzanie popytem,

- realizacja zamówień,

- zarządzanie przepływem produkcji,

- zaopatrzenie,

- rozwój i komercjalizacja produktu,

- zarządzanie zwrotami.

Każdy proces posiada podprocesy na poziomie strategicznym i operacyjnym. Proces zarzadzania relacjami $z$ klientami ma na celu rozwijanie i utrzymywanie tejże korelacji. Na poziomie operacyjnym realizuje się założenia strategiczne, a podprocesy wyglądają następująco: zróżnicowanie klientów, przygotowanie zespołu zarządzającego kategoriami lub segmentami, wewnętrzna analiza kategorii konsumentów, zdefiniowanie możliwości dla konkretnych kategorii, opracowanie umowy dla towaru albo usługi, realizacja porozumienia i pomiar wydajności oraz generowanie raportów rentowności. Przed erą digitalizacji różnica pomiędzy CRM i CSM w zasadzie nie istniała. W przeszłości, konieczność ciągłego przepływu informacji pomiędzy tymi dwoma działaniami wywołała potrzebę posiadania jednego zespołu, aby troszczyć się o wszystkie aspekty związane z klientami. Dlatego też, przed rozwiązaniami stosowanymi w dzisiejszych czasach, usprawnienia cyfrowe były jedynie abstrakcją, a w rzeczywistości to one stworzyły proces zarządzania relacjami z klientami. Rozważając podproces zróżnicowania klientów okazuje się, że każdy konsument posiada konto ze zgromadzonymi informacjami na jego temat i historią zamówień. Pozwala to na używanie potężnych baz do oceny danych, a zatem na klasyfikację klientów. Przed pojawieniem się tej możliwości informacje o klientach były gromadzone $\mathrm{w}$ formie papierowej, ale prawdopodobnie nie było czasu, ani dobrego pomysłu na poprawną ewaluację, ze względu na ograniczenia ludzkiej natury. Obecnie istnieją odpowiednie programy i aplikacje, które są zdolne do tworzenia baz danych opartych na zapisie każdej sprzedaży. Dostępne są narzędzia CRM, gdzie każda rozmowa telefoniczna, czy też konwersacja przez e-mail może być zapisana. To z kolei daje możliwość wewnętrznej analizy każdej kategorii konsumentów i ewentualności dla każdego $\mathrm{z}$ nich, tym samym można $\mathrm{w}$ prosty sposób przeprowadzać negocjacje dopasowanych warunków. Następnie, pomiar efektywności i generowanie raportówrentowności jest znacznie łatwiejsze przy użyciu systemów IT, które mogą pobrać odpowiednie i potrzebne dane z bazy, a następnie przeprowadzić stosowne obliczenia. 
Zarzadzanie obsługa klienta jest skoncentrowane na dostarczaniu informacji do klienta, dotyczących dostępności produktów, terminów dostawy oraz szczegółów na temat przesyłki. Na poziomie operacyjnym odpowiedzialność w procesie polega na reagowaniu na zdarzenia zarówno zewnętrzne, jak i wewnętrzne. Podprocesy wyglądają następująco: rozpoznanie zdarzenia, ocena sytuacji i możliwości, implementacja rozwiązań, monitorowanie i raportowanie wydajności. Należy zauważyć, że działania dotyczące identyfikacji, ewaluacji i monitorowania były na niskim poziomie, ze względu na brak dostępności odpowiednich narzędzi. Przed erą Internetu koncentracja na kliencie także była mniejsza. Klient w celu zdobycia produktu lub usługi, musiał się pofatygować, aby go otrzymać. Jednym z powodów była mniejsza dostępność informacji na temat dóbr i usług w porównaniu do dzisiejszych czasów. Warto przedstawić przykład firmy Dow Chemicals. W przeszłości klienci, którzy chcieli otrzymać dokumentację techniczną produktu musieli zadzwonić i złożyć zamówienie. Poszczególne karty katalogowe $\mathrm{z}$ dokumentacją były wtedy wysyłane pocztą tradycyjną do klienta, który kilka dni później, po otrzymaniu arkuszy, mógł sobie zdać sprawę, że te konkretne produkty nie spełniają jego oczekiwań. Wtedy musiałby zadzwonić, w czasie pracy obiektu i zamówić więcej arkuszy z dokumentacją techniczną. Obecnie klienci mogą zalogować się na stronie dow.com 24 godziny na dobę, wyszukać odpowiednie karty katalogowe, pobrać je i/lub wydrukować. Proces zbierania informacji nie jest już wielodniowym i wielopodmiotowym zadaniem, które może obejmować kilka powtórzeń. Zamiast tego dostępność danych jest łatwa i ciągła. Firma oszacowała, że oszczędza $1 \mathrm{mln}$ USD miesięcznie na drukowaniu i wysyłce pocztowej, przez stworzenie klientom możliwości samoobsługi.

Proces zarzadzania popytem jest skoncentrowany na wyrównaniu potrzeb klientów $\mathrm{z}$ możliwościami podażowymi firmy. Innymi słowy, jest to koordynacja wszystkich działań, które stawiają popyt $\mathrm{w}$ zakresie produkcyjnym. Obejmuje prognozowanie popytu i zsynchronizowanie go z produkcją, zaopatrzeniem i dystrybucją. Na poziomie operacyjnym podprocesami są: zbieranie danych lub informacji, prognozowanie, synchronizacja, zwiększanie elastyczności i zmniejszanie zmienności oraz mierzenie wydajności. Przed wprowadzeniem Internetu, firmy mogły przewidywać zapotrzebowanie na podstawie popytu historycznego, co było najczęstszym rozwiązaniem. Szefowie magazynów, żeby nie być zaskoczonymi przez nagłe ilości zamówień, starali się utrzymywać dość duży poziom zasobów. Stosunkowo niedawnym rozwiązaniem dla relacji B2B jest monitorowanie poziomu towaru na półkach za pomocą kodu kreskowego do automatycznego sumowania sprzedaży i tym samym dostępności produktów. Połączenie pomiędzy bazą danych dostawcy oraz sklepu pozwala na szybką reakcję w obliczu braku towaru w sklepowym magazynie. Najważniejszym aspektem w dzisiejszym podejściu logistycznym jest obniżenie ilości zapasów, a tym samym zwiększenie szybkości przepływu. Planowanie łańcucha dostaw odbywa się przy 
pomocy wielu oprogramowań, które używając matematycznych algorytmów, pomagają osiągnąć wzrost płynności i ograniczyć ilość zapasów.

Realizacja zamówień jest kluczem do efektywnego zarządzania łańcuchem dostaw w zakresie spełniania wymagań klientów. Cel procesu można określić jako procent zamówień ukończonych bezbłędnie i bez żadnego uszkodzenia. Aby zapewnić skuteczne wykonanie zlecenia, proces wymaga pełnej integracji w firmie w zakresie produkcyjnym, logistycznym i rozwiązań marketingowych. Podczas spełniania wymagań klientów, współpraca pomiędzy kluczowymi członkami łańcucha dostaw powinna być rozwijana w celu zredukowania kosztu całkowitego. Na poziomie operacyjnym procesu realizacji zamówień, podprocesami są: generowanie i przekazanie zamówienia, wprowadzenie zamówienia, przetwarzanie zamówienia, obsługa dokumentacji, kompletacja zamówienia, dostarczenie zamówienia, wykonywanie czynności po realizacji dostawy, pomiar wyników. Rozważając wielkość procentową bezbłędnie dostarczonych zamówień, dawniej i teraz, nie zmieniła się ona przesadnie. W czasach przed pojawieniem się Internetu każda realizacja zlecenia była wykonywana $\mathrm{z}$ większą uwagą, ponieważ czas kompletacji był dłuższy. W dzisiejszych czasach, nie tylko kompletacja, ale cała realizacja zamówienia musi być wykonana $\mathrm{z}$ bardzo dużą prędkością, która $\mathrm{w}$ pewnych przypadkach może okazać się czynnikiem generującym błędy. Jednakże, urządzenia stosowane obecnie, wszelkiego rodzaju skanery, jak np. terminale kodów kreskowych, technologia pick-by-voice oraz pick-by-light, czyli kompletacja kierowana odpowiednio głosem lub światłem, redukują błędy w zakresie konfekcjonowania, zapewniając tym samym ciągłą inwentaryzację.

Proces zarzadzania przeplywem produkcji skoncentrowany jest na wytwarzaniu produktów i tworzeniu elastyczności produkcji, aby skutecznie obsługiwać rynek docelowy. Na poziomie operacyjnym proces wydaje się być tylko wewnętrznym zarządzaniem działaniami. $Z$ drugiej strony, niektóre jego cechy są zaprojektowane tak, aby zintegrować wewnętrzne zarządzanie firmy z działaniami łańcucha dostaw. Podprocesy wyglądają następująco: wyznaczanie trasy i prędkości poprzez planowanie i harmonogramowanie produkcji, synchronizacja zdolności przeładunkowej i popytu oraz pomiar wyników. Rozważając przepływ produkcyjny, można stwierdzić, że w przeszłości prędkość nie była czynnikiem łatwo osiągalnym. Pierwszym powodem dla postawienia takiej oceny sytuacji jest fakt ograniczenia dostępu i możliwości maszynowych. Większa część produkcji była wykonywana ręcznie. Montaż każdej części wymagał więcej wysiłku. W ten sposób każda wyprodukowana jednostka była droższa. To pociąga za sobą kolejny powód, a zatem ilościowo nie wytworzono zbyt dużo. Obecnie chodzi o to, aby zautomatyzować wszystko, co mogłoby być zautomatyzowane. Biorąc pod uwage produkcję plastikowych części, koszt wtryskarek jest duży, ale za to produkują one w krótkim czasie ogromne ilości. Po obliczeniach należy wyraźnie zaznaczyć, że 
praca ludzkich rąk jest znacznie droższa niż ta wykonywana przez maszyny. W ten sposób prezentowane zastosowanie digitalizacji znacznie obniża koszty.

Słowo zaopatrzenie (ang. procurement) jest źródłem konfuzji w opisie procesu. Odnosząc się do definicji, jest to „akt kupna”, który obejmuje wszystkie działania niezbędne do nabycia towarów. $Z$ drugiej strony jest to pozyskiwanie dóbr i usług dla przedsiębiorstwa, a tym samym proces $z a$ rzadzania relacjami $z$ dostawcami. Podobnie, jak fakt, że firma musi utrzymywać relacje $\mathrm{z}$ klientami, musi też wspierać te $\mathrm{z}$ dostawcami. Na poziomie operacyjnym zespół określa kryteria kategoryzacji dostawców oraz poziomy dostosowywania się do potrzeb. Podprocesy wyglądają następująco: zróżnicowanie dostawców, przygotowanie zespołu zarządzającego segmentem dostawców, wewnętrzny przegląd każdego segmentu dostawców, identyfikacja biznesowych możliwości z każdym dostawcą, opracowanie umowy dotyczącej produktu lub usługi i planu komunikacyjnego, wdrażanie porozumienia dotyczącego produktu lub usługi, pomiar wyników oraz wygenerowanie raportu dotyczącego kosztów i rentowności. Należy zauważyć, że zarządzanie relacjami z dostawcami (SRM) obecnie ulega znacznej transformacji. W przeszłości, nie było problemem wybrać odpowiedniego dostawcę. Obecnie istnieje o wiele więcej czynników wpływających na podjęcie tej decyzji. Specjalna technologia SRM pomaga zautomatyzować i uprościć proces, umożliwiając szybką i świadomą decyzję dotyczącą selekcji dostawców. Dlatego skuteczne działania SRM w dzisiejszych czasach generują duże oszczędności, jak i możliwości.

Rozwój i komercjalizacja produktów są kluczem do trwałego sukcesu firmy. Rozwój nowych produktów w krótkim czasie oraz wprowadzenie ich na rynek w sposób efektywny są głównymi składnikami sukcesu przedsiębiorstwa, co zagwarantowane jest dzięki zaangażowaniu klientów i dostawców w proces. Natomiast, aby pozostać konkurencyjnym, w momencie skracania się cyklu życia towaru, odpowiednie czynności powinny zostać opracowane i pomyślnie wdrożone w krótszych niż dotychczas oknach czasowych. Podprocesami na poziomie operacyjnym są: zdefiniowanie nowych produktów i poziomu dopasowania do rynku, ustalenie zespołu odpowiedzialnego za rozwój wielofunkcyjny produktu, ustanowienie ścieżki rozwoju produktu, projektowanie i budowa prototypów, podejmowanie decyzji, określenie sposobu dostępności, wyprowadzenie produktu oraz pomiar wydajności procesu. Dzisiaj, rynek to arena ciągłych zmian, a nagradzane są te firmy, które podejmują ogromne ryzyko podczas opracowywania nowych produktów. Powodem dla przyjęcia tego stanowiska jest fakt, że praktycznie wszystkie wymagania stawiane przez konsumenta są zaspokojone obecnymi rozwiązaniami produktowymi na rynku. Pozostał bardzo mały procent tego, co jeszcze nie zostało wynalezione, biorąc pod uwagę kontekst zapotrzebowania, a nie możliwości. Zamiast tworzyć kompletnie nowe produkty, badania są bardziej skoncentrowane na poszukiwaniu usprawnień $\mathrm{w}$ już istniejących. Weźmy pod uwagę potrzebę 
rozrywki, która może być zaspokojona przez kino. Wszystko zaczęło się od projektora i wyświetlania zdjęć w postaci slajdów. Po odpowiednich usprawnieniach byliśmy w stanie wyświetlać filmy, później również w kolorze. Po pewnym czasie pojawił się magnetowid, który służył zarówno do wyświetlania, jak i nagrywania filmów. Następnie kasety zmieniły się na płyty DVD, wkrótce po wynalezieniu płyt CD do komputera. Obecnie mamy do czynienia z płytami Blu-ray, nie wspominając już o prostej przenośnej pamięci USB, czy też twardym dysku. Wszystkie wymienione produkty zaspokajają tę samą potrzebę, jedynie nieznaczący w kontekście samej potrzeby sposób użytkowania się zmienia. Innymi słowy, mamy dostęp do bardzo bogatego wachlarza produktów, które w pewnych okolicznościach mogą wydać się niepotrzebne. Rozwój produktu służył ludziom zawsze w upraszczaniu ich życia. W rezultacie, powód dla powstania procesu rozwoju produktu się nie zmienił, tylko środki, czyli technologia oraz wyniki są na bardziej zaawansowanym poziomie.

Proces zarzadzania zwrotami jest zazwyczaj zaniedbany, a w zakresie jego możliwości znajduje się osiąganie trwałej przewagi konkurencyjnej. Efektywne zarządzanie zwrotami pozwala na identyfikację możliwości poprawy produktywności. Na poziomie operacyjnym proces skoncentrowany jest na aktywnościach związanych z codziennymi zwrotami, a podprocesami są: otrzymanie formularza zwrotu, ustanowienie tras, odbiór zwrotu, wybór stanowiska w sprawie, obciążenie klienta lub producenta, analiza powodu zwrotu i pomiar wyników. Historycznie rzecz biorąc, zarządzanie zwrotami może być datowane już od pierwszych zastosowań niechcianych przedmiotów. Pierwsi osadnicy używali wszystkiego, co mieli w posiadaniu, aby ułatwić sobie życie, tak jak chociażby wykorzystywanie starych ubrań i szmat do sporządzenia kołder. Amerykański sklep meblowy, Montgomery Wands założony w 1872 roku był pierwszą firmą, która posiadała dewizę 100\% satysfakcji klienta lub gwarancja zwrotu pieniędzy. W 1970 roku rozpoznano pierwszą powrotną drogę produktu, tj. od klienta do producenta. W latach 70. przepływ towaru połączony został z koncepcją troski o środowisko - green logistics. Logistyka zwrotu zaczęła się oddzielać od tradycyjnego przepływu towaru do przodu i została zdefiniowana jako proces planowania, realizowania i kontrolowania sprawnego i efektywnego kosztowo przepływu surowców, pólproduktów, wyrobów gotowych oraz informacji z nimi związanych z punktu konsumpcji do punktu pochodzenia w celu odzyskania wartości lub właściwej utylizacji. Przy opracowywaniu standardów i ewidencjonowaniu wyników stwierdzono, że w procesie brakuje odpowiedniej komunikacji. Digitalizacja stała się przyczyną rozwoju zarządzania zwrotami poprzez użycie tagów RFID. Obecne systemy potrafią nawet zaproponować pomysły na ponowne wykorzystanie produktów. W rezultacie drugie życie dla produktu lub też jego części ma większe szanse zostać osiągnięte. 


\subsection{INNOWACJE W LAŃCUCHU DOSTAW}

Innowacje mają na celu poprawę procesów w łańcuchach dostaw. Są one ważnym źródłem przewagi konkurencyjnej, a także podstawą do lepszych i bardziej trwałych wyników finansowych. Zarządzanie na każdym etapie łańcucha dostaw powinno być zrównoważone i proste, niezależnie od tego czy chodzi o produkcję, składowanie, transport, dostawę czy operacje dotyczące towarów w sklepie. Systemy informatyczne zrewolucjonizowały produktywność i dochodowość, zapewniając większą szybkość i wydajność, co pozwala na minimalizację strat. Jednakże, innowacyjność jest złożoną zdolnością.

W dzisiejszych czasach, transformacja do mobilności systemów informatycznych pozwala na komunikację w ruchu, a wynikiem tego jest lepsza organizacja w czasie i wzrost wydajności. Mobilność jest kluczem do dostarczania odpowiednich informacji do właściwej osoby we właściwym czasie. Jednakże, to nie jest nowa koncepcja, w rzeczywistości pierwsze tego typu rozwiązania zostały wprowadzone ponad 20 lat temu. Firmy, które na tym skorzystały, nadal są liderami $\mathrm{w}$ swoich branżach. Ponadto, ilość drukowanych dokumentów została zmniejszona, zapewniając zrównoważoną gospodarkę.

Innowacje mogą umożliwiać tworzenie nowych modeli firmy, ale $\mathrm{w}$ tym samych czasie przynoszą ogromne ryzyko. Biorąc pod uwagę fazę realizacji cyfrowych innowacji $\mathrm{w}$ organizacji, mogą wystąpić zakłócenia w zależności od tego, jak pracownicy radzą sobie z nauką nowego systemu. Dodatkowo, należy przyjąć, że komputer działa tylko na podstawie algorytmów $\mathrm{i} \mathrm{w}$ ten sposób brakuje mu ludzkiego rozumowania, stąd istnieje ryzyko prawdopodobieństwa błędów. Inne również występujące zagrożenia to przeprowadzane ataki cybernetyczne, których celem jest dezorientacja firmy. Niefrasobliwość pracowników to największe zagrożenie dla bezpieczeństwa korporacji. Inne dotyczą przestarzałych mechanizmów bezpieczeństwa informacji, przetwarzania danych $\mathrm{w}$ chmurze i niepewności urządzeń mobilnych.

Zgodnie $\mathrm{z}$ wynikami światowego badania bezpieczeństwa informacji, analizowanym przez GISS, który posiada wgląd do opinii 1775 uczestników z 67 krajów, okazuje się, że tylko 12\% firm odpowiedziało na atak hakerski w 10 minut, 25\% rozpoczęto dochodzenie po godzinie, a 33\% nawet o niczym nie wiedziało. W związku $\mathrm{z}$ tą sytuacją powstała tzw. ethical hacking, czyli kontrola ataków, która wspiera analizę postępowania w przedsiębiorstwach. Jednakże, odnosząc się do opinii 43\% respondentów, budżet przeznaczony na bezpieczeństwo danych przez następne 12 miesięcy utrzymuje się na poziomie z poprzedniego roku.

Co więcej, obecnie poziom terroryzmu spowodowany przez nowatorskie systemy jest bardzo wysoki, ale tym samym odpowiednio do poziomu digitalizacji ataki mogą zostać wykryte, a nawet przewidywane. 


\section{W jakim czasie firma średnio rozpoczyna dochodzenie po ataku hakerskim?}

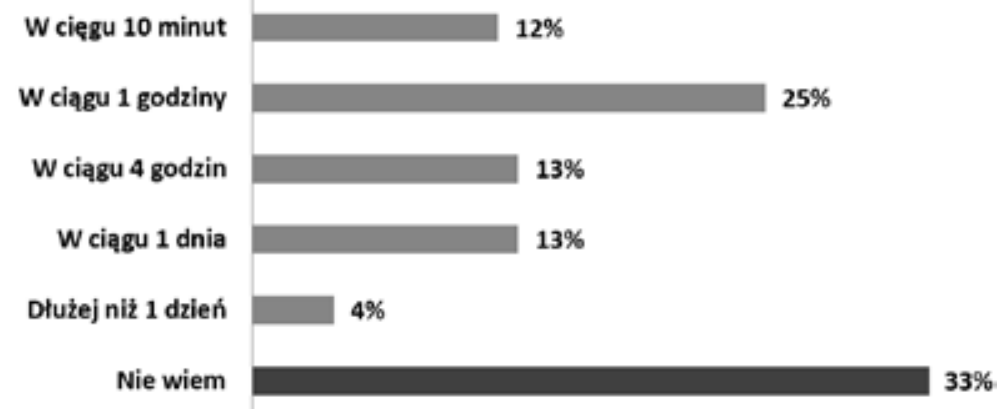

Wykres 1. Wyniki światowego badania bezpieczeństwa informacji

Źródło: M. Libiszewska, Zagrożenia z cyberprzestrzeni, „Logistyka a Jakość”, nr 6, 2014, s. 27.

Istnieje rozwiązanie dla niekorzystnych systemów informatycznych. Jest nim indywidualne opracowanie systemów IT, które są w pełni zintegrowane $\mathrm{z}$ procesami danej firmy. Przykładem wdrożenia takiej technologii jest firma Dachser, która ma oryginalnie opatentowane systemy: Domino, Mikado i Othello. Przedsiębiorstwo opracowało własny system, ponieważ żadne rozwiązanie dostępne na rynku dla transportu i gospodarki magazynowej nie spełniało wysokich wymagań jakościowych. Dlatego też, łańcuch dostaw z najlepszymi rozwiązaniami informatycznymi może decydować o przewadze konkurencyjnej.

\section{Podsumowanie}

Digitalizacja ma ogromny wpływ na zarządzanie łańcuchem dostaw. W każdym procesie SCM istnieje co najmniej jeden podproces, który przeszedł całkowitą zmianę $\mathrm{w}$ związku $\mathrm{z}$ innowacjami technologicznymi. Obecne technologie takie, jak: GPS, RFID i możliwości sensoryczne maszyn pozwoliły na przekształcenie istniejących struktur hybrydowych, czyli kombinacji papierowej i elektronicznej obsługi łańcucha dostaw, na bardziej elastyczne, sprawne, dogodne do współpracy modele cyfrowe. Istnieje również szereg aspektów negatywnych takich, jak ryzyko i znaczenie bezpieczeństwa ludzi i danych, które są obecnie zagrożone. Jednakże, pozytywne aspekty, oszczędność czasu i pieniędzy, większa wydajność i łatwiejsza komunikacja przyczyniają się do wykorzystania technologii w celu osiągnięcia ciągłego doskonalenia zarządzania łańcuchem dostaw. 


\section{Bibliografia}

Cooper M. C., Lambert D. M., Pagh J. D., Supply Chain Management: More than a New Name for Logistics, „The International Journal of Logistics Management”, No. 1, 1997.

Christopher M., Logistics and Supply Chain Management, Prentice Hall, Harlow 2011.

Croxton K. L., García-Dastugue S. J., Lambert D. M., Rogers D. S., The Supply Chain Management Processes, „The International Journal of Logistics Management”, No. 1, 2001.

Rogers D. S., Tibben-Lembke, Going backwards: Reverse logistics trends and practices, Reverse Logistics Executive Council, Reno 1998.

Wessels B., Inside the Digital Revolution, Ashgate, Aldershot 2007.

Vogelsang M., Digitalisation in open Economies, Physica-Verlag Heidelberg, Berlin 2010.

https://marketing.wharton.upenn.edu/files/?whdmsaction=public:main.file\&fileID=1872.

https://reverselogisticstalk.wordpress.com/category/returns-management.

http://www.businessdictionary.com/definition/digitalization.html. 

Mgr Jakub Brzeziński

Uniwersytet Łódzki

Katedra Logistyki

ul. Matejki 22/26, 90-237 Łódź

\section{Zarządzanie informacjami jako źródło przewagi konkurencyjnej lańcucha dostaw w kontekście koncepcji Big Data}

\section{WPROWADZENIE}

Wzrost ilości danych cyfrowych na świecie spowodował, iż konwencjonalne techniki ich przetwarzania i przechowywania stały się nieadekwatne do obecnych potrzeb. Jednocześnie zaczęto dostrzegać potencjał kryjący się w informacji jako jednym z czynników funkcjonowania przedsiębiorstw. Niniejszy rozdział powstał w związku z brakiem literaturowym, odnoszącym się do roli nowoczesnych środków gromadzenia i przetwarzania informacji na potrzeby ogniw łańcucha dostaw. Jego celem jest ukazanie informacji jako istotnego czynnika stanowiącego o pozycji konkurencyjnej łańcucha dostaw, jak również przedstawienie koncepcji Big Data, która może tę pozycję wzmacniać. Dla osiągnięcia celu, posłużono się metodą analizy literatury oraz dostępnych wyników badań.

\subsection{MIEJSCE INFORMACJI W ORGANIZACJI}

Główne czynniki mające wpływ na współczesne realia gospodarcze - postęp technologiczny oraz rosnąca globalizacja, doprowadziły do wzrostu zapotrzebowania na informacje, zauważalnego szczególnie w odniesieniu do zarządzania organizacjami. Według badań IDC, liczba bitów ${ }^{1}$ informacji przekroczyła liczbę gwiazd we wszechświecie już w 2008 roku² $^{2}$. Fakt, że badania nie objęły ostatnich lat, a więc okresu drastycznego rozwoju technologicznego, daje wyobrażenie o obecnej skali zjawiska.

We współczesnej literaturze można zaobserwować trend przywiązywania przez naukowców coraz większej wagi do informacji. Podczas gdy w przeszłości autorzy opisujący przedsiębiorstwa skupiali się na przepływach fizycznych i kapitałowych, informacja pozostawała niedoceniana. Poczynając od końca XX wieku, przedstawiciele doktryny prezentują podejście traktujące informacje jako zasób

\footnotetext{
${ }^{1}$ Najmniejsza jednostka informacji używana w odniesieniu do sprzętu komputerowego.

${ }^{2}$ The Diverse and Exploding Digital Universe, An IDC White Paper, http://www.ifap.ru/library/ book268.pdf [10.03.2016].
} 
przedsiębiorstwa ${ }^{3}$. J. Penc wyraża pogląd, że w nowocześnie zarządzanych przedsiębiorstwach informacje uznawane są za czwarty - obok ziemi, pracy i kapitału

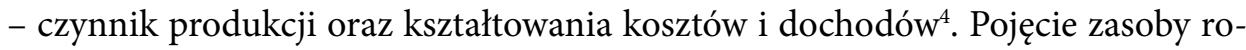
zumiane jest tu jako znajdujące się w dyspozycji przedsiębiorstwa czynniki wytwórcze, które mogą być wykorzystywane w procesach produkcyjnych i wymiany. Zgodnie z najczęściej występującą obecnie w literaturze klasyfikacją, dzieli się je na:

- zasoby finansowe,

- zasoby ludzkie,

- zasoby rzeczowe,

- zasoby informacyjne ${ }^{5}$.

Niektórzy autorzy w swoich rozważaniach idą jeszcze dalej. P. F. Drucker traktuje informację jako najważniejszy i najcenniejszy spośród zasobów oraz zauważa, że stopniowy zysk pochodzący z pracy, ziemi i pieniędzy staje się coraz mniejszy, a głównymi źródłami bogactwa są informacja i wie$\mathrm{dza}^{6}$. G. Urbanek określa zasoby oparte na wiedzy jako „ukryte”, zauważając że $\mathrm{w}$ przeważającej części, nie są one uwzględnione w bilansach przedsiębiorstw ${ }^{7}$. Rozwijając myśl tego autora można podjąć stwierdzenie, że wartości informacji nie da się wykazać, gdyż są one bezcenne. Przewaga konkurencyjna budowana na tym zasobie nie może zostać bowiem skwantyfikowana, jak choćby w przypadku przewagi opartej o jakość czy cenę, które można przedstawić za pomocą wymiernych wskaźników. Podążając zaś za Druckerem, rola informacji $\mathrm{w}$ organizacji, określona zostanie $\mathrm{w}$ artykule jako zasób primus inter pares - pierwszy pośród równych, z zastrzeżeniem, że odnosi się to do współczesnych organizacji dążących do uzyskania przewagi na rynku.

W świetle powyższych stwierdzeń, zasadne staje się sformułowanie traktujące informację jako element stanowiący o sile i konkurencyjności przedsiębiorstwa. Zauważyły to firmy, których kluczowa działalność opiera się o gromadzenie i przetwarzanie danych: Google, Ebay czy Facebook.

\subsection{WPEYW INFORMACJI NA KONKURENCYJNOŚĆ ŁAŃCUCHA DOSTAW}

Rola informacji wzrasta, gdy od przedsiębiorstwa przesuniemy się w stronę łańcucha dostaw, którego funkcjonowanie w dużej mierze oparte jest o ten zasób. Informacja umożliwia racjonalizację przepływu pozostałych strumieni (materia-

\footnotetext{
${ }^{3}$ Por. W. M. Grudzewski, I. K. Hejduk, Przedsiębiorstwo wirtualne, Difin, Warszawa 2002, s. 58; Przedsiębiorstwo wobec wspótczesnych wyzwań w procesie zarządzania, red. I. Hejduk, L. Ciborowski, Wydawnictwo Akademii Podlaskiej, Siedlce 2005, s. 24.

${ }^{4}$ J. Penc, Zarządzanie dla przyszłości. Twórcze kierowanie firma, Wydawnictwo Profesjonalnej Szkoły Biznesu, Kraków 1998, s. 46.

${ }^{5}$ Wprowadzenie do nauki o przedsiębiorstwie, red. M. Brzeziński, Difin, Warszawa 2007, s. 81-82.

${ }^{6}$ P. F. Drucker, Społeczeństwo pokapitalistyczne, WN PWN, Warszawa 1999, s. 149.

${ }^{7}$ G. Urbanek, Kompetencje a wartość przedsiębiorstwa, Wolters Kluwer, Warszawa 2011, s. 12.
} 
łów, kapitału, energii i ludzi), koordynację wewnątrz łańcucha dostaw i jego harmonijne powiązanie $z$ otoczeniem ${ }^{8}$.

Zainteresowanie informacją w łańcuchach dostaw zostało zauważone przez Ch. Bechtela i J. Jayarama, którzy zidentyfikowali cztery szkoły myślowe odnoszące się do teorii ich funkcjonowania: szkołę świadomości funkcjonalnej łańcucha, szkołę wspólnych powiązań, szkołę informacyjną oraz szkołę integracyjną ${ }^{9}$ Główny przedstawiciel szkoły informacyjnej - L. Johansson, wskazuje że zarządzanie łańcuchem dostaw „wymaga, aby wszyscy uczestnicy łańcucha dostaw byli właściwie informowani. W zarządzaniu łańcuchem dostaw, punkty styku oraz przepływy informacji między różnymi ogniwami łańcucha dostaw są krytycznymi elementami dla ostatecznych wyników jego funkcjonowania" ${ }^{10}$. Pogląd prezentowany przez szkołę informacyjną został w późniejszym czasie poddany rewizji i uwzględniony mutatis mutandis we współczesnych definicjach zarządzania łańcuchem dostaw.

W przypadku przepływów w łańcuchu dostaw, w znacznie większym stopniu niż wewnątrz niezwiązanych $\mathrm{z}$ nim przedsiębiorstw, wyzwanie stanowi ilość i złożoność informacji. Brak koherencji staje się niejednokrotnie przyczynkiem do występowania zakłóceń w relacjach pomiędzy poszczególnymi interesariuszami.

Przedsiębiorstwa będące ogniwami łańcucha dostaw muszą liczyć się z dłuższym czasem pozyskiwania i przekazywania informacji, jak również z większą dozą prawdopodobieństwa ich zniekształcenia. Dodatkowo, ze względu na długi czas pozyskiwania, informacje mogą ulegać dezaktualizacji i być po pewnym czasie całkowicie nieprzydatne. W konsekwencji może to prowadzić do komplikacji związanych z odpowiednim poziomem świadczenia usług i odejścia klienta do konkuren$\mathrm{cji}^{11}$. Należy jednak zaznaczyć, że w czasach gdy przedsiębiorstwa nie są w stanie wyeliminować nieokreśloności warunków funkcjonowania, czynnikiem, który pozwala ją przynajmniej zredukować, są odpowiednio zorganizowane i zarządzane zasoby informacyjne ${ }^{12}$. Jest to ściśle związane z konkurencyjnością, niezależnie od występujących w doktrynie deskrypcji przewagi konkurencyjnej. Według I. Rutkowskiego osiągnięcie takiej przewagi warunkują czynniki zewnętrzne w stosunku do firmy. Rynek, na którym działa przedsiębiorstwo, wywiera bowiem określoną presję. Przewagę konkurencyjną uzyskują te przedsiębiorstwa, które skuteczniej

\footnotetext{
${ }^{8}$ M. K. Gąsowska, System informacji jako narzędzie wspomagające zarządzanie logistyka w przedsiębiorstwie i łańcuchach dostaw, „Zeszyty Naukowe Politechniki Śląskiej: Organizacja i Zarządzanie”, z. 68, Gliwice 2014, s. 290.

${ }^{9}$ Ch. Bechtel, J. Jayaram, Supply Chain Management: A Strategic Perspective, „International Journal of Logistics Management", Vol 8, No. 1, 1997, s. 15-34.

${ }^{10}$ L. Johansson, How Can a TQEM Approach Add Value to Your Supply Chain?, „Total Quality Environmental Management", Vol. 3, No. 4, 1994, s. 525.

${ }^{11}$ M. K. Gąsowska, op. cit., s. 292.

${ }^{12}$ Zarzadzanie zasobami informacyjnymi $w$ warunkach nowej gospodarki, red. R. Borowiecki, J. Czekaj, Difin, Warszawa 2010, s. 144.
} 
dostosowują się do wymogów stawianych przez rynek ${ }^{13}$. Inny model wiąże przewagę konkurencyjną z posiadaniem przez firmę kompetencji, które wyróżniają ją od konkurencji i dają jej nad nią przewagę. Model ten ma swoje źródło w koncepcjach traktujących przedsiębiorstwo jako zbiór zasobów materialnych i niematerialnych. Przewaga konkurencyjna jest więc emanacją wewnętrznych zdolności przedsiębiorstwa do wykorzystywania możliwości i przeciwdziałania zagrożeniom ${ }^{14}$.

Informacje stają się zatem elementem ograniczającym ryzyko płynące $\mathrm{z}$ otoczenia oraz jak wykazano wcześniej, zasobem przedsiębiorstwa o kluczowym znaczeniu i potencjale. Przywiązywanie do nich wagi w łańcuchu dostaw, może przyczynić się do przekucia zagrożeń w potencjalne szanse, ergo - wzrostu konkurencyjności.

\subsection{CHARAKTERYSTYKA KONCEPCJI BIG DATA}

Koncepcja Big Data jest stosunkowo nową ideą, która wciąż nie ustabilizowała swojej pozycji w naukach o zarządzaniu. Obserwacje wskazują, że wielu przedstawicieli, zarówno nauki jak i biznesu, choć wie o istnieniu Big Data, nie potrafi tej idei bliżej określić czy dokonać jej oceny. Powodem takiego stanu rzeczy jest relatywnie krótka obecność koncepcji na rynku, która przekłada się na brak jednoznacznej definicji zagadnienia i jego deskrypcji. O Big Data się mówi, o Big Data się wie, lecz desygnat tego pojęcia $\mathrm{w}$ dalszym ciągu pozostaje otwarty na próby kompleksowego opracowania, szczególnie w przełożeniu na język polski.

Pierwsze próby definicji Big Data, tworzone przez liderów przemysłu analityczno-doradczego w zakresie technologii informatycznych, oparte były o identyfikację przymiotnikową. W 2001 roku firma Gartner (ówcześnie META Group) przedstawiła koncepcję „3V” - volume, velocity, variety, rozszerzając ją po 11 latach o variability i complexity. W roku 2012 pojawiła się koncepcja „4V” IBM odnosząca się do atrybutów: volume, velocity, variety, veracity. Poniższa tabela przybliża znaczenie poszczególnych pojęć.

Tabela 1. Zestawienie atrybutów Big Data

\begin{tabular}{|l|l|}
\hline \multicolumn{1}{|c|}{ Określenie } & \multicolumn{1}{c|}{ Charakterystyka } \\
\hline Volume & $\begin{array}{l}\text { Ilość - charakteryzuje się znaczącą dynamiką przyrostu danych, dla których } \\
\text { wymagane są nowe technologie bazodanowe. }\end{array}$ \\
\hline Velocity & $\begin{array}{l}\text { Szybkość - dane napływające szybko, strumieniowo, które w związku z proce- } \\
\text { sami biznesowymi wymagają dodatkowej mocy obliczeniowej do ich analizy } \\
\text { w czasie rzeczywistym. }\end{array}$ \\
\hline
\end{tabular}

${ }^{13}$ I. Rutkowski, Marketing jako źródło przewagi konkurencyjnej na rynku [w:] Marketing jako czynnik i instrument konkurencji, PWE, Warszawa 1997, s. 58.

${ }^{14}$ B. Godziszewski, Umiejętności firmy jako podstawa trwałej przewagi konkurencyjnej [w:] Restrukturyzacja i konkurencyjność przedsiębiorstw, red. R. Borowiecki, AE Kraków, Zakopane 1997, s. 30. 
2. ZARZĄDZANIE INFORMACJAMI JAKO ŹRÓDŁO PRZEWAGI KONKURENCYJNEJ ŁAŃCUCHA DOSTAW...

\begin{tabular}{|l|l|}
\hline \multicolumn{1}{|c|}{ Określenie } & \multicolumn{1}{c|}{ Charakterystyka } \\
\hline Variety & $\begin{array}{l}\text { Różnorodność - dane pochodzą z wielu źródeł i często występują w różnych } \\
\text { formatach i są zapisywane za pomocą różnych modeli oraz wyrażane w dowol- } \\
\text { nej formie, np.: liczbowo, tekstowo, obrazowo, dźwiękowo oraz generowane } \\
\text { w różny sposób. }\end{array}$ \\
\hline Variability & $\begin{array}{l}\text { Zmienność - dane, których natężenie jest zmienne w czasie, a przepływy da- } \\
\text { nych podlegają cyklom i trendom, a także szczytom, co związane jest również } \\
\text { z dynamiką procesów i zmian gospodarczych czy politycznych. }\end{array}$ \\
\hline Complexity & $\begin{array}{l}\text { Złożoność - złożoność danych jest ściśle związana z różnorodnością. Charak- } \\
\text { teryzuje się różnym uporządkowaniem danych. Są to dane o określonej struk- } \\
\text { turze, mające określony typ i format. }\end{array}$ \\
\hline Veracity & $\begin{array}{l}\text { Wiarygodność - unikatowa wartość informacyjna ukryta w dużych i złożo- } \\
\text { nych strukturach danych, dająca możliwość formułowania nowych wniosków, } \\
\text { które następnie przyczyniają się do wzrostu efektywności działania organizacji } \\
\text { na różnych płaszczyznach. }\end{array}$ \\
\hline
\end{tabular}

Źródło: opracowanie własne na podstawie: B. Franczyk, J. Korczak, M. Tabakow, Big Data - definicje, wyzwania i technologie informatyczne, „Informatyka ekonomiczna”, nr 31, 2014, s. 151-152.

$\mathrm{W}$ dalszej części pracy posłużono się definicją korzystającą z powyższych atrybutów, zaproponowaną na łamach „Informatyki ekonomicznej”, w myśl której „Big Data to określenie stosowane dla takich zbiorów danych, które jednocześnie charakteryzują się dużą objętością, różnorodnością, strumieniowym napływem w czasie rzeczywistym, zmiennością, złożonością, jak również wymagają zastosowania innowacyjnych technologii, narzędzi i metod informatycznych w celu wydobycia z nich nowej i użytecznej wiedzy"15.

Metody Big Data uważa się za zbliżone bardziej do metod eksploracji niż do metod analizy statystycznej. W konsekwencji ich stosowania dochodzi do "odkrywania” nowych, często do tej pory nieznanych zależności między danymi, a nawet do "odkrywania nowych zjawisk” przydatnych $\mathrm{w}$ procesach poznawczych, badawczych czy decyzyjnych ${ }^{16}$. Big Data stanowi jedno $\mathrm{z}$ najważniejszych wyzwań współczesnego świata cyfrowego. Możliwości przetwarzania dużych ilości danych o różnym typie i dużej złożoności, pochodzących $\mathrm{z}$ różnych źródeł informacyjnych, znajdują zastosowanie $\mathrm{w}$ wielu dziedzinach: typowo naukowo-badawczych i komercyjnych. Zastosowania komercyjne dotyczą praktycznie każdej branży, ponieważ w sposób pośredni lub bezpośredni polityka firm uzależniona jest od dostępu do informacji i analizy odpowiednich danych ${ }^{17}$.

${ }^{15}$ B. Franczyk, J. Korczak, M. Tabakow, Big Data - definicje, wyzwania i technologie informatyczne, „Informatyka ekonomiczna”, nr 31, 2014, s. 141.

${ }^{16}$ Internet. Publiczne bazy danych i Big Data, red. G. Szpor, C.H. Beck, Warszawa 2014, s. 11.

${ }^{17}$ B. Franczyk, J. Korczak, M. Tabakow, op. cit, s. 151. 


\subsection{Big Data źRódeEM PRZEWAgi KONKuRENCYJNEJ LAŃCUCHóW DOSTAW}

Przedsiębiorstwa będące ogniwami każdego z łańcuchów dostaw dysponują ogromną ilością informacji. Aby jednak mogły one stać się par excellence przewagą konkurencyjną, muszą zostać zrewidowane i wykorzystane w odpowiedni dla łańcucha sposób. Analiza Big Data sprzyja w tej materii podniesieniu wydajności działalności operacyjnej łańcucha, obsługi klienta oraz umożliwia kreowanie nowych modeli biznesowych.

Tworząc perspektywę rozwoju Big Data, firma DHL sprecyzowała pięć obszarów, w których koncepcja ta odniesie największy sukces w kontekście zarządzania łańcuchem dostaw ${ }^{18}$. W swoim opracowaniu, firma skupiła się na: optymalizacji działalności podstawowej, usprawnieniach dystrybucji, synchronizacji interesariuszy, budowie sieci informacyjnej oraz zwiększaniu zasięgu geograficznego.

Optymalizacja właściwości usług takich, jak czas dostawy, wykorzystanie zasobów, zasięg geograficzny, należy do podstawowych wyzwań dla łańcuchów dostaw. Działania prowadzone na wielką skalę wymagają informacji dla prawidłowej realizacji poszczególnych zadań, przy czym im wcześniej się one pojawiają, im są dokładniejsze i im jest ich więcej, efekty optymalizacji są bardziej widoczne. Zaawansowane technologie przewidywania zachowań rynkowych oraz przetwarzanie ogromnej ilości danych w czasie rzeczywistym to kluczowe funkcje Big Data, przekładające się na wysokiej jakości prognozy.

Big Data jest również otwartą księgą, z której można wyczytać upodobania klienta na etapie dystrybucji produktów. W skali globalnej, miliardy konsumentów odbywają codziennie interakcje związane $\mathrm{z}$ nabywaniem produktów i usług, zostawiając swój ślad w miejscach styku z ogniwem dystrybucyjnym - w sklepach, w Internecie czy w przenośnych terminalach kurierów. Gromadzenie wszystkich danych jako Big Data, daje możliwość poznania prawdziwego feedbacku w dowolnym kształcie i na dowolnym rynku. Dyrektor badań Google - P. Norvig powiedział kiedyś, że „sukces firmy to nie lepsze algorytmy, lecz większa ilość danych"19, co pokazuje, gdzie warto szukać przewagi konkurencyjnej.

Posiadanie informacji i ich odpowiednie przetwarzanie prowadzą również do wzmocnienia odporności łańcuchów dostaw na zagrożenia (ang. supply chain resilience). Poprzez szybką analizę strumieni danych pochodzących od poszczególnych ogniw łańcucha dostaw, Big Data umożliwia przygotowanie właściwych prognoz oraz scenariuszy związanych z potencjalnym zagrożeniem dla ciągłości działania. Koncepcja sprawia, że dane są bardziej przejrzyste i dostępne z większą częstotliwością, co pozwala szybko wychwycić zachodzące zmiany. Minimalizując w ten sposób

\footnotetext{
${ }^{18}$ Big Data in Logistics. A DHL perspective on how to move beyond the hype, December 2013, http:// www.dhl.com/content/dam/downloads/g0/about_us/innovation/CSI_Studie_BIG_DATA.pdf [14.03.2016].

${ }^{19}$ A. McAfee, E. Brynjolfsson, Big Data: The Management Revolution, „Harvard Business Review”, October 2012, s. 63.
} 
ryzyko, informacje służą jako „parasol ochronny” dla łańcucha, osłaniając go przed zdarzeniami, które mogą obniżyć efektywność działań konkurencji rynkowej.

Tabela 2 przedstawia szczegółowe możliwości Big Data dla użytkowników w ramach łańcucha dostaw.

Tabela 2. Wpływ Big Data na ogniwa łańcucha dostaw

\begin{tabular}{|l|l|}
\hline \multicolumn{1}{|c|}{ Możliwości Big Data } & \multicolumn{1}{|c|}{ Przykłady oddziaływania } \\
\hline $\begin{array}{l}\text { Bardziej przejrzyste i częściej wykorzy- } \\
\text { stywane informacje }\end{array}$ & $\begin{array}{l}\text { - Poprawa doświadczeń klientów na bieżąco } \\
\text { - Przejście od relacji antagonistycznych do kolabora- } \\
\text { tywnych w ramach łańcucha dostaw }\end{array}$ \\
\hline $\begin{array}{l}\text { Identyfikacja ukrytych relacji, wzorców } \\
\text { i trendów dotyczących zbiorów danych, } \\
\text { takich jak zachowania indywidualne lub } \\
\text { grupowe }\end{array}$ & $\begin{array}{l}\text { - Przewidywanie i zapobieganie problemom oraz za- } \\
\text { grożiom w firmie zanim staną się one faktem } \\
\text { galnych działań } \\
\text { - Natychmiastowa identyfikacja i powstrzymanie } \\
\text { wszelkich naruszeń zasad bezpieczeństwa i zgodności }\end{array}$ \\
\hline $\begin{array}{l}\text { Rozwój produktów i usług nowej ge- } \\
\text { neracji dzięki wykorzystaniu Internetu } \\
\text { Rzeczy lub danych osobowych dotyczą- } \\
\text { cych lokalizacji }\end{array}$ & $\begin{array}{l}\text { - Proaktywne utrzymanie zasobów zapobiegające } \\
\text { awarii komponentów } \\
\text { dnia lub sąsiadujące treści }\end{array}$ \\
\hline $\begin{array}{l}\text { Przekształcenie alokacji zapasów w pro- } \\
\text { ces interaktywny }\end{array}$ & $\begin{array}{l}\text { - Dokładne przewidywanie zapotrzebowania klienta } \\
\text { w stosunku do poziomu zapasów i natychmiastowe } \\
\text { dopasowanie odpowiednich działań }\end{array}$ \\
\hline $\begin{array}{l}\text { Bardziej szczegółowy wgląd w osiągane } \\
\text { wyniki oraz pokazanie zmienności }\end{array}$ & $\begin{array}{l}\text { - Monitorowanie i utrzymanie dostępności i prze- } \\
\text { pustowości połączonej infrastruktury składającej się } \\
\text { m.in. z sieci użytkowych, sieci komputerowych i za- } \\
\text { kładów produkcyjnych }\end{array}$ \\
\hline $\begin{array}{l}\text { Przeprowadzanie kontrolowanych eks- } \\
\text { perymentów, analiz typu „co jeśli”, sy- } \\
\text { mulacji i modelowania }\end{array}$ & $\begin{array}{l}\text {-Zrozumienie wpływu podejmowanych decyzji przed } \\
\text { rozpoczęciem działań }\end{array}$ \\
\hline
\end{tabular}

Źródło: Osiagganie korzyści z Big Data: skup się na możliwościach, a nie na przeszkodach, SAP, 2014, http://go.sap.com/poland/docs/download/2015/08/de20afbb-377c-0010-82c7-eda71af511fa.pdf [16.03.2016].

Możliwości wpływu Big Data na łańcuch dostaw są praktycznie nieograniczone i zależą od kreatywności menedżerów. Zastosowanie koncepcji w każdym z wymienionych obszarów łańcucha dostaw prowadzi do podniesienia jego konkurencyjności. Czy będzie to trafniejsza ocena potrzeb klientów lub rynku? Czy zapewni lepsze dopasowanie produktów i usług do aktualnych trendów? Szanse, by wyprzedzić konkurencję, rosną w przypadku korzystania z Big Data. Wyniki 
badań z 2013 roku ${ }^{20}$ pokazują, że 60\% przedsiębiorstw planuje podjąć inwestycje w narzędzia analityczne Big Data w ciągu pięciu lat. Jest to wyrazem ważnej roli, jaką informacja odegra w rzeczywistości gospodarczej.

\section{Podsumowanie}

Informacja w łańcuchu dostaw odgrywa niezwykle istotną rolę i powoli zaczyna być doceniana przez menedżerów, zajmując uprzywilejowane miejsce pośród zasobów przedsiębiorstw. Jednak nie da się ukryć, że potencjał ukryty w danych informacyjnych nie jest jeszcze odkryty. Stanowi to wyzwanie zarówno dla praktyki biznesowej, jak i naukowców. Gwałtowny rozwój trendu informacyjnego może stać się przyczynkiem do prowadzenia badań w zakresie określania wpływu informacji na pozycję konkurencyjną łańcuchów dostaw. Przedmiotem zainteresowania naukowców w tym kontekście powinna stać się koncepcja Big Data, będąca przyszłą emanacją biznesowego sukcesu. Trend kształtujący nieprzeciętną wartość płynącą $\mathrm{z}$ danych widać również $\mathrm{w}$ świecie nauki, pod postacią licznie otwieranych kierunków studiów związanych $\mathrm{z}$ analizą danych czy analityką dla biznesu. Trudno się zatem nie zgodzić ze stwierdzeniem, że choć nasze czasy to dopiero świt Big Data, to codziennie stykamy się z tą koncepcją ${ }^{21}$.

\section{Bibliografia}

Bechtel Ch., Jayaram J., Supply Chain Management: A Strategic Perspe-ctive, „International Journal of Logistics Management", Vol 8, No. 1, 1997.

Drucker P. F., Społeczeństwo pokapitalistyczne, PWN, Warszawa 1999.

Franczyk B., Korczak J., Tabakow M., Big Data - definicje, wyzwania i technologie informatyczne, „Informatyka ekonomiczna”, nr 31, 2014.

Fechner I., Zarządzanie łańcuchem dostaw, Wyższa Szkoła Logistyki, Poznań, 2007.

Gąsowska M. K., System informacji jako narzędzie wspomagające zarządzanie logistyka w przedsiębiorstwie i łańcuchach dostaw, Zeszyty Naukowe Politechniki Śląskiej: Organizacja i Zarządzanie, z. 68, 2014.

Godziszewski B., Umiejętności firmy jako podstawa trwałej przewagi konkurencyjnej [w:] Restrukturyzacja i konkurencyjność przedsiębiorstw, red. Borowiecki R., AE Kraków, Zakopane, 1997.

Grudzewski W. M., Hejduk I. K., Przedsiębiorstwo wirtualne, Difin, Warszawa 2002.

Johansson L., How Can a TQEM Approach Add Value to Your Supply Chain?, „Total Quality Environmental Management", Vol. 3, No. 4, 1994.

Mayer-Schonberger V., Cukier K., Big Data. A revolution that will transform how we live, work, and think, HMH, Boston - New York 2013.

McAfee A., Brynjolfsson E., Big Data: The Management Revolution, „Harvard Business Review”, October 2012.

${ }^{20}$ Trends and Strategies in Logistics and Supply Chain Management, BVL International, 2013, http://picsbelgium.be/wp-content/uploads/2013/07/BVL_TrendsandStrategies_SCM_Logistics_2013_pdf.pdf [14.03.2016].

${ }^{21}$ V. Mayer-Schonberger, K. Cukier, Big Data. A revolution that will transform how we live, work, and think, HMH, Boston - New York 2013, s. 11. 


\section{ZARZĄDZANIE INFORMACJAMI JAKO ŹRÓDŁO PRZEWAGI KONKURENCYJNEJ ŁAŃCUCHA DOSTAW...}

Penc J., Zarządzanie dla przyszłości. Twórcze kierowanie firmą, Wydawnictwo Profesjonalnej Szkoły Biznesu, Kraków 1998.

Rutkowski I., Marketing jako źródło przewagi konkurencyjnej na rynku [w:] Marketing jako czynnik i instrument konkurencji, PWE, Warszawa 1997.

Urbanek G., Kompetencje a wartość przedsiębiorstwa, Wolters Kluwer, Warszawa 2011.

Big Data in Logistics. A DHL perspective on how to move beyond the hype, 2013, http://www.dhl.com/ content/dam/downloads/g0/about_us/innovation/CSI_Studie_BIG_DATA.pdf [14.03.2016].

Internet. Publiczne bazy danych i Big Data, red. G. Szpor, C.H. Beck, Warszawa 2014.

Osiaganie korzyści z Big Data: skup się na możliwościach, a nie na przeszkodach, SAP, 2014, http:// go.sap.com/poland/docs/download/2015/08/de20afbb-377c-0010-82c7-eda71af511fa.pdf [16.03.2016].

Przedsiębiorstwo wobec wspótczesnych wyzwań w procesie zarządzania, red. I. Hejduk, L. Ciborowski, Wydawnictwo Akademii Podlaskiej, Siedlce 2005.

The Diverse and Exploding Digital Universe, An IDC White Paper, http://www.ifap.ru/library/ book268.pdf [10.03.2016].

Trends and Strategies in Logistics and Supply Chain Management, BVL International, 2013, http:// picsbelgium.be/wp-content/uploads/2013/07/BVL_TrendsandStrategies_SCM _Logistics_2013_ pdf.pdf [14.03.2016].

Wprowadzenie do nauki o przedsiębiorstwie, red. M. Brzeziński, Difin, Warszawa 2007.

Zarzadzanie zasobami informacyjnymi w warunkach nowej gospodarki, red. R. Borowiecki, J. Czekaj, Difin, Warszawa 2010. 

Barbara Dunin-Suligostowska, Joanna Sowa

Politechnika Poznańska

Wydział Inżynierii Zarządzania

ul. Strzelecka 11, 60-965 Poznań

\section{Integracja łańcuchów dostaw poprzez wykorzystanie nowoczesnych technologii i systemów informatycznych}

\section{WPROWADZENIE}

W dzisiejszym świecie dąży się do jak najlepszej współpracy między ogniwami w łańcuchu dostaw w celu osiągnięcia przewagi konkurencyjnej na rynku. Zjawisko integracji wewnątrz łańcuchów oraz pomiędzy nimi jest coraz częściej obserwowane. Do osiągnięcia celu służą różnorodne technologie i systemy informatyczne. Narzędzia te ułatwiają kontakt między ogniwami oraz dają możliwość szybkiego przepływu informacji. Dzięki nim możliwa jest efektywna współpraca łańcuchów dostaw.

Obecnie jedynym sposobem na uzyskanie integracji w łańcuchach dostaw staje się wykorzystanie możliwości, jakie oferują technologie i systemy informatyczne. Dostarczaniem tego typu usług zajmuje się coraz więcej firm, a ich propozycje generują wiele usprawnień $\mathrm{w}$ funkcjonowaniu przedsiębiorstw logistycznych. Dla nich jest to szansa na zmniejszenie kosztów działania, zoptymalizowanie posiadanych zasobów oraz zapewnienie klientom wymaganego przez nich poziomu obsługi.

Celem referatu jest przedstawienie charakterystyki wybranych technologii i systemów informatycznych oraz pokazanie, jaki wpływ mają na integrację łańcuchów dostaw.

\subsection{Przeslanki I POdstaWy integracji lańCuChów dostaw}

Rozpoczynając rozważania nad kwestią integracji łańcuchów dostaw, należy zdefiniować, czym jest łańcuch dostaw. J. Witkowski stwierdza, że „łańcuch dostaw to współdziałające w różnych obszarach funkcjonalnych firmy wydobywcze, produkcyjne, handlowe, usługowe oraz ich klienci, między którymi przepływają strumienie produktów, informacji i środków finansowych"1. Powstanie takiego łańcucha było koniecznością w trakcie rozwoju gospodarki i doprowadziło do

\footnotetext{
${ }^{1}$ J. Witkowski, Zarządzanie łańcuchem dostaw: koncepcje, procedury, doświadczenia, PWE, Warszawa 2010, s. 19.
} 
utworzenia sieci relacji między przedsiębiorstwami. Wymagane stało się dbanie o odpowiednie zarządzanie takim łańcuchem oraz organizowanie sprawnego przepływu towarów, danych i informacji między jego ogniwami. Tradycyjnie zorganizowane łańcuchy dostaw charakteryzowały się tym, że ograniczone lub niemożliwe było prowadzenie wspólnej, jednolitej polityki planowania.Zmiany zostały spowodowane przez kilka czynników. Najważniejszym z nich była rosnąca świadomość oraz wymagania klientów. Zachowania te spowodowały powstanie nowych wyzwań przed przedsiębiorstwami oraz uczestnikami rynku. W celu ograniczenia kosztów oraz podwyższenia poziomu obsługi klienta, ogniwa łańcucha dostaw zaczęły ze sobą współpracować. Rozpoczęła się integracja w celu dążenia do wspólnie postawionych celów. Podstawowym czynnikiem, który powoduje wzrost sprawności łańcucha, jest przepływ informacji. Wykorzystanie technologii i systemów informatycznych wspomaga zarządzanie łańcuchami dostaw ${ }^{2}$.

Zarządzanie łańcuchem dostaw według M. Christophera jest „zarządzaniem stosunkami z dostawcami i odbiorcami oraz klientami w celu dostarczenia najwyższej wartości dla klienta po najniższych kosztach dla całego łańcucha dostaw"3. Analizując wyżej opisane zagadnienie zauważyć można, że odnosi się ono do wszystkich ogniw w łańcuchu dostaw. Nie wolno pomijać żadnego z nich, gdyż każdy element ma wpływ na poprawne funkcjonowanie całości. Dzięki odpowiedniemu zarządzaniu możliwe jest np. obniżenie kosztów, zwiększenie efektywności oraz skrócenie czasu realizacji zamówienia.

Przez pojęcie zintegrowanego łańcucha dostaw należy rozumieć planowanie, zarządzanie i koordynowanie działań wszystkich uczestników łańcucha dostaw, we wszystkich obszarach procesu logistycznego, w trakcie całego procesu tworzenia produktu - od planowania do dostarczenia ostatecznemu odbiorcy ${ }^{4}$.

Zintegrowane łańcuchy charakteryzuje zbiór atrybutów, które przesądzają o jego sprawności. Należy zaliczyć do nich:

- wykorzystywanie dokładnej informacji jako źródła działań decyzyjnych,

- traktowanie czasu przepływu jako miernika sprawności łańcucha i konsekwentne dążenie do jego skracania,

- wspólne identyfikowanie i eliminowanie barier na drodze przepływu dóbr i informacji,

- eliminowanie działań, które nie dodają wartości,

- zaspokajanie potrzeb ostatecznego klienta traktowane jako wspólny cel wszystkich współpracujących przedsiębiorstw.

\footnotetext{
${ }^{2}$ P. Piorunkiewicz, Systemy informatyczne w zarzadzaniu łańcuchem dostaw, Konferencja SWO 2004 w Katowicach, s. 575-576.

${ }^{3}$ S. Kot, M. Starostka - Patyk, D. Krzywda, Zarządzanie łańcuchami dostaw, Politechnika Częstochowska, Częstochowa 2009, s. 15.

${ }^{4}$ A. Łupicka - Szudrowicz, Zintegrowany łańcuch dostaw $w$ teorii i praktyce gospodarczej, Akademia Ekonomiczna w Poznaniu, Poznań 2004, s. 54.
} 
Cechami charakterystycznymi zintegrowanych łańcuchów dostaw są: długookresowy charakter związków, dzielenie się informacją i monitorowanie działań, koordynacja przepływów, wspólne planowanie, dzielenie się ryzykiem i korzyściami oraz bardziej efektywne dostarczanie produktów na rynek ${ }^{5}$.

\subsection{TECHNOLOGIE I SYSTEMY INFORMATYCZNE}

Technologie zarządzania łańcuchem dostaw to zespół narzędzi i sposobów postępowania $\mathrm{w}$ procesie realizacji przepływu dóbr i osób, a także w działaniach wspomagających ten proces ${ }^{6}$. Technologia informatyczna usprawnia realizację operacji wewnętrznych oraz współpracę między przedsiębiorstwami należącymi do łańcucha dostaw. Systemy informatyczne wykorzystywane przez firmy logistyczne opierają się na systemach baz danych, których zadaniem jest gromadzenie i przetwarzanie danych potrzebnych konkretnym ogniwom łańcuchów ${ }^{7}$. Informacje przechowywane w bazach danych powinny być dostępne i czytelne dla każdego uczestnika łańcucha dostaw w dowolnym momencie. Konieczne zatem staje się zastosowanie zintegrowanego systemu informatycznego, który umożliwi korzystanie $\mathrm{z}$ bazy danych niezależnie od toczących się procesów przetwarzania informacji przy jednoczesnej wymianie danych ${ }^{8}$.

Opisane technologie i systemy informatyczne wykorzystują systemy baz danych. Wprowadzenie tych technologii daje łańcuchom dostaw szansę na zwiększenie wymiany informacji między ogniwami oraz przyspieszenie procesu przepływu tych informacji.

\subsubsection{MRP I MRP II}

W przedsiębiorstwach bardzo często wykorzystywany jest system MRP I (Planowanie Zapotrzebowania Materiałowego). System MRP I składa się z ciągu logicznie ze sobą powiązanych procedur, reguł decyzyjnych i rejestrów, których celem jest przełożenie głównego harmonogramu produkcji na rozłożone w czasie zapotrzebowanie netto na zapasy i planowanie pokrycia tych potrzeb według poszczególnych pozycji.

System ten stosowany jest głównie w celu zapewnienia odpowiedniej ilości materiałów, części i produktów na potrzeby zaplanowanej produkcji i dostaw. Dzięki odpowiedniemu planowaniu działań produkcyjnych, harmonogramów dostaw i zakupów, możliwe jest utrzymywanie optymalnego poziomu zapasów.

\footnotetext{
${ }^{5}$ E. Gajoszek, Narzędzia informatyczne wspierające innowacyjny łańcuch dostaw na przykładzie wdrożenia systemu ERP w międzynarodowej grupie firm, „Logistyka”, nr 2, 2011, s. 174.

${ }^{6}$ R. Barcik, M. Kubański, Technologie wspomagające zarządzanie łańcuchem dostaw, „Logistyka”, nr 4, 2011, s. 81.

${ }^{7}$ Ibidem.

${ }^{8}$ P. Piorunkiewicz, op. cit., s. 577.
} 
System informatyczny posiada szereg zalet. Najważniejszą z nich jest koordynacja zamówień materiałów we wszystkich miejscach systemu logistycznego. Główną wadą natomiast jest to, że niski poziom zapasów może powodować wzrost kosztów zamówień i transportu. Warto zastanowić się nad tym, czy lepiej jest utrzymywać więcej produktów w zapasie, czy może częściej je zamawiać. Koszty zamawiania często powodują, że zakup małych partii staje się nieopłacalny.

Oprócz MRP I występuje także MRP II (Planowanie Zasobów Wytwórczych). Stanowi rozszerzenie MRP I o implikacje w stosunku do zdolności produkcyjnych. System ten daje możliwość zintegrowania planowania finansowego z podstawową działalnością logistyczną oraz stanowi doskonałe narzędzie planistyczne, pozwalające na opisanie prawdopodobnych rezultatów wdrażania strategii logistycznych, produkcyjnych, marketingowych i finansowych. MRP II wykorzystuje się do planowania i zarządzania wszelkimi zasobami organizacji, przy czym wykracza on poza zwykłe planowanie zapasów i sterowanie produkcją, znajdując zastosowanie we wszystkich funkcjach planistycznych organizacji9.

Systemy MRP posiadają odniesienia do różnych ogniw łańcucha. $\mathrm{W}$ widoczny sposób odnoszą się do współpracy pomiędzy nimi.

\subsubsection{ERP (ANg. ENTerprise Resource Planning)}

Najczęściej wykorzystywanym systemem, który wspomaga działania zachodzące w łańcuchu dostaw jest ERP (System Planowania Zasobów Przedsiębiorstwa). Rozwój MRP I i II doprowadził do powstania ERP, określanego również jako MRP III. Jest to system odpowiedzialny za określanie potrzeb materiałowych oraz pełne wykorzystanie wszelkich zasobów firmy, planowania, produkcji i dystrybucji oraz natychmiastowego reagowania na wahania popytu przy uwzględnieniu aktualnych warunków i ograniczeń występujących na rynku ${ }^{10}$.

System klasy ERP stanowi zestaw modułów funkcjonalnych, zintegrowanych ze sobą, których zadaniem jest optymalizacja procesów biznesowych wewnątrz firmy oraz zachodzących w jej otoczeniu. Jest to możliwe dzięki narzędziom pozwalającym automatyzować wymianę danych w całym łańcuchu dostaw. System ten obejmuje takie obszary funkcjonowania przedsiębiorstwa, jak: obsługa klienta, produkcja, finanse oraz integracja łańcucha logistycznego.

System ERP posiada szereg zalet. Przede wszystkim obejmuje swoim zasięgiem całe przedsiębiorstwo, skupiając poszczególne działy w jednym systemie komputerowym. System oparty jest na informacji, umożliwia wielokrotne jej przetwarzanie bez negatywnych konsekwencji. Ponadto system tej klasy rejestruje procesy zachodzące $\mathrm{w}$ całym przedsiębiorstwie oraz ułatwia użytkownikom

\footnotetext{
${ }^{9}$ R. Barcik, M. Kubański, op. cit., s. 83-84.

${ }^{10}$ Ibidem, s. 84; T. Dudek, Nowe trendy w komputerowym wspomaganiu zarządzania łańcuchem dostaw, Konferencja BOS 2012 w Warszawie, s. 23.
} 
kontrolę nad ich przebiegiem. Dzięki swojej konstrukcji ERP pozwala na szybki dostęp do potrzebnych danych oraz sprawne zarządzanie informacjami firmy poprzez integrację poszczególnych działów ${ }^{11}$.

Sukces wdrożenia ERP uzależniony jest od dokładnego przeanalizowania łańcuchów procesów tworzenia, eliminacji czynności zbędnych oraz wdrożenia dokładnych procedur realizacji funkcji ${ }^{12}$.

ERP przygotowywany jest na szczeblu przedsiębiorstw produkcyjnych. Informacje opracowywane przez przedsiębiorstwo mogą być związane z łączącymi się dwoma łańcuchami. ERP w tym przypadku będzie łączył dane $\mathrm{z}$ dwóch różnych elementów wejściowych.

\subsubsection{DRP (ANg. Distribution ReQuirements Planning)}

W dystrybucji produktów znajduje zastsowanie system DRP. Jest to koncepcja funkcjonowania łańcucha dostaw w sferze dystrybucji. Opiera się na szacowaniu zapotrzebowania na wyroby finalne w końcowych ogniwach łańcucha dostaw (kontakt dystrybucja - klient) oraz zapotrzebowania czasowego i ilościowego na wszystkich szczeblach łańcucha dostaw ${ }^{13}$. System ten wykorzystuje te same zasady i techniki co MRP. W planowaniu zasobów dystrybucji analizuje się popyt na produkty, a następnie buduje się realistyczny i racjonalny, obejmujący cały system plan zamawiania produktów gotowych. W DRP opracowuje się harmonogram dystrybucji produktów z zakładów produkcyjnych i magazynów przedsiębiorstwa do miejsc, gdzie będą udostępniane klientom. Pozwala to na taki podział zapasów produktów, by w sposób optymalny zaspokoić potrzeby rynku ${ }^{14}$.

Najważniejszym zadaniem systemu DRP jest prognozowanie popytu niezależnego w ogniwach łańcuchów dostaw mających bezpośredni kontakt z klientem. System ten zajmuje się także opracowaniem harmonogramu uzupełniania zapasów we wszystkich szczeblach dystrybucji.

Zintegrowanie działania systemów DRP i MRP jest jednym z wyznaczników zintegrowanego łańcucha dostaw. Poprzez współpracę obu systemów możliwa jest szybka wymiana danych, co pozwala na bardziej dokładne ustalenie harmonogramów produkcji (w przypadku MRP) oraz lepsze zarządzanie zapasami i dostawami (w przypadku DRP) ${ }^{15}$.

Warto zwrócić uwagę, iż system DRP został rozwinięty w podobny sposób jak system MRP. Obecnie wyróżnić można także DRP II - Distribution Resource Planning. Oznacza ono planowanie zasobów dystrybucji. Zależność między systemami

\footnotetext{
${ }^{11} \mathrm{~K}$. Chwiesiuk, Analiza zastosowań systemów informatycznych klasy ERP w logistyce, „Logistyka”, nr 4, 2011, s. 164-166.

${ }^{12}$ R. Barcik, M. Kubański, op. cit., s. 84.

${ }^{13}$ I. Fechner, Zarządzanie łańcuchem dostaw, Wyższa Szkoła Logistyki, Poznań 2007, s. 80.

${ }^{14}$ R. Barcik, M. Kubański, op. cit.

${ }^{15}$ I. Fechner, op. cit., s. 80-81.
} 
DRP i DRP II jest zbliżona do tej między MRP i MRP II. System planowania zasobów dystrybucji stanowi rozszerzenie DRP o uwzględnienie dostępnych zdolności wykonawczych łańcucha dostaw. Dzięki niemu możliwe jest określenie zapotrzebowania na krytyczne zasoby (np. powierzchnię magazynową, środki transportu, siłę roboczą, kapitał) potrzebne do transportowania towarów w sieci dystrybucji i zestawienie tego zapotrzebowania $\mathrm{z}$ dostępnymi mocami łańcucha.

\subsubsection{EDI (ANG. EleCtronic DAta INTERChange)}

Bardzo ważny w codziennym funkcjonowaniu dostawców, przedsiębiorstw oraz dystrybutorów jest system elektronicznej wymiany danych EDI. Stanowi on często podstawę funkcjonowania współczesnych firm logistycznych i transportowych. System ten umożliwia elektroniczną wymianę dokumentów w oparciu o określone formaty i standardy. System EDI powstał z myślą o przekazywaniu danych bez konieczności ich ręcznego wprowadzania do komputerów. Poprawia współpracę nie tylko między uczestnikami danego łańcucha dostaw, ale także różnymi łańcuchami. Zastosowanie technologii pozwala ogniwom łańcuchów dostaw na bezpieczną komunikację i wirtualną wymianę dokumentów. System daje możliwość wykorzystania nowoczesnych rozwiązań, skrócenia czasu dostawy oraz szybkiego reagowania na zmienne potrzeby klientów ${ }^{16}$. Oprócz zalet, system posiada istotną wadę. Jest nią wysoki koszt wdrożenia, co sprawia, że jest powszechnie stosowany przede wszystkim w dużych przedsiębiorstwach. Do obsługi systemu konieczne jest posiadanie odpowiedniej infrastruktury informatycznej, która nie występuje we wszystkich firmach. Ogranicza to komunikację $\mathrm{z}$ dostawcami i odbiorcami ${ }^{17}$.

System EDI w ogromnym stopniu wpływa na ulepszenie współpracy między łańcuchami dostaw. Jak opisano powyżej, system ten posiada wiele istotnych zalet.

\subsubsection{RFID (ANG. RADIO FREQUENCY IDENTIFICATION)}

RFID to system automatycznej identyfikacji (AutoID), który ma możliwość rozpoznawania przedmiotów i gromadzenia danych na ich temat. Skanowanie produktów odbywa się zdalnie. Metoda ta wymaga zastosowania systemu komputerowego, w którym przechowywane są dane pobrane podczas skanowania.

System RFID posiada szereg zalet przemawiających za wprowadzeniem go do użytku. Umożliwia równoczesny odczyt wielu etykiet naraz, na odległość nawet kilku metrów. Etykiety RFID mają zastosowanie w sytuacjach utrudnionego dostępu do kodu (np. w ciasnych przestrzeniach), mogą mieć różny kształt i postać (zawieszka, nalepka, itp.). Użytkowanie tego systemu przyspiesza procesy

${ }^{16}$ T. Dudek, op. cit., s. 24.

${ }^{17}$ I. Fechner, op. cit., s. 142. 
skanowania dostaw w magazynach, ułatwia także monitorowanie sprzętu, np. pojazdów czy urządzeń oraz pozwala na ich szybką lokalizację. Dzięki temu RFID stosowane jest m.in. w programach śledzenia wysyłki od nadawcy do odbiorcy.

System posiada jednak kilka wad. Największą z nich jest wysoki koszt wprowadzenia go do użytku w przedsiębiorstwie. Razem z nim konieczne jest wprowadzenie systemu komputerowego, który będzie gromadził dane pobierane podczas skanowania. Niechęć do tej technologii powoduje również fakt, że sprzyja ona dokładnej i ciągłej kontroli oznakowanych towarów.

RFID w łańcuchach dostaw można zastosować na różne sposoby. Już wspomniane zostało przyspieszenie procesów przyjęcia dostawy do magazynu. Innym sposobem jest wykorzystanie danych zebranych podczas śledzenia przesyłek w celu optymalizacji tras transportowych. Dodatkowym atutem jest możliwość lokalizacji dostawy w celu kontroli przebiegu jazdy, np. nieprzewidzianych awarii środków transportu. Tagi stosowane w RFID mogą zostać także wyposażone w czujniki warunków panujących w otoczeniu (np. wilgoć, zapylenie), co może przyczynić się do poprawy warunków magazynowania i transportu dóbr wymagających szczególnej ochrony ${ }^{18}$.

System RFID ma znaczny wpływ na integrację łańcuchów dostaw. Daje możliwość przekazywania istotnych informacji pomiędzy ogniwami łańcuchów. RFID stosowany jest np. w identyfikacji oraz śledzeniu pojazdów z przesyłkami. W rzeczywistości może mieć miejsce transport od dostawcy występującego w pierwszym łańcuchu do producenta w kolejnym. Producent dzięki systemowi może kontrolować dostawę. Jest to jeden z możliwych wielu przykładów dotyczących integracji z wykorzystaniem RFID.

\subsection{WPEYW WYKORZYSTANIA TECHNOLOGII I SYSTEMÓW INFORMATYCZNYCH INTEGRACJĘ ŁAŃCUCHÓW DOSTAW}

Wykorzystanie technologii i systemów informatycznych w praktyce można zaobserwować m.in. w centrach dystrybucyjnych. Często tę rolę pełnią przedsiębiorstwa logistyczne zajmujące się magazynowaniem i transportem dóbr, które są zatrudniane przez większe przedsiębiorstwa produkcyjne jako pośrednicy w łańcuchach dostaw. Jedno centrum dystrybucyjne może obsługiwać wiele przedsiębiorstw, a tym samym łączy ono łańcuchy logistyczne różnych firm. Przykładem tego rozwiązania może być łańcuch dostaw firmy produkcyjnej, której łańcuch dostaw składa się z kilku ogniw. W tym opisie skupiono się na etapie zaopatrzenia produkcji firmy.

Logistyczny łańcuch dostaw firmy produkcyjnej na etapie zaopatrzenia produkcji składa się z kilku przedsiębiorstw pełniących rolę dostawców części (którzy

${ }^{18} \mathrm{~K}$. Kocot, O. Łazarowicz, P. Witowski, Wykorzystanie technologii RFID w budowaniu przewagi konkurencyjnej, „Logistyka”, nr 3, 2012, s. 1060. 
zapewne posiadają także swoich dostawców) oraz centrum dystrybucyjnego, w którym magazynowane są części potrzebne do produkcji. Łańcuch ten zaprezentowany jest na Rysunku 1.

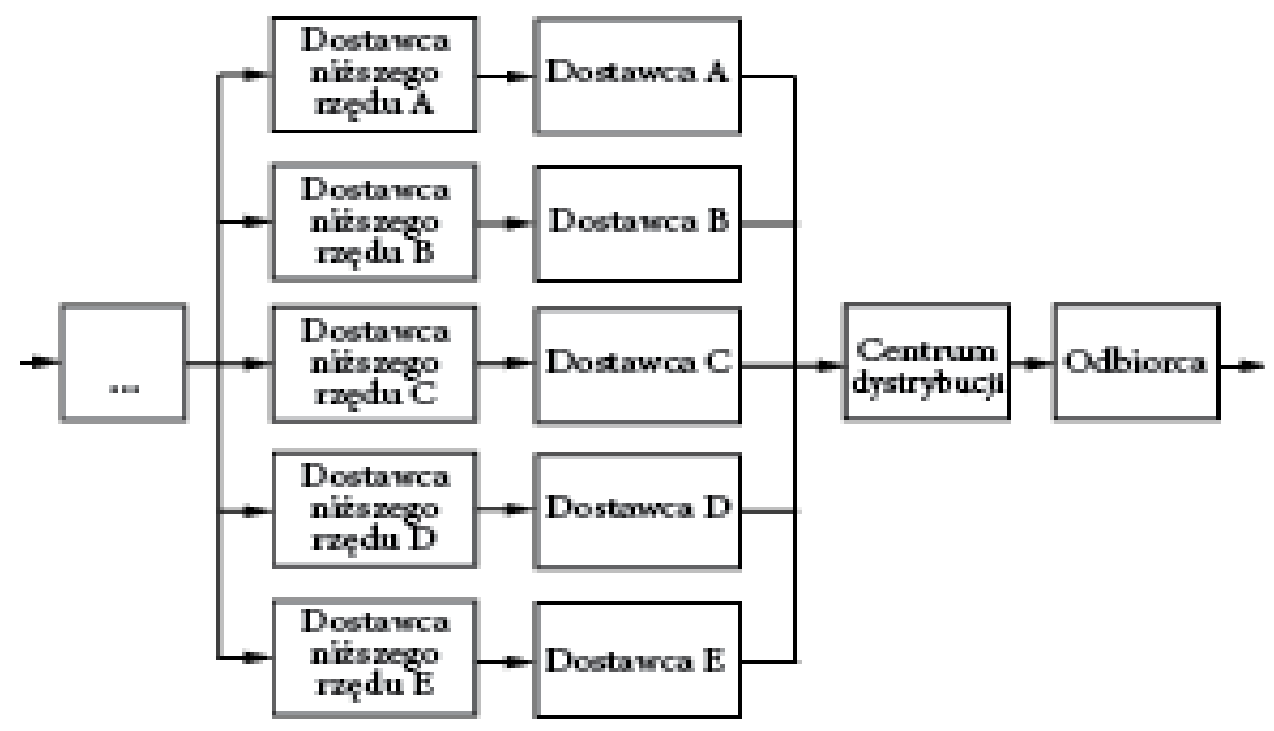

Rysunek 1. Schemat łańcucha dostaw firmy produkcyjnej

Źródło: opracowanie własne.

W analizowanym przykładzie dochodzi do integracji ogniw łańcuchów za pomocą sytemów informatycznych. Główne przedsiębiorstwo - odbiorca, posiada system ERP, za pomocą którego ustala harmonogram produkcyjny i zapotrzebowanie na części potrzebne do produkcji (wykorzystuje do tego także MRP). Dzięki stałej komunikacji systemowej z dostawcami składa ono zamówienia na brakujące podzespoły, które są przekazywane dostawcom. Oni z wykorzystaniem systemu DRP planują dostawy elementów. Są one realizowane za pośrednictwem centrum dystrybucyjnego, do którego transportowane są podzespoły pochodzące od różnych dostawców.

Działanie centrum oparte jest na systemie ERP, integrującym działania magazynu centrum (wykorzystuje on system WMS) oraz działu transportowego, który uczestniczy w transporcie dóbr. Do jednego centrum dystrybucyjnego przekazywane są dostawy pochodzące od różnych dostawców oraz wydawane są transporty dóbr do jednego odbiorcy, powstałe w wyniku połączenia dostaw kilku dostawców.

Wykorzystanie centrum dystrybucyjnego umożliwia firmie produkcyjnej oszczędności pracy, ponieważ przejmuje ono część obowiązków firmy wiązanych z przyjmowaniem dostaw od różnych dostawców. Dostawy te trafiają do 
magazynu centrum dystrybucyjnego, skąd dostarczane są jako jeden transport do odbiorcy. Działanie tego łańcucha oparte jest na systemach informatycznych (w szczególności ERP, DRP i WMS, ale również systemach identyfikacji towaru), umożliwiających szybki kontakt, sprawną komunikację pomiędzy ogniwami oraz współpracę w zakresie dostaw towaru.

\section{Podsumowanie}

Firmy produkcyjne oraz dystrybucyjne bez technologii i systemów informatycznych, elektronicznej wymiany danych mogą napotkać problemy $\mathrm{w}$ prawidłowym funkcjonowaniu w łańcuchu dostaw. W obecnych czasach dąży się do wprowadzania coraz nowszych i bardziej rozwiniętych systemów, które mogłyby ulepszyć pracę przedsiębiorstw oraz zwiększyć ich efektywność. Pozwala to na płynniejszą komunikację między ogniwami łańcucha i szybką reakcję na potrzeby rynku.

$\mathrm{Na}$ podstawie zaprezentowanych informacji można wnioskować, że zacieśnianie relacji między ogniwami łańcuchów dostaw oraz integracja łańcuchów dostaw (partnerstwo) polepsza ich funkcjonowanie, pozwalając im osiągać większe zyski, usprawniać przebieg procesów logistycznych, produkcyjnych oraz komunikacyjnych oraz rozwijać się w oparciu o nowoczesne systemy informatyczne. Integracja pozwala na osiągnięcie tzw. efektu synergicznego, czyli dodatkowych korzyści, które nie powstałyby, gdyby jego uczestnicy działali $\mathrm{w}$ rozproszeniu. Zastosowanie technologii wymienionych $\mathrm{w}$ rozdziale umożliwia dokonanie tych zmian.

\section{BibLIOGRAFIA}

Barcik R, Kubański M., Technologie wspomagające zarządzanie łańcuchem dostaw, „Logistyka”, nr 4, 2011.

Chwiesiuk K., Analiza zastosowań systemów informatycznych klasy ERP w logistyce, „Logistyka”, nr 4, 2011.

Dudek T., Nowe trendy w komputerowym wspomaganiu zarządzania łańcuchem dostaw, Konferencja BOS 2012 w Warszawie.

Fechner I., Zarządzanie łańcuchem dostaw, Wyższa Szkoła Logistyki, Poznań 2007.

Gajoszek E., Narzędzia informatyczne wspierające innowacyjny łańcuch dostaw na przykładzie wdrożenia systemu ERP w międzynarodowej grupie firm, „Logistyka”, $\mathrm{nr}$ 2, 2011.

Kocot K., Łazarowicz O., Witowski P., Wykorzystanie technologii RFID w budowaniu przewagi konkurencyjnej, „Logistyka”, nr 3, 2012.

Kot S., Starostka-Patyk M., Krzywda D., Zarządzanie łańcuchami dostaw, Politechnika Częstochowska, Częstochowa 2009.

Łupicka-Szudrowicz A., Zintegrowany łańcuch dostaw w teorii i praktyce gospodarczej, Akademia Ekonomiczna w Poznaniu, Poznań 2004.

Piorunkiewicz P., Systemy informatyczne w zarządzaniu łańcuchem dostaw, Konferencja SWO 2004 w Katowicach. 


\section{Barbara Dunin-Suligostowska, Joanna Sowa}

Witkowski J., Zarządzanie łańcuchem dostaw: koncepcje, procedury, doświadczenia, PWE, Warszawa 2010. 
Mgr inż. Mateusz Dziechciarz

Uniwersytet Szczeciński

Wydział Zarządzania i Ekonomiki Usług

ul. Cukrowa 8, 71-004 Szczecin

\section{Dobre praktyki w obsłudze ładunków skonteneryzowanych w Porcie Szczecin}

\section{WPROWADZENIE}

Współczesny rynek stawia przed uczestnikami łańcucha dostaw coraz większe wymagania. Oczekiwania względem jakości oferowanych usług sprawiają, że efektywny przepływ dóbr przez łańcuch dostaw stał się nie tylko warunkiem, ale i standardem. Procesy magazynowania, przeładunku, transportu i kontroli stają się bardziej złożone tak, aby zapewnić maksymalny poziom bezpieczeństwa ładunku. $\mathrm{Z}$ drugiej strony presja czasu oraz konkurencyjny rynek stawiają operatorom logistycznym wysokie wymagania utrzymania swobodnego przepływu ładunków. Rozwój taboru transportowego postępuje w kierunku zwiększania ładowności środków transportu, przy zachowaniu parametrów bezpieczeństwa. Najnowocześniejsze kontenerowce klasy Triple E są w stanie przyjąć na pokład ponad 19 tys. TEU.

Jednym z najważniejszych elementów łańcuchów dostaw we współczesnej gospodarce są porty morskie. $Z$ racji charakteru prowadzonej działalności i położenia przy akwenach wodnych, porty morskie są miejscem kumulacji kilku gałęzi transportu: morskiego i śródlądowego od strony wody oraz samochodowego i kolejowego po stronie lądowej. Przed współczesnym portem morskim stawiane są coraz większe wymagania. Otoczenie portu sprawia, że jest on koncentratorem wielu czynności związanych z ładunkiem, począwszy od przeładunku i składowania, poprzez usługi agencyjne, kontrolne i spedycyjne, obsługę celno-podatkową oraz dodatkowe usługi uszlachetniania i logistyczne ${ }^{1}$.

Celem rozdziału jest przedstawienie praktycznych rozwiązań prowadzących do usprawnienia przepływu jednostek skonteneryzowanych w ramach łańcuchów dostaw. Analiza została oparta o obserwacje funkcjonowania systemu CMS Autostore dla terminalu kontenerowego w Porcie Szczecin oraz opinie przedstawicieli instytucji działających w bezpośrednim otoczeniu Portu. Do opracowania rozdziału wykorzystano analizę oceny realizacji pakietu Porty 24.

\footnotetext{
${ }^{1}$ A. Grzelakowski, M. Matczak, Współczesne porty morskie. Funkcjonowanie i rozwój, Wydawnictwo Akademii Morskiej w Gdyni, Gdynia 2012, s. 77.
} 


\subsection{Charakterystyka Portu Szczecin}

Port, według definicji przyjętej przez Radę Unii Europejskiej, jest to „miejsce posiadające urządzenia dla statków handlowych, do cumowania oraz ładowania lub rozładowywania ładunku albo do wysadzenia lub zabrania pasażerów na lub ze statków"2. Według szerszej definicji zakres usług portów morskich wykracza poza wyznaczone przez Radę działania, koncentrując się nie tylko na przeładunkach i składowaniu. Port morski to także koncentrator różnorodnej działalności gospodarczej, związanej pośrednio lub bezpośrednio z łańcuchami logistycznymi, funkcjonujący w systemie globalnego transportu jako część lądowo-morskiego łańcucha transportowego ${ }^{3}$. Działania nowoczesnych portów morskich skupiają się na świadczeniu wszelkiego rodzaju ułatwień dla przedsiębiorców. Skala i zakres tych działań obejmują pełen zakres usług transportowych, logistycznych, agencyjnych oraz spedycyjnych, mających ułatwić $i$ usprawnić efektywne przemieszczenie ładunku ogniwa w łańcuchu dostaw, jakim jest port morski4.

Zgodnie z „Ustawą o portach morskich i przystaniach” na terenie Polski funkcjonują cztery porty morskie o podstawowym znaczeniu dla gospodarki narodowej (w Gdańsku, Gdyni, Szczecinie i Świnoujścius). Wiodącym polskim portem morskim jest Port w Gdańsku, którego procentowy udział w obrotach ładunkowych w latach 2006-2013 wahał się w granicach od 35\% do 44\% globalnego udziału w przeładunkach polskich portów morskich ${ }^{6}$.

Port morski w Szczecinie współtworzy wraz z portem Świnoujście jeden $\mathrm{z}$ największych zespołów portowych $\mathrm{w}$ rejonie Morza Bałtyckiego. Zespół portowy jest położony na najkrótszej drodze łączącej południową i środkową Europę ze Skandynawią, a także Europę Zachodnią z Finlandią, Rosją, Litwą oraz Estonią.

Port w Szczecinie ${ }^{7}$, zajmujący czwarte miejsce pod względem udziału w obrotach ładunkowych wśród polskich portów, z udziałem w latach 2006-2013 od 13,9\% do $15,9 \%$ globalnych przeładunków w polskich portach morskich, jest położony $68 \mathrm{~km}$ na południe od linii brzegowej Morza Bałtyckiego i jest najdalej wysuniętym w głąb kraju polskim portem. Obecnie możliwości nawigacyjne toru wodnego Szczecin - Świnoujście sprawiają, że Port Szczecin jest dostępny dla mniejszych statków o zanurzeniu do $9,15 \mathrm{~m}$, co w znacznym stopniu ogranicza

\footnotetext{
${ }^{2}$ Dyrektywa Rady 95/64/WE z dnia 8 grudnia 1995 r. w sprawie sprawozdań statystycznych w odniesieniu do przewozu rzeczy i osób drogą morską, art. 2, ust. 3.

${ }^{3}$ T. E. Notteboom, Spatial and functional integration of container port systems and hinterland networks in Europe, Land access to sea port, Economic Research Centre, European Conference of Minister of Transport, Paris 1998, s. 9.

${ }^{4}$ A. Grzelakowski, M. Matczak, op. cit., s. 19.

${ }^{5}$ Ustawa z dnia 20 grudnia 1996 r. o portach i przystaniach morskich, art. 2, ust. 3.

${ }^{6}$ Rocznik statystyczny gospodarki morskiej 2014, Główny Urząd Statystyczny, s. 19.

${ }^{7}$ Szerokość $53^{\circ} 25^{\prime} \mathrm{N}$, długość $14^{\circ} 32^{\prime} \mathrm{E}$.
} 
konkurowanie Szczecina z bardziej dostępnymi portami rejonu Morza Bałtyckie$\mathrm{go}^{8}$. Port Szczecin stanowi zaplecze dla odbiorców znajdujących się w centralnej i południowej części kraju (m.in.: Górny i Dolny Śląsk, Wielkopolska, Małopolska). Ponadto regularnie rozwijana sieć połączeń drogowych (droga ekspresowa S3 oraz autostrada A6) sprawia, że Szczecin jest ważnym portem przeładunkowym dla odbiorców z Niemiec, Czech, Słowacji oraz z państw Europy Południowo-Zachodniej (Francja, Austria, Włochy) 9

Zakres usług świadczonych przez przedsiębiorstwa przeładunkowe działające w ramach portu w Szczecnie sprawia, że jest on portem uniwersalnym. Dzieli się na dwa obszary: rejon przeładunków masowych, gdzie dominującą rolę spełnia przeładunek i składowanie węgla, rudy, nawozów, koksu oraz zboża oraz rejon ładunków drobnicowych, gdzie oprócz drobnicy konwencjonalnej (palety, bloki granitowe, metale kolorowe, celuloza i papier) przeładowywane są ładunki skonteneryzowane, ro-ro oraz ponadgabarytowe. Ponadto port w Szczecinie oferuje możliwość przeładunku materiałów płynnych oraz niebezpiecznych.

W ramach Zespołu Portów Szczecin i Świnoujście jednostki skonteneryzowane są obsługiwane przez dwóch operatorów. W Świnoujściu jest to OT Port Świnoujście Sp. z o.o., natomiast w Szczecinie spółka DB Port Szczecin Sp. z o.o. W Porcie Szczecin kontenery są składowane i przeładowywane na dwóch nabrzeżach: czeskim o długości 410 m o maksymalnym zanurzeniu $9,15 \mathrm{~m}$ oraz na nabrzeżu fińskim o długości 300 m o maksymalnym zanurzeniu $9,15 \mathrm{~m}$. Obecna zdolność przeładunkowa terminalu kontenerowego w Szczecinie wynosi 120 tys. TEU rocznie. W ramach inwestycji współfinansowanej ze środków Unii Europejskiej w ramach Programu Operacyjnego Infrastruktura i Środowisko trwa rozbudowa terminalu kontenerowego położonego na Ostrowie Grabowskim (nabrzeże fińskie) ${ }^{10}$.

\subsection{Single Window ORAZ ONE STOP SHOP DLA Terminalu Kontenerowego w Porcie Szczecin}

Przepływ kontenerów w terminalu odbywa się w relacjach: pośredniej i bezpośredniej. W ramach relacji pośredniej kontenery są przeładowywane ze środka transportu na plac składowy, a następnie na środek transportu. Relacja bezpośrednia oznacza przeładunek z pominięciem złożenia kontenera na placu. W praktyce najczęściej realizowaną formą przeładunku kontenera przez terminal jest relacja pośrednia, uwzględniająca złożenie na terminalu. Ruch kontenerów w porcie polega przede wszystkim na czynnościach manipulacyjnych związanych z fizycznym

\footnotetext{
${ }^{8}$ Obecnie trwają prace mające na celu zwiększenie głębokości eksploatacyjnej toru wodnego Szczecin

- Świnoujście oraz basenów i nabrzeży portowych w Szczecinie do głębokości 12,5 m.

${ }_{9}^{9}$ Zarząd Morskich Portów Szczecin i Świnoujście, http://www.port.szczecin.pl/pl/porty/lokalizacja [29.12.2015].

${ }^{10}$ Zarząd Morskich Portów Szczecin i Świnoujście, http://www.port.szczecin.pl/pl/spolka/strategia-i -rozw\%C3\%B3j/rozw\%C3\%B3j/projekty-unijne-w-ramach-poii\%C5\%9A [04.01.2016].
} 
przemieszczeniem $\mathrm{w}$ poszczególnych relacjach. Za organizację przemieszczenia kontenerów po terminalu odpowiadają nie tylko pracownicy terminalowi, ale też podmioty znajdujące się $\mathrm{w}$ bezpośrednim otoczeniu terminalu kontenerowego, których działania mają na celu efektywny ruch kontenerów. Należą do nich: przedsiębiorstwa spedycyjne, agencyjne, kontrolne i ubezpieczeniowe, armatorzy morscy, urzędy celne oraz organy kontroli granicznej (Rysunek 1).

We wcześniejszych latach organizacja obsługi kontenerów na terminalu kontenerowym w Porcie Szczecin odbywała się poprzez obieg papierowych dokumentów. Kontenery przemieszczane poza obszar Unii Europejskiej lub przywożone $\mathrm{z}$ krajów trzecich dodatkowo wymagają kontroli odpowiednich służb, co wymagało adnotacji na drukowanych zleceniach A/C i B ze strony organów kontrolnych - wydłużało to czas potrzebny do zwolnienia kontenera. Na rozciągniętą w czasie i generującą koszty obsługę w porcie wpływały także m.in.: brak wspólnej platformy wymiany danych na temat ładunków, niekompatybilność pracy inspekcji kontrolnych oraz zróżnicowanie wewnętrznych procedur instytucji kontrolujących, ich nierównomierny rozwój w sferze zinformatyzowania. Wpływało to na wydłużenie procedur związanych ze zwolnieniem kontenera. Miały miejsce sytuacje, gdy

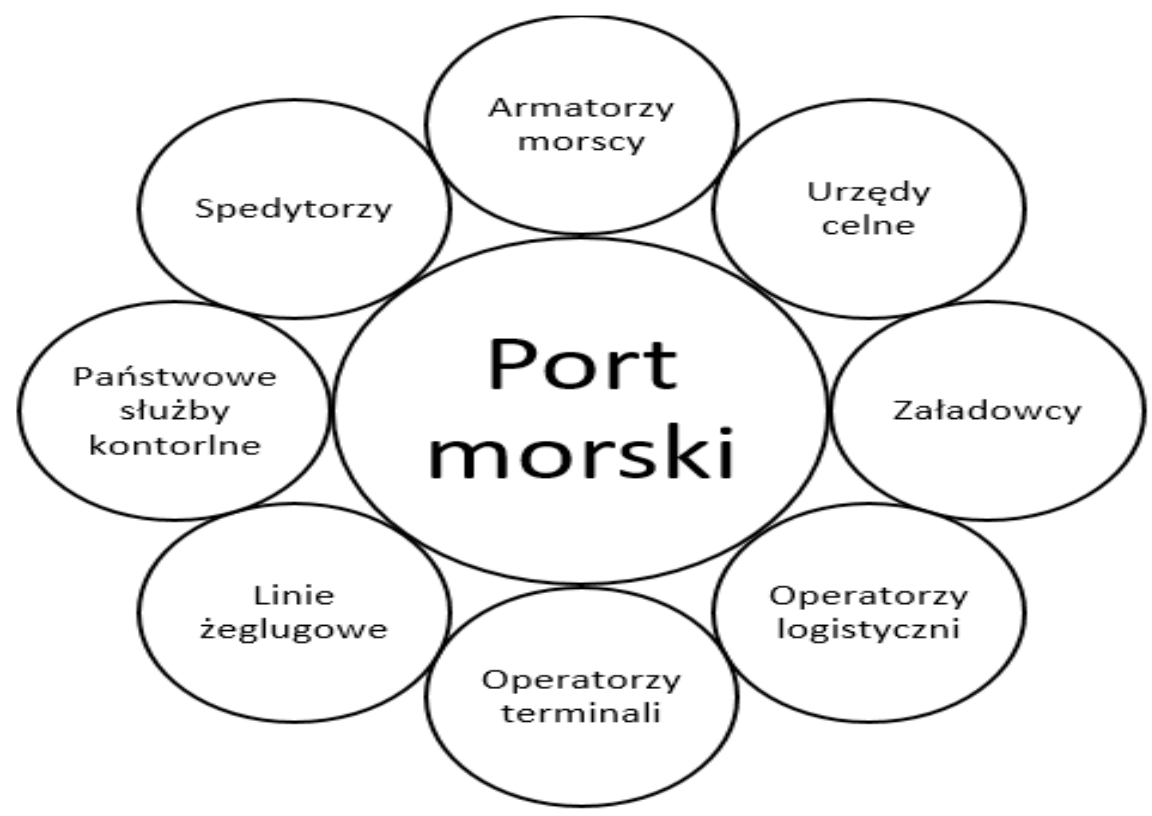

Rysunek 1. Otoczenie portu morskiego

Źródło: D. Bernacki, Rozwój portu morskiego w świetle relacji podmiotów zaangażowanych $w$ obsługe morsko-lądowych łańcuchów dostaw [w:] Polskie porty morskie $w$ procesie przemian europejskiego rynku usług portowych, red. H. Salmonowicz, Wyższa Szkoła Bankowa w Poznaniu, Wydział Ekonomiczny w Szczecinie, 2014, s. 15. 
postanowienie dotyczące wyników inspekcji kontenera było wydawane w kolejnym dniu roboczym ${ }^{11}$.

Wraz ze zwiększającym się wolumenem ładunków wzrastały także wymagania odbiorców w zakresie efektywnej i jak najkrótszej obsługi kontenerów w porcie. Potrzeba sprostania wymaganiom stawianym przez uczestników łańcucha dostaw zaowocowała wdrożeniem w polskich portach pakietu "Porty 24” realizującego założenia Ustawy z dnia 27 listopada 2014 roku o ułatwieniu wykonywania działalności gospodarczej, określanej jako „Pakiet morski”, dążącej do „poprawy organizacji obsługi ładunków w polskich portach morskich poprzez skrócenie czasu kontroli przeprowadzanych przez wszystkie działające tam służby” ${ }^{12}$. Ideą pakietu „Porty 24” jest skrócenie czasu obsługi ładunków w portach oraz taka organizacja kontroli, aby czas płynący od momentu zgłoszenia ładunku do inspekcji do ostatecznego zwolnienia w gestię odbiorcy był nie dłuższy niż $24 \mathrm{~h}$.

Wdrożenie pakietu „Porty 24” w Porcie Szczecin nie wiązało się z dodatkowymi nakładami pracy ze strony użytkowników portowych. Pakiet został zaadoptowany do wcześniej funkcjonujących rozwiązań stosowanych na szczecińskim terminalu kontenerowym: terminalowego single window oraz one stop shop. Dodatkowo wzmocniona została sfera elektronicznej komunikacji pomiędzy Służbą Celną, operatorem portowym, klientami i inspekcjami granicznymi ${ }^{13}$.

Zgodnie $\mathrm{z}$ ideą single window obsługa ewidencyjna kontenerów na terminalu kontenerowym DB Port Szczecin odbywa się z poziomu systemu komputerowego. Jest to system typu Port Community System (PCS) spełniający funkcję elektronicznej platformy, skupiającej w jednym miejscu uprawnione instytucje i organizacje, które mogą podejmować działania w ramach jednej branży, w tym przypadku, wspólnoty portowej ${ }^{14}$. Dla portu Szczecin funkcję systemu PCS spełnia platforma Container Management System Autostore (CMS).

Dzięki wdrożeniu systemu CMS Autostore użytkownik po zalogowaniu się do systemu otrzymuje niezbędne informacje dotyczące interesującego go kontenera np. jego aktualny status, liczbę i rodzaj założonych plomb, ewentualne uszkodzenia, informacje o blokadzie celnej oraz plan załadunku i nazwę statku w przypadku eksportu kontenera. Przykładowy widok ekranu z charakterystyką kontenera został przedstawiony na Rysunku 2. Ponadto system umożliwia przygotowanie oraz przesłanie w formie elektronicznej awizacji załadunku pojazdu oraz elektronicznej wersji zleceń $\mathrm{A} / \mathrm{C}$ na podjęcie i B na złożenie kontenera, eliminując konieczność ich dostarczenia w formie papierowej (Rysunek 3). Na wniosek Oddziału Celnego

${ }^{11}$ Raport z wykonania koordynacji kontroli w ramach Pakietu "Porty 24” za okres od dnia 01.01.2015 r. do 31.03.2015 r., Służba Celna, Ministerstwo Finansów, s. 5.

${ }^{12}$ Ocena realizacji instytucji „Porty 24” w Izbie Celnej w Szczecinie, „Wiadomości celne”, Ministerstwo Finansów, nr 3-4, Warszawa 2015, s. 13.

${ }^{13}$ R. Florczyk, Wdrożenie pakietu portowego, „Namiary na morze i handel”, nr 5, Wydawnictwo Promare, Szczecin 2015, s.10.

${ }^{14}$ International Port Community System Association, http://www.epcsa.eu/pcs [03.01.2016]. 
Łasztownia w Szczecinie, system CMS Autostore został udostępniony granicznym inspekcjom kontrolnym, dzięki czemu po dokonaniu czynności kontrolnych kontenera oraz wydaniu postanowienia dotyczącego dalszego postępowania, wszelkie

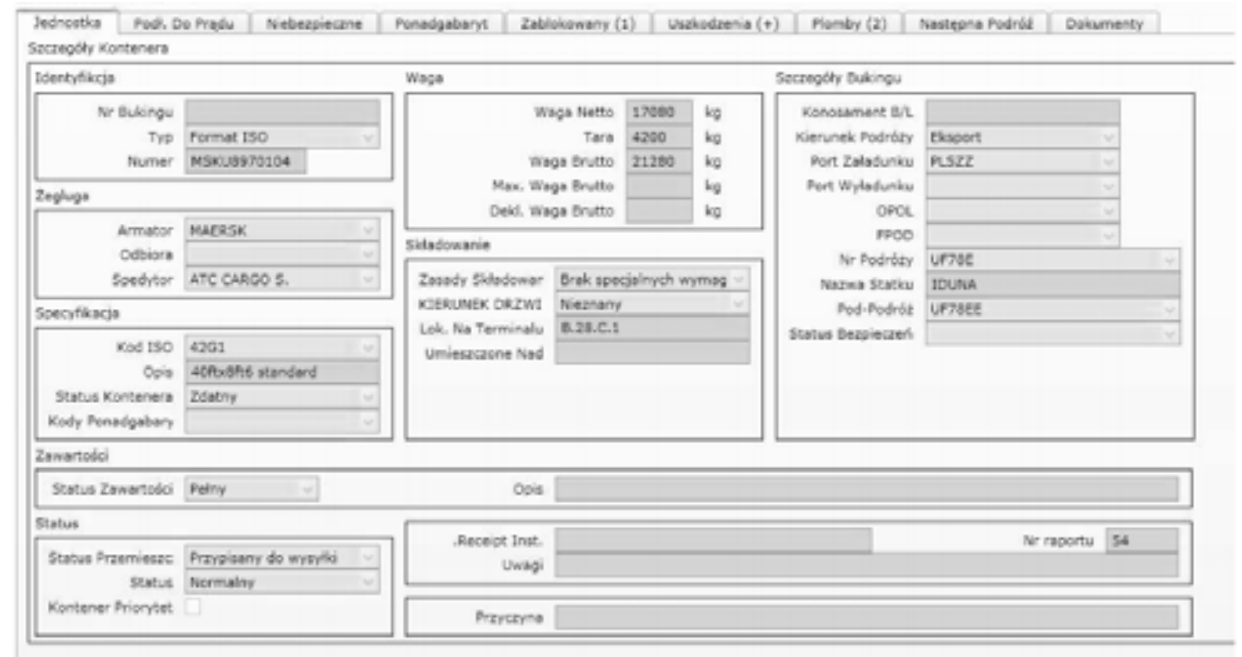

Rysunek 2. Okno szczegółowych informacji dotyczących kontenera w systemie CMS Autostore

Źródło: DB Port, http://dbport.eu/ [02.01.2016].

adnotacje mogą być dokonywane on-line bezpośrednio w systemie, wyprzedzając standardowy obieg dokumentów papierowych. Dzięki temu wyniki inspekcji są widoczne natychmiast po wprowadzeniu do systemu przez wszystkie zainteresowane strony, co umożliwia dalsze działania związane $\mathrm{z}$ dokonaniem zgłoszenia celnego kontenera, a w dalszej perspektywie jego wywóz do ostatecznego odbiorcy ${ }^{15}$.

Kolejnym udogodnieniem, usprawniającym ruch kontenerów na terminalu kontenerowym w Szczecinie, w ramach łańcucha dostaw, jest formuła one stop shop. Działania w ramach one stop shop polegają na dokonywaniu wszystkich inspekcji wymaganych przy wywozie i przywozie towarów w kontenerach w jednym miejscu i w jednym czasie. Obsługa kontenera, oprócz zwyczajowego udziału operatora i spedytora, niejednokrotnie wymaga obecności służb kontroli granicznej. $\mathrm{Z}$ uwagi na globalny charakter terminalu kontenerowego, w którym większość jednostek jest przeznaczona do wywozu poza teren Unii Europejskiej lub transport w głąb Polski, po uprzednim dostarczeniu z krajów trzecich, obecność państwowych służb kontrolnych jest niezbędna.

${ }^{15}$ R. Florczyk, Autostrada celna, „Namiary na morze i handel”, nr 23, Wydawnictwo Promare, Szczecin 2014, s. 14. 


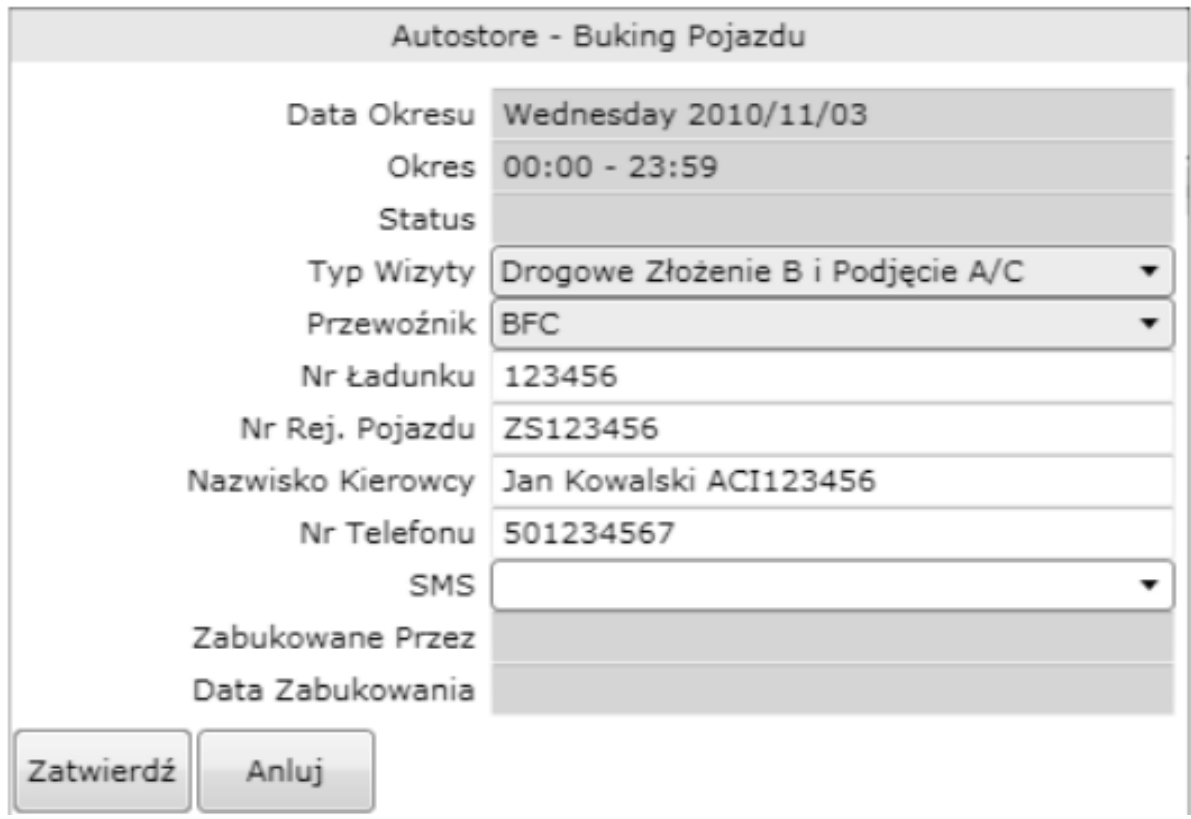

Rysunek 3. Zlecenie bukingu dla pojazdu na terminalu kontenerowym Źródło: Ibidem.

Zgodnie $\mathrm{z}$ ideą one stop shop po otrzymaniu zgody Urzędu Celnego na podstawienie kontenera do kontroli i jego przewiezienie przez operatora w wyznaczony punkt, przeprowadzane są inspekcje wszystkich granicznych służb kontrolnych oraz Urzędu Celnego w jednym czasie i miejscu. W Porcie Szczecińskim kontrole one stop shop przeprowadzane są we wskazanym punkcie, uwzględnionym w regulaminie terminalu kontenerowego. Pierwszym wskazanym miejscem jest placówka Granicznego Lekarza Weterynarii dla towarów wymagających przestrzegania wymogów sanitarnych. Dla towarów skonteneryzowanych, nie podlegających reżimom sanitarnym, miejscem właściwym dla przeprowadzania kontroli w ramach one stop shop jest obszar wskazany przez operatora terminalu, odpowiednio oznakowany i zabezpieczony, wolny od działań manipulacyjnych w trakcie trwania czynności kontrolnych. Po dokonaniu inspekcji wyniki kontroli są publikowane za pomocą systemu CMS Autostore. Zwyczajowo przyjętą godziną przeprowadzania inspekcji jest 9:00. Takie zorganizowanie placu na terminalu daje możliwość dokonania dalszych czynności manipulacyjnych oraz zgłoszenia celnego jeszcze podczas trwania tej samej zmiany ${ }^{16}$. Rysunek 4 przedstawia uproszczony schemat przebiegu komunikatów podczas inspekcji kontenera na szczecińskim terminalu kontenerowym.

${ }^{16}$ R. Florczyk, op. cit., s. 10. 


\section{Urząd celny-zgoda na przewóz do kontroli}

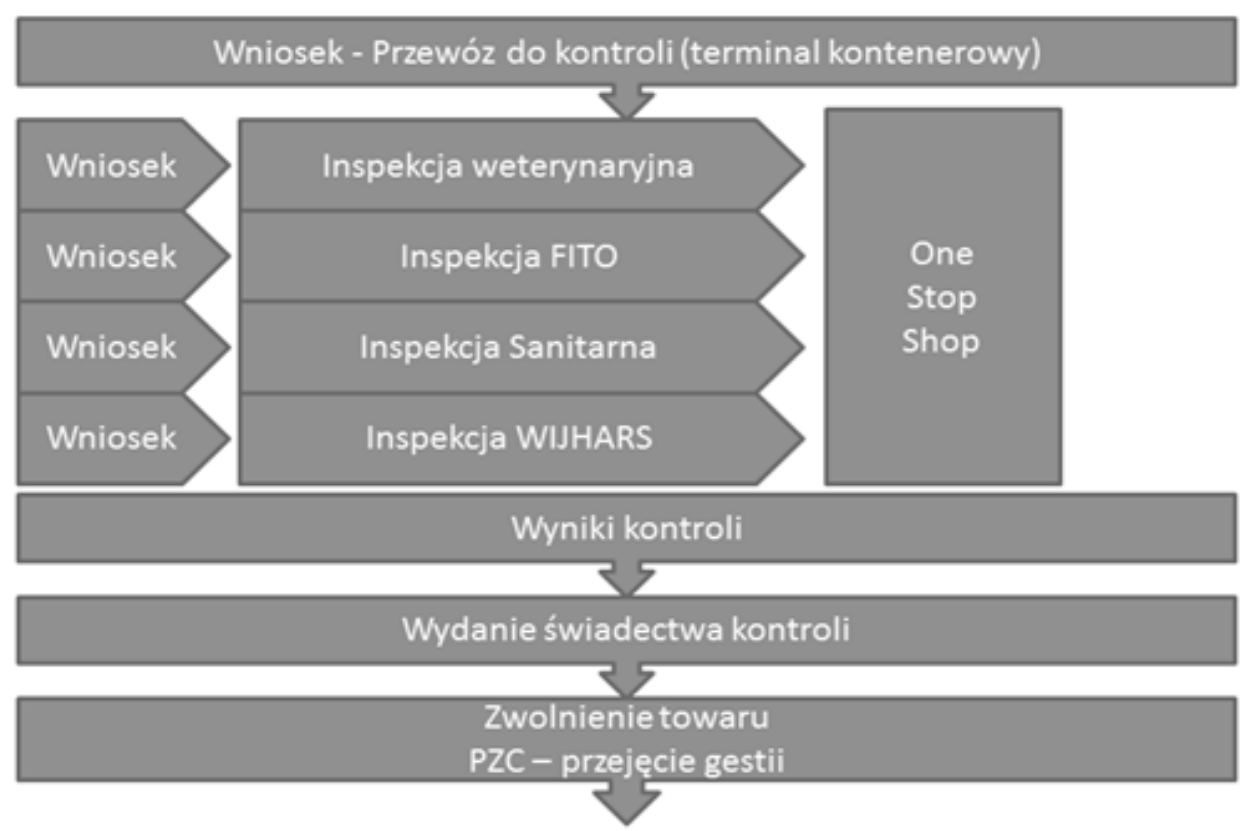

Rysunek 4. Schemat przebiegu komunikatów podczas obsługi kontenera na terminalu kontenerowym DB Port Szczecin

Źródło: R. Florczyk, Autostrada celna, „Namiary na morze i handel”, nr 23, Wydawnictwo Promare, Szczecin 2014, s. 15.

Zastosowanie terminalowego single window oraz idei one stop shop daje wymierne efekty w postaci oszczędności czasu potrzebnego na obsługę kontenerów w szczecińskim porcie. Uwzględniając czas poświęcany na inspekcję kontenera oraz pracę przy zgłoszeniu celnym wysyłanym z Oddziału Celnego Łasztowania (któremu podlega szczeciński terminal kontenerowy), efektywny czas kontroli kontenera wynosi średnio $3 \mathrm{~h}$ i $14 \mathrm{~min}$. Uzupełniając powyższą średnią o okres wymagany na złożenie przez dysponenta kontenera zgłoszenia celnego do organu celnego ( $6 \mathrm{~h} \mathrm{i} 37 \mathrm{~min}$. liczone od momentu wydania rozstrzygnięcia przez inspekcję), średni czas obsługi kontenera na terminalu kontenerowym w Porcie Szczecin od momentu podstawienia do kontroli do zwolnienia w systemie celnym do dyspozycji gestora ładunku to $6 \mathrm{~h}$ i $54 \mathrm{~min} .{ }^{17}$.

Kolejnym czynnikiem usprawniającym obsługę ładunków skonteneryzowanych na terminalu kontenerowym DB Port Szczecin jest rozwiązanie zaproponowane przez Urząd Celny w Szczecinie. Jak zostało nadmienione, większość kontenerów na terminalu jest obsługiwana z przeznaczeniem na wywóz poza Unię

${ }^{17}$ Op. cit., s. 14 . 
Europejską lub przewóz na teren kraju w imporcie spoza Unii. W przypadku importu kontenerów drogą morską przedsiębiorca ma 45 dni na nadanie statusu celnego towaru, jednak w przypadku konieczności szybkiego wywozu kontenera po złożeniu w porcie, przeznaczenie celne jest nadawane krótko po złożeniu kontenera na terminalu. Spiętrzenie zgłoszeń celnych powoduje stosowanie zasady first out - cleared. W tym przypadku w pierwszej kolejności przyjmowane są zgłoszenia celne na te towary, które mają być wyprowadzone z portu jako pierwsze, natomiast zgłoszenia na kontenery planowane do wywozu w późniejszym terminie są rozpatrywane $\mathrm{w}$ dalszej kolejności. Podstawą prawną takiego postępowania jest Obwieszczenie Ministra Finansów z dnia 14 grudnia 2012 roku w sprawie wykonywania kontroli przestrzegania przepisów prawa celnego oraz innych przepisów związanych z przywozem i wywozem towarów, w którym paragraf 7, punkt 6 głosi: „kontroli poza kolejnością można dokonać także w innych szczególnie uzasadnionych przypadkach". Interpretacja tego przepisu pozwala na zastosowanie reguły first out - cleared do najpilniejszych kontenerów.

\section{PODSUMOWANIE}

Port morski jest istotnym ogniwem w łańcuchu dostaw. Oprócz typowej działalności związanej z przeładunkiem i składowaniem odbywa się tam także szereg dodatkowych czynności związanych z ładunkiem. W bezpośrednim otoczeniu portu znajduje się wiele instytucji i przedsiębiorstw, dla których sprawny ruch kontenera po terminalu jest niezbędny dla zachowania efektywności łańcucha dostaw. Potrzebna do tego jest odpowiednia infrastruktura i suprastruktura, zarówno w sferze manipulacji kontenerów (urządzenia przeładunkowe, place składowe), jak i ich ewidencji (systemy komputerowe). Wychodząc naprzeciw oczekiwaniom rynku TSL, szczeciński terminal kontenerowy wdrożył rozwiązania zapewniające realne skrócenie czasu obsługi kontenerów w porcie. Zastosowanie wspólnego systemu komputerowego CMS Autostore pozwala na szybki obieg informacji o kontenerze, a także skrócenie czasu potrzebnego na dokonanie niezbędnych zgłoszeń. Dzięki idei one stop shop wszystkie kontrole odbywają się w jednym miejscu i czasie, co zmniejsza ilość ruchów kontenerem na terminalu do niezbędnych oraz daje możliwość podjęcia dalszych działań związanych z odprawą celną i wywozem z portu jeszcze tego samego dnia. Kolejnym krokiem jest objęcie zakresem funkcjonowania systemu wszystkich ładunków obsługiwanych w Porcie Szczecin oraz opracowanie i wdrożenie koncepcji wspólnego PCS dla Polski, integrującego działania związane z ładunkami na terenie całego kraju. 


\section{Bibliografia}

Bernacki D., Rozwój portu morskiego w świetle relacji podmiotów zaangażowanych $w$ obstuge morsko-ladowych łańcuchów dostaw [w:] Polskie porty morskie w procesie przemian europejskiego rynku ustug portowych, red. H. Salmonowicz, Wyższa Szkoła Bankowa w Poznaniu, Wydział Ekonomiczny w Szczecinie, 2014.

Dyrektywa Rady 95/64/WE z dnia 8 grudnia 1995 r. w sprawie sprawozdań statystycznych w odniesieniu do przewozu rzeczy i osób drogą morską.

Grzelakowski A., Matczak M., Wspótczesne porty morskie. Funkcjonowanie i rozwój, Wydawnictwo Akademii Morskiej w Gdyni, Gdynia 2012.

Florczyk R., Autostrada celna, „Namiary na morze i handel”, nr 23, Wydawnictwo Promare, Szczecin 2014.

Florczyk R., Wdrożenie pakietu portowego, „Namiary na morze i handel”, nr 5, Wydawnictwo Promare, Szczecin 2015.

Notteboom T. E., Spatial and functional integration of container port systems and hinterland networks in Europe, Land access to sea port, Economic research centre, European Conference of Minister of Transport, Paris 1998.

Ocena realizacji instytucji „Porty 24” w Izbie Celnej w Szczecinie, „Wiadomości celne”, Ministerstwo Finansów, nr 3-4, Warszawa 2015.

Raport z wykonania koordynacji kontroli w ramach Pakietu „Porty 24” za okres od dnia 01.01.2015 r. do 31.03.2015 r., Służba Celna, Ministerstwo Finansów.

Rocznik statystyczny gospodarki morskiej 2014, Główny Urząd Statystyczny.

Ustawa z dnia 20 grudnia $1996 \mathrm{r}$. o portach i przystaniach morskich. 
Dr inż. Bożena Gajdzik

Politechnika Śląska

Wydział Inżynierii Materiałowej i Metalurgii

Katedra Inżynierii Produkcji

ul. Krasińskiego 8, 40-019 Katowice

\section{Zrównoważone praktyki biznesowe w systemie zaopatrzenia przedsiębiorstwa - kryteria środowiskowe i społeczne oceny i segmentacji dostawców}

\section{WPROWADZENIE}

Wraz z rosnącymi wymaganiami rynków odbiorców przedsiębiorstwa produkcyjne zaczęły przywiązywać większą wagę do zakupów zaopatrzeniowych jako funkcji odpowiedzialnej za pozyskiwanie materiałów, komponentów, wyposażenia, części i usług poprzez nabywanie, dzierżawienie lub w inny sposób w celu ich zużycia do produkcji lub odsprzedaży ${ }^{1}$. W wyniku popularyzacji koncepcji zrównoważonego rozwoju wystąpiły tendencje do odpowiedzialnego pozyskiwania zasobów w procesie zaopatrzenia przedsiębiorstwa. Poza ceną i jakością zakupów, odpowiedzialność dotyczy kwestii racjonalnego gospodarowania zasobami, ochrony środowiska w trakcie realizacji dostaw, bezpieczeństwa i higieny pracy, etyczności biznesu dostawców i ich społecznej odpowiedzialności, a także przestrzegania praw człowieka. Poza podstawową kwestią, jaką jest wpływ zakupów zaopatrzeniowych na zyskowność przedsiębiorstwa, pojawiła się kwestia odpowiedzialnego biznesu w trakcie zaopatrzenia. Określenie odpowiedzialny biznes ma szerokie znaczenie, a jego zakres ewoluuje w zależności od uwarunkowań i obostrzeń prowadzenia biznesu. Przedsiębiorstwa produkcyjne coraz częściej kojarzone są z ideą zrównoważonego rozwoju. Dla przedsiębiorstw oznacza to współzależność pomiędzy aspektami środowiskowymi, socjalnymi i ekonomicznymi prowadzonej działalności. Aby działalność producenta w trakcie realizacji funkcji zaopatrzenia była zrównoważona, należy zwrócić większą uwagę na wybór dostawców dóbr zaopatrzeniowych.

Celem niniejszego rozdziału było zestawienie kryteriów środowiskowych i społecznych oceny i segmentacji dostawców. Za studium przypadku posłużyły wymogi stawiane dostawcom w międzynarodowych korporacjach (ArcelorMittal, Siemens). Niniejszy rozdział stanowi wprowadzenie do zagadnień zrównoważonego biznesu w ramach łańcucha dostaw.

${ }^{1}$ K. Lysons, Zakupy zaopatrzeniowe, PWE, Warszawa 2004, s. 13. 


\subsection{IDEA ZRÓWNOWAŻONEGO BIZNESU W FUNKCJI ZAOPATRZENIOWEJ PRZEDSIĘBIORSTWA}

Jednym z głównych warunków sukcesu przemysłu w XXI wieku jest dostosowanie funkcjonowania przedsiębiorstw do przyjętej i realizowanej w Unii Europejskiej - i stopniowo akceptowanej na całym świecie - strategii zrównoważonego rozwoju gospodarki i społeczeństwa, nazywanej w języku angielskim sustainable development. Istota zrównoważonego rozwoju polega na rozwoju społeczno-ekonomicznym, zachowującym cechy trwałości w długim okresie oraz nie działającym destrukcyjnie na środowisko, w którym zachodzi ${ }^{2}$. Biorąc po uwagę dotychczasowe doświadczenia przedsiębiorstw można stwierdzić, że zrównoważony biznes jest orientacją przedsiębiorstw na nowe wartości prowadzące do zrównoważonego rozwoju. Głównym założeniem sustainability jest postrzeganie działalności biznesowej w kontekście jej wpływu na środowisko i społeczeństwo, chociaż nie wyklucza się również szerszego spojrzenia w postaci nowego modelu biznesowego ${ }^{3}$.

W ujęciu logistycznym warunkiem koniecznym zrównoważonego biznesu jest rozpatrywanie biznesu $\mathrm{w}$ ramach łańcucha dostaw. Zakupy zaopatrzeniowe rzutują na zrównoważony rozwój kolejnych elementów tego łańcucha. Procesy i czynności zaopatrzeniowe występują we wszystkich przedsiębiorstwach i oddziaływują na ich działalność produkcyjną. Kryteria podstawowe wyboru dostawców, takie jak: jakość, cena, warunki dostawy ${ }^{4}$, zostały rozszerzone o standardy ochrony środowiska, o wymogi bezpieczeństwa i higieny pracy, o prawa człowieka, a także o etykę i społeczną odpowiedzialność (Corporate Social Responsibility - CSR)5. Rozbudowany zakres kryteriów wynika z konieczności poszukiwania usprawnień w zakresie odpowiedzialnego pozyskiwania zasobów, które jest przejawem troski producentów o zrównoważony biznes.

\subsection{KRYTERIA ODPOWIEDZIALNEGO WYBORU DOSTAWCY}

Odpowiedzialne pozyskiwanie zasobów wymaga rozbudowy stosowanych kryteriów oceny dostawców. Zakres oceny wstępnej obejmuje: sytuację finansową,

\footnotetext{
${ }^{2}$ T. Beatley, The Many Meanings of Sustainability, „Journal of Planning Literature”, Center for Sustainability, Transportation Research Laboratory, Vol. 9, No. 4, May 1995, s. 339-342.

${ }^{3}$ Ch. Byrch, K. Kearins, M. Milne, R. Morgan, Sustainable Development: What does it really mean?, „University of Auckland Business Review”, Vol. 12, Issue 1, Autumn 2010; W.M. Grudzewski, I.K. Hejduk, A. Sankowska, M. Wańtuchowicz, Sustainability w biznesie czyli przedsiębiorstwo przyszłości. Zmiany paradygmatów i koncepcji zarządzania, Poltext, Warszawa 2010, s. 26-27.

${ }^{4}$ K. Lysons, op. cit., s. 13.

${ }^{5}$ E. Jastrzębska, Zarządzanie odpowiedzialnym łańcuchem dostaw jako element wdrażania koncepcji rozwoju zrównoważonego, „Zeszyty Naukowe Kolegium Gospodarki”, t. 32, 2011, s. 217-238; B. Gajdzik, Społeczna odpowiedzialność przedsiębiorstw w proces zakupu dóbr i usług „Problemy Jakości”, nr 9 (45), 2013, s. 16-20.
} 
renomę dostawcy, stosowaną technologię, jakość i cenę wyrobu, miejsce dostawy, terminowość i niezawodność dostaw. W ocenie rozbudowanej uwzględnia się kwestie ochrony środowiska, bezpieczeństwa pracy, etyczności i odpowiedzialności społecznej.

Producenci zobowiązują dostawców do wypełnienia kwestionariuszy oceny. Pytania w kwestionariuszach uporządkowane są warstwowo. Pytania zasadnicze dotyczą: modelu prowadzania biznesu, sytuacji finansowej (EBIT), zapewnienia jakości przez certyfikację Systemu Zarządzania Jakością (ISO9001, ISO/TS 16949 lub inne standardy), kosztów dostaw, posiadanych zezwoleń i licencji na prowadzenie działalności. Pytania dodatkowe obejmują kwestie społeczne i środowiskowe. $\mathrm{Na}$ podstawie studiów przypadków (kwestionariusze oceny dostawców ArcelorMittal i Siemensa) ${ }^{6}$ ustalono kryteria środowiskowe i społeczne oceny dostawców.

Na zakres pytań w kategorii ochrona środowiska składają się: polityka środowiskowa, System Zarządzania Środowiskiem (SZŚ), aspekty środowiskowe, emisje zanieczyszczeń (np. emisje gazów cieplarnianych GHG), zużycie zasobów (np. całkowite zużycie wody, gazu, energii elektrycznej), gospodarka odpadami. Dostawcy zobowiązani są do współpracy z producentem na rzecz zapewnienia polityki odpowiedzialnego pozyskiwania zasobów. Dostawcy muszą wykazać zakres podejmowanych działań w celu spełnienia wymogów producenta. Stosowane dokumenty potwierdzające odpowiedzialność dostawców stanowią załącznik do kwestionariusza.

Pytania o tematyce bezpieczeństwa $i$ higieny pracy dotyczą: polityki bezpieczeństwa pracy, programów bezpieczeństwa procesowego, systemu zarządzania bezpieczeństwem w globalnie akceptowanym standardzie (OHSAS 18001 lub równoważnym), prowadzenia rejestru wypadków (sytuacje potencjalnie niebezpieczne, wypadki, częstotliwość, odsetek wypadków ciężkich), stosowanych procedur bezpieczeństwa. Certyfikaty, rejestry w kwestii bezpieczeństwa pracy (za okres 3 ostatnich lat) uzyskane przez dostawców są dostarczane nabywcom.

Zakres pytań z etyki biznesu wobec dostawców obejmuje zagadnienia: kodeksu postępowania etycznego, przeciwdziałania korupcji oraz oszustwom, procedur zgłaszania niewłaściwych zachowań, prowadzonych postępowań sądowych i wyroków sądowych, dotrzymania warunków umowy, płacenia odszkodowań w związku ze złamaniem postanowień lub naruszeniem kontraktu.

W obszarze CSR pytania dotyczą: prowadzenia i raportowania CSR, stosowanych wskaźników GRI, posiadanych certyfikatów, uzyskanych nagród i wyróżnień.

Pytania w kategorii ochrona praw człowieka obejmują: promocję praw człowieka w ramach łańcucha dostaw (np. poprzez członkostwo w United Nations Global Compact, publiczne zobowiązanie dotyczące przestrzegania standardów

6 Kodeks Odpowiedzialnego Pozyskiwania Zasobów ArcelorMittal, www.arcelormittal.com [19.12.2015]; Kodeks Postępowania dla Dostawców Siemensa, rozdział „Ochrona środowiska”, www.siemens.com [19.12.2015]. 
Międzynarodowej Organizacji Pracy, Ethical Trading Initiative - Inicjatywa na Rzecz Etycznego Handlu) i przestrzeganie wolności stowarzyszeń i negocjacji zbiorowych oraz zakaz pracy przymusowej i pracy dzieci, a także kwestie: zapewnienia godziwej płacy, przestrzegania godzin pracy i wynagradzania nadgodzin, stosowania zabezpieczeń socjalnych. Dostawcy zobowiązani są również do przyjmowania polityki antydyskryminacyjnej, zabraniającej dyskryminacji pracowników i kontrahentów (podwykonawców) ze względu na wiek, płeć, orientację seksualną, rasę, pochodzenie, kolor skóry, narodowość, religię, niepełnosprawność, status HIV, pochodzenie społeczne, wykształcenie, status zatrudnienia, przekonania polityczne lub niezwiązane wyroki kryminalne.

\subsection{KLASYFIKACJA DOSTAWCÓW WEDEUG KRYTERIÓW SUSTAINABILITY}

Stopień zapewnienia dodatkowych wymogów, w związku ze zrównoważonym biznesem, stał się podstawą do poszerzenia klasyfikacji dostawców.

Uwzględniając kategorię oddziaływania na środowisko, dostawcy są klasyfikowani $\mathrm{na}^{7}$ :

- dostawców nie mających wpływu na środowisko lub mających niewielki wpływ na środowisko,

- dostawców mających znaczący wpływ na środowisko.

Dostawcy o nieznacznym oddziaływaniu na środowisko wywiązują się z obowiązków nałożonych przepisami prawa środowiskowego (przestrzeganie obowiązującego prawa jest zasadniczym kryterium realizacji dostaw). Od dostawców znacząco oddziaływujących na środowisko producenci domagają się potwierdzenia systemu zarządzania środowiskowego (system certyfikowany zgodnie z normą ISO 14001). Dostawcy muszą realizować politykę środowiskową poprzez procedury zgodności, programy środowiskowe zgodne z aspektami środowiskowymi. Wymagane jest potwierdzenie realizacji projektów zgodnych z uregulowaniami ochrony środowiska wraz z szczegółowym zakresem odpowiedzialności i kompetencji wykonawców. Dostawcy muszą udostępniać producentom (na ich żądanie) rejestr szkoleń w zakresie ochrony środowiska, a także rejestr audytów i przegląd SZŚ. Ponadto producenci zobowiązują dostawców do szczególnego kontrolowania operacji o dużym znaczeniu dla środowiska (np. dostaw substancji niebezpiecznych) ${ }^{8}$.

Przyjmując kryterium bezpieczeństwa i higieny pracy, podstawą klasyfikacji dostawców jest wdrożony system zarządzania w globalnie akceptowanym standar-

\footnotetext{
${ }^{7}$ N. Ćwik, Wspólna odpowiedzialność. Rola dostaw i zakupów [w:] Wspólna odpowiedzialność. Rola dostaw i zakupów, red. N. Ćwik, FOB 2011, http://odpowiedzialnybiznes.pl/public/files/Wspolna odpowiedzialnosc_FOB_2011.pdf [09.05.2011], s. 9; How To: Manage Your Supply Chains Responsibly, Business In the Community, London 2009, s. 8-13, www.bitc.org.uk/resources/publications/ how_to_manage_your.html [09.05.2011].

${ }^{8}$ E. Jastrzębska, op. cit.
} 
dzie (np.: OHSAS 18001 lub równoważnym) albo alternatywny krajowy system zarządzania. Podstawą oceny jest rejestr wypadków. Dostawców można podzielić na: - dostawców realizujących politykę ograniczania wypadkowości (liczba wypadków według rejestrów spada z roku na rok),

- dostawców nie podejmujących aktywnych (dobrowolnych) działań na rzecz ograniczenia wypadkowości ( $w$ przypadku współpracy ustalany jest termin spełnienia wymogów producenta).

Kolejnym kryterium klasyfikacji dostawców jest odpowiedzialność etyczna i społeczna. Dostawców ocenia się na podstawie kultury organizacyjnej (producenci akceptują lub odrzucają obowiązujące w danej kulturze zwyczaje i okoliczności prowadzenia biznesu, np. kwestie obdarowywania upominkami kontrahentów). Uwzględniając stopień akceptacji wyróżnia się dostawców o:

- akceptowalnych cechach kultury organizacyjnej,

- nieakceptowalnych cechach kultury organizacyjnej.

\subsection{DOKUMENTACJA ZRÓWNOWAŻONEGO SYSTEMU ZAOPATRZENIA}

Odpowiedzialne pozyskiwanie zasobów w celu ich zużycia do produkcji lub wykorzystania zgodnego z przeznaczeniem ${ }^{9}$ stanowi wymóg zrównoważonego rozwoju, opisany w wewnętrznych dokumentach przedsiębiorstw. Dokumenty te mogą przyjmować różną formę, od polityki, wizji i misji odpowiedzialnego pozyskiwania zasobów, poprzez kodeksy i standardy, aż do procedur włącznie. Struktura dokumentacji jest ułożona hierarchicznie według stopnia szczegółowości i kolejności opracowywania. Najbardziej ogólnym dokumentem jest wewnętrzna polityka odpowiedzialnego pozyskiwania zasobów. Jest to deklaracja najwyższego kierownictwa dbałości o zasoby, środowisko i przestrzeganie praw człowieka, w tym: wspieranie wolności zrzeszania, przeciwstawianie się wymuszanej/obowiązkowej pracy, przeciwstawianie się pracy dzieci, eliminacja bezprawnej dyskryminacji, eliminacja molestowania i przemocy, zapewnienie konkurencyjnego wynagrodzenia i utrzymywanie warunków zatrudnienia.

Przeformułowana polityka staje się wizją i misją odpowiedzialnego biznesu. W zrównoważonym zaopatrzeniu producenci będą dążyć do uzyskania optymalnego łańcucha dostaw poprzez wypracowanie rozwiązań równoważących oczekiwania i potrzeby klientów, organów regulacyjnych i społeczeństwa. Misja skierowana jest na budowanie wartości przy jednoczesnym ograniczaniu ryzyka prowadzonej działalności.

Kolejnym dokumentem jest kodeks odpowiedzialnego pozyskiwania dostawców, który reguluje kwestie oczekiwań względem nich w zakresie: bezpieczeństwa pracy, korzystania z środowiska, etyczności i społecznej odpowiedzialności. Zawartość kodeksu stanowią zapisy ogólne.

${ }^{9}$ K. Lysons, op. cit. 
Większy stopień szczegółowości mają standardy i procedury. Zakres dokumentacji szczegółowej obejmuje między innymi odpowiedzialne pozyskiwanie zasobów, bezpieczeństwo procesowe, transport surowców (materiałów, półfabrykatów), magazynowanie i dystrybucję wyrobów.

\subsection{REALIZACJA ZRÓWNOWAŻONEGO ZAOPATRZENIA}

Producent ocenia przestrzeganie przez dostawców wymogów społecznych i środowiskowych w zależności od poziomu ryzyka. Monitoring może przybierać formę kwestionariuszy oceny, wizyt w zakładach dostawców oraz kontroli realizowanych programów. Producenci współpracują z dostawcami w celu usunięcia zidentyfikowanych odchyleń $\mathrm{w}$ trakcie zawierania umów. Producenci zastrzegają sobie prawo do rezygnacji ze współpracy z dostawcami, którzy nie są w stanie przedstawić lub zobowiązać się do ponoszenia odpowiedzialności za środowisko i społeczeństwo. W trakcie zawierania kontraktu dostawca potwierdza, że posiada wszelkie niezbędne pozwolenia lub certyfikaty do realizacji dostawy lub świadczenia usługi. Dokumenty lub ich kopie są sprawdzane pod kątem możliwości ich akceptacji przez komórkę wewnętrzną producenta, najczęściej dział zakupów lub pełnomocnika ds. realizacji polityki zrównoważonego rozwoju (korporacyjne biuro ds. sustainability). Zakres działań w systemie zaopatrzenia obejmuje: współpracę, wsparcie, ustalanie priorytetów, dokumentowanie, usprawnianie, informowanie i szkolenie, a także promowanie odpowiedzialności uczestników łańcucha dostaw (Rysunek 1).

Zakresem współpracy w łańcuchu dostaw objęte są prace na rzecz podnoszenia standardów socjalnych ( $\mathrm{w}$ tym $\mathrm{w}$ zakresie bezpieczeństwa i higieny pracy oraz poszanowania praw człowieka), środowiskowych i etycznych. Współpraca obejmuje m. in. wspólne analizy, np. w ramach wizyt w zakładach, służące ocenie realizacji celów. Relacje uczestników łańcucha oparte są na: uczciwości, obiektywizmie, przejrzystości i profesjonalności. Wsparcie uczestników łańcucha udzielane jest w procesie identyfikacji obszarów niezgodnych $\mathrm{z}$ wymogami odpowiedzialnego zaopatrzenia. Ustalanie priorytetów polega na koncentrowaniu uwagi na tych częściach łańcucha dostaw, w których ryzyko niespełnienia wymagań jest najwyższe i w których można osiągnąć największą poprawę sytuacji w dążeniu do zrównoważonego łańcucha dostaw. Usprawnienia są rezultatem regularnych przeglądów programów podczas audytów dostawców w celu zagwarantowania ich jak największego wkładu w realizację wizji odpowiedzialnych zakupów. Informowanie i szkolenia służą zapewnieniu znajomości zapisów systemów zarządzania iodpowiedniego postępowania. Szkolenia realizowane są przez producentów we współpracy $\mathrm{z}$ dostawcami (popularne są formy e-learningu). Promowanie to wspólne działania producentów i dostawców na rzecz wdrożenia odpowiedzialnych praktyk i zasad postępowania w łańcuchu dostaw w danej branży. 


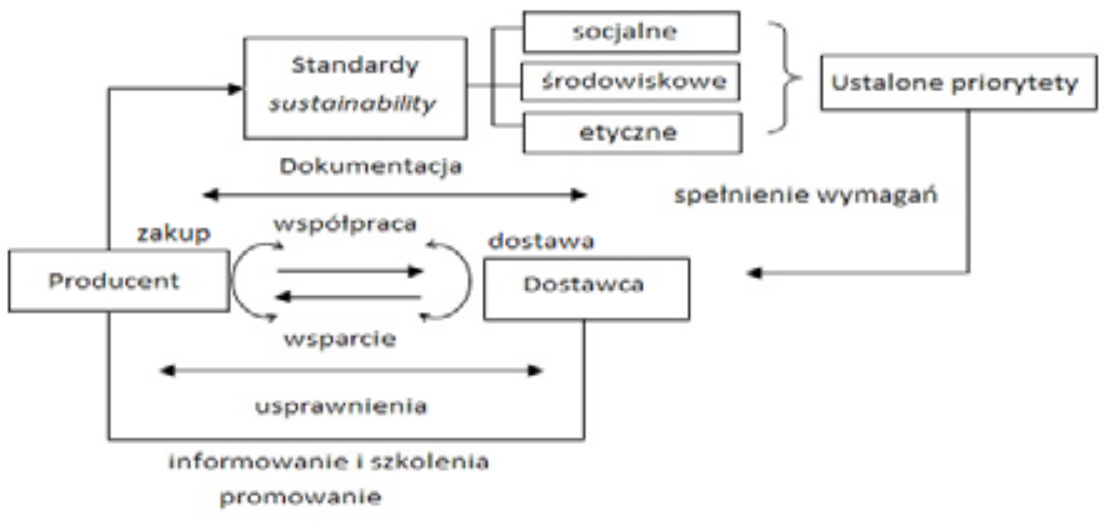

Rysunek 1. Poglądowy model zrównoważonego zaopatrzenia Źródło: opracowanie własne.

Urzeczywistnieniem polityki odpowiedzialnych zakupów są innowacyjne przedsięwzięcia. W dziedzinie ochrony środowiska inwestuje się w czystsze procesy zaopatrzeniowe minimalizujące wpływ na środowisko, zwiększające bezpieczeństwo i odpowiedzialność społeczną. Realizując projekty środowiskowe, dąży się m.in. do zapewnienia efektywności wykorzystania energii i zasobów, zarządzania różnorodnością biologiczną, redukcji odpadów, recyklingu ${ }^{10}$. W obszarze bezpieczeństwa pracy stawia się na bezwypadkowość (zagwarantowanie bezpieczeństwa w trakcie dostaw i świadczenia usług). W obszarze społecznym stawia się na uczciwość biznesową i szacunek do drugiego człowieka ${ }^{11}$.

\section{Podsumowanie}

Zaopatrzenie jest procesem biznesowym podmiotów uczestniczących w zakupie dóbr i usług. Funkcja zaopatrzenia polega $\mathrm{z}$ jednej strony na spełnieniu wymogów względem produktu końcowego, a z drugiej strony na zapewnieniu zrównoważonego rozwoju uczestnków łańcucha dostaw. W ramach zrównoważonego biznesu dostawcy są oceniani przez producentów poprzez kryteria społeczne i środowiskowe. Dostawcy muszą ustalić oddziaływanie na środowisko, ocenić poziom bezpieczeństwa, wykazać się postępowaniem etycznym i odpowiedzialnym społecznie. Producent może udzielić pierwszeństwa dostawcom realizującym wymogi sustainability.

\footnotetext{
${ }^{10}$ N. Edwarczyk, Koncepcja zamkniętej pętli łańcucha dostaw, „Logistyka”, nr 1, 2009.

${ }^{11}$ Ż. Pruska, M. Malak, A. Stachowiak, M. Adamczak, Determinanty wyboru strategii zaopatrzenia w ramach zrównoważonego rozwoju przedsiębiorstw, „Logistyka”, nr 5, 2011; W. Ocieczek, B. Gajdzik, Społeczna odpowiedzialność przedsiębiorstw produkcyjnych, Wydawnictwo Politechniki Śląskiej, Gliwice 2010.
} 


\section{Bibliografia}

Beatley T., The Many Meanings of Sustainability, „Journal of Planning Literature”, Center for Sustainability, Transportation Research Laboratory, Vol. 9, No. 4, May 1995, s. 339-342.

Byrch Ch., Kearins K., Milne M., Morgan R., Sustainable Development: What does it really mean?, „University of Auckland Business Review”, Autumn 2010, Vol. 12, Issue 1.

Ćwik N., Wspólna odpowiedzialność. Rola dostaw i zakupów [w:] Wspólna odpowiedzialność. Rola dostaw i zakupów, (red.) N. Ćwik, FOB 2011.

Edwarczyk N., Koncepcja zamkniętej pętli łańcucha dostaw, „Logistyka”, nr 1, 2009.

Gajdzik B., Społeczna odpowiedzialność przedsiębiorstw w proces zakupu dóbr i usług, „Problemy Jakości", nr 9 (45), 2013, s. 16-20.

Grudzewski W. M., Hejduk I. K., Sankowska A., Wańtuchowicz M., Sustainability w biznesie czyli przedsiębiorstwo przyszłości. Zmiany paradygmatów i koncepcji zarządzania, Poltext, Warszawa 2010.

How To: Manage Your Supply Chains Responsibly, Business In the Community, London 2009.

Jastrzębska E., Zarządzanie odpowiedzialnym łańcuchem dostaw jako element wdrażania koncepcji rozwoju zrównoważonego, „Zeszyty Naukowe Kolegium Gospodarki”, t. 32, 2011, s. 217-238.

Kodeks Odpowiedzialnego Pozyskiwania Zasobów ArcelorMittal.

Kodeks Postępowania dla Dostawców Siemensa, rozdział „Ochrona środowiska”.

Lysons K., Zakupy zaopatrzeniowe, PWE, Warszawa 2004.

Ocieczek W., Gajdzik B., Społeczna odpowiedzialność przedsiębiorstw produkcyjnych, Wydawnictwo Politechniki Śląskiej, Gliwice 2010.

Pruska Ż, Malak M., Stachowiak A., Adamczak M., Determinanty wyboru strategii zaopatrzenia w ramach zrównoważonego rozwoju przedsiębiorstw, „Logistyka”, $\mathrm{nr}$ 5, 2011. 
Aleksandra Janeczek, Zuzanna Nowak

Opiekun: dr inż. Maria Cieśla

Politechnika Śląska

Wydział Transportu

Katedra Logistyki i Transportu Przemysłowego

ul. Krasińskiego 8, 40-019 Katowice

\section{Wprowadzenie do oceny współpracy w łańcuchu dostaw na przykładzie operatora terminala kontenerowego i centrum logistycznego}

\section{WPROWADZENIE}

Z perspektywy odbiorcy proces realizacji zamówienia jest nieskomplikowany, a znaczenie mają wyłącznie skutki pracy wykonawców, którzy są odpowiedzialni za złożony przebieg oparty na współpracy wielu segmentów. Ze strony zlecającego polega on na przekazaniu konkretnego polecenia, które określa zakres powierzanej usługi, rodzaj i właściwości przesyłki, znaki i numery poszczególnych sztuk, ich liczbę, ciężar, wymiary, kubaturę, wszelkie inne dane oraz dokumenty potrzebne do przebiegu procesu logistycznego ${ }^{1}$. Sformułowanie zlecenia poprzedzone jest szeregiem rozmów handlowych oraz negocjacji, które prowadzą do stworzenia satysfakcjonującej dla obu stron oferty zawierającej uszczegółowione warunki współpracy. Zlecenia mogą być przekazywane przez program komputerowy sterujący zasobami magazynowymi oraz zawierający umowy dotyczące wykonania usługi. Opisana procedura nasuwa pytania: czy można ułatwić proces zarządzania w łańcuchu dostaw oraz jaki wpływ może mieć współpraca dwóch przedsiębiorstw? Skłoniło to autorów do przeprowadzenia badań mających na celu analizę rodzaju i charakteru współpracy w ramach partnerstwa w łańcuchu dostaw.

Badania przeprowadzono na studium przypadku operatora transportu intermodalnego, który jest jednocześnie zarządcą terminala kontenerowego znajdującego się $\mathrm{w}$ obszarze centrum logistycznego. Podstawowymi narzędziami badawczymi były: ankieta oraz wywiad. Pomiary przeprowadzono na przełomie listopada i grudnia 2015 roku. Kwestionariusz ankietowy wraz z zestawem pytań z kwestionariusza wywiadu przesłano do Śląskiego Centrum Logistyki S.A. oraz PCC Intermodal Terminal Kontenerowy Gliwice S.A.

1 https://wsiz.rzeszow.pl/pl/Uczelnia/kadra/kferet/Documents/Og\%C3\%B3lna\%20warunki\%20 spedycyjne.pdf [10.12.2015]. 
Celem badań było ustalenie wspólnych komponentów współpracy przedsiębiorstw w łańcuchu logistycznym. Obszary tematyczne zawarte w kwestionariuszu dotyczyły struktury organizacyjnej, sposobu zarządzania, celów strategicznych, form współpracy, zakresu prowadzonych działań i infrastruktury technicznej.

\subsection{WSPÓŁPRACA POMIĘDZY CENTRUM LOGISTYCZNYM A TERMINALEM KONTENEROWYM}

\subsubsection{STANDARDOWY PRZEBIEg WSPÓŁPRACY}

Obecnie najpopularniejszym rozwiązaniem łączącym zakres usług centrum logistycznego oraz terminala kontenerowego jest zlokalizowanie obu firm na terenie jednego obiektu. Terminal wykorzystywany jest wyłącznie do realizacji zleceń i umów, które zawierane są przez centrum logistyczne ${ }^{2}$. Takie działanie umożliwia outsourcing, czyli korzystanie z kompleksowych usług będących kombinacją różnorodnych usług cząstkowych sprzedawanych i rozliczanych jako jednostka, jakie oferują zewnętrzni wykonawcy ${ }^{3}$. Oznacza to przekazanie funkcji wykonywanej dotychczas przez pracowników danego przedsiębiorstwa firmie zewnętrznej, czyli usługodawcy (outsourcerowi), nieposiadającemu dotychczas żadnych bezpośrednich relacji z firmą, a specjalizującemu się w określonej dziedzinie ${ }^{4}$. Polskimi odpowiednikami wyrazu „outsourcing” są terminy „wydzielenie, wyodrębnienie” oznaczające wykorzystanie zasobów zewnętrznych ${ }^{5}$, które może być źródłem dodatkowych przychodów oraz ujednoliceniem zakresu obowiązków danego obiektu bez wpływu na zakres oferowanych usług.

Typowym elementem współpracy podmiotów gospodarczych w zakresie działań logistycznych i transportowych jest podejmowanie decyzji przez centrum logistyczne, które zajmuje się sprawami administracyjno-biurowymi. Terminal przeładunkowy ma wyłącznie wykonawczy charakter działalności.

Działania z zakresu promocji i marketingu przedsiębiorstw kierują klienta na działalność centrum logistycznego i traktują funkcjonowanie terminala przeładunkowego jako działalność usługową.

\footnotetext{
${ }^{2}$ Centrum logistyczne - jednostka gospodarcza, przedsiębiorstwo, którego zadaniem jest koordynowanie obsługi logistycznej, tzn. magazynowo - transportowej w jednym miejscu i przy udziale technologii informatycznych. Za: E. Gołembska, Logistyka C. H. Beck, Warszawa 2012.

Logistyka - proces planowania, realizacji i kontrolowania sprawności i ekonomicznej efektywności przepływu surowców, produkcji niezakończonej i wyrobów gotowych oraz związanych z tym informacji od miejsca pochodzenia do miejsca konsumpcji w celu zaspokojenia wymagań klientów. Za: S. Krawczyk, Logistyka. Teoria i praktyka 1, Difin, Warszawa 2011.

${ }^{3}$ J. Penc, Leksykon biznesu, Placet, Warszawa 1997.

${ }^{4}$ M. Kłos, Outsourcing w polskich przedsiębiorstwach, CeDeWu.pl Wydawnictwa Fachowe, Warszawa 2010.

${ }^{5}$ K. Markowska, A. Merkisz-Guranowska, Outsourcing usług transportu kolejowego, Politechnika Poznańska, Poznań 2015.
} 
6. WPROWADZENIE DO OCENY WSPÓŁPRACY W ŁAŃCUCHU DOSTAW NA PRZYKŁADZIE...

\subsubsection{WSPólpraca Śląskiego Centrum Logistycznego Z TERMinAlem Kontenerowym}

Analizując współpracę pomiędzy wymienionymi firmami dostrzeżono różnice $\mathrm{w}$ odniesieniu do typowej działalności firm zajmujących się branżą Transport-Spedycja-Logistyka - TSL. Najważniejszą z rozbieżności jest forma współpracy przedsiębiorstw, która mieści się w zakresie partnerstwa. W dobie wzrastającej niepewności i dynamicznych zmian nabiera ono szczególnego znaczenia.

Relacje partnerskie opierają się na czynnikach, do których należą przede wszystkim: otwartość, zaufanie, komunikacja oraz wymiana wiedzy. Te cechy można odnaleźć we współpracy analizowanych jednostek, które w ramach współdziałania w łańcuchu dostaw korzystają z wymiany doświadczeń pracowników, spotkań na poziomie top-managementu oraz opracowywania wspólnych ofert dla klientów. Elementy mają charakter ciągły i pogłębiający się. Gwarantują długoterminowe rezultaty. Na polskim rynku trudno jest znaleźć skuteczne wdrożenie podobnych rozwiązań, wśród przedsiębiorstw współpracujących w łańcuchu dostaw. Kooperacja równoległa spółek oznacza, że producent wyrobu bądź usługi finalnej współpracuje z kooperantami dostarczającymi określone elementy wyrobu lub świadczącymi usługi w poszczególnych fazach procesu technologicznego ${ }^{6}$. W analizowanym przypadku spółki mają jednakowy wpływ w sprawach decyzyjnych, ponieważ współpracują transakcyjnie, procesowo i strategicznie.

Spółki posiadają duże doświadczenie funkcjonowania na rynku, co daje przewagę wśród konkurencji. Dłuższy staż działania ma Śląskie Centrum Logistyczne, które zarejestrowało działalność w 1989 roku, jako Śląski Wolny Obszar Celny. Firma zarządzała i administrowała portami w Gliwicach oraz Kędzierzynie-Koźlu. Nazwa spółki została zmieniona na obecną w 2002 roku. Trzy lata później działalność rozpoczęła spółka PCC Intermodal, pojawiając się na rynku w 2005 roku pod pierwszą nazwą PCC Rail Containers Sp. z o.o. w Sławkowie. W celu uruchomienia dodatkowych połączeń w 2011 roku przeniesiono działalność operacyjną do Gliwic. Firmy te mają przyjęte strategie działania do 2020 roku.

Współpracujące spółki mają ściśle określone cele strategiczne, zależne od charakteru działalności. Priorytetem dla operatora transportu intermodalnego jest dostarczanie nowatorskich rozwiązań logistycznych przy maksymalnym ukierunkowaniu działań na satysfakcję partnerów. Terminal kontenerowy dąży do bycia wiodącym operatorem intermodalnym działającym w oparciu o sieć nowoczesnych terminali. Za podstawę służącą realizacji misji i celów, Śląskie Centrum Logistyki przejęło system zarządzania jakością zgodny z normą PN-EN ISO 9001, poprzez który dąży do ciągłego podnoszenia wymiaru usług logistycznych. Certyfikacja wspomnianego systemu nakłada obowiązek ciągłej dbałości o jakość

${ }^{6}$ A. Adamik, Współpraca małych i średnich przedsiębiorstw w regionie, Difin, Warszawa 2012. 
wyrobów i usług towarzyszących ${ }^{7}$. PCC Intermodal nie posiada certyfikowanego systemu zarządzania. Obie spółki działają elastycznie i są otwarte na potrzeby rynku. Dążą do wdrożenia i wykorzystywania nowoczesnych technologii, co prowadzi do opracowania kompleksowych rozwiązań logistycznych.

Śląskie Centrum Logistyczne oferuje usługi magazynowe oraz przeładunkowe, specjalizuje się w pełnej obsłudze klientów, poczynając od wszechstronnej analizy potrzeb, doradztwa, realizacji projektu aż po dostawę. Dysponuje przy tym własną agencją celną, flotą samochodową oraz terminalem celnym i kontenerowym. Spółka PCC Intermodal nie posiada własnej floty. Wykorzystuje podwykonawstwo w zakresie zakupu usług transportowych. Należy przy tym wyraźnie odróżnić outsourcing od podwykonawstwa. Podwykonawstwo występuje, gdy zleca się wykonanie działania innym firmom z powodu braku zdolności produkcyjnych do samodzielnego wykonania. Jest to zakup określonych produktów wykonywanych na zamówienie, zawierających wskazania i szczegóły techniczne. Podwykonawstwo nie pociąga zmian strukturalnych w firmie. Outsourcing oznacza wydzielenie ze struktury organizacyjnej przedsiębiorstwa macierzystego realizowanych przez nie funkcji i przekazanie ich do realizacji innym podmiotom gospodarczym. Outsourcing powoduje zmiany w strukturach organizacyjnych i jest formą restrukturyzacji firmy ${ }^{8}$.

Oprócz usług logistycznych, firmy oferują działania w procesach pomocniczych i dodatkowych oraz następujące usługi specjalistyczne:

- krótkoterminowe składowanie opakowań,

- etykietowanie i znakowanie produktów,

- konfekcjonowanie i paletyzowanie towarów,

- konsolidacja przesyłek,

- pakowanie i koncentracja wysyłek,

- kontrola cech i parametrów produktów,

- przeładunki bezpośrednie,

- cross-docking,

- obsługa dokumentacyjna,

- doradztwo.

\subsection{ANALIZA WSPÓEPRACY OPERATORA TRANSPORTU INTERMODALNEGO I CENTRUM LOGISTYCZNEGO}

Badania ankietowe umożliwiły analizę współpracy podmiotów. Pierwsza $\mathrm{z}$ ankiet zawierała pytania na temat organizacji, w tym część pytań otwartych, które pozwoliły na zapoznanie się $\mathrm{z}$ ogólnym charakterem działalności firmy. Druga systematyzowała wiedzę dotyczącą zakresu współpracy spółek.

${ }^{7}$ B. Gajdzik, J. Szymszal, J. Piątkowski, Logistyka w przedsiębiorstwie. Wybrane metody jakościowe i ilościowe w sektorze hutniczym, Wydawnictwo Politechniki Śląskiej, Gliwice 2011.

${ }^{8}$ S. Krawczyk, op. cit. 
$\mathrm{Na}$ podstawie badań stworzono wykres przedstawiający aktualną ocenę wag elementów współpracy $\mathrm{w}$ łańcuchu dostaw pomiędzy analizowanymi firmami (Wykres 1). Przygotowane narzędzie badawcze „aktualna ocena wag elementów współpracy w łańcuchu dostaw" może stanowić uniwersalną formę do ogólnego rozpoznania komponentów współpracy w łańcuchu dostaw i ich oceny.

Na podstawie wykonanych badań, w których firmy oceniły znaczenie elementów współpracy, określono kluczowe obszary działań w łańcuchu dostaw. Zaobserwowano największe znaczenie partnerstwa biznesowego opartego na wymianie doświadczeń. Jest to punkt wyjściowy w strategii rozwoju firm.

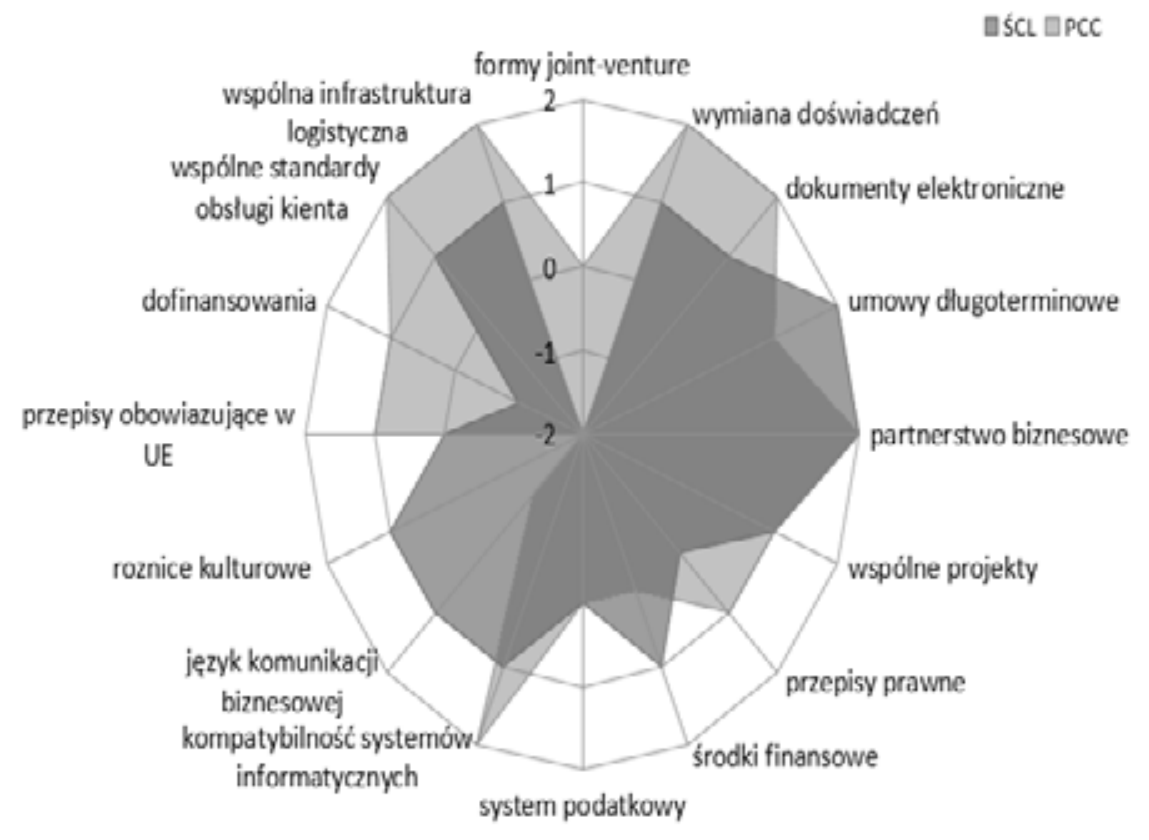

Wykres 1. Aktualna ocena wag elementów współpracy w łańcuchu dostaw

Źródło: opracowanie własne na podstawie badań bezpośrednich (opisanych we wprowadzeniu do artykułu).

Zidentyfikowano powiązania w zakresie:

- wymiany doświadczeń pracowników - firmy wskazały fundamentalne znaczenie tego czynnika,

- jednolitych standardów obsługi klienta - po wieloletnim udoskonalaniu mają istotny wpływ na pozyskiwanie nowych zleceń,

- wspólnej infrastruktury logistycznej - zmniejsza wydatki na niezbędne inwestycje, ponieważ część renowacji leży po stronie centrum logistycznego, a część po stronie terminala kontenerowego, 
- wspólnych projektów - wymiana doświadczeń wpływa na doskonalenie działań, zawęża współpracę i nakierowuje na możliwość osiągania wspólnych celów,

- kompatybilności systemów informatycznych - jest równorzędna z rozwojem dokumentacji elektronicznej,

- przepisów prawnych - obejmują system podatkowy,

- umów długoterminowych - oddziałują na poziom środków finansowych firm, pociągają za sobą przejrzystą organizację pracy.

W ramach współdziałania w łańcuchu dostaw firmy korzystają z popularnych i skutecznych form współpracy, jakimi są spotkania na poziomie top-managemen$t u$. Dodatkowo ŚCL uwzględnia różnice kulturowe i język komunikacji biznesowej. Ma to swoje uzasadnienie w rzeczywistości, ponieważ ŚCL jest odpowiedzialne za zawieranie międzynarodowych umów i zwalnia terminal z tego obowiązku. $\mathrm{Na}$ terenie PCC odbywa się głównie manewrowanie towarami oraz realizacja zleceń nadesłanych $\mathrm{z}$ centrum logistycznego. $\mathrm{Z}$ racji tego język komunikacji biznesowej nie stanowi bariery. W ten sposób można również odnieść się do różnic kulturowych, które nie są zauważane przez PCC ze względu na zasięg prowadzonych działań. PCC wskazuje na formy joint-venture oraz podkreśla znaczenie dofinansowań i przepisów obowiązujących w Unii Europejskiej. Wynika to z aktualnej polityki wewnętrznej kraju oraz z opracowanych ścieżek rozwoju przyjętych przez rząd.

Dalszym etapem rozwoju powinna być próba ujednolicenia elementów współpracy, gdzie zaobserwowano znaczne różnice w ocenie ważności. Może to wpłynąć na utożsamianie się z tymi samymi zamierzeniami, a znormalizowanie celów spowoduje poszerzenie zakresu działań. Skutkiem będzie wzrost znaczenia firm na rynku.

Wdrożonym sposobem dbania o klienta jest baza Customer Relationship Management (CRM), która przyjęta jako strategia biznesowa ma na celu zwiększenie długoterminowej współpracy z konsumentami. CRM stanowi odpowiedź na:

- coraz mniejszą lojalność klientów,

- wzrost konkurencji,

- coraz większe koszty pozyskania nowych klientów,

- większą elastyczność produkcji,

- wzrost liczby kanałów dystrybucji9.

Firmy sugerujące się filozofią CRM dążą do dopasowania się do indywidualnych potrzeb odbiorców, regularnie oceniając poziom współpracy z klientem. Najbardziej efektywnym, wykorzystywanym w tym celu narzędziem jest przeprowadzenie wywiadu bądź ankiety. Na podstawie feedbacku ${ }^{10}$ od kluczowych klientów tworzone są propozycje zmian mających wpływ na jakość usług.

\footnotetext{
${ }^{9}$ A. Sołtysik - Piorunkiewcz, Zarzadzanie relacjami z klientem $z$ wykorzystaniem techniki Customer Care - charakterystyka systemów CMR, www.sbc.org.pl/Content/19341/piorunkiewicz.pdf [13.12.2015].

${ }^{10}$ Feedback - z ang. opinie, wyniki, reakcje, odczucia, informacje zwrotne.
} 
Dzięki badaniom poziomu zadowolenia można wyciągnąć wnioski potrzebne do stworzenia spersonalizowanych form promocji wobec stałych klientów. Spółki stosują upusty i rabaty dla klientów, a Śląskie Centrum Logistyczne oferuje także dłuższy okres rozliczeniowy należności.

Współpracujące firmy posiadają systemy informatyczne, które są kompatybilne z systemem kontrahenta $\mathrm{w}$ oparciu o Internet i zamówienia elektroniczne. Śląskie Centrum Logistyczne wskazuje na ważną rolę, jaką odgrywa system EDI. Jest to wymiana dokumentów i innych danych w formatach opisanych międzynarodowymi standardami, między systemami informatycznymi partnerów handlowych, przy minimalnej interwencji człowieka ${ }^{11}$. System EDI jest innowacyjnym rozwiązaniem z pogranicza informatyki i telekomunikacji, które umożliwia eliminację dokumentów papierowych, zwiększając w ten sposób efektywność działań. Jest to najprostszy sposób na realizację transakcji handlowych, który łączy bezpośrednio systemy informatyczne współpracujących ze sobą firm. Umożliwia natychmiastowe przekazywanie informacji przy użyciu standardowych i akceptowalnych na całym świecie formatów danych. Elektroniczny obieg dokumentów, który towarzyszy procesom dystrybucji, pozwala na zmniejszenie ryzyka pomyłek i przyspiesza realizację zamówienia.

\subsection{ANALIZA OBSZARU DZIAEAŃ JEDNOSTEK WE WSPÓŁPRACY ŚCL S.A. I PCC InTERModal S.A. Terminal Kontenerowy Gliwice}

Obszar działań spółek podzielono na następujące procesy: logistyczne, pomocnicze oraz dodatkowe. W ramach podziału wyodrębnia się poszczególne działania, które firmy mogą wykonywać w ramach współpracy bądź prowadzić je samodzielnie. Elementy te przedstawione zostały na Rysunku 1.

W sferze procesów logistycznych transport wewnętrzny na terenie zakładu jest całkowicie realizowany w ramach współpracy. Kolejne działania: sterowanie ładunkami bądź przeładunek na terminalu kontenerowym obsługiwane są przez ŚCL przy porozumieniu z PCC Intermodal. W czynnościach, takich jak: zarządzanie zapasami, zamówieniami oraz taborem a także dostępną powierzchnią magazynową działania prowadzi PCC Intermodal, pozostając w łączności ze ŚCL.

W tym obszarze zlokalizowano działania prowadzone przez każdą z firm samodzielnie. Są nimi: transport zewnętrzny, magazynowanie, pakowanie, komplementacja oraz dekomplementacja, a także zapewnienie zasady "first in first out" w przepływie ładunków.

Następną płaszczyzną poddaną analizie są procesy pomocnicze, gdzie w ramach współpracy odbywa się obsługa celna oraz cały zakres działań prowadzonych $w$ ramach promocji i marketingu. PCC Intermodal podejmuje działania z zakresu usług informacyjnych i informatycznych, gromadzenia danych dotyczą-

${ }^{11}$ www.edi.pl [12.12.2015]. 


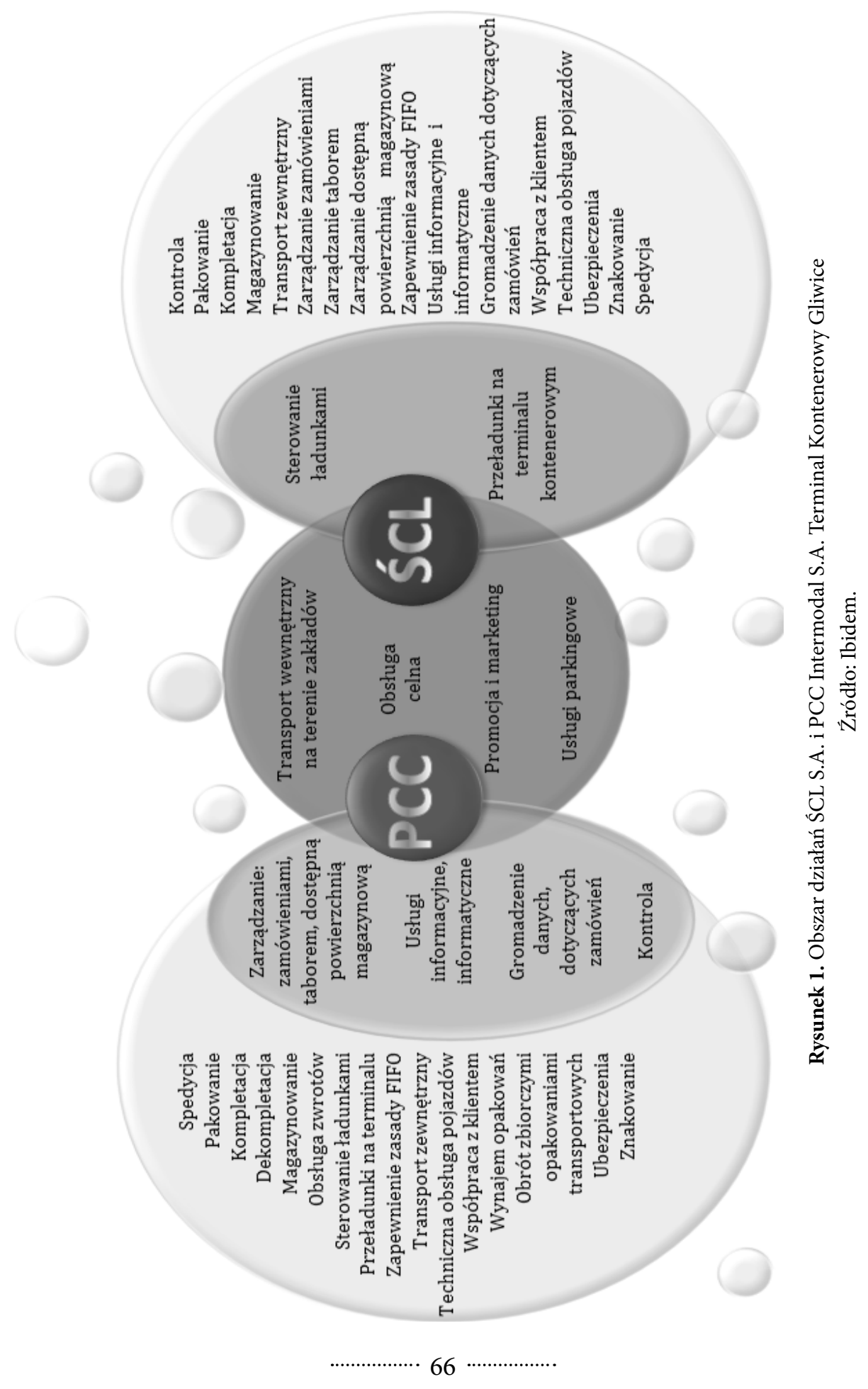


cych wielkości i struktury zamówień oraz kontroli. W ramach tego obszaru skoncentrowana jest niewielka część działań prowadzonych samodzielnie przez spółki, takich jak: spedycja, znakowanie, ubezpieczenia oraz współpraca z klientem.

W ostatnim $\mathrm{z}$ wyróżnionych procesów odnotowano współpracę $\mathrm{w}$ dziedzinie usług parkingowych. Pozostałe działania, jakimi są: techniczna obsługa pojazdów, sprzedaż paliw, olejów i akcesoriów, a także usługi księgowo-rachunkowe, telekomunikacyjne oraz doradcze, prowadzone są niezależnie przez każdą ze spółek.

W ujęciu globalnym działania podejmowane w ramach współpracy są nieznaczne. Przeważają czynności wykonywane samodzielnie przez każdą ze spółek. Mimo to, dotychczasowa aktywność pozwoliła na wypracowanie elementów współpracy na wystarczającym poziomie, by przynosić stałe korzyści i nieustannie się rozwijać.

\section{Podsumowanie}

Przyjmując orientację na klientów, na wejściu do łańcucha wartości znajdują się oczekiwania i potrzeby klientów, a na wyjściu poziom ich zadowolenia. Jest to tzw. cykl od potrzeb do ich zaspokojenia. Udzielenie odpowiedzi na pytanie: jakie są potrzeby klientów, stanowi podstawę do budowania łańcucha wartości produktów przez poszczególne ogniwa ${ }^{12}$. W analizowanych przypadkach wykorzystane zostały wszystkie korzyści i możliwości płynące ze współpracy wzajemnie uzupełniających się podmiotów gospodarczych: Śląskiego Centrum Logistyki S.A. i PCC Intermodal Terminal Kontenerowy Gliwice S.A. Szczegółowo opracowane plany strategiczne przedsiębiorstw zawierają długoletni porządek współpracy, który wspomaga osiąganie głównych celów oraz realizowanie sformułowanej wizji. Plany prowadzą do stałej współpracy na gruncie transakcyjnym, procesowym i strategicznym. Istotna jest percepcja kontrahentów o współtworzonym partnerstwie i pomiar możliwych występujących luk. Właściwy wybór metod pomiaru współpracy w obrębie łańcucha dostaw pozwala na osiągnięcie elastyczności będącej odpowiedzią na działania konkurencji i oczekiwania odbiorców.

Przeprowadzone badania wykazały, że analizowane podmioty rozszerzają zakres współpracy. Dotychczas ulepszone zostały systemy informatyczne. Miało to korzystny wpływ na pracę działów: finansowego, kontroli jakości, sprzedaży. Poszczególne działy wypracowały jednakowy, wysoki poziom obsługi klienta. Rozwinięta współpraca przedsiębiorstw prowadzi do dynamicznych zmian i rozwoju spółek.

${ }^{12}$ B. Gajdzik, Struktura łańcucha wartości wyrobów $w$ sektorze przedsiębiorstw hutniczych, „Hutnik - Wiadomości Hutnicze” 78(2), 2011. 
Przeprowadzone przez autorów badania miały charakter pilotażowy i będą stanowiły przedmiot dalszych rozważań z uwzględnieniem następujących zakresów badawczych: badanie wizerunku przedsiębiorstwa, badanie skuteczności zarządzania i efektywności pracowników, badanie koordynacji procesów logistycznych, badanie procesów subsydialnych.

\section{BibLIOgRAFiA}

Adamik A., Współpraca małych i średnich przedsiębiorstw w regionie, Difin, Warszawa 2012.

Coyle J. J., Bardi E. J., Langley Jr. C. J., Zarzadzanie logistyczne, PWE, Warszawa 2002.

Gajdzik B., Struktura łańcucha wartości wyrobów $w$ sektorze przedsiębiorstw hutniczych, „Hutnik - Wiadomości Hutnicze” 78(2), 2011.

Gajdzik B., Szymszal J., Piątkowski J., Logistyka w przedsiębiorstwie. Wybrane metody jakościowe i ilościowe w sektorze hutniczym, Wyd. Politechniki Śląskiej, Gliwice 2011.

Gołembska E., Logistyka, C. H. Beck, Warszawa 2012.

Kłos M., Outsourcing $w$ polskich przedsiębiorstwach, CeDeWu.pl Wydawnictwa Fachowe, Warszawa 2010.

Krawczyk S., Logistyka. Teoria i praktyka 1, Difin, Warszawa 2011.

Markowska K., Merkisz-Guranowska A., Outsourcing usług transportu kolejowego, Politechnika Poznańska, Poznań 2015.

Penc J., Leksykon biznesu, Placet, Warszawa 1997.

www.edi.pl [12.12.2015].

www.sbc.org.pl/Content/19341/piorunkiewicz.pdf [13.12.2015].

www.wsiz.rzeszow.pl/pl/Uczelnia/kadra/kferet/Documents/Og\%C3\%B3lna\%20warunki\%20spedycyjne.pdf [10.12.2015]. 
Katarzyna Kowalska, Lucyna Sikora

Politechnika Poznańska

Wydział Inżynierii Zarządzania

Katedra Zarządzania Produkcją i Logistyki

ul. Strzelecka 11, 60-965 Poznań

\section{Lańcuch dostaw lean czy agile - jak efektywnie i innowacyjnie zarządzać łańcuchem dostaw?}

\section{WPROWADZENIE}

Popularność łańcuchów dostaw i problem zarządzania nimi zapoczątkowały ideę stworzenia tej pracy. Rozdział przedstawia problem, z jakim borykają się przedsiębiorstwa przy wyborze odpowiedniej strategii zarządzania łańcuchem dostaw. Autorki przedstawiają popularne strategie zarządzania łańcuchem dostaw - strategię Lean i strategię Agile. Podstawowym celem rozdziału jest zestawienie obu strategii, porównanie ich i stworzenie kryteriów doboru koncepcji do łańcucha dostaw. W tym celu dokonano krytycznego przeglądu literatury w obszarze strategii Lean i Agile, które zostały poddane analizie. Rozdział zawiera kolejno części dotyczące definicji łańcucha dostaw, porównywanych strategii oraz kryteriów wyboru adekwatnej strategii.

\subsection{Pojęcie lańcucha dostaw}

Termin „łańcuch dostaw” nie ma jednoznacznej definicji. Co więcej, pojęcie to miało różne znaczenie, co wiązało się z rozszerzaniem obszarów logistyki. Wielu ekspertów tworzyło własne spojrzenie na to zagadnienie, co przedstawia Tabela 1. W zestawionych definicjach zwrócono uwagę na takie aspekty jak: poprawny przepływ dóbr oraz informacji, otrzymanie wartości dodanej dla klienta i uczestników łańcucha. Co ważniejsze, zaznaczono, że łańcuch dostaw to współpraca grupy przedsiębiorstw, ale $\mathrm{z}$ różnych obszarów i dziedzin. Wskazane wyżej definicje pokazują, że bardzo trudno jest wyobrazić sobie wytwarzanie dóbr i ich dystrybucję bez połączenia tych procesów $\mathrm{w}$ dobrze prosperujący łańcuch dostaw. Aktualnie zintegrowanie wszystkich ogniw i dopasowanie łańcucha do specyfiki towarów i wymagań klientów dopiero daje podstawę i możliwość do osiągnięcia sukcesu. Przykładową strukturę łańcucha dostaw przedstawia Rysunek 1. 
Tabela 1. Wybrane definicje łańcucha dostaw

\begin{tabular}{|c|c|c|c|}
\hline Definicja & Rok & Autor & Źródło \\
\hline $\begin{array}{l}\text { „Integracja kluczowych procesów biz- } \\
\text { nesowych od początkowych dostaw- } \\
\text { ców do końcowych użytkowników, } \\
\text { którzy dostarczają produkty, usługi } \\
\text { i informacje oraz dodają wartość dla } \\
\text { klientów i innych interesariuszy łańcu- } \\
\text { cha dostaw”. }\end{array}$ & 1998 & $\begin{array}{l}\text { D. Lambert, } \\
\text { M. Cooper, } \\
\text { J. Pagh }\end{array}$ & $\begin{array}{l}\text { Supply Chain Management: } \\
\text { Implementation Issues and Re- } \\
\text { search Opportunities, „Inter- } \\
\text { national Journal of Logistics } \\
\text { Management", Vol. 9, No. 2, } \\
\text { 1998, s. 1. }\end{array}$ \\
\hline $\begin{array}{l}\text { „Lańcuch dostaw to struktura organi- } \\
\text { zacyjna grupy przedsiębiorstw reali- } \\
\text { zujących wspólne działania niezbędne } \\
\text { do zaspokojenia popytu na określone } \\
\text { produkty”. }\end{array}$ & 2006 & M. Fertsch & $\begin{array}{l}\text { Słownik terminologii logistycznej, } \\
\text { ILiM, Poznań 2006, s. } 95 .\end{array}$ \\
\hline $\begin{array}{l}\text { „Lańcuch dostaw to współdziałające } \\
\text { w różnych obszarach funkcjonalnych } \\
\text { firmy, jak wydobywcze, produkcyjne, } \\
\text { handlowe, usługowe”. }\end{array}$ & 2010 & $\begin{array}{l}\text { J. Witkow- } \\
\text { ski }\end{array}$ & $\begin{array}{l}\text { Zarządzanie łańcuchem dostaw, } \\
\text { PWE, Warszawa } 2010 .\end{array}$ \\
\hline $\begin{array}{l}\text { Łańcuch dostaw „musi stanowić } \\
\text { sprawny oraz skuteczny system, który } \\
\text { działa w praktyce i tworzy wartość do- } \\
\text { daną dla wszystkich jego uczestników. } \\
\text { Jest on odpowiedzialny za koordynację } \\
\text { przepływu dóbr materialnych, usług } \\
\text { i informacji". }\end{array}$ & 2014 & $\begin{array}{l}\text { P. Tomski, } \\
\text { R. Królik }\end{array}$ & $\begin{array}{l}\text { Informatyzacja wybranych pro- } \\
\text { cesów logistycznych na przykła- } \\
\text { dzie przedsiębiorstwa hutniczego, } \\
\text { „Logistyka”, nr 6, 2014, s. } 12270 \text {. }\end{array}$ \\
\hline
\end{tabular}

Źródło: opracowanie własne.

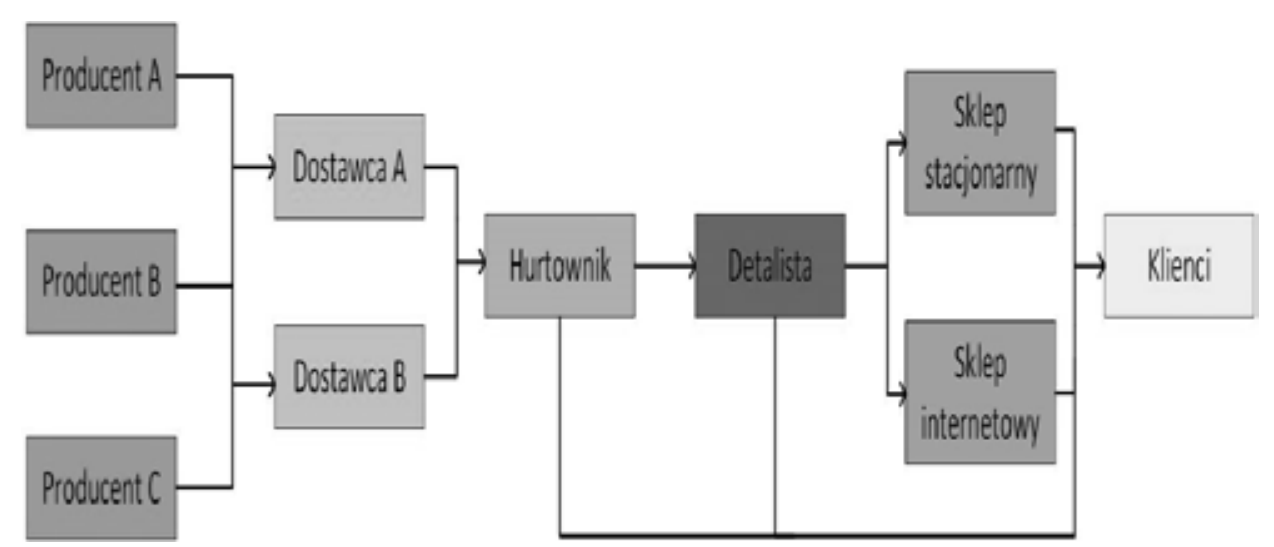

Rysunek 1. Przykładowa struktura łańcucha dostaw Źródło: opracowanie własne. 


\subsection{STRATEgIA LEAN - SZCZUPEY LAŃCUCH DOSTAW}

Rodowodu koncepcji Lean upatrywać można w Systemie Produkcyjnym Toyoty ${ }^{1}$. Podstawą do wyjaśnienia założeń koncepcji jest wyjaśnienie źródłowego pojęcia: „lean”, które w najprostszym tłumaczeniu z języka angielskiego oznacza „szczupły”. Określenie to stanowi ideę metody zarządzania - Lean Management, która ma na celu eliminację wszelkiego marnotrawstwa oraz nie stanowi wartości dodanej z punktu widzenia klienta w każdym aspekcie funkcjonowania przedsiębiorstwa ${ }^{2}$. Zgodnie z zasadami tej koncepcji opracowano metodę zarządzania produkcją (Lean Production) ${ }^{3}$, w której rozsądnie wykorzystuje się zasoby. Strategia ta może być zastosowana również w innych obszarach, jak na przykład w łańcuchu dostaw ${ }^{4}$. Podstawą strategii jest traktowanie strat i zysków danego ogniwa jako strat i zysków całego łańcucha. Najważniejsze jest to, by każdy z uczestników uznawał za nadrzędne dostarczanie klientowi wartości. Należy pamiętać przy tym, iż wprowadzanie odrębnych zmian w ogniwach nie przyniesie efektu dla całego łańcucha, zatem niezbędna jest kompleksowość. Okazuje się, że nie należy to do najprostszych czynności, tym bardziej, iż ograniczone jest zastosowanie takich metod, jak Kanban, teorii ograniczeń czy też Just in Time. Wdrożenie koncepcji powinno odbywać się etapami (Rysunek 2).

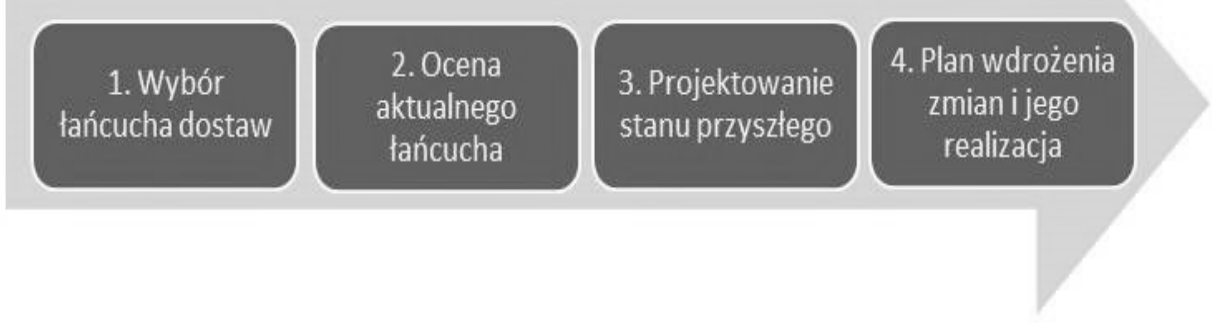

Rysunek 2. Etapy wdrożenia strategii Lean w łańcuchu dostaw

Źródło: opracowanie własne na podstawie: M. Kruczek, Z. Żebrucki, Doskonalenie struktury łańcucha dostaw $z$ wykorzystaniem koncepcji Lean, „Logistyka”, nr 2, 2011.

\footnotetext{
${ }^{1}$ A. Parkes, Lean Management Genesis, „Management”, Vol. 19, No. 2, 2015, s. 107.

${ }^{2}$ A. Piasecka-Głuszak, Lean Management w polskich przedsiębiorstwach przy wykorzystaniu wybranych narzędzi rozwiazywania problemów - wyniki badań, Praca Naukowa Uniwersytetu Ekonomicznego, Wrocław 2014, s. 89.

${ }^{3}$ R. Wolniak, Metody i narzędzia Lean Production i ich rola $w$ ksztattowaniu innowacji $w$ przemyśle [w:] Innowacje w zarządzaniu i inżynierii produkcji, Oficyna Wydawnicza Polskiego Towarzystwa Zarządzania Produkcją, Opole 2013, s. 524-534.

${ }^{4}$ M. Kruczek, Z. Żebrucki, Doskonalenie struktury łańcucha dostaw z wykorzystaniem koncepcji Lean, „Logistyka”, nr 2, 2011, s. 355.
} 
Pierwszym zadaniem jest wybranie łańcucha dostaw. Najpierw należy ustalić jego główne cele, dobrać dostawców, określić planowane, niezbędne warunki współpracy i opracować strumień wartości. Następnym krokiem jest ocena aktualnego łańcucha, która polega przede wszystkim na ocenie dostawców i odbiorców. Dalej wyznacza się działania - jest to projektowanie stanu przyszłego. Określa się, jakie zmiany należy wprowadzić dla podniesienia efektywności działań. Przykładem tego może być wyeliminowanie mudy, która w łańcuchu dostaw prezentuje się nieco inaczej w porównaniu z produkcją (Tabela 2).

Tabela 2. Rodzaje mudy w łańcuchu dostaw i ich charakterystyka

\begin{tabular}{|c|c|c|}
\hline Muda & Charakterystyka & Przykład \\
\hline Nadprodukcja & Podaż przewyższająca popyt & $\begin{array}{l}\text { Dostawy wyprzedzają zapotrzebowanie na wy- } \\
\text { roby, półprodukty, surowce }\end{array}$ \\
\hline Oczekiwanie & $\begin{array}{l}\text { Wszelka niesynchronizacja } \\
\text { czasowa procesów }\end{array}$ & $\begin{array}{l}\text { Zbyt wczesne lub późne przyjazdy kierowców } \\
\text { na załadunek, opóźnienia w przepływie infor- } \\
\text { macji, w produkcji oraz transporcie }\end{array}$ \\
\hline Transport & $\begin{array}{l}\text { Transport generujący niepo- } \\
\text { trzebny, nieprzewidziany koszt }\end{array}$ & $\begin{array}{l}\text { Nieprawidłowo wyznaczone trasy, pomyłki } \\
\text { kierowców }\end{array}$ \\
\hline Zbędny ruch & $\begin{array}{l}\text { Czynności wymuszające zbęd- } \\
\text { ny ruch }\end{array}$ & $\begin{array}{l}\text { Nieodpowiednia wielkość powierzchni stref } \\
\text { w magazynach, nieprawidłowo dobrany sys- } \\
\text { tem zarządzania zapasami i kompletacji, złe } \\
\text { rozmieszczenie towarów }\end{array}$ \\
\hline Zapasy & $\begin{array}{l}\text { Każda aktywność logistyczna, } \\
\text { przez którą należy składować } \\
\text { więcej towarów lub składować } \\
\text { je w nieodpowiednim miejscu }\end{array}$ & $\begin{array}{l}\text { Nieprawidłowy czas dostaw, niepoprawna licz- } \\
\text { ba zamówień, dostaw do złych miejsc, zapasy } \\
\text { nierotujące }\end{array}$ \\
\hline Przestrzeń & $\begin{array}{l}\text { Każde niepoprawne wykorzy- } \\
\text { stanie przestrzeni }\end{array}$ & $\begin{array}{l}\text { Zbyt duże przestrzenie magazynowe, nieopty- } \\
\text { malna wielkość hali produkcyjnej, nieoptymal- } \\
\text { ne wielkości opakowań }\end{array}$ \\
\hline $\begin{array}{l}\text { Braki i ich } \\
\text { naprawa }\end{array}$ & $\begin{array}{l}\text { Wykonywanie tych samych } \\
\text { czynności dwukrotnie lub wię- } \\
\text { cej razy }\end{array}$ & $\begin{array}{l}\text { Błędy i pomyłki zarówno pracowników fizycz- } \\
\text { nych, jak i biurowych: niepoprawnie wypeł- } \\
\text { nione dokumenty, błędne dane o produkcie, } \\
\text { uszkodzenia opakowań, defekty i wady wyro- } \\
\text { bów }\end{array}$ \\
\hline
\end{tabular}

Źródło: opracowanie własne na podstawie: J. Pieklik, Szczupły łańcuch dostaw, „Eurologistics”, nr 6, 2014, s. 18-21. 
Po etapie opracowania propozycji zmian, wymaga się ich wdrożenia. Etap ten zawiera zarówno opracowanie planu wdrożenia zmian oraz jego realizację. To kluczowy proces w dążeniu do uzyskania pożądanych zmian. Podczas wprowadzania koncepcji Lean należy pamiętać, aby nie wykorzystywać pojedynczych narzędzi w danych ogniwach, lecz komplek-sowo podchodzić do łańcucha i udoskonalania go. Przykładami firm, które wdrożyły tę koncepcję, są Nestle, A. Blikle, Bahlsen, Bonduelle, Coca-Cola HBC i Henkel ${ }^{5}$.

\subsection{Strategia Agile - elastyczny lańCuCh dostaw}

Początki strategii Agile (w wolnym tłumaczeniu „agile” = „zwinny”) sięgają 1991 roku$^{6}$. Już wtedy amerykańscy specjaliści zauważyli, iż przedsiębiorstwo w celu zaspokojenia potrzeb klientów musi szybko reagować na ich zmiany. W związku z tym, koncepcja ta odnosi się zarówno do nowoczesnych rozwiązań, lecz również i przede wszystkim do kreatywności i innowacyjności. Zatem łańcuch Agile jest w pełni zorientowany na klienta, co przejawia się nie w dokładniejszym prognozowaniu popytu czy też zwiększaniu zapasów, lecz głównie w realizacji dostaw dopasowanych do aktualnego popytu. Jego głównym zadaniem jest postęp oraz udoskonalanie, szczególnie w warunkach niepewności. Opiera się na zdolności bardzo szybkiego reagowania na potrzeby konsumentów ${ }^{7}$.

Czego tak naprawdę wymaga się od zwinnego łańcucha dostaw? Przede wszystkim jest to otwartość na zmiany. Przedsiębiorstwa muszą być gotowe na podejmowanie ryzyka. Ich pracownicy powinni wciąż poszukiwać, pozyskiwać oraz wdrażać nowe technologie. Dzięki takim cechom zwinne przedsiębiorstwa mają zdolności nie tylko do przewidywania popytu, lecz również kreowania trendów i mody na rynku. Przewagą takiego łańcucha dostaw jest przede wszystkim dostarczanie na rynek skastomizowanego produktu.

W celu zastosowania koncepcji Agile konieczne jest wykorzystanie nowoczesnych systemów informatycznych. Dzięki nim przedsiębiorstwa mają dostęp do danych oraz mogą generować wirtualne łańcuchy dostaw. W przeciwieństwie do konwencjonalnych łańcuchów, mogą one w pełni optymalizować i rozmieszczać zapasy dzięki wymianie danych między wszystkimi ogniwami. Przedsiębiorstwo, które z pełnym sukcesem chce wprowadzić strategię zwinności, musi pamiętać o kilku ważnych aspektach, tzn.:

- każde z ogniw łańcucha musi zrozumieć rolę istnienia tej strategii, a kierownictwo powinno zarządzać całą logistyką w przedsiębiorstwie,

5 http://www.leancenter.pl/aktualnosci/eksperci-branzy-fmcg-pokaza-jak-pomogl-im-lean [03.03.2016].

${ }^{6}$ http://www.log24.pl/artykuly/zagrozenia-lean-manufacturing,1579 [03.03.2016].

7 J. Palewicz, J. Baran, Organizacja łańcucha dostaw w branży odzieżowej, „Logistyka”, nr 6, 2012, s. 533. 
- zadaniem kierowników jest ścisła i bieżąca współpraca z logistykami. Wprowadzanie strategii musi odbywać się już od najniższych szczebli struktury organizacyjnej przedsiębiorstw uczestniczących, gdyż każdy pracownik musi zorientować swoje działania na klienta, wówczas nastawienie i codzienna praca wszystkich zatrudnionych skutkuje widocznością efektów. Wprowadzając koncepcję zwinnego łańcucha dostaw, należy pamiętać o tym, iż najważniejsza jest szybka reakcja na potrzeby zgłaszane przez konsumentów. Co ważne, wymuszenie szybkiej reakcji nie zwalnia $\mathrm{z}$ obowiązku planowania i prognozowania sprzedaży. Istotny jest fakt, iż należy stworzyć plan, a nagłe zamówienia będą wymuszały jego bieżącą modyfikację.

Ze względu na konieczność szybkich zmian oraz potrzebę pełnego zorientowania na klienta, strategię Agile z powodzeniem wprowadzają firmy z branży odzieżowej. Przykładem jest znana na całym świecie sieć sklepów Zara ${ }^{8}$.

\subsection{Porównanie Wybranych Strategi}

Zestawiając metody Lean i Agile, można stwierdzić, że pierwsza z tych koncepcji przedstawia wyszczuplenie, a druga elastyczność łańcucha dostaw. Według M.L. Fishera, sposób doboru strategii i budowania łańcucha dostaw determinowany jest przez rodzaj produktu. Podzielił on wyroby na dwie kategorie związane $\mathrm{z}$ charakterystyką popytu:

- produkty funkcjonalne o przewidywalnym popycie,

- produkty innowacyjne z nieprzewidywalnym popytem ${ }^{9}$.

Łańcuch dostaw tworzony dla artykułów sklasyfikowanych jako funkcjonalne nastawiony jest na efektywną obsługę ustalonego popytu i charakteryzuje się wysokim poziomem wykorzystania potencjału. W tym łańcuchu ważne jest dążenie do zwiększania wskaźnika rotacji oraz zmniejszenia dzięki temu poziomu zapasów. Dodatkowo następuje maksymalizacja wartości dodanej wyrobów.

W przypadku drugiego łańcucha, główny nacisk postawiono na jak najwyższy poziom reakcji, aby zaspokoić niestabilny popyt. Tworzy się rezerwy potencjału, a zapas bezpieczeństwa wyrobów gotowych i komponentów wzrasta. Ponadto, wielką wagę przykłada się do obniżania czasu transportu.

Produkty efektywne powinny przepływać w łańcuchu Lean, natomiast innowacyjne w łańcuchu Agile, co prezentuje Tabela 3.

Podobnie jak Fisher uznali M. Christopher, H. Peck oraz D. Towill, którzy wspólnie zaproponowali rodzaje strategii łańcuchów dostaw w zależności od charakterystyki popytu oraz podaży. Istotę tego rozwiązania przedstawia Tabela 4 .

\footnotetext{
${ }^{8} \mathrm{http}: / /$ galinzhelyazkov.com/wp-content/uploads/2011/09/AgileSupplyChainZaracasestudyanalysis.pdf [03.03.2016].

9 J. Palewicz, J. Baran, op. cit., s. 535.
} 
Tabela 3. Podział strategii według charakterystyki popytu i produktu

\begin{tabular}{|l|c|c|}
\cline { 2 - 3 } \multicolumn{1}{c|}{} & \multicolumn{2}{c|}{ Popyt } \\
\hline Produkty & Zmienny & Stabilny \\
\hline Innowacyjne & Agile & Lean \\
\hline Funkcjonalne & - - - - - - - - - - - - - - - & L----- \\
\hline
\end{tabular}

Źródło: opracowanie własne.

Tabela 4. Podział strategii według charakterystyki popytu i podaży.

\begin{tabular}{|c|c|c|c|}
\hline & & \multicolumn{2}{|c|}{ Charakterystyka popytu } \\
\hline & & Przewidywalny & Nieprzewidywalny \\
\hline \multirow{2}{*}{$\begin{array}{c}\text { Charakterystyka } \\
\text { podaży }\end{array}$} & $\begin{array}{c}\text { Długi łączny czas } \\
\text { dostaw }\end{array}$ & $\begin{array}{l}\text { Lean (2) planowanie } \\
\text { i realizacja }\end{array}$ & Leagile \\
\hline & $\begin{array}{c}\text { Krótki łączny czas } \\
\text { dostaw }\end{array}$ & $\begin{array}{l}\text { Lean (1) ciągłe uzu- } \\
\text { pełnianie zapasów }\end{array}$ & $\begin{array}{l}\text { Agile reagowanie i reali- } \\
\text { zacja }\end{array}$ \\
\hline
\end{tabular}

Źródło: opracowanie własne na podstawie: M. Christopher, A taxonomy for Selecting Global Supply Chain Strategies, „The International Journal of Logistics Management”, No. 2, 2016, s. 283.

Lean (1) określa wykorzystanie ciągłego uzupełniania. Lean (2) rozumiany jest jako Lean Management w czystej postaci. Strategię Agile w przedstawionej sytuacji należy stosować ze szczególnym uwzględnieniem Quick Response, natomiast Leagile to połączenie koncepcji szczupłej oraz zwinnej. Bardzo dobrze podział między tymi dwoma koncepcjami można przedstawić $\mathrm{z}$ wykorzystaniem zasady Pareto (Wykres 1).

W strategii wyszczuplonej $20 \%$ produktów generuje $80 \%$ zapotrzebowania całkowitego, czyli jest to produkcja masowa. Odbywa się według ustalonych prognoz, a zarządzanie zapasami odbywa się centralnie. Jest to wachlarz produktów bardzo strategicznych, gdyż to one pracują w największej mierze na zysk przedsiębiorstwa. Natomiast w koncepcji elastycznej mamy do czynienia z produkcją na zamówienie, $\mathrm{z}$ indywidualnym podejściem do klienta. Zastosowany jest tutaj model ciągłego uzupełniania zapasów, a prognozy sprzedaży są niepewne. 


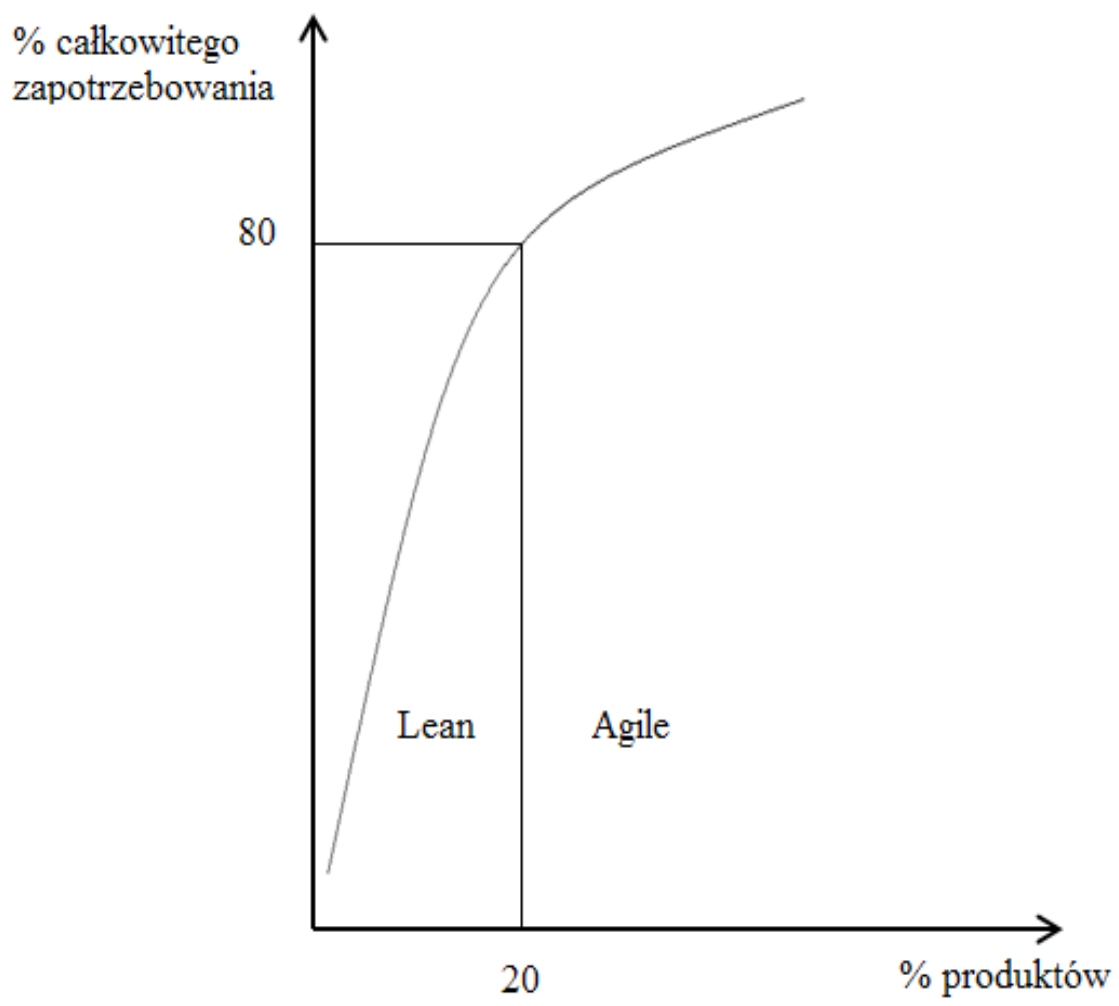

Wykres 1. Podział strategii z wykorzystaniem zasady Pareto

Źródło: opracowanie własne na podstawie: R. Stobiński, Zastosowanie koncepcji zwinno-szczupłego zarządzania produkcja w procesie dopasowania elastyczności i efektywności na przykładzie analizy przypadku firmy z sektora Home Appliance Manufacturing, „Studia Oeconomica Posnaniensia”, Vol. 3, No. 6, 2015.

\subsection{KRYTERIA WYBORU STRATEGII ZARZĄDZANIA LAŃCUCHEM DOSTAW}

Przedstawione wyżej rozważania pozwoliły na opracowanie katalogu kryteriów wyboru odpowiedniej strategii zarządzania łańcuchem dostaw. Tabela 5 zestawia listę kryteriów wraz z omawianymi strategiami.

Tabela 5. Strategie Lean i Agile w aspekcie wybranych kryteriów

\begin{tabular}{|c|c|c|}
\hline Kryterium & Lean & Agile \\
\hline Produkt & Masowy & Skastomizowany \\
\hline Popyt & Przewidywalny & Zmienny \\
\hline Zróżnicowanie produktu & Małe & Duże \\
\hline
\end{tabular}


7. ŁAŃCUCH DOSTAW LEAN CZY AGILE? - JAK EFEKTYWNIE I INNOWACYJNIE ZARZĄDZAĆ....

\begin{tabular}{|c|c|c|}
\hline Kryterium & Lean & Agile \\
\hline $\begin{array}{l}\text { Cykl życia } \\
\text { produktu }\end{array}$ & Długi & Krótki \\
\hline $\begin{array}{c}\text { Cel operacyjny przedsię- } \\
\text { biorstwa }\end{array}$ & $\begin{array}{c}\text { Zaspokojenie rynku } \\
\text { najtaniej jak to możliwe }\end{array}$ & $\begin{array}{c}\text { Jak najszybsza reakcja na zmiany } \\
\text { popytu }\end{array}$ \\
\hline $\begin{array}{c}\text { Priorytet } \\
\text { konsumenta }\end{array}$ & Cena & Dostępność, dopasowanie \\
\hline $\begin{array}{l}\text { Strategia } \\
\text { projektowa } \\
\text { produktu }\end{array}$ & $\begin{array}{l}\text { Minimalny koszt } \\
\text { produkcji }\end{array}$ & $\begin{array}{c}\text { Maksymalne zróżnicowanie } \\
\text { produktu }\end{array}$ \\
\hline Zapasy & $\begin{array}{c}\text { Ciągła minimalizacja } \\
\text { w celu obniżki kosztów }\end{array}$ & $\begin{array}{c}\text { Maksymalna redukcja czasu bez } \\
\text { uwagi na koszty }\end{array}$ \\
\hline Czas realizacji dostawy & $\begin{array}{c}\text { Redukcja czasu bez zwiększania } \\
\text { kosztów }\end{array}$ & $\begin{array}{c}\text { Maksymalna redukcja czasu bez } \\
\text { uwagi na koszty }\end{array}$ \\
\hline $\begin{array}{c}\text { Wybór } \\
\text { dostawców }\end{array}$ & $\begin{array}{l}\text { Oparty na cenie } \\
\text { i jakości }\end{array}$ & $\begin{array}{l}\text { Oparty na elastyczności } \\
\text { i szybkości dostaw }\end{array}$ \\
\hline
\end{tabular}

Źródło: opracowanie własne na podstawie: R. Fabisiak, Kiedy model pasuje do produktu, „Puls Biznesu”, 27.09.2012; S. Konecka, Typologia strategii łańcuchów dostaw, „Logistyka”, nr 5, 2011, s. 8; S. Konecka, Lean and agile supply chain management concepts in the aspect of risk management, „LogForum”, nr 4, 2010, s. 25.

Porównanie tych strategii ujawnia kryteria, jakimi należy się kierować przy wyborze strategii, która będzie dopasowana do łańcucha dostaw. Przedsiębiorstwa powinny odpowiedzieć na kilka podstawowych pytań, dotyczących charakterystyki ich działalności. Tabela 5 potwierdza najważniejsze założenia obu koncepcji, tj. skupienie się na elastyczności w strategii Agile oraz minimalizacji kosztów, jak i czasu w Lean, co zauważalne jest np. przy wyborze dostawców i systemie utrzymywania zapasów.

\section{Podsumowanie}

Przedsiębiorstwa łączą się w łańcuchy dostaw, by jeszcze szybciej i sprawniej obsłużyć klienta, zapewniając mu przy tym najwyższy poziom obsługi, ale również by minimalizować koszty. $\mathrm{Z}$ tych powodów zaistniała potrzeba, by dotychczasowe łańcuchy dostaw udoskonalać i modyfikować tak, by przynosiły oczekiwane korzyści, przy jak najmniejszym zaangażowaniu kapitału. Obserwacja rynku i zachowań klientów pozwoliły wyróżnić dwie strategie: Lean i Agile. Tam, gdzie istnieje produkcja masowa, popyt jest przewidywalny, a prognozy sprzedaży mają duże prawdopodobieństwo, stosowana jest strategia Lean. To, co jest w miarę pewne i znane, należy uszczuplać i modyfikować. Natomiast trudniejszymi do zarządza- 
nia są produkty skastomizowane, dostosowane do klienta indywidualnego. Tutaj istnieje potrzeba odpowiednich narzędzi stosowanych w strategii Agile, czyli pełnej orientacji na klienta, zapewnienia szybkiej reakcji na zmiany zamówień i elastyczności dostaw. Kluczowe w podjęciu decyzji o strategii łańcucha dostaw są: obserwacja i analiza zjawisk na rynku.

\section{Bibliografia}

Christopher M., A taxonomy for Selecting Global Supply Chain Strategies, „The International Journal of Logistics Management", No. 2, 2006.

Fabisiak R., Kiedy model pasuje do produktu, „Puls Biznesu”, 2012.

Fertsch M., Słownik terminologii logistycznej, ILiM, Poznań 2006.

Lambert D., Cooper M., Pagh J., Supply Chain Management: Implementation Issues and Resarge Opportunities, „International Journal of Logistics Management”, Vol. 9, No. 2, 1998.

Konecka S., Lean and agile supply chain management concepts in the aspect of risk management, „LogForum”, nr 4, 2010.

Konecka S., Typologia strategii łańcuchów dostaw, „Logistyka”, nr 5, 2011.

Kruczek M., Żebrucki Z., Doskonalenie struktury łańcucha dostaw z wykorzystaniem koncepcji Lean, „Logistyka,” nr 2, 2011.

Palewicz J., Baran J., Organizacja łańcucha dostaw w branży odzieżowej, „Logistyka”, nr 6, 2012.

Parkes A., Lean Management Genesis, „Management”, Vol. 19, No. 2, 2015.

Piasecka-Głuszak A., Lean Management $w$ polskich przedsiębiorstwach przy wykorzystaniu wybranych narzędzi rozwiazywania problemów - wyniki badań, Praca Naukowa Uniwersytetu Ekonomicznego, Wrocław 2014.

Pieklik J., Szczuply łańcuch dostaw, „Eurologistics”, nr 6, 2014.

Stobiński R., Zastosowanie koncepcji ziwnno-szczupłego zarzadzania produkcja w procesie dopasowania elastyczności i efektywności na przykładzie analizy przypadku firmy z sektora Home Appliance Manufacturing, „Studia Oeconomica Posnaniensia”, Vol. 3, No. 6, 2015.

Tomski P., Królik R., Informatyzacja wybranych procesów logistycznych na przykładzie przedsiębiorstwa hutniczego, ,Logistyka”, nr 6, 2014.

Witkowski J., Zarzadzanie łańcuchem dostaw, PWE, Warszawa 2010.

Wolniak R., Metody i narzędzia Lean Production i ich rola $w$ kształtowaniu innowacji $w$ przemyśle [w:] Innowacje w zarządzaniu i inżynierii produkcji, Oficyna Wydawnicza Polskiego Towarzystwa Zarządzania Produkcją, Opole 2013.

www.leancenter.pl/aktualnosci/eksperci-branzy-fmcg-pokaza-jak-pomogl-im-lean [03.03.2016]. www.log24.pl/artykuly/zagrozenia-lean-manufacturing,1579 [03.03.2016].

www.galinzhelyazkov.com/wpcontent/uploads/2011/09/AgileSupplyChainZaracasestudyanalysis. pdf [03.03.2016]. 
Marta Leszczyńska, Agata Lewandowska

Akademia Morska w Gdyni

Wydział Nawigacyjny

Katedra Geodezji i Oceanografii

ul. Franciszka Sędzickiego 19, 81-374 Gdynia

\section{Wpływ automatyzacji i cyfryzacji na kształtowanie standardów obsługi klienta w usługach transportowych}

\section{WPROWADZENIE}

Rozdział podejmuje temat zmian, które nastąpiły w dziedzinie obsługi klienta na przestrzeni ostatnich lat XXI wieku. Zmiany te związane są z szerokim dostępem do Internetu, lecz również z rozwojem i ogólnym dostępem do automatyki. Nie od dziś wiadomo, że maszyny coraz częściej zastępują ludzi i nie ominęło to też branży przewozowo-transportowej. Klienci, jako najważniejszy czynnik rozwoju i działania gospodarki i marketingu, wyznaczają współczesne trendy w obszarze obsługi klienta oraz wymagają od usługodawców konkretnych rozwiązań. W celu weryfikacji potrzeb potencjalnych klientów oraz maksymalnego uwiarygodnienia treści pracy, została przeprowadzona ankieta na grupie składającej się ze 104 osób, które dobrowolnie odpowiedziały na pytania zadane przez autorki rozdziału. Badanie zostało wykonane za pomocą ankiety elektronicznej umieszczonej na platformie Google Forms (Formularze Google). Ankieta nosiła nazwę tematu artykułu, zawierała kolejno sześć pytań:

- Czy oczekujesz od przewoźnika opcji kupna biletu przez internet? (tak/nie)

- Czy preferujesz kupować bilety przejazdowe przez internet? (tak/nie)

- Którą opcję dostawy przesyłki wybierasz najchętniej:
a) Paczkomaty ${ }^{\oplus}$ InPost,
b) dostawa do domu (Poczta Polska/kurier),
c) odbiór osobisty.

- Czy według Ciebie paczkomaty są potrzebne? (tak/nie)

- Czy korzystasz z usługi internetowego śledzenia przesyłek? (tak/nie)

- Czy według Ciebie możliwość internetowego śledzenia przesyłki jest potrzebna? (tak/nie)

Profil respondentów jest celowo zróżnicowany, aby poznać preferencje wszystkich grup wiekowych, jednakże wszyscy respondenci to osoby regularnie korzystające $z$ Internetu. Ramy wiekowe to 19-50 lat. Kolekcjonowanie wymaganej liczby ponad stu wyników zajęło dwa tygodnie. 
Wyniki ankiety zostały opracowane i przedstawione w tym rozdziale. Kolejne jego części traktują o wybranych aspektach podjętego tematu, od promocji usług do ich sprzedaży. Na podstawie odpowiedzi zostały wysunięte jednoznaczne wnioski, które sugerują usługodawcom podjęcie konkretnych działań wspomagających i podnoszących popularność oraz sprzedaż ich usług.

\subsection{STANDARDY OBSEUGI KLIENTA}

Obsługa klienta to złożony proces interakcji z klientem oraz opieki nad potencjalnym, jak i obecnym klientem, mający na celu usatysfakcjonowanie go i spełnienie jego oczekiwań względem operacji danej firmy, która dla niego tę operację wykonuje. W badanej branży elementy tejże obsługi można podzielić ze względu na stadium wykonania operacji, czyli:

- przedtransakcyjne,

- transakcyjne,

- potransakcyjne.

W pierwszej grupie podziału znajduje się np. polityka danego przedsiębiorstwa, oferta usług i jasne prezentowanie jej potencjalnemu klientowi, sprawne odpowiadanie na pytania zadawane przez zainteresowanych. Drugi sektor obejmuje cykl realizacji usługi w czasie, jakość i szybkość jej zrealizowania. Ostatni etap to ewentualne reklamacje i usługi serwisowe, gwarancje.

W usługach przewozowych jednym z ważniejszych aspektów jest czas. Klientowi zależy na jak najszybszym przewozie dóbr, a co za tym idzie, jest to jeden z głównych standardów, jakie musi spełniać usługodawca. Kolejnym, nie mniej ważnym, jest jakość usługi, która powinna iść w parze z jej szybkością, wyrażająca się przede wszystkim poprzez dowiezienie dobra w stanie nienaruszonym. Mile widziane są także dodatkowe serwisy, m.in. monitorowanie statusu przesyłki online czy zachowanie anonimowości dostawy. Jednak podstawowym standardem - punktem wyjścia do wszelkiego rodzaju ulepszeń - pozostanie jak najkrótszy czas dostawy z zachowaniem przewożonego towaru w stanie niezmienionym na właściwy, podany w liście przewozowym lub innym dokumencie (papierowym czy też elektronicznym) adres odbiorcy.

Obecnie rozwój sieci internetowej stoi na bardzo wysokim poziomie. Dlatego też większość przewoźników decyduje się na korzystanie z niej w celu wzbogacania swojej oferty oraz przybliżania jej klientom. Dzięki cyfryzacji usług firmy mają szansę na rozszerzenie swojej bazy klientów, a także powiadamianie jej kanałami społecznościowym o najnowszych zmianach i promocjach (co z jednej strony przyśpiesza cały proces komunikacji, z drugiej zapewnia większy zasięg). Klient $\mathrm{z}$ kolei może zrobić więcej bez wychodzenia $\mathrm{z}$ domu lub udawania się w przeznaczone do odpowiednich czynności miejsce, co zwiększa jego komfort oraz oszczędza czas. 
Z kolei dzięki automatyzacji - co ma miejsce chociażby w usłudze Paczkomaty InPost - proces nadania oraz odbioru przesyłki, pozbawiony w pewnej mierze czynnika ludzkiego, może być szybszy, wydajniejszy oraz dostosowany do czasu pracy klienta, który często bywa nienormowany i niezgodny z obowiązującym biurowym „od 9:00 do 17:00”. Maszyny pracują bowiem w systemie 24/7, dostosowanym do miejskiego stylu życia i mającym grono zagorzałych zwolenników.

\subsection{SiŁA INTERNETU JAKO CYFRYZACJA USEUG}

Jak zostało przedstawione powyżej, sieć internetowa ma ogromny potencjał, jeśli chodzi o zdobywanie nowych klientów, jak i dbanie o tych już pozyskanych. Jest to również narzędzie umożliwiające skorzystanie $\mathrm{z}$ wielu usług w zaciszu domowym. Aby dowiedzieć się, jak wiele osób preferuje działać w ten właśnie sposób, zadaliśmy pytanie dotyczące zakupu biletów przejazdowych online. Okazuje się, że spośród grupy ankietowanych aż 93\% oczekuje od usługodawcy takiej możliwości, natomiast $85 \%$ preferuje dokonywanie zakupu w ten sposób. Tak liczne potwierdzenia sugerują, że możliwość kupna biletów przejazdowych za pomocą Internetu uważana jest za standard. Wynika z tego również, że jako ludzie staliśmy się po prostu wygodni, ale też mamy mniej czasu, którego nie chcemy tracić na stanie w kolejce po bilet. Dostęp do usług przewoźnika w trybie online uważany jest za oczywistość i absolutne minimum obsługi klienta.

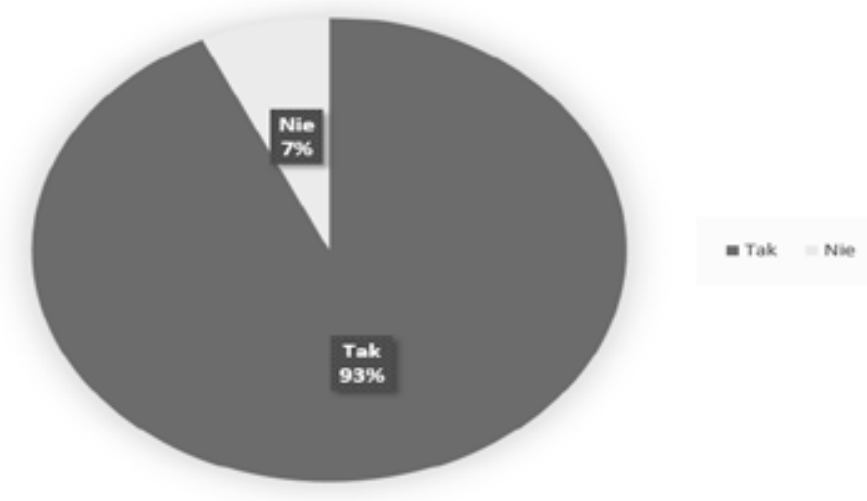

Wykres 1. Odpowiedzi respondentów na pytanie: czy oczekujesz od przewoźnika opcji zakupu biletu przez internet?

Źródło: opracowanie własne.

Oprócz sektora pasażerskiego, sektor towarowy również stał się bardziej nowoczesny w zakresie dostępu do usług. Jedną z nich jest opcja internetowego śledzenia lokalizacji przesyłki. 


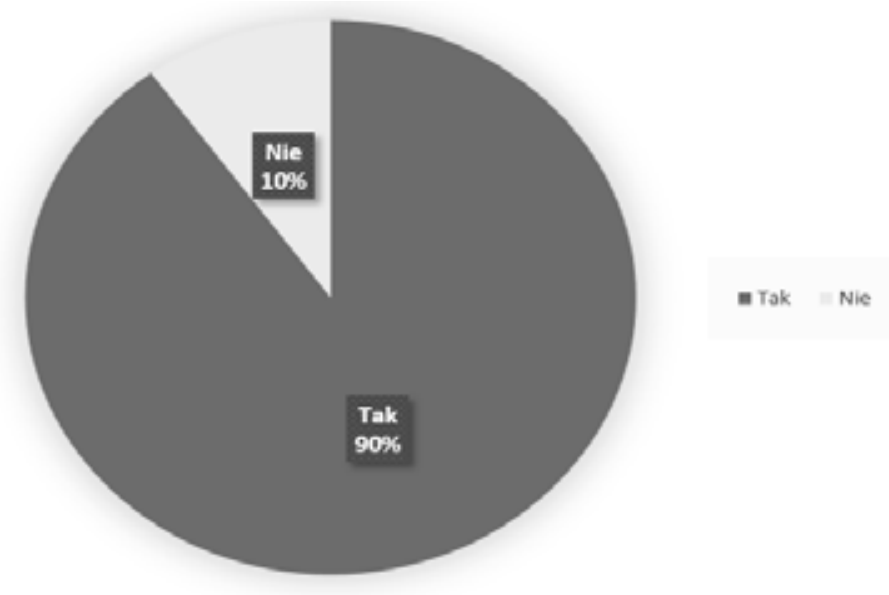

Wykres 2. Odpowiedzi respondentów na pytanie: czy według Ciebie opcja internetowego śledzenia przesyłki jest potrzebna?

Źródło: opracowanie własne.

Pozwala ona zweryfikować, w jakim stadium transportowym się ona znajduje (np. czy wydano ją już z sortowni) oraz w jakim przypuszczalnym czasie możemy się jej spodziewać. Wystarczy wejść na stronę interesującej nas firmy przewozowej i sprawdzić, czy jest tam możliwość namierzenia naszej paczki. Aby nie pomylić przesyłek należy podać numer naszej i gotowe, możemy zobaczyć, w jakiej fazie transportu się znajduje. Firmy, które umożliwiają tę weryfikację to wszystkie najbardziej rozpoznawalne w tej branży, są to m.in. Poczta Polska ${ }^{1}$, Pocztex $^{2}, \mathrm{GLS}^{3}, \mathrm{DHL}^{4}, \mathrm{FedEx}^{5}$, UPS . $\mathrm{Z}$ naszej grupy ankietowanych aż $90 \%$ uważa, że funkcja ta jest potrzebna, a regularnie korzysta z niej $83 \%$ osób. Kolejny przykład na to, jak wiele można zrobić i sprawdzić włączając jedynie komputer - i jak wielu chce korzystać i korzysta $\mathrm{z}$ danej im możliwości.

Jednym $z$ aspektów cyfryzacji usług jest także zapisywanie biletów na smartfonie $\mathrm{w}$ celu pokazania go w razie kontroli. W sektorze transportowym wykorzystuje to m.in. grupa $\mathrm{PKP}^{7}$, dzięki czemu nie dość, że oszczędza się czas i zasoby potrzebne do wydruku biletu papierowego (bądź też, korzystając z jeszcze bardziej anachronicznej metody, zakupu i odbioru biletu w kasie na dworcu), to dodatkowo oszczędza to środowisko naturalne oraz zmniejsza ryzyko zgubienia czy

\footnotetext{
${ }^{1}$ http://emonitoring.poczta-polska.pl/ [06.03.2016].

${ }^{2} \mathrm{http}: / /$ www.pocztex.pl/sledzenie-przesylek/ [06.03.2016].

${ }^{3} \mathrm{https} / / /$ gls-group.eu/PL/pl/sledzenie-paczek/ [06.03.2016].

${ }^{4} \mathrm{http}: / /$ www.dhl.com.pl/sledzenieprzesylkikrajowej/ [06.03.2016].

${ }^{5} \mathrm{https} / / / \mathrm{www}$. fedex.com/apps/fedextrack/?action=track\&cntry_code $=\mathrm{pl}$ [06.03.2016].

${ }^{6} \mathrm{https} / / /$ www.ups.com/WebTracking/track?loc=pl_PL [06.03.2016].

${ }^{7}$ http://www.intercity.pl [06.03.2016].
} 
zapomnienia o bilecie - w końcu telefon to sprzęt obecnie niezbędny, z którym użytkownik bardzo rzadko się rozstaje i o który się troszczy.

\subsection{WYBÓR SPOSOBU DOSTAWY}

Po wypełnieniu wszystkich niezbędnych pól na stronie internetowej z naszymi danymi do przesyłki takimi, jak adres, następuje wybór sposobu dostarczenia danego dobra. W opinii wielu osób jest to wygodne i szybkie rozwiązanie, ponieważ nie wymaga od nas kontaktowania się bezpośrednio z nadawcą, aby go osobiście poinformować o naszej decyzji. W dobie zastępowania ludzi przez maszyny wydawałoby się, że najchętniej wybieranym sposobem dostawy okażą się Paczkomaty ${ }^{\bullet}$ InPost. Na pierwszym miejscu uplasowała się jednak dostawa pod wyznaczony adres zamieszkania, tzw. „do rąk własnych”.

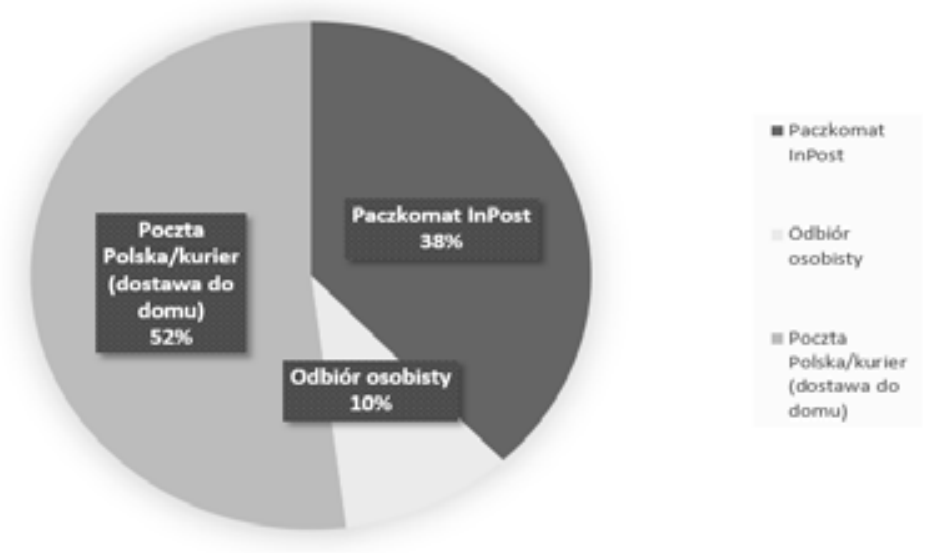

Wykres 3. Odpowiedzi respondentów na pytanie: którą opcję przesyłki najchętniej wybierasz? Źródło: opracowanie własne.

Jak można się domyślić, jest to wygodne i nie wymagające ruchu rozwiązanie, a ankietowani lubią wygodę. Pozostaje jednak kwestia zaufania dostarczycielowi, niejednokrotnie bowiem w sieci pojawiały się filmy, na których widać, w jak karygodny sposób traktowana jest paczka.

Co w przypadku, kiedy czekamy na ważną dla nas przesyłkę, lecz nie ma nas w domu? Co gorsza, żadna bliska bądź zaufana osoba nie może odebrać jej w naszym imieniu? W tej sytuacji najlepiej sprawdzają się Paczkomaty ${ }^{\circledR}$ InPost, które w wyniku naszej ankiety znalazły się na drugim miejscu pod względem najczęściej wybieranego sposobu odbioru przesyłek. 


\subsection{Praktyki firmy InPost}

Obecnie oczekuje się od usługodawcy nie tylko obsługi o odpowiednio wysokiej jakości i na poziomie, ale również o określonym charakterze. Większość klientów nie wymaga absolutnej powagi, woląc podejście lekkie, wręcz żartobliwe, niepozbawione jednak profesjonalizmu. InPost jest idealnym tego przykładem. Prowadzony przez nich blog blog.paczkomaty.pl wypełniony jest tekstami, dzięki którym zostaje nawiązany bliski i bezpośredni kontakt z klientem. Ten sam styl starają się utrzymywać na prowadzonym przez siebie fanpage'u InPost - Paczkomaty, Listy, Kurier. Można na nim znaleźć wiele pozytywnych historii o tym, jak usługa Paczkomatów sprawdziła się doskonale. InPost odpowiada na nie z uśmiechem i wyraźnym zaangażowaniem w dobro klienta. Nadaje to całej instytucji bardziej ludzki wymiar. Przyjazna obsługa to dla InPostu standard, do którego powinni dążyć nie tylko pozostali operatorzy pocztowi, ale i ogół reprezentantów firm.

Kochani, dlaczego zamkonęlície paczkomat w Gdyni na Witominie, prry ulicy Naucrycielskiej? (v) Byi mi tak bardzo po drodzo, tam odbieratam o 23 swoją kopie Wiedźmina 3. Zdąbyam siẹ do niego przywizzad przez rok mieszkania w Gdyni, a Wy mi robicie taki afront (4)

InPost - Pacrkomaty, Llsty, Kurler 14.09 .201501 .27

Agato, serce boli, gdy czylamy takie zgloszenia: Najchøtriej widzielbyimy Paczkomaty na kazdym skwerze. alel, ulicy i deptaku. Jednak czasami skla wyzsza - partner rorwiqzuje umowę albo maszyna nie przynosi dochodu - i musimy delikwenta relokowab. Mamy nadzieje, ze mimo wszystke będziesz nas lubic....

Jestem dode wyrozumiala, i mimo tego welaz Was kocham - zostal mi jeszcze Paczkomat na ulicy Morskiej, przy Kauflandzie, jedymy obecnie mi po drodze do domu z uczelni. Zatem, nie robbcie mi tego i chociaz tamten pozostawcio.

Tak w ogóle, skorzystam z okariji i powiem Wam, be odwalacio kawat dobrej roboty. Idea Paczkomatów dla kogos z nienormowanym czasem bycia w domu - czyli np. każdy student - to cos wtpanialego. Doceniam za kaźdym razem, gdy Pan Paczkomat pyta, cry nastepnym razem sprobujemy szybciej (jakkolwiek to nie brzmi). Dzjeki za odzenw i postarajcie się Ltrzymac chociad ten Paczkomat na Morskiej (bo przy CH Batory nie ma gdzie zaparkowad (4) ) Poadrawiam Was ciepto, Agata

InPost - Paczkomaty, Listy, Kurler

Witaj ponownie. Cala prryiemnobb po naszej stronio, a do Paczkomatu na Morskiej jak będrie potrzeba się przykujemy (2) Chociaz mamy nadzieje. ze nie bedzie... Pozdrawiamy

Rysunek 1. Zrzut ekranu z rozmową z przedstawicielami firmy InPost na portalu Facebook Źródło: facebook.com/messages [14.09.2015]. 
Podstawowym założeniem usługi pocztowej Paczkomaty ${ }^{\circledast}$ InPost jest zniesienie ograniczeń czasu i miejsca dla odbiorcy paczki. W XXI wieku trudno o siedzenie w domu i czekanie na kuriera, kiedy studia bądź praca naglą, dzieci trzeba zawieźć lub odebrać i w konsekwencji nikogo nie ma na miejscu w chwili, gdy dostawca dzwoni do drzwi. Paczkomaty pozwalają na zamawianie produktów za pośrednictwem Internetu w sposób przede wszystkim wygodny. Koniec ze stresowaniem się, że kurier przyjedzie do domu w godzinach pracy (sporadycznie zdarza się to po godzinie 17:00). Koniec z przepraszającym spojrzeniem, gdy portier w biurowcu kolejny raz odebrał paczkę za nas. Obecnie rozwiązaniem tego problemu są Paczkomaty. Umożliwiają one odbiór przesyłki poza miejscem zamieszkania, w miejscu publicznym. Po wpisaniu swojego numeru telefonu oraz otrzymanego kodu otwiera się odpowiednia skrytka - i paczka jest gotowa do odbioru - 24h na dobę, 7 dni w tygodniu, najczęściej po drodze z pracy lub z zakupów. Cały proces zajmuje mniej niż 30 sekund, szczególnie przy wykorzystaniu wygenerowanego przez system kodu $\mathrm{QR}^{8}$. Nie wymaga on człowieka na stanowisku, proces został bowiem zmechanizowany. Dodatkowe zalety usługi to konkurencyjna cena (rzędu 10 PLN) oraz formuła dostawy $\mathrm{D}+1^{9}$.

Paczkomaty ${ }^{\circledast}$ InPost są obecnie dostępne w 21 krajach na czterech kontynen$\operatorname{tach}^{10}$. Jest to polski produkt, który podbił światowe rynki, pokazując ludziom na całym globie, jak inaczej można prowadzić dostawę.

\subsection{INNOWACJE W OBSEUDZE KLIENTA KOMUNIKACJI MIEJSKIEJ}

Pasażer komunikacji miejskiej także jest klientem. Obecny świat oferuje rozwiązania, które ułatwiają mu podróżowanie w sposób szybki, punktualny i komfortowy. Istnieje szereg narzędzi, umożliwiających dobranie odpowiedniego środka transportu, $\mathrm{z}$ uwzględnieniem czasu przejazdu, dotarcia z przystanku początkowego do przystanku docelowego. Jednym $z$ nich, obecnym na polskim rynku, jest serwis jakdojade.pl, prowadzony od 2008 roku przez firmę CITY-NAV $\mathrm{z}$ siedzibą w Poznaniu ${ }^{11}$. Można $\mathrm{z}$ niego korzystać za darmo zarówno poprzez przeglądarkę, jak i aplikacje mobilne na systemy Android, iOS oraz Windows Phone (istnieją płatne wersje premium aplikacji, umożliwiające m.in. zapisanie rozkładów w wersji offline).

Serwis to nic innego jak wyszukiwarka połączeń komunikacji miejskiej, uwzględniająca zmiany $\mathrm{w}$ rozkładach $\mathrm{w}$ czasie rzeczywistym, przesiadki i inne

\footnotetext{
${ }^{8}$ Kod QR, ang. QR Code, Quick Response Code, to rodzaj kodu kreskowego, pozwalającego na zapisanie dużej ilości danych. Jego zaletami są możliwość zapisania dużej ilości znaków (4 296 znaków alfanumerycznych) oraz szybkość odczytu danych za pomocą odpowiednich skanerów, od $2000 \mathrm{r}$. standard ISO.

${ }^{9} \mathrm{D}+1$ - dostawa następnego dnia po nadaniu.

${ }^{10} \mathrm{https} / / / \mathrm{b} 2 \mathrm{~b}$. paczkomaty.pl/pl/poznaj-paczkomaty/sukces-made-in-poland [05.03.2016].

${ }^{11} \mathrm{http} / / /$ city-nav.com [05.03.2016].
} 
aspekty poza samą jazdą. Usługa jest dostępna dla 22 największych polskich miast, w tym dla Trójmiasta, Górnośląskiego Okręgu Przemysłowego czy Bydgoszczy. Uwzględnia wszystkie dostępne na danym terenie środki komunikacji publicznej i jest doskonałą alternatywą dla korzystania ze zwykłych rozkładów jazdy na stronie przewoźnika. Wszystkie informacje dostępne są w jednym miejscu, a algorytm dobiera połączenia zgodnie z potrzebami klienta - wystarczy smartfon z dostępem do Internetu, obecnie standard. Dostęp jest możliwy $24 \mathrm{~h}$ na dobę, $7 \mathrm{dni}$ w tygodniu, w każdym miejscu Polski. Można łatwo zaplanować podróż z wyprzedzeniem lub sprawdzać połączenia na bieżąco. Przy $52 \mathrm{mln}$ odsłon i $3 \mathrm{mln}$ unikalnych użytkowników każdego miesiąca serwis jakdojade.pl pokazuje inne spojrzenie na rozkłady jazdy i podróżowanie komunikacją miejską. To rozwiązanie zarówno dla świeżych, jak wieloletnich mieszkańców miast, ludzi aktywnych, lubiących wygodę i swobodny dostęp do danych.

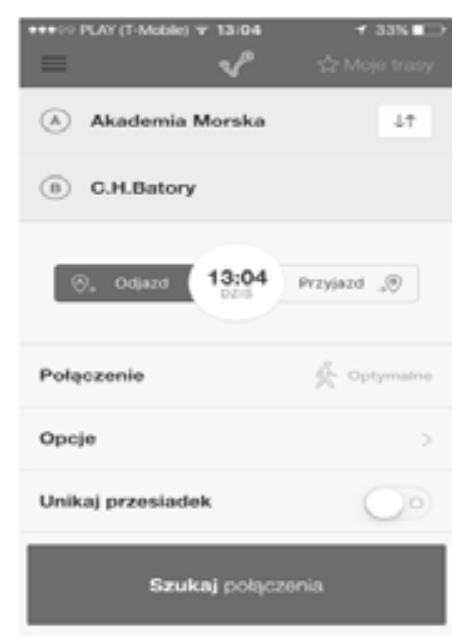

Rysunek 2. Ekran wyboru punktu początkowego i docelowego, aplikacja JakDojadę, iOS, wersja 2 Źródło: Aplikacja JakDojadę, iOS, wersja 2.1 [29.12.2015].

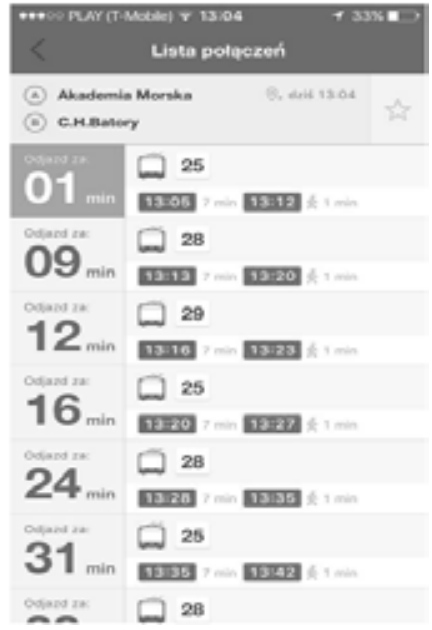

Rysunek 3. Ekran dostępnych połączeń, aplikacja JakDojadę, iOS, wersja 2.1 Źródło: Aplikacja JakDojadę, iOS, wersja 2.1 [29.12.2015].

Punkty można dobrać na kilka sposobów: używając systemu POI, dokładnego adresu bądź nazwy przystanku. Istnieje możliwość modyfikacji parametrów wyszukiwania w celu wykluczenia konkretnych środków transportu, linii przewozowych, oznaczenia preferowanego połączenia, zależnie od potrzeb - szybkość bądź wygoda - a także uniknięcia przesiadek. Wyszukiwarka ukazuje wszystkie dostępne połączenia zarówno bezpośrednie, jak i z przesiadkami. Podaje godzinę odjazdu wraz z czasem pozostałym do tej chwili, godzinę przyjazdu na przystanek docelowy oraz czas, który musi zostać przeznaczony na podróż pieszo. Gdy do odjazdu pozostaje 5 minut i mniej, okienko podświetla się na czerwono, co zwiększa zauważalność. 
Po wybraniu konkretnego połączenia, ukazują się jego szczegóły, takie jak przystanki po drodze, a także trasa połączenia naniesiona na mapę. Z tego ekranu można rozpocząć nawigację do przystanku początkowego, ustawić przypomnienie o odjeździe, a także - w niedalekiej przyszłości - zakupić bilet na połączenie, płacąc za niego przelewem.
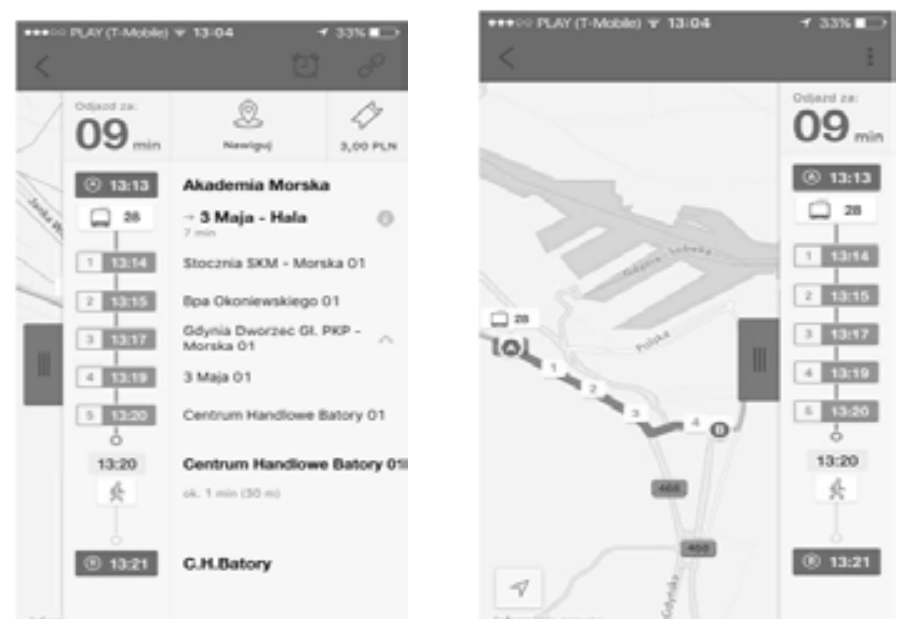

Rysunek 4. Szczegóły danego połączenia, aplikacja JakDojadę, iOS, wersja 2.1 Źródło: Ibidem.

Innym serwisem oferującym podobne usługi, tym razem lokalnym, jest trójmiejski TRISTAR. Jest on jednym z elementów Inteligentnego Systemu Transportowego działającego na terenie Gdańska, Gdyni i Sopotu. Umożliwia on sprawne i efektywne zarządzanie infrastrukturą transportową oraz sprawną obsługę podróżnych. Zdecydowano się na zastosowanie inteligentnego zarządzania ruchem z uwagi na duże zatłoczenie ulic, pogarszające się warunki podróżowania środkami transportu zarówno indywidualnego, jak i zbiorowego.

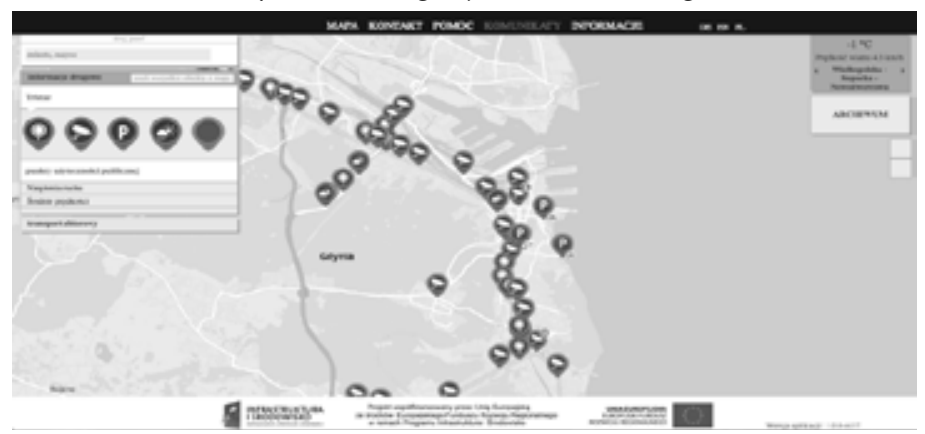

Rysunek 5. Zrzut ekranu z portalu tristar.gdynia.pl, widok ogólny

Źródło: https://tristar.gdynia.pl/pages/public/detailed_map.xhtml [09.01.2016]. 
Portal tristar.gdynia.pl oferuje wgląd w ruch samochodowy na terenie Trójmiasta, ukazując jego natężenie, średnią prędkość aut na danych odcinkach, a także pokazuje w czasie rzeczywistym wszystkie inteligentne elementy systemu, takie jak tablice zmiennej treści, dotyczące zarówno transportu zbiorowego, jak i ogólne, z czasami przejazdu do poszczególnych dzielnic miast.

Portal oferuje także dostęp do rozkładów komunikacji miejskiej Trójmiasta, umożliwia śledzenie połączeń w czasie rzeczywistym, a także wyszukiwanie i planowanie podróży na podstawie adresów punktu początkowego i punktu docelowego.

Zarówno strona internetowa, jak i sam system są dość nowe - inauguracja odbyła się 19 listopada $2015 \mathrm{roku}^{12}$, dlatego też portal nie zawsze działa jak należy, potrafi się zawieszać (co widać na poniższym zrzucie ekranu), dodatkowo ma dość ograniczoną funkcjonalność w porównaniu do jakdojade.pl, brakuje mu także aplikacji mobilnej. Jednak obecnie inteli-gentne zarządzanie ruchem za pomocą systemów pokroju TRISTARA stało się standardem, ułatwiając obsługę klientów miejskiej sieci ulicznej oraz komunikacji miejskiej. Osobiście uważamy tablice przystankowe za wielce przydatne, działają one poprawnie oraz są szybszym i wygodniejszym sposobem na sprawdzanie najbliższych połączeń, będąc już na przystanku niż tradycyjne, papierowe rozkłady jazdy. Liczymy na to, że za parę lat takie tablice pojawią się na każdym przystanku autobusowym, trolejbusowym, tramwajowym i kolejowym Trójmiasta.

\subsection{IM TANIEJ, TYM WYŻEJ W WYNIKACH WYSZUKIWANIA}

Każdy klient pragnie, jak najwięcej zaoszczędzić na swojej podróży. Jak tego dokonać? Kiedy jest się nowicjuszem w szukaniu sposobu przemieszczania się i wybieraniu tego najbardziej ekonomicznego ze wszystkich możliwych, z pomocą przychodzą wyszukiwarki ewaluujące dany transport zgodny $\mathrm{z}$ datą, na którą planujemy wyjazd. Jest wiele takich platform, najbardziej popularne to: mlecznepodróże.pl, latamy.pl, tanie-loty.pl, fly4free.pl, esky.pl, tanie-bilety-autobusowe.pl. Po wejściu w jedną z witryn ukazują się pola dotyczące miejsca wyjazdu i dojazdu oraz ich dat. Wyszukiwarki te są sprzężone ze stronami niektórych przewoźników, spośród ofert których wybierają te najbardziej opłacalne. Często okazują się to być przejazdy z tzw. przesiadkami, ponieważ system łączy kilka najtańszych opcji tak, aby dostosować je do naszych potrzeb. Przykładowo przelot bezpośrednio z Gdańska do Monachium trwa ok. 1,5 h, podczas gdy lot z jedną przesiadką wraz z czekaniem na drugi samolot trwa ok. 4 h. Jeśli chodzi o cenę, bezpośredni przelot okazał się o 200 PLN droższy. Oczywiście, zależnie od przypadku, różnica między lotem z przesiadkami a bezpośrednim zmienia się.

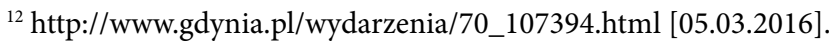


Dla wszystkich rodzajów transportu znajdzie się tego typu wyszukiwarka tanich połączeń. W trakcie szukania najdogodniejszego połączenia, napisane jest, że „system przeszukuje miliony kombinacji”. Nic zatem dziwnego, że przedstawienie wyników wyszukiwania poprzedza niekiedy długi czas oczekiwania, lecz, jak zapewne większość klientów się zgodzi, warto poczekać.

\subsection{INTERNET JAKO ŹRÓDLO KONKURENCJI}

Mimo spełniania ważnych funkcji marketingowych dla obecnych firm przewozowo-transportowych, sieć internetowa może okazać się ich największym wrogiem. W niej właśnie tworzą się i wchodzą w życie nowe pomysły na transport, które nie są konkretną firmą mającą własnych pracowników, lecz rodzajem forum internetowego lub aplikacji mobilnej zrzeszającej osoby zainteresowane. Nie tak dawno w przestrzeni publicznej pojawił się Uber ${ }^{13}$. Odwiedzając stronę internetową poświęconą temu przedsiębiorstwu, każdy może zarejestrować się jako kierowca. Następnie wszystko polega na zamówieniu samochodu - wraz kierowcą, będącym prywatnie użytkownikiem swojego auta - za pomocą Internetu lub SMSa. Nie trudno zauważyć, że stało się to poważną konkurencją dla taksówkarzy. Ponadto wiele osób nie jest pewnych swojego bezpieczeństwa podczas jazdy, jako, że aby być przedstawianym jako kierowca w owej aplikacji, nie trzeba posiadać licencji taksówkarza. Stwarza to zatem pytanie, czy absolutnie każdy posiadający prawo jazdy może zostać kierowcą Ubera? Faktem jest, że $\mathrm{w}$ pierwszych miesiącach działania aplikacji w danym mieście, stosowane są tzw. ceny dumpingowe. Oznacza to, że cena za kilometr może być nawet do dwóch i pół razy niższa niż w przypadku klasycznej taksówki. Ponadto, jeśli chodzi o sprawę podatków, kierowcy zarejestrowani $\mathrm{w}$ Uber powinni odprowadzać podatek dochodowy oczywiście w kraju, w którym jeżdżą. Sam Uber natomiast nie posiada placówek w większości krajów, w których działa ${ }^{14}$. Znajdują się one w państwach o niskich podatkach. Faktem jest zatem to, że ani złotówka z przychodu firmy nie zostaje przeznaczona na rozwój Polski.

Innym przykładem przedsięwzięcia powodującego utratę klientów przez przewoźników jest BlaBlaCar ${ }^{15}$. Idea polega na zmniejszaniu kosztów przejazdu samochodem poprzez dobór współtowarzyszy jazdy, którzy ponoszą ustaloną z kierowcą część kosztów paliwa. Jest to sprawiedliwe, ponieważ nie jest to traktowane jako zarobek a jako pomaganie sobie nawzajem. Aby skorzystać $\mathrm{z}$ możliwości dołączenia się do przejazdu bądź zaoferować wolne miejsca w swoim samochodzie, należy zarejestrować się na witrynie internetowej. Następnie szukamy

\footnotetext{
${ }^{13}$ www.uber.com [06.03.2016].

${ }^{14} \mathrm{http}: / /$ www.spidersweb.pl/2015/01/uber-w-polsce-legalnosc.html [06.03.2016].

${ }^{15}$ www.blablacar.pl [06.03.2016].
} 
interesującej nas trasy, kontaktujemy się z wybranym użytkownikiem i ustalamy szczegóły wycieczki. Zależnie od interesującego nas kursu, to rozwiązanie może okazać się bardziej ekonomiczne niż tradycyjne środki transportu.

\section{Podsumowanie}

$\mathrm{W}$ rozdziale zostały poruszone wybrane kwestie dotyczące automatyzacji i cyfryzacji danych usług branży przewozowo-transportowej. Na przykładzie kilku usługodawców zostały przybliżone niektóre aspekty procesów promocji, wyboru usług, ich sprzedaży, a w końcu ich dostarczania, wiążące się z nieustającym postępem technologicznym w tej dziedzinie gospodarki. Zostały również przedstawione pomocne dla potencjalnego klienta aplikacje, dzięki którym poprzez swój telefon lub komputer może on zaplanować całą podróż z najmniejszymi szczegółami.

Opracowane wyniki ankiety jasno pokazują, że zostały ustalone pewne niepisane standardy w obszarze obsługi klienta. Pierwszym z nich jest dostęp do informacji i oferty usług danej firmy poprzez stronę internetową, która okazuje się być wizytówką danego przedsiębiorstwa. Kolejnym wymaganiem klientów jest możliwość internetowego zakupu tych usług, a co za tym idzie - również płatności i wyboru dostawy. Można przypuszczać, że postępująca automatyzacja w zakresie dostaw wyprze całkowicie element ludzki, tak się jednak nie stało. Kurierzy pozostają pożądaną jednostką dostawczą, lecz z uwagi na rozwój technologii może się to zmienić w przyszłości.

\section{Bibliografia}

www.intercity.pl [06.03.2016].

www.polskibus.pl [06.03.2016].

www.facebook.com/PolskiBus [06.03.2016].

www.uber.com [06.03.2016].

www.spidersweb.pl/2015/01/uber-w-polsce-legalnosc.html [06.03.2016].

www.blablacar.pl [06.03.2016].

www.facebook.com/blablacar [06.03.2016].

www.emonitoring.poczta-polska.pl/ [06.03.2016].

www.pocztex.pl/sledzenie-przesylek/ [06.03.2016].

www.dhl.com.pl/sledzenieprzesylkikrajowej/ [06.03.2016].

www.inpost.pl/pl/pomoc/znajdz-przesylke [06.03.2016].

www.fedex.com/apps/fedextrack/?action=track\&cntry_code=pl [06.03.2016].

www.gls-group.eu/PL/pl/sledzenie-paczek [06.03.2016].

www.ups.com/WebTracking/track?loc=pl_PL [06.03.2016].

www.b2b.paczkomaty.pl/pl/poznaj-paczkomaty/sukces-made-in-poland [05.03.2016].

www.city-nav.com [05.03.2016].

www.gdynia.pl/wydarzenia/70_107394.html [05.03.2016]. 
Mgr Patryk Mikołajczyk

Uniwersytet Łódzki

Katedra Logistyki

ul. Matejki 22/26, 90-237 Łódź

\section{Rozwój produktów polskiego przemysłu elektromaszyno- wego na przykładzie przedsiębiorstwa PESA Bydgoszcz S.A.}

\section{WPROWADZENIE}

Coraz częściej można przeczytać lub usłyszeć o sukcesach, jakie odnoszą polskie przedsiębiorstwa na rynku krajowym, jak i międzynarodowym. Spostrzeżenie dotyczy różnych branż, bowiem nie tylko dobra konsumpcyjne z kraju nad Wisłą potrafią być hitem eksportowym, ale również coraz częściej złożone, wysokoprzetworzone produkty made in Poland zdobywaja powszechne uznanie. Interesującym zagadnieniem jest obserwacja procesów powstawania polskich konstrukcji, które z powodzeniem konkurują ze swoimi zagranicznymi odpowiednikami.

Celem niniejszego rozdziału jest charakterystyka tego zjawiska na przykładzie tramwajów produkowanych przez PESA Bydgoszcz S.A. Dodatkowo podjęto próbę odpowiedzi na pytanie: jaką część swojego sukcesu, polskie przedsiębiorstwa, które niewątpliwie go odniosły, zawdzięczają rozwojowi nauk o zarządzaniu produkcją, w tym logistyki?

W częściach pierwszej i drugiej przeprowadzono rozważania dotyczące rozwoju produktu, prezentując podstawowy dorobek naukowy na temat istoty omawianego procesu. Trzecia część koncentruje się na porównaniu podstawowych cech sztandarowych produktów oferowanych przez PESĘ. Następnie przeprowadzono analizę procesu ich wytwarzania, m.in. opisano proces dostawy nowych tramwajów Swing dla MPK Łódź. W podsumowaniu ujęto najważniejsze wnioski.

Rozdział powstał na bazie publikacji z zakresu logistyki i marketingu, dostępnych informacji na temat działalności PESA Bydgoszcz S.A., a także własnych doświadczeń i przemyśleń autora jako użytkownika tramwajów Tramicus i Swing.

\subsection{CZyM Jest ROzWój PRODUKTU?}

Produkt definiowany jest jako wyrób, towar, usługa lub informacja, których zasadnicze cechy można rozpatrywać na dwóch płaszczyznach: materialnej i niematerialnej. W jakiejkolwiek postaci by nie występował, jego głównym celem jest zaspokojenie potrzeb konsumenta ${ }^{1}$. Każdy produkt charakteryzuje się tzw. cyklem

${ }^{1}$ Słownik terminologii logistycznej, red. T. Janiak, Instytut Logistyki i Magazynowania, Poznań 2006. 
życia określającym jego funkcjonowanie na rynku. Wyróżnia się następujące fazy cyklu życia produktu: opracowanie, wprowadzenie, wzrost, dojrzałość, spadek. Wraz $\mathrm{z}$ upływem czasu, popyt na dane dobro zmienia się, co znajduje przełożenie na zyski przedsiębiorstwa je wytwarzającego. Zasadniczo, każdy produkt w pewnym czasie osiąga fazę spadku, co oznacza, że jego dotychczasowa formuła oferowana klientom wyczerpała się. $\mathrm{W}$ takim momencie pojawia się problematyka zmiany, zaoferowania konsumentom czegoś wyróżniającego się nowym podejściem. Są różne sposoby dokonywania takiej rynkowej rewolucji. Możliwe jest m.in. zakupienie konkurencyjnego przedsiębiorstwa lub jego własności intelektualnej w postaci patentu bądź licencji, co umożliwia poszerzenie dotychczasowej oferty.

Nieco bardziej wymagająca jest druga opcja polegająca na wykreowaniu własnym nakładem zasobów produktu charakteryzującego się innowacyjnością². Pojęcie to wymaga wytłumaczenia. Powołując się na określenie opracowane wspólnie przez OECD i Eurostat, innowacja jest „wdrożeniem nowego bądź znacząco udoskonalonego produktu lub procesu, nowej metody marketingowej lub nowej metody organizacyjnej w praktyce gospodarczej, organizacji miejsca pracy lub stosunkach z otoczeniem"3. Warto zatem zapoznać się z pojęciem innowacji produktowej. Ta kategoria oznacza umieszczenie na rynku zupełnie nowego produktu lub usługi bądź ich udoskonalonej wersji. Elementem wyróżniającym innowacyjny produkt względem poprzednika może być: zmiana materiału wykorzystywanego do produkcji, nowe podzespoły bądź komponenty, odmienny sposób obsługi, zwiększona wydajność, inne parametry techniczne czy dodatkowe możliwości.

Pojęcie innowacji produktowej często jest zamiennie stosowane $\mathrm{z}$ terminem nowy produkt, który trudno jednoznacznie zdefiniować i zinterpretować. Co istotne, wskazane wyżej określenia są jednocześnie celem i efektem procesu określanego jako rozwój nowego produktu ${ }^{5}$. W dalszej części rozważań używane będzie skrótowo sformułowanie rozwój produktu.

\subsection{NA CZYM POLEGA ROZWóJ PRODUKTU?}

Proces zdefiniowany w poprzedniej części niniejszego rozdziału to działalność z pogranicza logistyki i marketingu. Znaczenie marketingu w przedmiotowej materii przejawia się przede wszystkim na początku procesu, który jest inicjowany w wyniku gromadzenia, przetworzenia i analizy danych docierających z rynku oraz na jego końcowym etapie, kiedy następuje komercjalizacja nowego produ-

\footnotetext{
${ }^{2}$ G. Armstrong, P. Kotler, Marketing. Wprowadzenie, Wolters Kluwer, Warszawa 2015, s. 377-385.

${ }^{3}$ https://www.nfosigw.gov.pl/download/gfx/nfosigw/pl/nfoopisy/1406/5/8/innowacyjnosc_-_ definicja_i_zasady_oceny_2.11.2015.pdf [30.03.2016].

${ }^{4} \mathrm{~K}$. Klincewicz, Dyfuzja możliwości. Jak odnieść sukces w komercjalizacji nowych produktów i usług, Wydawnictwo Naukowe Wydziału Zarządzania Uniwersytetu Warszawskiego, Warszawa 2011, s. 9-10.

${ }^{5}$ I. Rutkowski, Rozwój nowego produktu. Metody i uwarunkowania, PWE, Warszawa 2007, s. 15.
} 
ktu i w dalszych etapach jego cyklu życia. Logistyka odpowiada za centralną część obsługi procesu rozwoju produktu. Jej rolą jest integracja procesowa obszarów odpowiedzialnych za planowanie, wykonywanie, sterowanie i kontrolowanie przepływów związanych z rozwojem produktu. Infrastruktura logistyczna umożliwia zaangażowanie odpowiednich zasobów w procesie produkcyjnym, magazynowym oraz dystrybucyjnym. Dodatkowo logistyka, jako dziedzina ściśle nastawiona na optymalizację kosztów, budowanie wartości produktów oraz wzrost efektywności w poszczególnych obszarach łańcuchów dostaw, stanowi inspirację do wprowadzania zmian asortymentowych.

Rozwój produktu jest procesem niezwykle złożonym, obejmującym szereg działań, zmierzających do powstania i ekonomicznego wykorzystania przez przedsiębiorstwo innowacji produktowej w drodze włączenia go do obrotu gospodarczego. Wśród działań można wyróżnić: wybór strategii rozwoju związany z definiowaniem czynników sukcesu, rozróżnienie i zastosowanie odpowiedniego modelu rozwoju, opracowanie metod strukturyzacji i programowania procesu, zadania z zakresu kontroli przebiegu procesu, zarządzanie ryzykiem, a także pomiary zdolności przedsiębiorstwa w zakresie wdrażania i funkcjonowania procesu ${ }^{6}$. Poniżej nastąpi krótkie omówienie wymienionych działań.

Zdaniem I. Rutkowskiego, strategiami rozwoju produktu są kierunkowe sposoby radzenia sobie z problemami, które występują przy okazji projektowania, rozwoju oraz komercjalizacji produktów ${ }^{7}$. Ze względu na wybrane kryterium można wyodrębnić wiele strategii. Podziałowi strategii służą m.in. takie wyróżniki, jak: podstawa metodologiczna podmiotów procesu, stopień zaprogramowania działania, wzorzec poszukiwań. Jednym z autorów, zajmujących się badaniem strategii, jakie przedsiębiorstwa mogą stosować przy wdrażaniu procesów dedykowanych rozwojowi produktu, był H.I. Ansoff. W przekonaniu niniejszego autora, strategie rozwoju nowych produktów są silnie związane z pojęciem dywersyfikacji, która może przyjmować różne postaci. Dokonał on podziału na dywersyfikację zewnętrzną i wewnętrzną. Pierwsza $\mathrm{z}$ nich sprowadza się do pozyskiwania innowacji $\mathrm{w}$ drodze eksploatacji podmiotów pierwotnie niemających związków z przedsiębiorstwem. Chodzi tu o akwizycję nowych firm, pojedynczego produktu bądź całych linii produktów, zakup patentów, licencji, a także konsultacje ze specjalistycznymi podmiotami zewnętrznymi. Natomiast dywersyfikacja wewnętrzna angażuje zasoby należące do przedsiębiorstwa. W jej skład wchodzą takie strategie, jak: obrona pozycji rynkowej, zdobywanie rynku dla nowego produktu, przejmowanie segmentu rynku, zajmowanie pozycji innowatora lub naśladowcy i oparcie na nowych zastosowaniach oraz transferze dotychczasowych technologii ${ }^{8}$.

${ }^{6}$ Ibidem, s. 5-6.

${ }^{7}$ Ibidem, s. 39.

${ }^{8}$ Ibidem, s. 44. 
Zasadniczo wyodrębnia się dwa modele rozwoju nowych produktów: sekwencyjny oraz zintegrowany. Proces oparty na modelu sekwencyjnym przypomina historyczną organizację produkcji w manufakturach. Rozwijany produkt $\mathrm{w}$ toku procesu jest przekazywany od jednego działu do drugiego w odgórnie uporządkowany sposób. Nad każdym etapem procesu czuwa kierownik działu, w którym aktualnie produkt się znajduje i nie ma osoby wyznaczonej do holistycznego nadzorowania rozwoju. Osoby uczestniczące w procesie modelowo sekwencyjnym charakteryzują się daleko posuniętą specjalizacją. Problemy jednego działu mogą skutecznie sparaliżować cały proces, który jest dosyć czasochłonny. Odmienny model znany jako zintegrowany, nazywany jest niekiedy także równoległym. Zakłada on istnienie zespołu procesowego, który jednocześnie, wielopłaszczyznowo pracuje nad rozwojem produktu. Możliwe jest wyodrębnienie osoby, która czuwa nad całością procesu. Poziom skomplikowania wdrożenia tego modelu jest znacząco większy niż modelu sekwencyjnego, ale rekompensują to jego zalety - większa elastyczność, szybkość i odporność na wystąpie-nie niepożądanego ryzyka ${ }^{9}$. Wybór modelu dla procesu rozwoju produktu warunkuje liczba ośrodków zadaniowych z nim związanych oraz rodzaj problemów, jakie muszą zostać rozwiązane, aby uznać produkt za gotowy. Można tu wymienić takie obszary zadaniowe, jak: pomysł na produkt, jego ostateczne ukształtowanie, przypisanie mu marki, należyte opakowanie, dbałość o jego jakość, określenie klienta docelowego, fazę komercjalizacji i inne ${ }^{10}$.

Metody rozwoju produktów można określić jako swoistego rodzaju dobre praktyki, ułatwiające efektywne funkcjonowanie procesu. Przykładowo można wskazać jedno z narzędzi, jakim posługują się przedsiębiorstwa, by przełożyć potrzeby konsumentów na rysunki techniczne i schematy planistyczne inżynierów produkcji. Chodzi o dopasowanie funkcji jakości wywodzące się z Japonii (QFD - ang. Quality Function Deployment). Wyraża się ono poprzez macierz, która z lewej strony wymienia konkretne potrzeby klientów, a u góry wskazuje na możliwe fizyczne cechy rozwijanego produktu. Tabela tworząca część wspólną ww. części macierzy, zawiera miejsca, w których można wpisać „V”, gdy zachodzi zgodność potrzeby i możliwej cechy albo "X” w przypadku wykluczającym jednoczesne sprostanie danej potrzebie przy założeniu istnienia konkretnej cechy ${ }^{11}$. Innym przykładem metody wykorzystywanej w rozwoju produktów jest stosowanie tzw. Poka Yoke, czyli rozwiązań uniemożliwiających błędne zastosowanie urządzenia, które wychodzi naprzeciw oczekiwaniom klientów, chcących długo, bezpiecznie i prawidłowo korzystać z dóbr, zgodnie z ich społeczno-gospodarczym przeznaczeniem.

\footnotetext{
${ }^{9}$ Ibidem, s. 60-61.

${ }^{10}$ A. Rudzewicz, A. Strychalska-Rudzewicz, Strategie produktów innowacyjnych, Wydawnictwo Uniwersytetu Warmińsko-Mazurskiego w Olsztynie, Olsztyn 2013, s. 5-6.

${ }^{11}$ C. Bozarth, R.B. Handfield, Wprowadzenie do zarządzania operacjami i łańcuchem dostaw, Wydawnictwo Helion, Gliwice 2007, s. 219-221.
} 
Kontrola procesu jest jego niezbędną częścią, umożliwiającą powodzenie przedsięwzięć. Dostarcza ona witalnych informacji o procesie, gwarantuje jego przebieg zgodny $\mathrm{z}$ założeniami przedsiębiorstwa, w razie odstępstw od planu, umożliwia odpowiednią reakcję, $\mathrm{w}$ tym działania korekcyjne i korygujące, a także pozwala w pełni zrozumieć możliwości przedsiębiorstwa, ujawniając czynniki przewagi konkurencyjnej. Kontrola jest niezbędna na każdym etapie procesu rozwoju nowego produktu: poszukiwaniu pomysłów, ich selekcji, koncepcji produktu, analizy ekonomicznej, właściwego rozwoju produktu, testowania produktu oraz jego wprowadzenia ${ }^{12}$.

Ryzyko mające negatywny wpływ w przedmiotowej materii można określić i ocenić jako potencjalne straty przedsiębiorstwa, które mogą wystąpić z różnych powodów. Zarządzanie ryzykiem towarzyszy niemal każdemu rodzajowi aktywności podejmowanej w życiu, nie tylko przedsięwzięciom biznesowym. Nie inaczej jest w przypadku rozwoju nowego produktu. Konieczność wprowadzenia produktu do obrotu wymaga określenia, że nowy produkt nie jest niebezpieczny dla potencjalnego użytkownika oraz wyposażenia go w szczegółowe informacje dotyczące tego, co można, a czego nie można robić z danym produktem. Istnieją liczne metody umożliwiające identyfikację ryzyka, jakie niesie ze sobą rozwój produktu. Są to m.in. analiza założeń, burza mózgów, spis kontrolny, metoda delficka, rewizja dokumentów, diagramy, niezależne oszacowanie, wywiady, sieć triangulacyjna ${ }^{13}$. Nie sposób wymienić wszystkie potencjalne rodzaje ryzyka, zagrażające procesowi rozwoju produktu. Nie zwalnia to jednak z konieczności decydowania o tym, czy poszczególne z nich należy ignorować, transferować, ograniczać, czy może nawet akceptować.

Ostatnim obszarem tematycznym procesu rozwoju produktu, wymagającym omówienia w tej części rozdziału, jest kwestia dokonywania pomiarów zdolności przedsiębiorstwa w zakresie wdrażania i funkcjonowania procesu. Istnieje szereg wzorów i zestawień tabelarycznych do szczegółowego zestawienia statystycznego kondycji przedsiębiorstwa, a nawet całych łańcuchów dostaw. W tym rozdziale warto zwrócić szczególną uwagę na pomiar poziomu nowości produktu. Można go zdefiniować jako badanie zdolności odróżniania danego produktu względem przyjętego punktu odniesienia, którym może być skonkretyzowany inny produkt bądź całkowicie abstrakcyjny wzorzec. Najczęściej można się spotkać z dychotomicznym podziałem na produkty nowe i ulepszone. Pierwszy z nich istotnie różni się od produkowanych i funkcjonujących w obrocie towarów. Cecha nowości może być oczywiście względna, w zależności od rozpatrywanego terytorium (rynek lokalny, krajowy, globalny). Produkt ulepszony określa się jako zmodyfi-

${ }^{12}$ B. Siuta-Stolarska, M. Krzyżak, Zarządzanie produktem, Wyższa Szkoła Oficerska Wojsk Lądowych, Wrocław 2014, s. 62-65.

${ }^{13}$ I. Rutkowski, Metody identyfikacji i ograniczania ryzyka strategii rozwoju nowego produktu [w:] Zarzadzanie produktem - teoria, praktyka, perspektywy, red. J. Kall, B. Sojkin Wydawnictwo Akademii Ekonomicznej w Poznaniu, Poznań 2008, s. 209-213. 
kowana wersja dobra uprzednio funkcjonującego w obrocie, którego niektóre parametry uległy zmianie. W zależności od stopnia ingerencji przeprowadzane jest dalsze stopniowanie tej kategorii ${ }^{14}$.

Jak zostało zaprezentowane, rozwój produktu jest procesem złożonym i wymagającym wielopłaszczyznowego rozważenia. Dopiero holistyczne podejście do tego procesu może zapewnić współcześnie funkcjonującemu przedsiębiorstwu sukces na rynku. Nadszedł czas, by zidentyfikować i odzwierciedlić ww. elementy $\mathrm{w}$ aktualnym przykładzie.

\subsection{TRAMicus I SWING - SZTANDAROWE PRZYKEady ROZWOJU PRODUKTów PESY}

PESA to polski zakład produkcyjny, działający w branży elektromaszynowej, który powstał po restrukturyzacji Zakładów Naprawy Taboru Kolejowego Bydgoszcz. Tradycje przedsiębiorstwa sięgają połowy XIX wieku, jednak współczesna historia firmy datowana jest od końca lat 90 . XX wieku Wtedy zarząd przedsiębiorstwa podjął decyzję, by obok świadczenia usług naprawczych i modernizacyjnych istniejącego taboru szynowego, zaoferować klientom zupełnie nowe pojazdy własnej konstrukcji. Zdecydowano także o poszerzeniu profilu produkcji pojazdów szynowych, aby obok lokomotyw i taboru kolejowego rozpocząć montaż tramwajów. Obecnie szynowe pojazdy miejskiej komunikacji zbiorowej stanowią najważniejszą część produkcji zakładów PESA.

Pierwszym modelem tramwaju zbudowanym od podstaw przez PESĘ był Tramicus (Fotografia 1). W latach 2006-2008 wyprodukowano 33 szt. tego pojazdu, przy czym w zależności od miasta, do którego poszczególne modele miały trafić, tramwaje te produkowano $w$ jednym $\mathrm{z}$ trzech wariantó ${ }^{15}$. Typ $120 \mathrm{~N}$ oznacza pięcioczłonowy model tramwaju o standardowym rozstawie kół $1435 \mathrm{~mm} .63$ miejsca siedzące i szacowane 148 miejsc stojących wewnątrz pojazdu zapewniają optymalną przestrzeń dla pasażerów poruszających się w ramach wielkomiejskiego systemu komunikacji zbiorowej. ZTM Warszawa zdecydowało się na zakup 15 szt. pojaz-dów tego typu, które skierowano m.in. na linię nr 9. 121N jest trzyczłonowym tramwajem, przeznaczonym do eksploatacji na liniach tramwajowych o rozstawie szyn $1000 \mathrm{~mm}$. Maksymalna liczba przewożonych osób sięga ok. 120 pasażerów, co w ocenie ZKM Elbląg (które korzysta z 6 szt. tramwajów tego typu, obsługujących m.in. linię nr 3) jest wystarczające dla potrzeb tego przewoźnika. $122 \mathrm{~N}$ to wariant pięcioczłonowego tramwaju dedykowanego podobnie jak $121 \mathrm{~N}$ systemom komunikacji tramwajowej funkcjonującym w oparciu o rozstaw szyn $1000 \mathrm{~mm}$. Mogące pomieścić ponad 200 pasażerów pojazdy zostały dostarczone do MZK Bydgoszcz (w liczbie 2 szt. służą realizacji przewozów m.in. na linii nr 3)

\footnotetext{
${ }^{14}$ B. Siuta-Stolarska, M. Krzyżak, op. cit., s. 47-51.

${ }^{15} \mathrm{http}: / /$ www.pesa.pl/firma/wspolczesnosc/ [10.01.2016].
} 


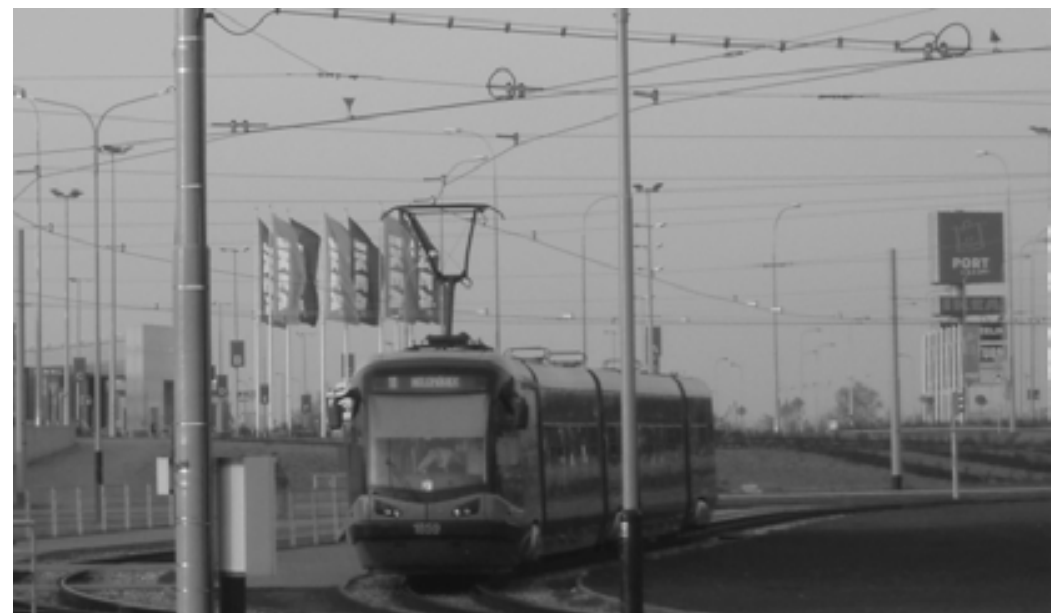

Fotografia 1. Tramicus $122 \mathrm{~N}$ w Łodzi na pętli tramwajowej Chocianowice-Ikea Źródło: fot. P. Mikołajczyk.

oraz do MPK Łódź (10 szt. tego pojazdu przeznaczono przede wszystkim na potrzeby linii nr 11, będącej częścią projektu Łódzki Tramwaj Regionalny). Istotną cechą wspólną wszystkich tramwajów typu Tramicus jest posiadanie jednoprzestrzennego, niskopodłogowego przedziału pasażerskiego dostosowanego do potrzeb osób niepełnosprawnych. Wszystkie tramwaje Tramicus są jednokierunkowe ${ }^{16}$. Kwestie estetyki pojazdów oraz szczegółowego wyposażenia są ściśle spersonalizowane pod kątem zamawiającego.

Bezpośrednim następcą Tramicusa jest PESA Swing (Fotografia 2). Od 2010 roku wyprodukowano ponad 300 pojazdów. Ponad połowa z nich została dostarczona do Warszawy w ramach dużego kontraktu na wymianę taboru eksploatowanego przez ZTM Warszawa. Umowę tę nazwano kontraktem stulecia ze względu na rekordową wartość zamówienia - 1,5 mld $\mathrm{PLN}^{17}$. Wygranie przetargu i dostawa Swingów do stolicy Polski była jednym z czynników, który doprowadził do pojawienia się tego modelu na torach innych polskich miast, a także do ekspansji na rynki zagraniczne. Na chwilę obecną można wyróżnić aż 14 wariantów bydgoskiego Swinga: $120 \mathrm{Na}, 120 \mathrm{NaDuo}, 120 \mathrm{NaC}, 120 \mathrm{NaG}, 120 \mathrm{NaS}$, 120NaS2, $120 \mathrm{Nb}, 121 \mathrm{NaK}, 121 \mathrm{NbT}, 122 \mathrm{NaSF}, 122 \mathrm{NbT}, 122 \mathrm{NaB}, 122 \mathrm{NaL}$ i będący w trakcie produkcji tramwaj dla Torunia nienoszący jeszcze własnego oznaczenia. Zasadnicze cechy wspólne dla tramwajów rodziny Swing nie zmieniły

\footnotetext{
${ }^{16}$ Komunikacja miejska w Łodzi 1898-2013, red. E. Raczyńska-Buława, Wyd. Instytut Naukowo Wydawniczy TTS i Spatium sp. z o.o., Łódź 2013, s. 48, 182.

${ }^{17}$ http://www.rbf.net.pl/wiecej,Kontrakt-stulecia-podpisany,448 [10.01.2016].
} 


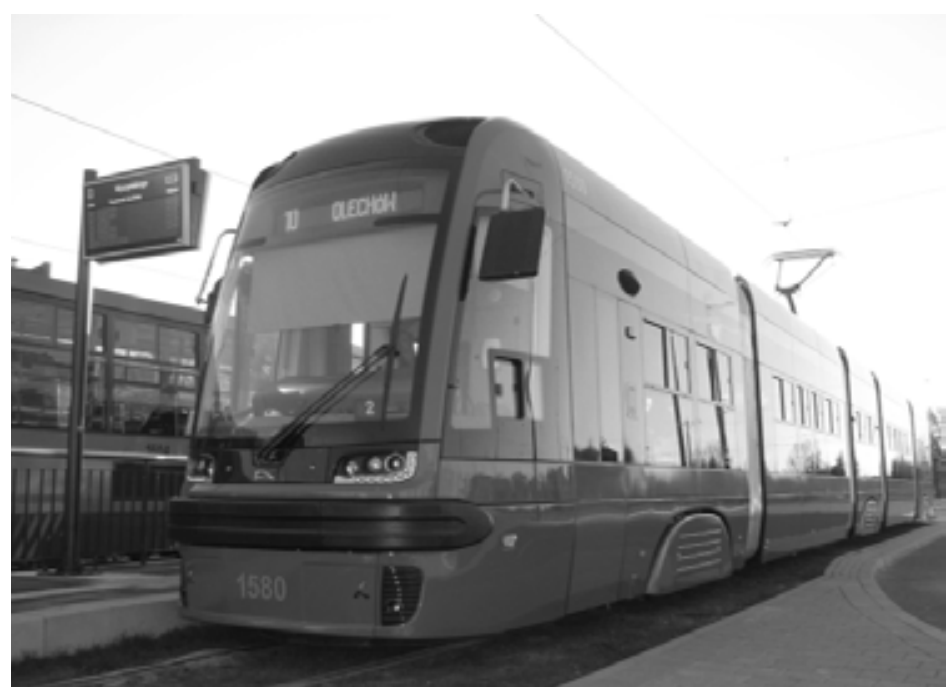

Fotografia 2. Swing $122 \mathrm{NaL}$ w Łodzi na pętli Wyszyńskiego Źródło: Ibidem.

się względem modelu Tramicus, wciąż są to wieloczłonowe, jednoprzestrzenne, niskopodłogowe przegubowce. Elementami różnicującymi poszczególne typy Swinga są natomiast: długość pojazdu (a co za tym idzie liczba członów), szerokość pudła, rozstaw szyn, na jakim pojazd ma być eksploatowany, liczba siedzeń i ich rozplanowanie, jedno- bądź dwukierunkowość oraz szczegółowe elementy wyposażenia takie, jak udogodnienia przestrzenne dla osób z ograniczonymi możliwościami ruchowymi oraz fabrycznie zainstalowana klimatyzacja, telewizja przemysłowa, automaty biletowy czy wi-fi.

\subsection{Kulisy dzialalności PESA Bydgoszcz S.A.}

Ewolucja od Tramicusa do Swinga pozwala na dostrzeżenie pewnych cech charakterystycznych dla produkcji PESY, dotyczących know-how przedsiębiorstwa, będących istotnymi elementami przewagi konkurencyjnej. Pierwszą, która jest najbardziej widoczna, jest poświęcenie olbrzymiej uwagi kwestiom związanym ze spełnieniem oczekiwań klientów poprzez indywidualizację produktu. Odbywa się ona nieustannie na wszystkich etapach procesu produkcji, począwszy od ustalenia jak duży pojazd jest potrzebny danemu przewoźnikowi, poprzez podjęcie decyzji o sposobie montażu siedzeń, a skończywszy na akcesoryjnych elementach wyposażenia w fazie końcowej montażu. Mnogość modeli Swinga jest wynikiem dopasowania do potrzeb systemów transportu zbiorowego poszczególnych miast. 
Takie podejście przywołuje skojarzenia z koncepcją Ansoffa, który olbrzymią wagę przywiązywał do dywersyfikacji. Szeroka gama oferowanych wariantów tramwajów PESY jest niczym innym jak tylko nieustannie rozwijaną dywersyfikacją produktową.

Wspominając o strategii rozwoju produktu, warto dostrzec zorientowanie przedsiębiorstwa do wewnątrz. PESA dąży do rozwoju poprzez naukę na własnych doświadczeniach. Zamiast szukać innowacyjnych rozwiązań u konkurencji, bydgoskie zakłady nieustannie powiększają własne zasoby, nie tylko materialne, ale i ludzkie. PESA dysponuje działem badań i rozwoju, w którym jest zatrudnionych ok. 250 specjalistów. Szacuje się, że jest to największy taki zespół w naszej części Europy, jeżeli chodzi o branżę produkcji środków transportu szynowego ${ }^{18}$. Utrzymanie takiej kadry jest motywowane chęcią daleko posuniętej analizy i weryfikacji rozwiązań stosowanych we własnych produktach. Pomiary jakości produktów wyrażają się nie tylko licznymi certyfikatami takimi, jak m.in. Q1 i IRIS 02. Eksperci PESY opracowują własne rozwiązania jakościowe i patentują innowacyjne rozwiązania, np. układy odzyskiwania energii elektrycznej z trakcji czy system przemieszczania pojazdu na pewną odległość w razie zaniku napięcia ${ }^{19}$. Dodatkowo, jako lider łańcucha dostaw, współpracując z licznymi podmiotami zewnętrznymi PESA stara się kontrolować stałe polepszanie jakości dostarczanych jej podzespołów.

Kadra kierownicza przedsiębiorstwa jest skłonna do podejmowania dużego ryzyka, jeżeli rozpoznaje możliwość intensywnego rozwoju. Tak było w przypadku realizacji umowy na dostarczenie 22 tramwajów Swing $122 \mathrm{NaL}$ do Łodzi. Data realizacji zamówienia dla MPK Łódź okazała się być temporalnie zbieżna $\mathrm{z}$ czasem zakończenia dostaw dla innych podmiotów. Dla Krakowa miało powstać 36 Twistów, dla Bydgoszczy 12 Swingów, na swoje tramwaje czekały też Warszawa i Toruń. Media ukuły w odniesieniu do PESY termin „klęska urodzaju”, wskazując niebezpieczeństwo związania się tak dużą liczbą zamówień jednocześnie ${ }^{20}$. Okazało się, że nie były to bezzasadne uwagi.

W połowie 2015 roku w firmie wykryto tzw. wąskie gardło. Zakład produkcyjny w Bydgoszczy okazał się nieprzygotowany do produkcji w rozmiarach odpowiadających zakontraktowanym pojazdom. Lider łańcucha dostaw dynamicznie zwiększył produkcję, zaskakując dostawców nagłym wzrostem zapotrzebowania na dostawy ich dóbr, co oznaczało trudności z przepływami, które spowolniły proces produkcyjny. Dodatkowymi czynnikami ryzyka w przedsiębiorstwie było naruszenie płynności finansowej, a także letnie upały, które spowodowały ogłoszenie 20. stopnia zasilania. Najtrudniejszą sytuacją, jaka mogła się wydarzyć, było jednak

\footnotetext{
${ }^{18} \mathrm{http}: / /$ www.pesa.pl/firma/?lang=pl_pl [10.01.2016].

${ }^{19} \mathrm{http}: / /$ www.pesa.pl/produkty/tramwaje/swing/ [10.01.2016].

${ }^{20} \mathrm{http}: / /$ www.polityka.pl/tygodnikpolityka/rynek/1644656,1,pesa-walczy-z-nadmiarem-kontraktow-jesli-sie-nie-uda-przepadnie-unijne-dofinansowanie.read [10.01.2016].
} 
przekroczenie terminów, związane z wysokimi karami umownymi za opóźnienie. Ostatecznie PESA wywiązała się ze zobowiązania względem Łodzi. Niepewność trwała jednak do 31 grudnia 2015 roku. Kluczowe dla powodzenia realizacji dostawy było zidentyfikowanie problemów. Ważnym elementem, który pozwolił spełnić świadczenie na czas, była szczerość wobec klientów. Pozwoliła ona wypracować nietypowe, lecz skuteczne porozumienie, na mocy którego MPK Łódź i MPK Kraków tymczasowo urlopowały swoich pracowników, by PESA mogła ich wynająć w celu szybszego zakończenia realizacji zamówień. Ponadto zza wschodniej granicy sprowadzono ok. 100 ukraińskich spawaczy. Pracę nad montażem pojazdów szynowych zorganizowano w taki sposób, że trwała ona niemal nieprzerwanie aż do ostatnich grudniowych dni ${ }^{21}$. Problem $z$ dostawcami w kwestii przepływów finansowych PESA rozwiązała w drodze negocjacji. Synergiczne podejście pozwoliło na względnie terminowe zakończenie prac.

\section{Podsumowanie}

Rozwój produktu stanowi złożony proces z pogranicza logistyki i marketingu, którego efektem są nowatorskie dobra oferowane na rynku. Przedsiębiorstwa, które potrafią skutecznie wdrożyć i korzystać $z$ tego procesu, mają większe szanse na osiągnięcie strategicznej przewagi w konkurowaniu $\mathrm{z}$ innymi podmiotami. PESA Bydgoszcz S.A., podążając za potrzebami użytkowników osiągnęła imponujący sukces na polu produkcji wysokoprzetworzonych pojazdów szynowych. Nie oznacza to jednak, że w pełni skorzystała z dorobku naukowego opisującego rozwój produktu. Gdyby tak było, być może przedsiębiorstwo uniknęłoby ciężkiej walki, którą toczyło w drugiej połowie 2015 roku o terminowe wywiązanie się z zakontraktowanych tramwajów. Wydaje się, że dobrą radą dla PESY, byłoby przeprojektowanie procesu produkcji w skali całego łańcucha dostaw na model bardziej zintegrowany. Być może, gdyby dostawcy od razu w momencie wygrania przez lidera przetargu wiedzieli, o ile w najbliższym czasie wzrośnie zapotrzebowanie na ich komponenty, zwiększona produkcja byłaby mniej narażona na przestoje spowodowane brakami podzespołów w hali montażowej. Warto korzystać z osiągnięć nauki, a jeszcze lepiej bezpośrednio wdrażać je do praktyki przemysłowej.

\section{Bibliografia}

Armstrong G., Kotler P., Marketing. Wprowadzenie, Wolters Kluwer, Warszawa 2015.

Bozarth C., Handfield R. B., Wprowadzenie do zarządzania operacjami i łańcuchem dostaw, Wydawnictwo Helion, Gliwice 2007.

Klincewicz K., Dyfuzja możliwości. Jak odnieść sukces w komercjalizacji nowych produktów i usług, Wydawnictwo Naukowe Wydziału Zarządzania Uniwersytetu Warszawskiego, Warszawa 2011.

${ }^{21}$ http://biznes.newsweek.pl/pesa-nie-zaplaci-kar-zdazyla-z-dostawa-pociagow-w-ostatniej-chwili -,artykuly,376502,1.html [10.01.2016]. 


\section{ROZWÓJ PRODUKTÓW POLSKIEGO PRZEMYSŁU ELEKTROMASZYNOWEGO NA PRZYKŁADZIE...}

Komunikacja miejska w Łodzi 1898-2013, red. E. Raczyńska-Buława, Wyd. Instytut Naukowo Wydawniczy TTS i Spatium sp. z o.o., Łódź 2013.

Rudzewicz A., Strychalska-Rudzewicz A., Strategie produktów innowacyjnych, Uniwersytet Warmińsko-Mazurski w Olsztynie, Olsztyn 2013.

Rutkowski I., Metody identyfikacji i ograniczania ryzyka strategii rozwoju nowego produktu [w:] red. J. Kall, B. Sojkin, Zarządzanie produktem - teoria, praktyka, perspektywy, Wydawnictwo Akademii Ekonomicznej w Poznaniu, Poznań 2008.

Rutkowski I., Rozwój nowego produktu. Metody i uwarunkowania, PWE, Warszawa 2007.

Siuta-Stolarska B., Krzyżak M., Zarządzanie produktem, Wyższa Szkoła Oficerska Wojsk Lądowych, Wrocław 2014.

Słownik terminologii logistycznej, red. T. Janiak, Instytut Logistyki i Magazynowania, Poznań 2006. www.mfiles.pl [07.01.2016].

www.newsweek.pl [10.01.2016].

www.nfosigw.gov.pl [30.03.2016].

www.pesa.pl [10.01.2016].

www.polityka.pl [10.01.2016].

www.rbf.net.pl [10.01.2016]. 

Dr Joanna Piorunowska-Kokoszko

Katedra Logistyki

Uniwersytet Łódzki

ul. Matejki 22/26, 90-237 Łódź

\section{Grupy zakupowe jako innowacja organizacyjna w działalności małych i średnich przedsiębiorstw w Polsce}

\section{WPROWADZENIE}

Niniejszy rozdział ma na celu wskazanie, iż innowacje stają się podstawą przetrwania dla przedsiębiorstw we współczesnym świecie. Tworzenie czy przyłączenie się do grup zakupowych jest dla małych i średnich przedsiębiorstw (MŚP) sposobem optymalizacji kosztów oraz podniesienia zdolności konkurowania na obecnym rynku zdominowanym przez korporacje zagraniczne i sieci usługowohandlowe. W rozdziale zaprezentowano koncepcję działania grupy zakupowej, jej wyniki oraz zaproponowano rozważenie włączenia grupy zakupowej do łańcucha dostaw jako formy innowacji organizacyjnej. W oparciu o zebrane dane wskazano, iż takie rozwiązanie pozwoli MSSP zwiększyć zyski z działalności, podnieść konkurencyjność i poprawić pozycję na rynku.

\subsection{INNOWACJE I ICH ZNACZENIE W DZIALALNOŚCI PRZEDSIĘBIORSTW}

We współczesnej gospodarce rozwój społeczno-gospodarczy determinowany jest przede wszystkim poziomem konkurencyjności, czyli dostosowaniem do obecnych potrzeb rynku, stosowanych technologii, rozwiązań organizacyjnych, wytwarzanych produktów czy usług. Konkurencja i konkurencyjność jako immanentne cechy współczesnego rozwoju wymuszają innowacje, które są twórczą odpowiedzią napojawiające się okazjei wyzwania rynku ${ }^{1}$.Innowacja, czyli wprowadzenienowych produktów, procesów lub sposobów postępowania ${ }^{2}$, tworzy dla siebie samej popyt już przez samo pojawienie się nowej potrzeby lub dążenie do zaspokojenia istniejącej w nowy sposób. Przez swoją nowoczesność staje się płaszczyzną konkurencji, a w krótkim czasie pozwala przedsiębiorstwu uzyskać przewagę konkurencyjną, co powoduje, że najczęściej poszukuje się jej źródeł w różnych obszarach funkcjonowania przedsiębiorstwa, np. marketingu (dobór nowoczesnych, odpowiednio dobranych narzędzi umożliwiających komercjalizowanie nowych produktów, kształtowanie kanałów dystrybucji i relacji z klientami), w produkcji (wykorzystywanie

\footnotetext{
${ }^{1}$ P. Drucker, Innowacja i przedsiębiorczość. Praktyka i zasady, PWE, Warszawa 1992, s. 37.

2 J. Penc, Innowacje i zmiany w firmie, AW Placet, Warszawa 1999, s. 141-143.
} 
metod wspomagających uruchamianie nowej produkcji, sterowanie produkcją), w obszarze logistyki (kreowanie systemów logistycznej obsługi klienta, implementacja nowoczesnych systemów informatycznych usprawniających współprace i komunikowanie się z klientami i dostawcami), w obszarze badań i rozwoju czy zarządzania kadrami ${ }^{3}$. Z uwagi na zakres innowacji można je sklasyfikować jako innowacje produktowe, procesowe i organizacyjne. Badania przedstawione przez M. Pieńkowską ${ }^{4}$ wskazują, że ok. $21 \%$ ogółu przedsiębiorstw stanowią przedsiębiorstwa, które wdrożyły innowacje produktowe lub procesowe. Natomiast ok. $20 \%$ ogółu przedsiębiorstw to organizacje, które dokonały implementacji innowacji organizacyjnych lub marketingowych. Współcześnie zmienia się jednak podejście do innowacji, gdyż globalna gospodarka staje się gospodarką sieciową, a innowacje są coraz częściej realizowane w złożonych łańcuchach i sieciach współpracujących ze sobą przedsiębiorstw. W klasycznym ujęciu innowacje opierały się na przekonaniu, że podstawą działalności innowacyjnej przedsiębiorstwa jest własny dział badawczo-rozwojowy i jego działalność. Tymczasem obecnie budowane są sieci przedsiębiorstw, których celem jest efektywny transfer i rozwój wiedzy, umiejętności partnerów oraz skuteczna reakcja na zmieniające się uwarunkowania realizacji procesów innowacji w gospodarce. Innowacyjność wymaga zatem od przedsiębiorstw zaangażowania odpowiednich nakładów finansowych, kadry, wiedzy, umiejętności oraz właściwej kultury wspierającej kreatywność i otwartość na nowe pomysły. Przez swój nowoczesny charakter każda innowacja wiąże się z ogromną niepewnością, co do jej skutków. Niepewność ta powiększana jest przez brak wiedzy na temat wprowadzanych unowocześnień czy znaczących zmian w schematach działania przedsiębiorstwa.

\subsection{INNOWACYJNOŚć MAEYCH I ŚREDNiCH PRZEDSięBIORSTW W Polsce}

Innowacyjność nie dotyczy tylko dużych firm. Małe i średnie przedsiębiorstwa (MŚP $)^{5}$ stanowią według P. Druckera „sól gospodarki rynkowej”, co oznacza,

\footnotetext{
${ }^{3}$ A.I. Szymańska, Innowacyjność produktowa przedsiębiorstw produkcyjnych a preferencje konsumentów [w:] Wpływ innowacyjności na rozwój przedsiębiorstw, red. Z. Zioło, T. Rachwał, Prace Komisji Geografii Przemysłu nr 19, Kraków 2012.

${ }^{4}$ M. Pieńkowska, Innowacyjność przedsiębiorstw przemysłowych, [w:] Raport o innowacyjności gospodarki Polski w 2009 roku, red. T. Baczko, PAN, Warszawa 2010, s. 80.

${ }^{5}$ Dla potrzeb niniejszego artykułu przyjęto definicję MŚP Komisji Europejskiej, według której przedsiębiorstwo średnie definiuje się jako przedsiębiorstwo zatrudniające mniej niż 250 pracowników, którego roczny obrót roczny nie przekracza $50 \mathrm{mln}$ EUR oraz/lub całkowity bilans roczny nie przekracza 43 mln EUR, małe definiuje się jako przedsiębiorstwo zatrudniające mniej niż 50 pracowników, którego roczny obrót oraz/lub całkowity bilans roczny nie przekracza $10 \mathrm{mln}$ EUR. Mikroprzedsiębiorstwo definiuje się jako przedsiębiorstwo zatrudniające mniej niż 10 pracowników, którego roczny obrót oraz/lub całkowity bilans roczny nie przekracza 2 mln EUR. - Rozporządzenie Komisji Europejskiej nr 651/2014 z dnia 17 czerwca 2014 roku http://ec.europa.eu/enterprise/ policies/sme/files/sme_definition/sme_user_guide_pl.pdf [07.04.2015].
} 
że ich siła rynkowa ma wyjątkowy potencjał ${ }^{6}$. W przedsiębiorstwach tych w większym stopniu innowacje opierają się na nieformalnych, a więc trudno mierzalnych, działaniach badawczo-rozwojowych i rzadziej korzystają z zewnętrznych źródeł wiedzy (usług doradczych oraz licencji) niż ich większe odpowiedniki. Zjawisko to odzwierciedla mniejszą zdolność MŚP do absorpcji wiedzy zewnętrznej. Tym niemniej przedsiębiorstwa $\mathrm{z}$ tego sektora wprowadzają innowacje i wykorzystują je jako element zdobywania oraz utrzymywania swojej pozycji na rynku ${ }^{7}$. Raport Instytutu Badań nad Gospodarką Rynkową Lewiatan podaje, iż MŚP są jednak mniej efektywne niż firmy duże: jedna osoba pracująca w sektorze dużych przedsiębiorstw wytwarza ponad dwa razy więcej wartości dodanej niż jedna osoba w sektorze firm MŚP ${ }^{8}$. Im mniejsza firma, tym ta relacja jest mniej korzystna. Charakteryzują się one też znacznie słabszą kondycją ekonomiczno-finansową w porównaniu do dużych przedsiębiorstw. Świadczy o tym np. wartość nakładów inwestycyjnych przypadających na jednego zatrudnionego. Ze względu na ograniczenia finansowe nie prowadzą one badań naukowych na szeroką skalę. Ich działalność innowacyjna związana jest $\mathrm{w}$ większym stopniu $\mathrm{z}$ aktualnymi potrzebami rynku, potencjalnych klientów i użytkowników. Organizacje te również silniej niż większe przedsiębiorstwa odczuwają bariery związane z prowadzeniem działalności gospodarczej. Dlatego też zwiększenie stopnia innowacyjności małych i średnich przedsiębiorstw stanowi konieczny warunek ich konkurencyjności i utrzymania dobrej pozycji rynkowej ${ }^{9}$. Potwierdzają tę tendencję badania przeprowadzone w ramach Pomorskiego Obserwatorium Gospodarczego, które wskazują, że MŚP deklarują duże zainteresowanie wdrażaniem innowacji (83\% ankietowanych przedsiębiorstw - wykres 1). Niestety nieco gorzej wypada skala tych innowacji, które w większości przypadków (ponad 50\%) były nowością jedynie w skali firmy, a nie rynku lokalnego czy krajowego (wykres 2). Innowatorem w skali rynku lokalnego była zaledwie co czwarta badana firma, a w skali krajowej - niespełna co piąta. Warto również zauważyć, że były to jedynie deklaracje, więc w rzeczywistości odsetek firm wprowadzających innowacje w skali lokalnej czy krajowej mógł być jeszcze mniejszy ${ }^{10}$.

Wdrażanie innowacji w MŚP nie jest łatwe z wielu powodów, główne bariery to: - ograniczone zasoby (m.in. finansowe),

- niski poziom profesjonalizmu w zarządzaniu innowacjami,

- brak zorientowania strategicznego,

${ }^{6}$ P. Drucker, Myśli przewodnie Druckera, MT Biznes, Warszawa 2002, s. 475.

${ }^{7}$ M. Zięba, P. Oster, Innowacyjność w małych i średnich przedsiębiorstwach, „E-mentor” nr 3 (40), 2011, http://www.e-mentor.edu.pl/artykul/index/numer/40/id/839 [20.04.2016].

${ }^{8}$ B. Wyżnikiewicz, Polskie MŚP na drodze ku nowoczesności, Instytut Badań nad Gospodarką Rynkową, 2013, s. 12.

${ }_{9}$ A. Stabryła, T. Małkus, Strategie rozwoju organizacji, Encyklopedia Zarządzania, Kraków 2012, s. 11.

${ }^{10}$ B. Wyżnikiewicz, op. cit. 


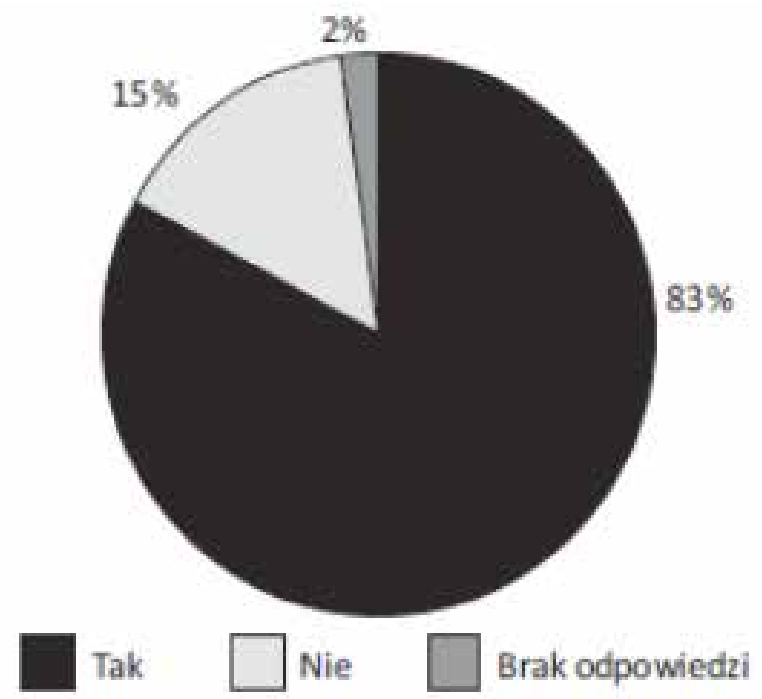

Wykres 1. Zainteresowanie wdrażaniem innowacji wśród pomorskich MŚP ( $\mathrm{n}=982)$

Źródło: P. Dominiak, J. Wasilczuk, N. Daszkiewicz, K. Zięba, A. Sobiechowska-Ziegert, Raport 2010 - Sektor Małych i Średnich Przedsiębiorstw na Pomorzu w warunkach pogorszenia koniunktury, Raport z badania MŚP w ramach Pomorskiego Obserwatorium Gospodarczego III, Agencja Rozwoju Pomorza, Szczecin 2010.

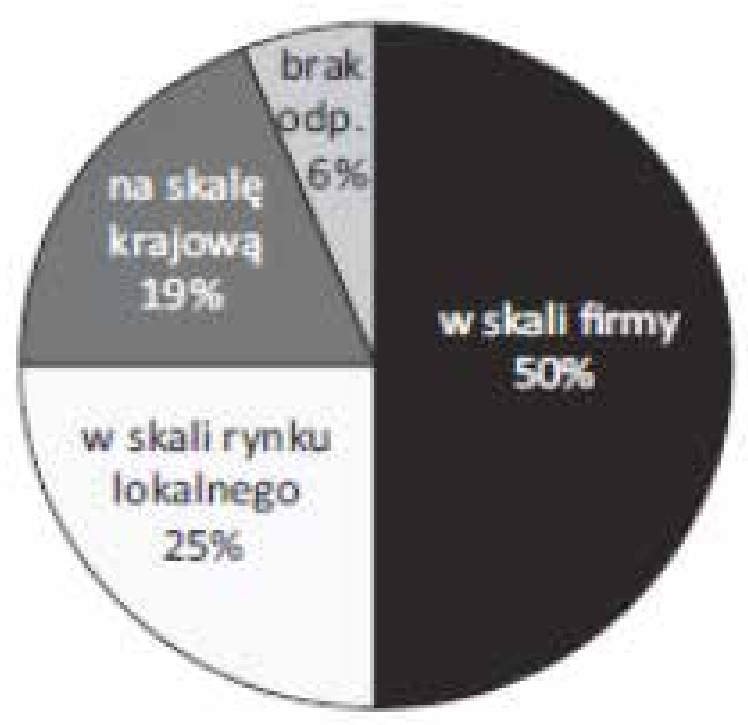

Wykres 2. Deklaratywne nowatorstwo wprowadzanej innowacji $(\mathrm{n}=814)$

Źródło: Ibidem. 
- brak umiejętności opracowania planu wdrożenia innowacji ze względu na nadmiar codziennych obowiązków przy ograniczonych zasobach ludzkich,

- brak kompetencji w zakresie innowacji w swoich strukturach,

- zależność od pracy poszczególnych pracowników ${ }^{11}$.

Ogólnie rzecz ujmując, problemy z wdrażaniem innowacji w MŚP wynikają często $\mathrm{z}$ faktu posiadania ograniczonych zasobów, tych materialnych i niematerialnych. Poszukiwanie oszczędności krępuje często innowacyjność tych przedsiębiorstw w różny sposób i w różnych obszarach. Jednym z takich obszarów są koszty działalności. Firmy poszukują oszczędności w minimalizacji wydatków. Najatrakcyjniejszą drogą obniżania kosztów firmy jest poszukiwanie oszczędności w zakupach, gdyż jest to zwykle największa lub jedna $z$ dwóch największych grup wydatków, więc ich redukcja o niewielki procent przynosi zauważalne efekty finansowe. Duże firmy wykorzystują w tym celu sourcing strategiczny. Małe natomiast poszukują rozwiązań mogących ich wspomóc w uzyskaniu zdolności konkurowania $\mathrm{z}$ dużymi podmiotami. Innowacyjnym rozwiązaniem w obu tych przypadkach są grupy zakupowe. Celem ich działalności jest wykorzystanie efektu skali w negocjowaniu cen zakupu np. danych surowców, paliwa czy energii. Uczestnictwo w grupach zakupowych pozwala wzmocnić pozycję negocjacyjną wobec dostawców i dzięki temu uzyskać korzystniejsze warunki współpracy, a w konsekwencji obniżyć poziom kosztów firmy. W polskiej gospodarce grupy zakupowe są nowym rozwiązaniem, stanowiącym jedną z możliwych form kooperacji przedsiębiorstw. Pojawienie się tej nowej struktury wywołuje jednak w firmie zmianę, często znaczącą w procesach przedsiębiorstwa i sposobie zarządzania. Ta innowacja korzystna w wymiarze finansowym spotyka się z barierą po stronie decydentów MŚP wynikającą z ich zachowawczych postaw. Podjęcie decyzji utrudnia przedsiębiorcom też brak informacji czy edukacji w zakresie działania grup zakupowych i ograniczone doświadczenia polskie w zarządzaniu takimi strukturami.

\subsection{GRUPY ZAKUPOWE JAKO INNOWACYJNE ROZWIĄZANIE DLA MAEYCH I ŚREDNICH PRZEDSIĘBIORSTW}

Rozwój grup zakupowych porównywany jest do tzw. ekonomii dzielenia się (ang. sharing economy) ${ }^{12}$. Idea ta przenosi się na działania wspólne firm i ich zrze-

\footnotetext{
${ }^{11}$ E. Kirner, O. Som, C. Dreher, V. Wiesenmaier, Innovation in KMU - Der ganzheitliche Innovationsansatz und die Bedeutung der Innovationsroutinen für den Innovationsprozess, Fraunhofer Institut System- und Innovationsforschung, 2006, http://isi.fraunhofer.de/isi/publ/download/isi06b18/ InnoKMU-Thesenpapier.pdf?pathAlias=/publ/downloads/isi06b18/InnoKMU-Thesenpapier.pdf [20.04.2016].

${ }^{12}$ Sharing economy to nowy trend w gospodarce, polegający na bezpośredniej wymianie dóbr i usług między konsumentami, którzy komunikują się przez specjalne serwisy internetowe. Tendencja ta została zaczerpnięta z Zachodu. Społeczeństwo amerykańskie, zmęczone kryzysem i ciągłym dążeniem do posiadania, dąży do implementacji idei współdzielenia: http://www.suwalki24.pl/mobile/article/1,_polska_wraca_do_komunizmu_ekonomia_sharing_w_natarciu [19.11.2015].
} 
szania się - taką aktywność określa się w literaturze jako „sharing zakupów”13. Zgodnie $\mathrm{z}$ tą genezą, grupa zakupowa (ang. group purchasing organization - GPO) to związek firm dokonujących skonsolidowanego zakupu za pośrednictwem wspólnego podmiotu. Funkcjonowanie grupy oparte jest na mechanizmie uzyskania lepszych warunków dostaw przy większym wolumenie zakupów (efekt skali) i większego nacisku na dostawców, co prowadzi do zmniejszenia kosztów transakcji. Kooperacja ta pozwala zachować siłę konkurencyjną dużego nabywcy przy zachowaniu koncentracji na kluczowych kompetencjach i dążeniu do obniżania kosztów transakcji małego i średniego podmiotu ${ }^{14}$.

Grupy zakupowe reprezentują interesy setki a czasami nawet tysięcy małych i średnich przedsiębiorstw i mogą obsługiwać:

- rynek wertykalny: grupy obsługujące spółki w określonym przemyśle albo segmencie rynku; tego rodzaju grupy są zazwyczaj zrzeszeniem branżowych producentów;

- rynek horyzontalny: w tym przypadku grupa zakupowa pracuje dla spółek wszystkich sektorów i segmentów rynku. Dobrym przykładem jest grupa kupująca od największego, kluczowego dostawcy, pozwalająca, aby jej członkowie mogli uzyskiwać produkty i usługi ze spółek partnera przy znacznych rabatach.

Najpowszechniej wykorzystywaną formą współpracy grup zakupowych w sektorze MŚP jest pozioma kooperacja ${ }^{15}$. Firmy przyłączają się bowiem do strategicznego aliansu, by zyskać pozycję przetargową wobec dostawcy, a MŚP tworząc więzi kooperacyjne w ramach łańcucha dostaw, wpływają również, na podniesienie wartości tego łańcucha ${ }^{16}$.

Grupy zakupowe współpracują z MŚP na różnych zasadach, mogą wymagać, by członkowie płacili opłaty za uczestnictwo, inne finansują się z prowizji od dostawców produktów i usług, a inni pobierają opłaty zarówno od dostawców, jak i członków grupy ${ }^{17}$.

Pierwsze grupy zakupowe pojawily się w USA w 1950 roku, gdzie obecnie są bardzo powszechne, a rynek zakupów uznaje się za dojrzały. Europa posiada grupy zakupowe już od XII wieku ${ }^{18}$. Obecnie najbardziej zaawansowanym krajem we wdrażaniu zakupów wspólnych jest Francja. W Wielkiej Brytanii grupy zakupowe działają głównie w sektorze energii elektrycznej np. Utilities Procure-

\footnotetext{
${ }^{13}$ P. Aigrain, Dzielenie się. Kultura i gospodarka epoki Internetu, Fundacja Nowoczesna Polska, Warszawa 2012, s. 17.

${ }^{14}$ E. M. Wrońska, Teoria kosztów transakcyjnych a grupy zakupowe, „Annales Universitatis Mariae Curie-Skłodowska", Lublin-Polonia, VOL. XLVI, 1, 2012, s. 142.

${ }^{15}$ www.AllBusiness.com [02.05.2015].

${ }^{16} \mathrm{H}$. Ghaderi, Z. Leman, Horizontal collaboration in purchasing: A successful case from small and medium enterprises (SMEs), „African Journal of Business Management”, Vol. 7(10), s. 752.

17 D. Sadler, How Group Purchasing Can Mean Big Savings for Small Businesses, www.allbusiness.com/how-group-purchasing-can-mean-big-savings-for-small-businesses-15037283-1.html [12.12.2015].

${ }^{18}$ M. Siedzieniewski, Jak zaryzykować i pociagnąć resztę, „Miesięcznik Dealer”, 20 lipca 2011, s. 38-40.
} 
ment Group. W Azji rynek grup zakupowych rozwinął się głównie w obszarze wysokich technologii i dotyczył zakupów podzespołów przez największych azjatyckich producentów sprzętu. Wymienić w tym miejscu można grupę FujiFilm, Hitachi czy Asia Pacific Utilities Group ${ }^{19}$. W polskim biznesie idea integrowania wybranych potrzeb zakupowych dopiero się rozwija i jest niewątpliwie dużą szansą dla MŚP. Głównym celem jest uzyskanie co najmniej porównywalnej siły zakupowej do sektora korporacji. Aby to było możliwe, konieczna jest silna integracja i współpraca przedsiębiorców reprezentujących różne branże. Mniejsze przedsiębiorstwa w Polsce coraz częściej rozpatrują przyłączenie się do grup zakupowych, ponieważ też chciałyby korzystać ze wspólnych zakupów i na tym oszczędzać. Nie jest to jednak takie proste. Przedsięwzięcie to wymaga bowiem porozumienia między menedżerami, ustalenia wspólnych warunków i szybkiej wymiany informacji. To wszystko powoduje, że prowadzenie wspólnych zakupów przez rozdrobnione małe firmy jest trudne do zorganizowania a następnie koordynowania. Dodatkowo indywidualni przedsiębiorcy nie do końca są świadomi, że nie mają takiej siły negocjacyjnej jak duże korporacje i stąd też nie poszukują rozwiązań skierowanych na jej zbudowanie. Przedsiębiorcy przeważnie nie mają czasu, często wiedzy i umiejętności, by skutecznie negocjować takie usługi, jak abonamenty telefoniczne, księgowość, ubezpieczenia, prąd, itp. Porównuje się ofertę 2-3 głównych graczy na rynku i wybiera się najlepszą z dostępnych ofert, uznając to za koniec możliwości negocjacyjnych. Decyzje zapadają często pod wpływem emocji. Wydatki te w skali roku są jednak poważną częścią budżetu małych firm. Każda złotówka zaoszczędzona przez przedsiębiorcę podwyższa jego konkurencyjność na rynku. Może on dzięki oszczędnościom świadczyć tańsze i lepsze usługi, więcej na tym zarabiając ${ }^{20}$. Dodatkowo niewielka popularność grup zakupowych wynikająca $\mathrm{z}$ braku dostępności informacji o ich działalności powoduje ograniczoną świadomość ich istnienia wśród kadry zarządzającej MŚP, co w konsekwencji wpływa na ograniczoną ilość i zakres działalności grup zakupowych. Pomimo wskazanej luki informacyjnej, grupy zakupowe zaczyna tworzyć Związek Przedsiębiorców i Pracodawców, Batna Group S.A., Lewiatan czy Polskie Składy Budowlane. Grupy te podzielone są na dwa rodzaje: ogólnopolskie i regionalne. Pierwsze pozwalają przystępować do siebie firmom z całego kraju i dają szansę na uzyskanie rabatów sięgających kilkunastu procent. Drugie są natomiast nastawione na współpracę z handlowcami, wyłącznie z wybranych regionów i tam też można liczyć na mniejsze korzyści - rzędu 5-8\%. Wśród tych grup wymienić można Grupę Polskich Sklepów PASSA współpracującą z 250 dostawcami, producentami i hurtowniami, Stowarzyszenie Kupców Polskich Przyjazny Sklep czy Polską Grupę Zakupową Kupiec ze 140 dostawcami $^{21}$. Popularne staje się

\footnotetext{
${ }^{19}$ www.apug.com [11.11.2015].

${ }^{20}$ www. v123235.home.net.pl [23.04.2015].

${ }^{21}$ www.forsal.pl [20.04.2015].
} 
tworzenie grup zakupowych przez jednostki samorządowe, jak np. Łódzka Grupa Zakupowa, zrzeszająca ponad 5000 podmiotów, która w 2014 roku zaoszczędziła $8 \mathrm{mln}$ PLN na zakupach energii ${ }^{22}$. Dostrzega się, że biznes outsourcingowy, którego odmianą są właśnie grupy zakupowe, w Polsce jest obecnie najszybciej rozwijającą się gałęzią przemysłu. Pracuje tam już ponad 100 tys. osób, a jeszcze 8 lat temu w ogóle jej nie było. Jest to wynikiem oddziaływania kryzysu na poszukiwanie oszczędności oraz wzmacnianie swojej pozycji na rynku zdominowanym przez duże podmioty zagraniczne i dyskonty.

Przystąpienie do grupy zakupowej przez MŚP ma jednak swoje wady i zalety. Wśród korzyści niewątpliwie wymienić można zachowanie niezależności prowadzonego biznesu, dostęp do nowych dostawców towarów i usług dzięki kontaktom grupy, możliwość rozszerzenia dotychczasowej oferty, obniżenie cen kupowanych towarów i usług od kilku do kilkunastu procent, a tym samym poprawę rentowności firmy, minimalizację ryzyka dostaw przez to, że współpraca odbywa się ze sprawdzonymi dystrybutorami, poprawę konkurencyjności i uzyskanie przewagi na tle niezależnie działających firm tej samej branży oraz sieci, oszczędność czasu czy dostęp do fachowców i szkoleń z zakresu sprzedaży i prowadzenia działalności gospodarczej. Dodatkowo skumulowana siła negocjacyjna pozwala osiągnąć efekt w postaci warunków lepszego zakupu niż w przypadku pojedynczego klienta. Efekt ten dotyczy nie tylko niższych cen zakupu, ale również lepszych warunków obsługi np. serwisu posprzedażoweggo czy standaryzacji i unifikacji asortymentu stosowanego w różnych placówkach, które z kolei mają wpływ na rzetelność dostaw. Poza wymiernymi ekonomicznymi warunkami zakupów, członkowie grupy zakupowej mogą liczyć także na szereg innych korzyści, do których zaliczyć można m. in. transfer wiedzy oraz innowacyjność ${ }^{23}$.

Wady przystąpienia do grupy zakupowej związane są z ograniczonym wyborem. Grup zakupowych jest w Polsce stosunkowo mało i obecnie rozpoczynają swoją działalność, co z uwagi na innowacyjny charakter rozwiązania ogranicza zaufanie potencjalnych członków do wyników i profesjonalizmu. Dodatkowo obawy powiększa konieczność podpisania umowy o współpracy, która jest najczęściej zawierana na czas nieokreślony, z trzymiesięcznym okresem wypowiedzenia, powodując znaczące uzależnienie się od grupy i często w dłuższym okresie czasu może prowadzić do utraty kompetencji firmy w zakupach. Specjalizacja oraz budowanie relacji z dostawcami przez poszczególne grupy zakupowe powoduje również, iż coraz więcej grup wymaga, by duża część asortymentu pochodziła od wskazanych przez nie dostawców i chcą mieć wpływ na rodzaj oferowanego przez firmę asortymentu. Grupy zakupowe z uwagi na sprawność działania nie przyjmują wszystkich

\footnotetext{
${ }^{22}$ www.dzienniklodzki.pl [20.12.2015].

${ }^{23}$ P. Bartkowiak, J. Domański, Szpitalne Grupy Zakupowe w kształtowaniu łańcucha wartości na rynku usług szpitalnych [w]: A. Marjański (red.) Przedsiębiorczy Menedżer Przedsiębiorczej Organizacji, Nowoczesne tendencje $w$ nauce oraz $w$ praktyce organizacji i zarządzania, „Przedsiębiorczość i Zarządzanie", tom XIV, zeszyt 3, Łódź 2013, s. 15.
} 
firm. Konieczność utrzymywania reżimu organizacyjnego i płatniczego powoduje, iż do grupy zakupowej nie są przyjmowane wszystkie MŚP, a jedynie te, które spełnią zdefiniowane przez grupę wymagania.

Rozwój grup zakupowych jest kuszący również z uwagi na odnotowywane przez nie wyniki tj. zmniejszenie kosztów od 8 do ponad 30\%. Badania naukowe wykazały też, że grupy zakupowe wynegocjowały średnio większy rabat dzięki kooperacji u dotychczasowych dostawców o ok. 5\%, co doprowadziło do obniżenia cen i uzyskania wyższych marż handlowych ${ }^{24}$. T. Hendricks potwierdza, że działalność grupy pozwoliła osiągnąć oszczędności na poziomie ok. 13,4\%, które dały średnio roczne oszczędności ok. 2,3 mln dla każdego członka ${ }^{25}$, a S. Khalid wskazuje, iż $21 \%$ z 1000 firm tworzących konsorcja zakupowe, średnio zaoszczędziło $10 \%$ dzięki działaniom grup zakupowych ${ }^{26}$. Zachęcające do udziału w grupach zakupowych są wyniki badań przeprowadzonych w Polsce przez firmę Audytel we współpracy ze Związkiem Powiatów Polskich oraz Związkiem Miast Polskich w maju 2014 roku. Potwierdzają one, iż powiaty i gminy nabywające energię elektryczną poprzez grupy zakupowe płacą średnio o 15,4\% taniej niż jednostki samorządowe kupujące energię samodzielnie ${ }^{27}$. Pierwszy nabór do Grupy Zakupowej Związku Przedsiębiorców i Pracodawców umożliwił wynegocjowanie $35 \%$ rabatu na prąd dla kilkunastu zrzeszonych firm. Przekładając to na jedną firmę płacącą 500 PLN miesięcznie za prąd, włączenie się do grupy zakupowej doprowadzi do zredukowania tego rachunku do ok. 350 PLN, co oznacza roczne oszczędności rzędu 2 tys. PLN ${ }^{28}$. Badania Instytutu Logistyki i Magazynowania (ILIM) dotyczące przemysłu spożywczego (Klaster spożywczy południowej Wielkopolski), wskazują na możliwość zaoszczędzenia 7\% na kosztach energii już przy 8 firmach reprezentowanych w negocjacjach ${ }^{29}$. Należy również nadmienić, iż dokonane oszczędności nie są jedyną korzyścią. G. Zimon zaznacza, że zagrożeniem nie jest zachwianie źródeł finansowania, gdyż działalność grupy nie powoduje wzrostu zadłużenia, a przedsiębiorstwa uzyskują dłuższe terminy płatności. G. Zimon wykazał, iż średni wskaźnik globalnego zadłużenia firmy w jednostkach zrzeszonych w grupach zakupowych wyniósł średnio 0,56 , co potwierdza, iż funkcjonowanie tych podmiotów jest bezpieczne. Dodatkowo analiza wykazała, iż $90 \%$ zobowiązań to zobowiązania krótkoterminowe wynikające właśnie z wynegocjowanych warunków płatności przez grupę zakupową. Stąd prognozy ekonomistów

\footnotetext{
${ }^{24}$ H. Ghaderi, Z. Leman, op. cit., s. 750-753.

${ }^{25}$ K. Gray, Consortia, Buying Groups and Trends in Demand Aggregation, VP Corporate Strategy, 2006.

${ }^{26}$ S. Khalid, The True Value of GPOs and Purchasing Consortiums, „Instasupply”, No. 10, 2014.

${ }^{27}$ G. Bernatek, E. Konarzewski, Efektywność zakupu energii elektrycznej w Jednostkach Samorzadu Terytorialnego, Raport z badania Audytel przeprowadzonego we współpracy ze Związkiem Powiatów Polskich, czerwiec, 2013.

${ }^{28}$ www.forbes.pl [24.11.2015].

${ }^{29}$ www.klaster.kalisz.pl [30.11.2015].
} 
wskazujące, iż grupy zakupowe będą dynamicznie rozwijać się w Polsce właśnie $\mathrm{z}$ uwagi na wskazane bezpośrednie profity dla MŚP, które przełożą się na ich efektywność. Obecny kryzys dodatkowo zwiększa taktyczne postrzeganie zakupów w przedsiębiorstwach. Firmy oczekują szybkich działań w sferze optymalizacji zakupów, a strategiczne działania odkładane są „na później” ze względu na potrzebę uzyskania jak najszybszych efektów. Powyższe badania wykazują, iż pomimo trudności w koordynacji prac grupy zakupowej, konieczności dostosowania się MŚP do zasad działania takiej grupy, uzyskane wyniki pozwalają obniżyć koszty, a tym samym podnieść marże handlowe, zachęcając tym samym menedżerów do objęcia działaniami grup innych obszarów zakupów. Potencjalnie perspektywy rozwoju tego rodzaju działalności są duże, a na potrzebę ich istnienia wskazuje choćby powodzenie zakupów grupowych w segmencie konsumpcyjnym, potwierdzoną sukcesem Groupona. Implementacja tego rodzaju działalności w obszarach biznesowych wydaje się być zatem naturalną konsekwencją poszukiwań usprawnień organizacyjnych w łańcuchach dostaw MŚP.

\section{Podsumowanie}

MŚP same walczą o przetrwanie i rozwój, często nie dysponując odpowiednimi zasobami, co powoduje, że zdobycie porównywalnej siły zakupowej do sektora korporacji jest trudne. Innowacje są drogą do osiągnięcia tych zamierzeń. Stąd pojawiają się $\mathrm{w}$ Polsce pierwsze formy kooperacji, a ich przejawem jest wzrastająca popularność sieci franchisingowych ${ }^{30}$ pozwalających właśnie tę siłę osiągnąć. Współpraca ta niszczy jednak niezależność przedsiębiorstwa. MŚP poszukują rozwiązań, które pozwolą doświadczenia dużych firm implementować do sektora MŚP i zmienią filozofię podejścia do gospodarki. Naturalnym dążeniem jest zatem organizowanie się m.in. w grupach zakupowych, będące jednym ze sposobów na przezwyciężenie rozproszenia polskich przedsiębiorców. Bez dobrej organizacji samych przedsiębiorców podjęcie działań nie będzie możliwe. Doświadczenia polskie w zakresie tworzenia i zarządzania takimi grupami nie są duże. Dodatkowo ograniczeniem do przystąpienia do grup są sami przedsiębiorcy i ich zachowawcze postawy. Podjęcie decyzji utrudnia przedsiębiorcom też brak informacji czy edukacji w zakresie działania grup zakupowych. Kuszące są jednak oszczędności kosztów. Stąd w oparciu o pozytywne wyniki działalności konsorcjów zakupowych można spodziewać się jednak ich rozwoju. Redukcja kosztów zakupowych ma bowiem na ogół dużo mocniejsze przełożenie na poprawę wyniku operacyjnego niż podobnej skali działania ukierunkowane na wzrost sprzedaży. Rozwiązanie

${ }^{30}$ Zgodnie z Raportem o franczyzie w Polsce firmy PROFIT System, polski rynek franczyzy osiągnął fazę dojrzałości. Od 2003 do 2014 roku liczba marek franczyzowych wzrosła z 213 do 1 058, a liczba placówek franczyzowych z 11882 do 63 367. W 2014 roku rozwój przez franczyzę rozpoczęły kolejne 143 firmy, a 63 poniosły porażkę. Przybyło zatem 80 franczyzodawców, o 28 więcej niż w 2013 roku, http://franchising.pl/artykul/8420/tysiac-pomyslow-biznes-2014-roku/ [30.04.2015]. 
takie potwierdza, że proces powstawania grup zakupowych to bez wątpienia słuszny kierunek w tzw. „globalnej wiosce”. Z uwagi na wspomnianą chęć doskonalenia łańcucha dostaw, sprzyjające otoczenie, korzyści finansowe wynikłe z optymalizacji zakupów i dodatkowo wsparcie ze strony UE, należy się spodziewać, iż grupy zakupowe dość szybko wpiszą się na stałe w struktury łańcuchów MŚP, a wszelkie działania skupione zostaną na podniesieniu ich skuteczności prowadzącej do optymalizacji procesów czy sprawności organizacyjnej.

\section{Bibliografia}

Aigrain P., Dzielenie się. Kultura i gospodarka epoki Internetu, Fundacja Nowoczesna Polska, Warszawa 2012.

Bartkowiak P., Domański J., Szpitalne Grupy Zakupowe w kształtowaniu łańcucha wartości na rynku ustug szpitalnych [w]: A. Marjański (red.) Przedsiębiorczy Menedżer Przedsiębiorczej Organizacji, Nowoczesne tendencje w nauce oraz w praktyce organizacji i zarządzania, „Przedsiębiorczość i Zarządzanie", tom XIV, zeszyt 3, Łódź 2013.

Bernatek G., Konarzewski E., Efektywność zakupu energii elektrycznej w Jednostkach Samorządu Terytorialnego, Raport z badania Audytel przeprowadzonego we współpracy ze Związkiem Powiatów Polskich, czerwiec, 2013.

Drucker P., Innowacja i przedsiębiorczość. Praktyka i zasady, PWE, Warszawa 1992.

Drucker P., Myśli przewodnie Druckera, „MT Biznes”, Warszawa 2002.

Ghaderi H., Leman Z., Horizontal collaboration in purchasing: A successful case from small and medium enterprises (SMEs), „African Journal of Business Management”, Vol. 7(10), 2013 s. 750-753. Gray K., Buying Groups and Trends in Demand Aggregation, VP Corporate Strategy, 2006.

Kaszyński W., Federowski J., Szpitalne grupy zakupowe. Wspólnymi siłami, „Menedżer zdrowia”, nr 10, 2011.

Khalid S., The True Value of GPOs and Purchasing Consortiums, „Instasupplay”, nr 10, 2014.

Kirner E., Som O., Dreher C., Wiesenmaier V., Innovation in KMU - Der ganzheitliche Innovationsansatz und die Bedeutung der Innovationsroutinen für den Innovationsprozess, „Fraunhofer Institut System - und Innovationsforschung", 2006.

Kolińska K., Doliński D., Grupowe zakupy materiałów jako sposób na obniżenie kosztów przedsiębiorstwa, „Logistyka-nauka”, nr 5, 2013.

Penc J., Innowacje i zmiany w firmie, AW Placet, Warszawa 1999.

Pieńkowska M., Innowacyjność przedsiębiorstw przemysłowych, [w:] Raport o innowacyjności gospodarki Polski w 2009 roku, (red.) T. Baczko, PAN, Warszawa 2010.

Sadler D., How Group Purchasing Can Mean Big Savings for Small Businesses, 2012, www.allbusiness. com/how-group-purchasing-can-mean-big-savings-for-small-businesses-15037283-1.html.

Siedzieniewski M., Jak zaryzykować i pociagnąć resztę, „Miesięcznik Dealer”, 20 lipca 2011.

Szymańska A. I., Innowacyjność produktowa przedsiębiorstw produkcyjnych a preferencje konsumentów [w:] Wpływ innowacyjności na rozwój przedsiębiorstw, (red.) Z. Zioło, T. Rachwał, Prace Komisji Geografii Przemysłu nr 19, Kraków 2012.

Wrońska E. M., Teoria kosztów transakcyjnych a grupy zakupowe, „Annales Universitatis Mariae Curie-Skłodowska", Lublin-Polonia, VOL. XLVI, 1, 2012.

Wyżnikiewicz B., Polskie MŚP na drodze ku nowoczesności, Instytut Badań nad Gospodarką Rynkową, 2013.

Zięba M., Oster P., Innowacyjność w małych i średnich przedsiębiorstwach, „E-mentor”, nr 3, 2011.

Raport o franczyzie w Polsce, PROFIT System, 2015. 
www. v123235.home.net.pl [23.04.2015]. www.apug.com [11.11.2015].

www.dzienniklodzki.pl/artykul/3779083,lodzka-grupa-zakupowa-lodz-oszczedzila-na-pradzie8-mln-zl,id,t.html [20.12.2015].

www.ec.europa.eu/enterprise/policies/sme [07.04.2015].

www.forbes.pl/tanszy-prad-dla-firm-w-grupach-akupowych,artykuly, 1647 15,1,1.html [24.11.2015].

www.forsal.pl/artykuly/726407,siec-franczyzowa-grupa-zakupowa-wady-zalety.html [20.04.2015]. www.franchising.pl/artykul/8420/tysiac-pomyslow-biznes-2014-roku [30.04.2015].

www.klaster.kalisz.pl/aktualnosci [30.11.2015].

www.log24.pl/artykuly/zakupy-kluczem-do-sukcesu,27639 [20.12.2015].

www.suwalki24.pl/mobile/article/1,_polska_wraca_do_komunizmu_ekonomia_sharing_w_natarciu [19.11.2015]. 

Aleksandra Reńda, Anita Sieradzka
Uniwersytet Łódzki
Wydział Ekonomiczno-Socjologiczny
ul. POW 3/5, 90-255 Łódź

\section{Metody doskonalenia procesów i produktów na przykładzie japońskich technik zarządzania}

\section{WPROWADZENIE}

W celu optymalizacji efektów zarządzania menedżerowie sięgają po techniki zarządzania z całego świata. Najbardziej znanymi są techniki japońskie zyskujące coraz większą popularność. Japońska gospodarka rozwijała się zupełnie innymi drogami niż w państwach zachodnich, cechuje ją oryginalność, logiczność oraz wyjątkowa skuteczność. Zainteresowanie tymi technikami skłoniło nas do zagłębienia się w szczegóły niektórych z nich i przybliżenie ich czytelnikowi. W niniejszym rozdziale przedstawimy niektóre japońskie techniki zarządzania takie, jak: Just in Time, Kaizen, Lean Management, TQM i 5S. W kolejnych podrozdziałach zostaną opisane zasady posługiwania się nimi oraz nasza osobista ocena w postaci analizy SWOT. Na początku jednak przedstawimy krótkie rozeznanie w temacie.

\subsection{WSTĘP}

Podstawą prowadzenia każdej działalności powinien być rozwój i dążenie do bycia liderem w swojej dziedzinie. Bycie zauważonym w dzisiejszym świecie również jest bardzo trudne. Udało się to już w XX wieku japońskim przedsiębiorstwom. Podczas, gdy amerykańskie i europejskie przedsiębiorstwa skupiały się na zwiększaniu wydajności i szybkości, japońskie firmy postawiły na niekonwencjonalną wtedy metodę zarządzania, czyli na minimalizację - zasobów, czynności zbędnych, magazynowania, ruchu itd. $\mathrm{W}$ ich sposobie było więcej zrozumienia dla pracowników, nieskupianie się na ilości a jakości, a mimo to jednocześnie osiągnęli tak dobre wyniki sprzedażowe. Był to czynnik, dzięki któremu inni producenci zauważyli potencjał japońskich technik zarządzania. Dokładne rozgraniczenie wszystkich metod i technik japońskich i zhierarchizowanie ich jest niemal niemożliwe. Obrazem próby ich uszeregowania jest Tabela 1. Tak, jak w wielu pozycjach książkowych przyjmuje się Kaizen i Lean Management jako wiodące podejścia do zarządzania, które się podstawą dla reszty. Te dwie koncepcje realizowane są poprzez inne metody. Przykładem jest Lean Management, które może być realizowany przez zastosowanie metody Just in Time wykorzystującej narzędzia 
takie, jak np. kanban czy poka-yoke. Jednak najczęściej każda technika czy metoda powiązana jest $\mathrm{z}$ inną metodą, przez co możemy zauważyć, że ich wprowadzanie jest często lączne ${ }^{1}$.

Tabela 1. Japońskie koncepcje, metody i techniki zarządzania na poszczególnych poziomach zarządzania

\begin{tabular}{|c|c|}
\hline Poziom 1 & Kaizen \\
Koncepcja (filozofia, orientacja, podejście) & Lean Management \\
\hline Poziom 2 & Just in Time \\
Metoda (metoda ogólna) & Hoshin kanri \\
\hline Poziom 3 & Kaizen \\
Technika (metoda szczegółowa, technika, & Kanban \\
narzędzie) & Andon \\
& Poka-yoke \\
& Koła jakości \\
& 5 S \\
\hline
\end{tabular}

Źródło: M. Krasiński, Kulturowe uwarunkowania wykorzystania japońskich koncepcji, metod i technik zarządzania, Wydawnictwo Uniwersytetu Ekonomicznego we Wrocławiu, Wrocław 2014, s. 12.

Każda z niżej omówionych technik jest ukierunkowana na podnoszenie satysfakcji, dopasowanie do wymagań klienta, jak również na minimalizację dostępnych zasobów i maksymalizację jakości. Jest to satysfakcja nie tylko klienta, przez którego głównie powinien być oceniany każdy proces zarządzania, ale i satysfakcja pracowników, a nawet kierownictwa i zarządu².

\section{1.2. KAIZEN}

Metoda Kaizen, najbardziej rozpowszechniona w Japonii, nastawiona jest na doskonalenie procesów i sposobów zarządzania, a nie jak w Europie na ocenę wyników końcowych. Kaizen jest często prekursorem każdej zmiany i wprowadzenia każdej z najmniejszych technik. Pod tym pojęciem możemy rozumieć akceptację obecnej pracy przedsiębiorstwa i jej doskonalenie. Kaizen oznacza małe usprawnienia, wdrażane stopniowo, ciągle, które razem dają widoczne efekty, co nie powoduje konieczności wprowadzania radykalnych i często bardzo kosztownych zmian. Jednakowoż efekt tych małych, niepozornych zmian jest powodem zwiększenia satysfakcji klienta, a co z tym się wiąże sukcesu przedsiębiorstwa na rynku³.

\footnotetext{
${ }^{1}$ M. Krasiński, Kulturowe uwarunkowania wykorzystania japońskich koncepcji, metod i technik zarzadzania, Wydawnictwo Uniwersytetu Ekonomicznego we Wrocławiu, Wrocław 2014, s. 13.

${ }^{2}$ http://www.log24.pl/artykuly/kaizen-to-dna-toyoty,3152 [06.01.2016].

${ }^{3} \mathrm{http}: / /$ piotr-kuras.w.interiowo.pl/kaizen.htm [12.12.2015].
} 
11. METODY DOSKONALENIA PROCESÓW I PRODUKTÓW NA PRZYKŁADZIE JAPOŃSKICH TECHNIK...

Celem tej metody jest dążenie do ulepszania przez każdego pracownika możliwie jak najczęściej, nawet jeżeli dotyczy to malutkich zmian. Warunkiem sukcesu, jak przy każdej metodzie, jest zaangażowanie kadry kierowniczej przedsiębiorstwa w metodę Kaizen.

Tak, jak każda koncepcja, Kaizen ma swoje wady i zalety. Najważniejsze zostały wskazane $\mathrm{w}$ tabeli 2 . Według polskich przedsiębiorców i również innych europejskich producentów efekty każdej zmiany powinny być natychmiastowe, a bynajmniej szybko widoczne. Japońskie techniki charakteryzują się stopniowymi i małymi krokami zmian, a skutki ich wprowadzenia nie są gwałtowne, przez co wydają się mało skuteczne. Zalety, jakie posiada ta metoda i bonusy, jakie może uzyskać dzięki Kaizen przedsiębiorstwo, powinny wynagrodzić wszelkie niedogodności ${ }^{4}$.

Szablonowym wzorem wykorzystania oraz rozpowszechnienia Kaizen jest Toyota. Jako pierwsi wprowadzili zasady Kaizen i na bieżąco dopracowywali funkcjonowanie. Toyota, jako jedno z japońskich przedsiębiorstw, kładzie bardzo duży nacisk na stosowanie tej metody ${ }^{5}$.

Tabela 2. Analiza SWOT Kaizen

\begin{tabular}{|c|c|}
\hline Zalety & Wady \\
\hline $\begin{array}{l}\text { - Wdrażanie tej koncepcji przebiega bez } \\
\text { „dramatycznych napięć”. } \\
\text { - Nie wymaga nowoczesnych technologii. } \\
\text { - Posługuje się prostymi narzędziami. } \\
\text { - Nie ma obowiązku wprowadzania Kaizen } \\
\text { w całym przedsiębiorstwie. } \\
\text { - W większości problemów można je } \\
\text { rozwiązać za pomocą metody Kaizen. }\end{array}$ & $\begin{array}{l}\text { - Mało widoczne efekty (bezpośrednie i szybkie). } \\
\text { - Długotrwały proces. } \\
\text { - Konieczność zwracania uwagi na każdy, nawet } \\
\text { drobny, detal. }\end{array}$ \\
\hline Szanse & Zagrożenia \\
\hline $\begin{array}{l}\text { - Uzyskanie przewagi nad konkurentami. } \\
\text { - Podniesienie zaufania ze strony klientów. }\end{array}$ & $\begin{array}{l}\text { - Przy dłuższym stosowaniu tej metody może po- } \\
\text { jawić się niechęć do dalszej kontynuacji ciągłe- } \\
\text { go doskonalenia tłumacząc, że wszystko zostało } \\
\text { udoskonalone. }\end{array}$ \\
\hline
\end{tabular}

Źródło: opracowanie własne na podstawie: http://filozofiakaizen.blox.pl/2015/09/Narzedzia-KAIZEN.html [07.01.2016].

${ }^{4}$ http://filozofiakaizen.blox.pl/2015/09/Narzedzia-KAIZEN.html [07.01.2016].

${ }^{5} \mathrm{http} / / /$ www.log24.pl/artykuly/kaizen-to-dna-toyoty,3152 [28.12.2015]. 


\subsection{KoŁa JAKOści ${ }^{6}$}

Dobrym sposobem doskonalenia pracy w przedsiębiorstwie jest wprowadzenie kół jakości. Jest on prawie nieodłącznym elementem koncepcji Kaizen, jak i stosowania techniki TQM. Są to niewielkie grupy osób regularnie się spotykających w celu rozwiązywania problemów jakości produktów. Obok jakości, koła zwracają również uwagę na inne ważne aspekty produkcyjne, jak: koszty, wyposażenie, a nawet bardzo istotne bezpieczeństwo. Każde koło powinno mieć swojego „lidera oraz wyszkolonych liderów grup inicjujących działania”.

Jednym z przykładów wdrożenia kół jakości była Toyota, dzięki której zostały one rozpowszechnione i uznane przez pozostałych japońskich przedsiębiorców. Tabela 3 przedstawia wady i zalety kół jakości.

Tabela 3. Analiza SWOT kół jakości

\begin{tabular}{|c|c|}
\hline Zalety & Wady \\
\hline $\begin{array}{l}\text { - Brak potrzeby zatrudniania specjalistów do } \\
\text { znajdowania problemów, gdyż pracownicy } \\
\text { najniższego szczebla widzą je lepiej od osób } \\
\text { trzecich. }\end{array}$ & $\begin{array}{l}\text { - Oczekiwania ze strony pracowników o coraz } \\
\text { większych nagrodach i rosnące ambicje bądź } \\
\text { zmniejszenie zainteresowania kołami jakości } \\
\text { lub całkowite zaprzestanie ich działalności, } \\
\text { gdy najbardziej pochłaniające koszty problemy } \\
\text { zostały rozwiązane. }\end{array}$ \\
\hline Szanse & Zagrożenia \\
\hline $\begin{array}{l}\text { - Polepszenie komunikacji w przedsiębior- } \\
\text { stwie. } \\
\text { - Zwiększenie popularności pracy zespołowej. } \\
\text { - Większe zaangażowanie pracowników po- } \\
\text { przez możliwość zaproponowania własnych } \\
\text { pomysłów zmian i poczucie ważności. }\end{array}$ & $\begin{array}{l}\text { - Brak odpowiedniej wiedzy i informacji uczest- } \\
\text { ników kół może doprowadzić do podjęcia nie- } \\
\text { odpowiednich kroków lub złego sprecyzowa- } \\
\text { nia problemu. } \\
\text { - Możliwość napotkania oporu ze strony kierow- } \\
\text { nictwa oraz pracowników, którzy będą powią- } \\
\text { zani bezpośrednio ze zmianami ustalonymi } \\
\text { przez koła jakości. }\end{array}$ \\
\hline
\end{tabular}

Źródło: opracowanie własne na podstawie: H. Obora, Japońska metodyka rozwiązywania problemów QC-Story, [w:] Historia i perspektywy nauk o zarzadzaniu, (red.) B. Mikuła, Fundacja Uniwersytetu Ekonomicznego w Krakowie, Kraków 2012, s. 393-394.

\section{4. $\mathrm{TQM}^{7}$}

Total Quality (Control) Management, czyli kompleksowe zarządzanie jakością, jest koncepcją zarządzania skupioną wokół jednego aspektu - jakości. Skoncentrowanie działań na tym polu ma za zadanie zadowolenie wszystkich uczestników

\footnotetext{
${ }^{6}$ M. Krasiński, op. cit., s. 50-51.

${ }^{7}$ http://tqm.blox.pl/html [18.12.2015].
} 
łańcucha logistycznego, a w szczególności zadowolenie klienta, którego satysfakcja z nabycia dobra lub usługi jest jedną z najważniejszych.

Bardzo istotne $\mathrm{w}$ tym podejściu jest zdefiniowanie potrzeb odbiorców, co pomoże określić kierunek jakości. Pomocne może być tu zidentyfikowanie mierników jakości (mimo, że ogólny zarys TQM tego nie przewiduje). Różnego rodzaju mierniki bądź wskaźniki mają kontrolować zmiany, obecnego stanu, sprawdzać czy zmiany, jakie wprowadza przedsiębiorstwo, dają jakiekolwiek postępy. Zarządzanie jakością nie posiada ściśle stosowanej metodyki działania i wdrażania, co sprawia trochę problemów menedżerom. Oprócz tych niedogodności niezachęcający jest również łączny czas tworzenia i wprowadzenia projektu, który najczęściej może trwać kilka lat. Niechętni są również akcjonariusze, którzy są świadomi konieczności ponoszenia kosztów przez firmę, a przecież przychody nie będą w najbliższym czasie wzrastać. Te i pozostałe wady zawiera Tabela 4.

Tabela 4. Analiza SWOT TQM

\begin{tabular}{|c|c|}
\hline Zalety & Wady \\
\hline $\begin{array}{l}\text { - Lepsza kultura organizacyjna. } \\
\text { - Lepsza produktywność. } \\
\text { - Wzrost zaufania i poczucia wartości pracow- } \\
\text { ników w firmie. }\end{array}$ & $\begin{array}{l}\text { - Pracochłonność. } \\
\text { - Czasochłonność. } \\
\text { - Brak konkretnych mierników oceny efektyw- } \\
\text { ności zmian. }\end{array}$ \\
\hline Szanse & Zagrożenia \\
\hline $\begin{array}{l}\text { - Osiągnięcie długookresowego powodzenia } \\
\text { przedsiębiorstwa. }\end{array}$ & $\begin{array}{l}\text { - Błędne prowadzenie niektórych z elementów } \\
\text { tej koncepcji może doprowadzić do skutków } \\
\text { idących w odwrotnym kierunku niż planowa- } \\
\text { ne. }\end{array}$ \\
\hline
\end{tabular}

Źródło: Opracowanie własne na podstawie: A. Mazur, H. Gołaś, Zasady, metody i techniki wykorzystywane w zarządzaniu jakością, Wydawnictwo Politechniki Poznańskiej, Poznań 2010, s. 22-25.

Jednym z przykładów zastosowania TQM w swojej działalności może być przedsiębiorstwo Zelmer w Rzeszowie, które wprowadziło szereg zmian mających na celu poprawę jakości. Zelmer zaangażował w doskonalenie produktu swoich pracowników poprzez możliwość uczestnictwa w niewielkich grupach zadaniowych, dzięki czemu mogli zgłaszać swoje pomysły. Grupy działały na podobnej zasadzie do kół jakości z wyjątkiem ich celów: celem grup zadaniowych było każde, nawet najmniejsze, usprawnienie jakości. Również nagrody za osiągnięcia w pracy i funkcjonowanie rankingów, które także wiązały się z nagrodami finansowymi, pomagały pracownikom czuć się docenianymi i wartościowymi, jak również zachęcały do dalszej rywalizacji.

${ }^{8}$ J. Malinowska, Praktyka jakości i produktywności - model polski, „Problemy Jakości”, nr 3, 1999, s. 27-31. 


\subsection{LEAN MANAGEMENT}

Koncepcja Lean Management zrodziła się na podstawie Kaizen w koncernie Toyoty. Ogólna zasada polega na doskonaleniu procesów zachodzących w całym przedsiębiorstwie. Szczupłe zarządzanie może dotyczyć każdej części całego łańcucha logistycznego, począwszy od produkcji po transport aż po administrację, a jego działanie jest tym skuteczniejsze, im więcej elementów łańcucha logistycznego go stosuje. Przedsiębiorstwa stosujące tę koncepcję skupiają się na efektywnym zmniejszaniu kosztów, czasu realizacji, a także na podniesieniu jakości dla klienta. Straty, jakie przedsiębiorstwo może generować, mogą dotyczyć takich obszarów, jak: nadprodukcja, produkcja braków, utrzymywanie zbędnych zapasów, stosowanie niewłaściwych metod wytwarzania, nadmierny transport między stanowiskami, przestoje, zbędny ruch czy niewykorzystany potencjał pracowników ${ }^{9}$.

Całkowite „odchudzanie” przedsiębiorstwa kojarzone jest również z odchudzaniem załogi. Pracownicy są niechętnie nastawieni albo ze względów złego wykorzystania (szybsza lub wydajniejsza praca pracowników zamiast wykorzystania ich potencjału intelektualnego bądź innych zdolności) albo ze spodziewanych zwolnień (tabela 5.). Najtrudniejszą do osiągnięcia jest zmiana tej mentalności na pozytywną, ale osiągnięcie wybranego celu gwarantuje lepszą komunikację pracowników na odmiennych szczeblach w przedsiębiorstwie ${ }^{10}$.

Tabela 5. Analiza SWOT Lean Management

\begin{tabular}{|c|c|}
\hline Zalety & Wady \\
\hline $\begin{array}{l}\text { - Redukcja kosztów, zmniejszenie rozrzutności. } \\
\text { - Zwiększenie wydajności pracy. } \\
\text { - Lepsza komunikacja między kierownikami } \\
\text { a podwładnymi. } \\
\text { - Większa tożsamość pracowników z firmą. }\end{array}$ & $\begin{array}{l}\text { - Powierzchowna redukcja liczby } \\
\text { pracowników. } \\
\text { - Wzrost zapotrzebowania na siły facho- } \\
\text { we. }\end{array}$ \\
\hline Szanse & Zagrożenia \\
\hline $\begin{array}{l}\text { - Przy właściwej organizacji procesów możliwa jest } \\
\text { całkowita eliminacja niepotrzebnych elementów } \\
\text { i skupienie się tylko i wyłącznie na niezbędnych } \\
\text { i przynoszących wartość dodaną czynnościach. }\end{array}$ & $\begin{array}{l}\text { - Złe wykorzystywanie przez zarząd kon- } \\
\text { cepcji, np. ciągłe zwiększanie wydajności } \\
\text { jednego człowieka poprzez zwiększanie } \\
\text { norm produkcyjnych zamiast wykorzy- } \\
\text { stania w pełni potencjału pracowników. }\end{array}$ \\
\hline
\end{tabular}

Źródło: opracowanie własne na podstawie: http://www.log24.pl/artykuly/zderzenie-kultur-biznesowych,2250 [09.01.2016].

\footnotetext{
${ }^{9}$ M. Krasiński, op. cit., s. 29-31; http://www.logistics.dbschenker.pl/log-pl-pl/start/o-firmie/aktualnosci/spotkanie_z_masaaki_imai_lean.html [07.01.2016].

${ }^{10} \mathrm{http} / / / w w w . l o g 24 . p l / a r t y k u l y / z d e r z e n i e-k u l t u r-b i z n e s o w y c h, 2250$ [09.01.2016].
} 
O zaletach wykorzystania szczupłego odchudzania przekonała się firma transportowa DB Schenker. Włączając Lean Management jako filozofię działania, skupia się na stałym rozwoju i doskonaleniu procesów. Wraz z drugim programem (EFQM) stanowią zunifikowaną strategię zarządzania firmą ${ }^{11}$.

\section{1.6. JUST IN TIME}

Just in Time (dokładnie na czas, dalej JIT) jest używane $\mathrm{w}$ ramach wprowadzania koncepcji Lean Management i ma na celu całkowitą eliminację lub chociaż minimalizację poziomu zapasów. Jest systemem produkcji, w którym przedsiębiorstwo wytwarza i dostarcza produkt lub usługę dokładnie w takiej ilości, jakiej potrzebuje klient oraz na czas i miejsce, jakich wymaga. Aby zapewnić taki precyzyjny przepływ (dobra), konieczna jest zaufana i ścisła współpraca między dostawcą a odbiorcą. Firmy, z którymi jednostka współpracuje w ramach JIT, wraz z danym przedsiębiorstwem muszą mieć wzorową komunikację i możliwość, a nawet konieczność wspólnego rozwiązywania problemów. Taka potrzeba rodzi się ze względu na szybki efekt domina w łańcuchu dostaw, nawet w przypadku minimalnych zmian, na każdym etapie łańcucha. Jednak produkcja bez zapasów jest niemożliwa, więc koszty utrzymania zapasów przenoszą się z magazynu producenta do dostawcy - dostajemy materiały wtedy, kiedy są one potrzebne, a koszty magazynowania, których jednostka fizycznie nie płaci, włączone są do ceny zakupu materiałów.

A co, jeśli jakaś czynność nie zostanie wykonana lub jej wykonanie będzie bardzo odbiegało od normy? Równie kluczową sprawą we wdrażaniu JIT jest plan awaryjny. Jednostka, a nawet cała sieć kooperujących ze sobą firm, powinna mieć pewien plan działania na wypadek wyjątkowych sytuacji. Nie jest możliwym prowadzenie działalności bez żadnych odchyleń, a jeśli tej działalności towarzyszy metoda Just in Time, odchylenia te są bardzo groźne i tuż przed wprowadzeniem w życie metody, musi zostać przeanalizowana każda ewentualność powstała w firmie czy nawet u dostawcy.

Najbardziej znanym i często przywoływanym przykładem zastosowania metody JIT jest General Motors. Amerykański gigant nie przewidział planu na żadną przypadłość losową, przez co w momencie strajku pracowników swojego dostawcy oprócz kompletnego paraliżu i straty finansowej, dostali rykoszetem również inni kooperanci i dostawcy.

Duża część producentów czy usługodawców rezygnuje z pomysłu zastosowania tej metody z obawy przed niepowodzeniem. Tabela 6 obrazuje najbardziej charakterystyczne cechy JIT, którymi kierują się jednostki dokonujące decyzji o jej wprowadzeniu. Jest to najbardziej ryzykowna metoda wśród wymienionych

\footnotetext{
${ }^{11}$ http://www.dbschenker-student.pl/schenkeroteka/poznaj-swiat-db-schenker/filozofia-dzialania/ marnotrawstwu-mowimy-nie [07.01.2016].
} 
w niniejszej pracy. Po jej wdrożeniu istnieje wiele obszarów, które mogą się potoczyć niezgodnie $z$ planem, a raczej z zamysłem ideału. Tak wiele planów awaryjnych, jakie muszą zostać stworzone, wymaga długiego i dużego nakładu pracy i organizacji, a przecież nie wszystko da się przewidzieć. Fakty późniejszego skrócenia czasu produkcji i większej powierzchni do zagospodarowania nie przekonują do poddania się temu w stu procentach.

Tabela 6. Analiza SWOT Just In Time

\begin{tabular}{|c|c|}
\hline Zalety & Wady \\
\hline $\begin{array}{l}\text { - Bliższe i zaufane kontakty } \mathrm{z} \text { do- } \\
\text { stawcami (zazwyczaj jeden } \mathrm{z} \\
\text { większymi partiami dostaw). }\end{array}$ & $\begin{array}{l}\text { - Duże problemy w ciągłości produkcji rodzące się nawet } \\
\text { przez drobne przerwy w dostawach, błędy w dostawach, } \\
\text { niższą jakość materiałów lub nieterminowość dostaw. } \\
\text { - Brak możliwości szybkiej reakcji lub niewielka reakcja na } \\
\text { nagły wzrost popytu na produkt. } \\
\text { - Brak gwarancji powodzenia i najtrudniejsza w realizacji. }\end{array}$ \\
\hline Szanse & Zagrożenia \\
\hline $\begin{array}{l}\text { - Skraca się czas kierowania pro- } \\
\text { dukcją. } \\
\text { - Redukcja czasu czynności poza- } \\
\text { procesowych. } \\
\text { - Obniżenie zapasów produkcji } \\
\text { w toku. } \\
\text { - Zwiększenie powierz- chni użyt- } \\
\text { kowej do produkcji przez czę- } \\
\text { ściową lub całkowitą eliminację } \\
\text { magazynu. }\end{array}$ & $\begin{array}{l}\text { - Dobór nierzetelnych lub nieterminowych dostawców } \\
\text { może być przyczyną zwielokrotnionych kosztów i utraty } \\
\text { klientów. } \\
\text { - Należy mieć plan na każdą ewentualność: nieprzeszkole- } \\
\text { nie kadry kierowniczej nt. zachowania się w awaryjnych } \\
\text { sytuacjach (np. podczas awarii głównej maszyny lub dłuż- } \\
\text { szej przerwy w dostawie prądu) może wywołać groźne } \\
\text { konsekwencje. }\end{array}$ \\
\hline
\end{tabular}

Źródło: opracowanie własne na podstawie: M. Podobiński, Skutki stosowania japońskich koncepcji i metod zarzadzania $w$ polskim przedsiębiorstwie produkcyjnym, „Nauki o zarządzaniu”, nr 1 (18), 2014, s. 81-82.

\section{$11.7 \cdot 5 \mathrm{~S}$}

Metoda 5S jest dość często spotykana w towarzystwie Just in Time i jest jedną z najłatwiejszych metod do wdrożenia w ramach szczupłego zarządzania. Zakłada się w niej odpowiednią organizację każdego miejsca pracy. Nazwa pochodzi od pierwszych liter określeń, które tworzą tę zasadę ${ }^{12}$ :

- Seiri (sortowanie - oznacza podzielenie wszystkich przedmiotów wokół danego stanowiska na zbędne i potrzebne; zbędne są usuwane),

- Seiton (porządkowanie - jest to ułożenie przedmiotów potrzebnych w taki sposób, aby można je łatwo odnaleźć; każdy przedmiot ma swoje stałe położenie i dokładne oznakowanie),

\footnotetext{
${ }^{12} \mathrm{http}: / /$ piotr-kuras.w.interiowo.pl/5s.htm [15.12.2015].
} 
- Seiso (sprzątanie - po wykonanej pracy pracownik ma obowiązek oczyścić wszystkie narzędzia pracy, maszyny na stanowisku oraz stanowisko),

- Seiketsu (standaryzacja - stosowane zasady muszą być wykorzystywane w sposób ciągły, a nie od czasu do czasu),

- Shitsuke (samodyscyplina - to zmiana podejścia pracowników tak, aby stosowanie tych 5 zasad było odruchem bezwarunkowym).

Stosowanie zasady $5 \mathrm{~S}$ powinno być obowiązkowe i dokładnie praktykowane przez każdego pracownika, niezależnie w jakiego rodzaju firmie pracuje. Doskonale się sprawdza nie tylko przy stanowiskach pracowników fizycznych, ale również przy pracach biurowych czy dotyczących wyjazdów służbowych. W Tabeli 7 opisane zostały dodatnie strony wprowadzenia tego narzędzia. Według naszej opinii te zasady nie generują żadnych poważnych zagrożeń, a jedynie szanse lepszej, bezpieczniejszej i bardziej uporządkowanej pracy. Jedynym minusem może być zapał pracowników, dzięki któremu pracownicy mogą uznać pojedyncze zasady za niepotrzebne (np. sprzątanie, „bo za moment i tak się nabrudzi”).

Technikę 5S wykorzystała m.in. Grupa Paradyż. Po dużym wysiłku i zaangażowaniu wszystkich pracowników udało się uporządkować stanowiska pracy (np. przygotowano szafki na narzędzia i pojemniki na odpady) i poprawić bezpieczeństwo pracy. Co najważniejsze, zmieniły się mentalność i złe nawyki pracowników ${ }^{13}$.

Tabela 6. Analiza SWOT 5S

\begin{tabular}{|l|c|}
\hline \multicolumn{1}{|c|}{ Zalety } & \multicolumn{1}{|c|}{ Wady } \\
\hline $\begin{array}{l}\text { - Lepsza higiena i porządek pracy oraz zmiana po- } \\
\text { strzegania miejsca pracy jako schludnego, a tym } \\
\text { samym lepsze samopoczucie pracowników. }\end{array}$ & $\begin{array}{l}\text { - Niepozorność tej metody skłania pracow- } \\
\text { ników do omijania niektórych czynności } \\
\text { lub zupełnego braku zaangażowania z po- } \\
\text { wodu „ważniejszych prac”. }\end{array}$ \\
\hline \multicolumn{1}{|c|}{ Szanse } & \multicolumn{1}{|c|}{ Zagrożenia } \\
\hline $\begin{array}{l}\text { - Poprawa jakości produktu. } \\
\text { - Redukcja liczby wypadków w pracy. } \\
\text { - Redukcja zbędnych działań i ruchów. }\end{array}$ & \\
\hline
\end{tabular}

Źródło: Ibidem.

${ }^{13} \mathrm{http} / / /$ www.jakosc.biz/praktyczne-aspekty-wdrazania-praktyk-5s-w-przemysle-produkcji-pytek-ceramicznych/ [05.01.2016]. 


\subsection{ANALiza OMÓWIONYCH TECHNiK}

Najlepszym zobrazowaniem wpływu wdrożenia którejkolwiek z metod czy technik jest tabela 8 . Zawiera ona wady i zalety, jakie posiadają omówione metody. Łatwo zauważyć najczęściej przejawiające się w poprzednich analizach cechy takie, jak: brak konieczności posługiwania się nowoczesnymi technologiami (niekosztowny w utrzymaniu), posługuje się nieskomplikowanymi narzędziami oraz wymagany jest dłuższy okres, aby zauważyć efekty. Największe ryzyko, którego eliminacji nie da się wykluczyć, budzi nierozsądne lub błahe podejście do metod. Gdy ktoś planuje tylko ogólnie przebieg całego procesu tak, jak GM, może odczuć nieprzyjemne skutki finansowe i spadek reputacji.

Tabela 8. Analiza SWOT omówionych technik japońskiego zarządzania

\begin{tabular}{|c|c|}
\hline Zalety & Wady \\
\hline $\begin{array}{l}\text { - Nie wymaga nowoczesnych technologii. } \\
\text { - Posługuje się prostymi narzędziami. } \\
\text { - Nawet przedsiębiorstwa zajmujące się bardziej } \\
\text { zróżnicowanymi zleceniami (zazwyczaj mają po- } \\
\text { dobne reguły przygotowywania) mogą używać tych } \\
\text { metod. } \\
\text { - Stałe efekty (przy ciągłym stosowaniu). }\end{array}$ & $\begin{array}{l}\text { - Wyniki widoczne w dłuższym okresie } \\
\text { i nie tak efektowne jak po wprowadzeniu } \\
\text { innowacji. } \\
\text { - Wprowadzane zmiany najlepiej wdrażać } \\
\text { stopniowo, niezbyt dużo jednocześnie. } \\
\text { - Możliwość wprowadzenia jedynie } \\
\text { w przedsiębiorstwie ustabilizowanym } \\
\text { finansowo. } \\
\text { - Obawy pracowników przed masowymi } \\
\text { zwolnieniami. }\end{array}$ \\
\hline Szanse & Zagrożenia \\
\hline $\begin{array}{l}\text { - Większa konkurencyjność przedsiębiorstwa. } \\
\text { • Podniesienie zaufania klientów. }\end{array}$ & $\begin{array}{l}\text { - Zastosowanie niezgodne z założeniami } \\
\text { którejś z metod może prowadzić do po- } \\
\text { ważnych skutków. }\end{array}$ \\
\hline
\end{tabular}

Źródło: opracowanie własne na podstawie: M. Krasiński, op. cit., s. 16-50.

\section{Podsumowanie}

Japońskie koncepcje zarządzania powstały w Japonii w II poł. XX wieku, a mimo to nadal są aktualne i na przekór przekonaniu o wyczerpaniu tematu oraz licznym publikacjom na ten temat, nadal nie są powszechnie znane i wykorzystywane. Każda $\mathrm{z}$ omówionych metod i technik, na pozór łatwa i niezbyt skomplikowana, jest ciężka w utrzymaniu przez przedsiębiorstwo, a najtrudniejszą właściwością dla właścicieli polskich przedsiębiorstw jest ich „niepolskość. Jednak niektórzy $\mathrm{z}$ nich zaryzykowali i wprowadzając je w system zarządzania, usprawnili działanie swoich firm, a tym samym efektywność zarządzania łańcuchem lo- 
gistycznym. W takim konkurencyjnym świecie, w jakim żyjemy, tradycyjne podejście sprawdza się tylko w krótkim czasie lub ma zastosowanie w przypadku mało ambitnych przedsiębiorstw. Każda z metod i technik japońskich jest szansą na przełamanie barier. Zaangażowanie się zarządu i jego pilotaż we wprowadzaniu poszczególnych zasad są niezwykle ważne przez cały okres. Pracownicy na każdym stanowisku powinni przechodzić szkolenia w zakresie danych technik, aby nie dochodziło do błędów spowodowanych niewiedzą.

Mimo wszystkich wad i zagrożeń, warto jest wpoić w przedsiębiorstwo mentalność japońskich technik. Nawet nie dzięki korzyściom finansowym, ale i zdrowemu podejściu do pracy. W polskich przedsiębiorstwach nadal panuje przekonanie, że aby być liderem, trzeba produkować więcej, nie zważając na łamanie przepisów (idealny przykład kierowców samochodów ciężarowych). Taki „wyścig szczurów" ani nie jest korzystnym dla pracowników, ani dla pracodawców.

\section{Bibliografia}

Jędrzejak A., Mazur A., Piotrowska M., Praktyczne aspekty wdrażania metody 5S, „Zeszyty Naukowe Politechniki Poznańskiej. Organizacja i zarządzanie”, nr 62, 2014.

Krasiński M., Kulturowe uwarunkowania wykorzystania japońskich koncepcji, metod i technik zarządzania, Wydawnictwo Uniwersytetu Ekonomicznego we Wrocławiu, Wrocław 2014.

Malinowska J., Praktyka jakości i produktywności - model polski, „Problemy Jakości”, nr 3, 1999.

Mazur A., Gołaś H., Zasady, metody i techniki wykorzystywane w zarządzaniu jakością, Wydawnictwo Politechniki Poznańskiej, Poznań 2010.

Obora H., Japońska metodyka rozwiązywania problemów QC-Story, [w:] Historia i perspektywy nauk o zarządzaniu, (red.) Mikuła B., Fundacja Uniwersytetu Ekonomicznego w Krakowie, Kraków 2012.

Podobiński M., Skutki stosowania japońskich koncepcji $i$ metod zarządzania $w$ polskim przedsiębiorstwie produkcyjnym, „Nauki o zarządzaniu”, nr 1 (18), 2014.

http://lean-management.pl/lean-manufacturing.html [07.01.2016].

http://www.dbschenker-student.pl/schenkeroteka/poznaj-swiat-db-schenker/filozofia-dzialania/marnotrawstwu-mowimy-nie [06.01.2016].

http://www.jakosc.biz/praktyczne-aspekty-wdrazania-praktyk-5s-w-przemysle-produkcji-pytekceramicznych/ [05.01.2016].

http://www.log24.pl/artykuly/zagrozenia-lean-manufacturing,1579 [09.01.2016].

http://www.log24.pl/artykuly/zderzenie-kultur-biznesowych,2250 [07.01.2016].

http://www.logistics.dbschenker.pl/log-pl-pl/start/o-firmie/aktualnosci/spotkanie_z_masaaki_ imai_lean.html [07.01.2016].

http://piotr-kuras.w.interiowo.pl/kaizen.htm [15.12.2015].

http://piotr-kuras.w.interiowo.pl/5s.htm [15.12.2015].

http://tqm.blox.pl/html [18.12.2015].

http://filozofiakaizen.blox.pl/2015/09/Narzedzia-KAIZEN.html [07.01.2016].

http://www.log24.pl/artykuly/kaizen-to-dna-toyoty,3152 [09.01.2016]. 

Katarzyna Telega

Politechnika Łódzka

Wydział Organizacji i Zarządzania

ul. Piotrkowska 266, 90-924 Łódź

\section{Technologie przewozu i przeładunku elementów elektrowni wiatrowych w lańcuchu dostaw}

\section{WPROWADZENIE}

W dobie wzrastającego wolumenu przewozu ładunków, rosnącej konkurencji dotyczącej szybkości dostaw, znaczącego zanieczyszczenia środowiska, zatłoczenia dróg i przejść granicznych jedynym perspektywicznym rozwiązaniem staje się rozwój technologii przewozów i przeładunków towarów. Współczesne podejście do transportu wymaga kompleksowego spojrzenia na cały łańcuch transportowy. Należy odejść od gałęziowego oceniania transportu, a spojrzeć nań jako na całość.

Celem niniejszego rozdziału jest opisanie i scharakteryzowanie technologii przewozu i przeładunku elementów elektrowni wiatrowych oraz pokazanie, jak istotnym ogniwem są one w sprawnym i efektywnym działaniu łańcucha dostaw.

\subsection{Pojęcie tańcucha dostaw}

Łańcuch dostaw jest definiowany m. in. jako: „działalność związana z przepływem produktów i usług - od jego oryginalnego źródła, przez wszystkie formy pośrednie, aż do postaci, w której produkty i usługi są konsumowane przez ostatecznego klienta. Istota logistyki sprowadza się więc do integrowania zarządzania $z$ tradycyjnymi obszarami produkcji, finansów i marketingu" . Odpowiednie zarządzanie łańcuchem dostaw jest niezbędnym elementem strategii logistycznej, stanowiącej element strategii przedsiębiorstwa, gdyż w sposób bezpośredni oddziałuje na wielkość kosztów, jakość, poziom zapasów, cenę i sposób dostawy. Można zatem zdefiniować je jako „formułowanie strategii, planowanie, sterowanie i kontrolę procesów przepływów i magazynowania surowców, zapasów produkcji w toku, wyrobów gotowych i odpowiednich informacji od punktu pozyskania do punktu konsumpcji w celu jak najlepszego dostosowania się do potrzeb klienta i ich zaspokojenia. Jest istotne, aby proces zarządzania odbywał się w sposób efektywny i prowadził do minimalizacji kosztów globalnych"2.

${ }^{1}$ E. Gołembska, Logistyka w gospodarce światowej, C.H. Beck, Warszawa 2009, s. 137.

${ }^{2} \mathrm{~J}$. Witkowski, Zarzadzanie łańcuchem dostaw. Koncepcje. Procedury. Doświadczenia, PWE, Warszawa 2010, s. 19. 
Wykorzystując podejście W. Walkera można zauważyć, że szybkość działania całego łańcucha dostaw oraz ograniczenie różnic czasów realizacji zadań przez poszczególne ogniwa są bowiem szczególnie istotne z punktu widzenia projektowania łańcucha dostaw, a do podstawowych celów należą zapewnienie konkurencyjnej infrastruktury oraz organizacja logistyki umożliwiająca realizację przepływów dóbr, informacji i środków pieniężnych nawet w skali całego świata. Zapewnienie przepływu informacji w odpowiedniej formie, miejscu i czasie oraz znajomość założeń dotyczących wyników współpracy wpływają przede wszystkim na działalność poszczególnych ogniw w łańcuchu, a realizacja tych zasad powinna ułatwić dostosowanie podaży do popytu, a także pomiar osiągnięć całego łańcucha niezależnie od skali jego działalności. Tworzenie wartości dla interesariuszy wynika natomiast $\mathrm{z}$ założenia, że taka forma współpracy przedsiębiorstw ma umożliwić interesariuszom osiągnięcie wyższych korzyści niż w warunkach odrębnego działania każdego $\mathrm{z}$ nich ${ }^{3}$.

\subsection{TECHNOLOGIE PRZEWOZU ELEMENTÓW ELEKTROWNI WIATROWYCH}

Transport elementów elektrowni wiatrowych nie jest prostym zadaniem, oczywiście z uwagi na ich potężne rozmiary. Szczególnie dużymi elementami są najniższe segmenty samych wież wiatraków, które $z$ uwagi na imponującą średnicę stają się w pozycji leżącej bardzo wysokie. Dlatego też do transportu tych właśnie elementów wykorzystuje się specjalne naczepy, które łapią wieżę w dwa ogromne uchwyty, utrzymując ją praktycznie nad samą ziemią.

\subsubsection{SYSTEM TOWER BRIDGE}

System Tower Bridge został opracowany przez firmę o tej samej nazwie $\mathrm{z}$ holenderskiej miejscowości Woudenberg. Tower Bridge ma umożliwić transport elementów wież wiatraków przy wykorzystaniu „zwykłych”, rozciąganych naczep -platform, które w kilka minut po rozładowaniu przestają przekraczać przepisowe $13,6 \mathrm{~m}$, a ponadto nadają się do całego wachlarza zastosowań.Cała konstrukcja ma trzy główne elementy - dwa uchwyty do wieży, które mocowane są do platformy, a także specjalny wózek gąsienicowy z siodłem i układem zdalnego sterowania. Wózek ma za zadanie przejechać przez wnętrze transportowanego elementu z przednią częścią naczepy, rozciągając ją w ten sposób do żądanej długości. Następnie naczepa rozstawia podpory, wózek odjeżdża, zaś jego miejsce zajmuje siodło ciężarówki. Wózek ładuje się po wszystkim na naczepę i można ruszać przed siebie z wieżą wiszącą przy samej ziemi, ciesząc się z ograniczonej wysokości zestawu. Kiedy natomiast dojedziemy na miejsce, wózek gąsienicowy wycofuje rozcią-

${ }^{3}$ W.T. Walker, Supply Chain Architecture: A Blueprint fir Networking the Flow of Material, Information and Cash, CRC Press LLC, Boca Raton, London, New York, Washington, D.C. 2005, s. 20-24. 


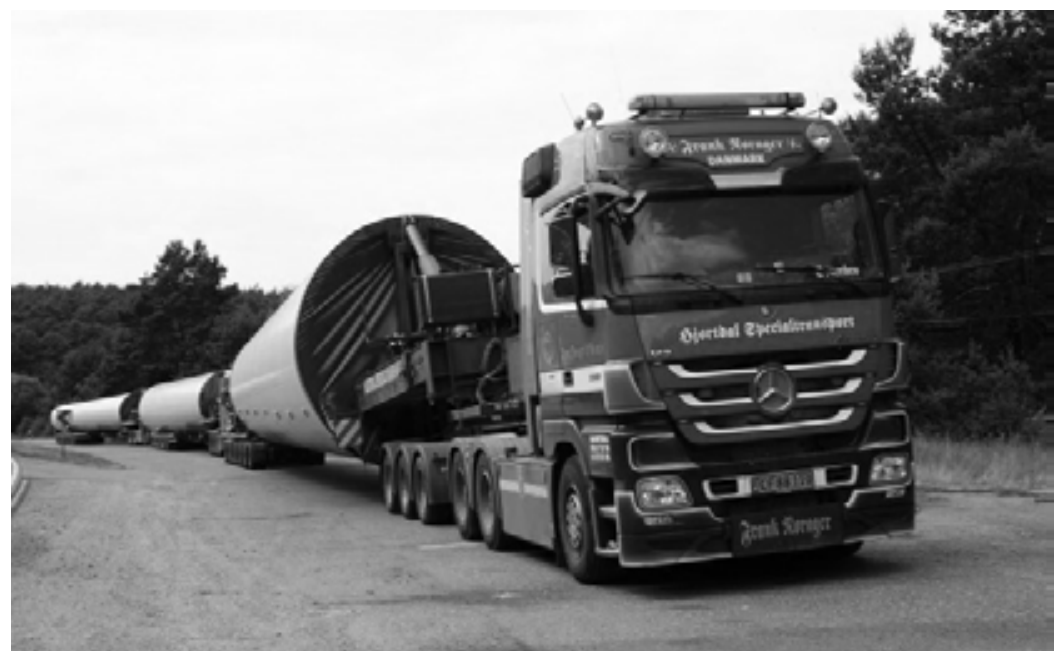

Fotografia 1. Przewóz elektrowni wiatrowej systemem Tower Bridge

Źródło: http://40ton.net/naczepa-transportu-wiez-wiatrakow-ktora-minut-przeksztalca-sie-zwykla -platforme/ [19.02.2016].

gniętą część naczepy przez wnętrze wieży, ładunek zabierają dźwigi, natomiast ciagnik siodłowy może z powrotem podpiąć naczepę, zsunąć jej platformę i ruszyć bez przekraczania dopuszczalnej długości zestawu. Co więcej, w drodze powrotnej na pojazd można załadować inny ładunek, który normalnie spocznie na platformie.

Tower Bridge zostało już wprowadzone do użytku przez firmę transportową Westdijk Transport, która ma swój oddział także w Polsce. Ponadto cały system zaaprobował Bros-huis - producent naczep do transportu ponadgabarytowego, które mają bez problemu współpracować z opisanym powyżej wynalazkiem ${ }^{4}$.

\subsection{UWARUNKOWANIA TECHNICZNE PRZEWOZÓW ELEKTROWNI WIATROWYCH}

Podstawowe ograniczenia techniczne na trasie przejazdu konwoju pojazdów nienormatywnych związane są z obiektami inżynieryjnymi oraz ze złym stanem nawierzchni dróg. W przypadku transportu elektrowni wiatrowych najważniejsze ograniczenia obejmują:

- mosty i estakady ograniczające dopuszczalny nacisk na oś/osie,

- zbyt niskie i wąskie wiadukty,

- ronda o zbyt małym promieniu skrętu i braku możliwości przejazdu na wprost,

4 http://40ton.net/naczepa-transportu-wiez-wiatrakow-ktora-minut-przeksztalca-sie-zwykla-platforme [16.02.2016]. 
- zły stan nawierzchni, nieodpowiadający wartościom projektowym dla danej kategorii,

- ostre leśne zakręty,

- stałe obiekty w zabudowie miejskiej, np. lampy, drogowskazy, reklamy,

- przeprowadzane remonty dróg, itp. ${ }^{5}$

Konieczność identyfikacji, zabezpieczania i usuwania przeszkód drogowych na czas przejazdu konwoju wiąże się ze znaczącymi kosztami. Koszt dostosowania infrastruktury drogowej do przewozu elementów elektrowni wiatrowych przedstawiony zostanie na przykładzie przedsiębiorstwa $\mathrm{X}$, zajmującego się kompleksową realizacją inwestycji budowy farm wiatrowych w Polsce, jak i Europie. Jego oferta obejmuje obsługę logistyczno-techniczną inwestycji na każdym z etapów jej realizacji począwszy od wyboru najkorzystniejszej lokalizacji, poprzez pozyskanie niezbędnych pozwoleń i decyzji administracyjnych, etap budowy, aż do momentu rozpoczęcia eksploatacji elektrowni wiatrowej.

W przedsiębiorstwie zostały zbadane i zestawione wszystkie koszty dostosowania infrastruktury do przewozów elektrowni wiatrowych. Badanie zostało przeprowadzone 14-15 stycznia 2016 roku Analizie został poddany transport jednej elektrowni wiatrowej, transportowanej trzema konwojami. Długość badanej trasy wyniosła $551 \mathrm{~km}$, a długość masztu wiatraka zaś $120 \mathrm{~m}$. Średnie koszty dostosowania infrastruktury drogowej do przewozu jednej elektrowni wiatrowej o wysokości $120 \mathrm{~m}$ pokazuje tabela 1 . Do tych kosztów należy doliczyć opłatę wnoszoną za wydanie zezwolenia w wysokości kilku tysięcy złotych. Koszt zezwolenia jest zależny od długości trasy i wielkości przekroczeń dopuszczalnych parametrów pojazdów.

Tabela 1. Koszty dostosowania infrastruktury drogowej do przewozu jednej elektrowni wiatrowej o długości masztu $120 \mathrm{~m}$ na trasie $551 \mathrm{~km}$

\begin{tabular}{|c|c|c|c|}
\hline Lp. & Opis czynności & Lokalizacja & Koszt $[\mathrm{PLN}]$ \\
\hline 1. & $\begin{array}{l}\text { Objazd trasy poprzedzający trans- } \\
\text { port elementów elektrowni wiatrowej }\end{array}$ & Cała trasa & 4000 \\
\hline 2. & Pilotaż (3 konwoje) & Cała trasa & $3 \times 4000$ \\
\hline 3. & Przycinanie drzew & $\begin{array}{l}7 \text { lokalizacji na drogach } \\
\text { wojewódzkich i powiatowych }\end{array}$ & 50000 \\
\hline 4. & $\begin{array}{c}\text { Nadbudowa drewnem krawężników } \\
\text { na zakrętach }\end{array}$ & 5 lokalizacji & $5 \times 1000$ \\
\hline 5. & $\begin{array}{l}\text { Wyłożenie drogi płytami betonowy- } \\
\text { mi przy wjeździe na farmę }\end{array}$ & Ok. 50 płyt na ostatnich $1,5 \mathrm{~km}$ & 25000 \\
\hline \multicolumn{3}{|c|}{ Razem } & 96000 \\
\hline
\end{tabular}

Źródło: opracowanie własne.

${ }^{5}$ http://www.transannaberg.pl/41/elektrownie-wiatrow [19.02.2016]. 
Jak widzimy w powyższej tabeli, koszty dostosowania infrastruktury drogowej do przewozu jednej elektrowni wiatrowej o długości $120 \mathrm{~m}$ wynoszą 96000 PLN. Świadczy to o tym, że przewóz elektrowni wiatrowej jest bardzo kosztownym przedsięwzięciem i czasami bardzo trudnym do wykonania ze względu na nieodpowiednie warunki drogowe.

Zwiększająca się liczba przewozów elektrowni wiatrowych powoduje, że wzrasta liczba przewoźników drogowych oferujących swoje usługi na tym rynku. Nierzadko konwoje realizowane przez różnych przewoźników podążają jeden za drugim w porze nocnej. Konieczne działania w zakresie dostosowania infrastruktury drogowej, dokonywane są przez każdego z przewoźników osobno i zdarza się, że brak koordynacji tych działań powoduje niepotrzebne koszty. Przykładowo, po przejściu konwoju przewoźnik jest zobowiązany usunąć wszelkie zmiany, których dokonał w celu dostosowania infrastruktury drogowej, a zaraz po nim przejeżdża kolejny konwój który ponownie wykonuje te same czynności dostosowawcze. Takie zdarzenia mają miejsce m.in. dlatego, że lokalizacja farm wiatrowych w pasie nadmorskim wymusza zbliżone trasy dojazdu od producentów sekcji w głębi lądu.

\subsection{TECHNOLOGIE PRZELADUNKU ELEMENTÓW ELEKTROWNI WIATROWYCH}

Jednym z liderów, jeśli chodzi o obsługę elementów farm wiatrowych w Polsce, jest Morska Agencja Gdynia, która zajmuje się przeładunkiem elementów turbin wiatrowych w portach, ich transportem morskim oraz lądowym.

Zadaniem MAG jest frachtowanie statków, które mają przywieźć do Polski elementy farm, następnie ich przeładunek i magazynowanie, czasami konserwacja oraz dystrybucja i transport do miejsca docelowej instalacji. Jak powiedział Michał Śmigielski, dyrektor ds. rozwoju biznesu MAG „urządzenia te trafiają do Polski $\mathrm{z}$ bardzo różnych stron świata. W 2014 r. śmigła trafiały do Polski również z USA, a w styczniu 2015 roku z Turcji”'. Gdy turbina znalazła się w porcie gdyńskim czy świnoujskim, zaczyna się cała skomplikowana logistyka przewiezienia jej transportem drogowym do miejsca przeznaczenia. Jak poinformował Damian Bednarz, prezes Bedmet Logistic, opolskiej firmy, która zajmuje się transportem ponadnormatywnym i ciężkim - każda turbina jest przewożona na 10-11 samochodach w zależności od producenta.

Typowa kompletna turbina składa się z: 5 sekcji rur przewożonych na osobnych pojazdach, często specjalnymi, modułowymi $z$ adapterami, w których rura stanowi element nośny, 3 śmigieł przewożonych na osobnych samochodach, długość transportowa dochodzi często do $60 \mathrm{~m}$, generatora - przewożonego na modułowym zestawie zagłębionym. Masa całkowita dochodzi często do $160 \mathrm{t}^{7}$. Proces

\footnotetext{
${ }^{6} \mathrm{http} / /$ www.nooteboomgroup.com/nootboom/pl/nasze_produkty/rodzaje_transportu/transport_ elektrowni_wiatrowych [18.02.2016].

${ }^{7}$ http://transportwiatrakow.pl/ [18.02.2016].
} 
przygotowania zajmuje przeważnie 3-6 miesięcy, na co składa się przede wszystkim czas niezbędny do uzyskania zezwoleń na przejazd, wykonanie ekspertyz obiektów mostowych, przebudowy i utwardzenia rond oraz dróg.

W celu prawidłowego przebiegu projektu, niezwykle ważna pozostaje komunikacja oraz koordynacja pomiędzy firmą zajmującą się obsługą portową a przewoźnikiem, w tym przypadku między MAG a Bedment Logistic.

Przykładem takiej współpracy było przewiezienie na liczącej $900 \mathrm{~km}$ trasie Gdynia - Zopowy, 11 kompletnych wież, każda składająca się z 10 elementów (5 sekcji wieży + 3 śmigieł + generatora + piasty), czyli łącznie 110 elementów. Najdłuższe zestawy ze śmigłami liczyły 49 m długości, a najcięższy zestaw z generatorem ważył 150 t. Przygotowania trwały 3 miesiące, w ciągu których wykonano m.in. 72 ekspertyzy obiektów mostowych, przebudowano 2 ronda oraz utwardzono wysepki rozdzielające pasy ruchu. Do transportu, który trwał 5 tygodni, użyto m.in. dwie specjalne naczepy modułowe $\mathrm{z}$ adapterami do wież wiatrowych.

\subsection{AlternATYWY TRANSPORTU ELEMENTÓW ELEKTROWNI WIATROWYCH}

Transport drogowy jest najpowszechniejszą technologią przewozu elementów siłowni wiatrowych w warunkach krajowych oraz europejskich. Wymaga on jednak dróg o odpowiednich parametrach, których w Polsce jest bardzo mało. $\mathrm{Z}$ reguły drogi są do tego celu zbyt wąskie, nie zawsze posiadają pobocze, są w złym stanie technicznym, a ruch kołowy posiada zbyt mały promień łuku. $\mathrm{Na}$ większości dróg krajowych mogą poruszać się ciągniki siodłowe z naczepami o masie całkowitej do $42 \mathrm{t}$, obciążeniu na pojedynczą oś do $10 \mathrm{t}$, długość pojazdu nie może przekroczyć $16,5 \mathrm{~m}$, wysokość $-4 \mathrm{~m}$, a szerokość $-2,55 \mathrm{~m}$. Wiele budowli infrastrukturalnych, zwłaszcza wybudowanych przed II wojną światową, posiada nieodpowiednie parametry techniczne, np. wiadukty o wysokości poniżej $4 \mathrm{~m}$. Inne utrudnienie stanowić mogą napowietrzne linie energetyczne i telekomunikacyjne oraz nieodpowiedni stopień nachylenia drogi. Droga asfaltowa nie może posiadać nachylenia większego aniżeli $12 \%$, a żwirowa - 6\%, ponieważ większe nachylenie może spowodować zerwanie mocowania ładunku lub jego zsunięcie, co eliminuje przewóz w warunkach górskich ${ }^{8}$.

W przypadku przewozu ładunków nienormatywnych koleją, nie istnieje tak wiele ograniczeń jak dla transportu drogowego. Ciężar elementów nie stanowi problemu, ze względu na fakt, iż granice obciążenia wagonów często dochodzą nawet do 100 t, kłopot stanowić mogą jednak ich wymiary. Według skrajni taboru obowiązującej w Polsce (linii zamkniętej, której nie może przekroczyć element wagonu ani umieszczony na nim ładunek), dopuszczalna wysokość wagonu z ładunkiem nie może przekroczyć $4,85 \mathrm{~m}$. W przypadku niektórych elementów

${ }^{8}$ I. Kotowska, G. Barzyk, Transport drogowy elementów elektrowni wiatrowych w warunkach polskich, „Czysta Energia”, nr 07/08, 2003, s. 21. 
siłowni wiatrowych jest to wielkość niewystarczająca, np. dla sekcji wieży o średnicy ok. $3 \mathrm{~m}$ (wznios platformy z obniżoną podłogą przekracza $1 \mathrm{~m}$ ). Długość platform cztero- i sześcioosiowych wynosi 15-19 m. Ładowanie elementów o długości powyżej $25 \mathrm{~m}$ wymaga umieszczenia na platformach z ławą przekrętną, co stanowi kolejne utrudnienie. Istnieje jednak możliwość przewozu ładunków o przekroczonej skrajni taboru jako przesyłek nadzwyczajnych (szczegółowe warunki reguluje Regulamin Przewozu Przesyłek Towarowych PKP CARGO S.A.) $)^{9}$. Do przewozu ładunków ciężkich i wielkogabarytowych stosunkowo często wykorzystywany jest transport śródlądowy. Największą zaletą żeglugi śródlądowej jest masowość przewozu. Ten typ transportu charakteryzują mniejsze ograniczenia pod względem wielkości i masy przesyłki aniżeli transport samochodowy i kolejowy. Żegluga śródlądowa posiada duży stopień bezpieczeństwa i bezkolizyjności przewozów. Ta technologia przewozu charakteryzuje się jednak małą dostępnością żeglugową, wysokim współczynnikiem wydłużenia i małą prędkością techniczną. Głównym ograniczeniem w Polsce jest wysokość mostów na szlakach żeglugowych, często o wysokości poniżej $4 \mathrm{~m}$. Istotnym zagadnieniem jest także wyposażenie portów - głównie w żurawie przeładunkowe o niewielkim udźwigu, w związku z tym niezbędnym jest wypożyczenie odpowiedniego żurawia samojezdnego.

\section{Podsumowanie}

Obecnie w Polsce istnieją trzy główne możliwości przewozu elementów elektrowni wiatrowych: transport drogowy (z wykorzystaniem ciągników siodłowych), kolej oraz żegluga śródlądowa. W powszechnym użyciu pozostaje tylko jedna z nich - transport samochodami ciężarowymi. Jest to opcja najpowszechniej dostępna i umożliwiająca dowiezienie elementów siłowni prawie w każde miejsce w kraju.

Strategia rozwoju energetyki wiatrowej w Polsce musi być powiązana ze strategią rozwoju transportu nienormatywnego turbin wiatrowych. W tym, musi zawierać procedury tworzenia nienormatywnych korytarzy transportowych. Korytarze powinny być coraz lepiej dostosowywane infrastrukturalnie do potrzeb przewozu długich i ciężkich ładunków. Co więcej, konieczna jest zmiana procedury korzystania $\mathrm{z}$ tych korytarzy.

Projektowanie i realizacja transportu każdego ładunku jest wielopoziomowym procesem logistycznym mającym na celu przygotowanie ładunku, środka transportu, jak również infrastruktury transportowej do bezpiecznego przemieszczenia ładunku na określonym odcinku trasy. Transport stanowi jeden z podstawowych elementów w działalności logistycznej. Współczesne procesy transportowe

${ }^{9}$ I. Kotowska, G. Barzyk, Alternatywne możliwości transportu elementów elektrowni wiatrowych w warunkach Polski, IX Forum OZE, Warszawa 2004, s. 6. 
charakteryzują się znaczną spójnością i będąc zintegrowane ze sobą stanowią podstawę funkcjonowania krajowych, jak i międzynarodowych łańcuchów dostaw. Funkcjonowanie transportu jako istotnego ogniwa usług logistycznych jest ściśle uzależnione od istniejącej infrastruktury. Infrastruktura transportu determinuje więc możliwości przewozu i koszty transportu, a tym samym wpływa na koszty i jakość usług logistycznych.

\section{BibLiOgRAFia}

Kotowska I., Barzyk G., Alternatywne możliwości transportu elementów elektrowni wiatrowych $w$ warunkach Polski, IX Forum OZE, Warszawa 2004.

Kotowska I., Barzyk G., Transport drogowy elementów elektrowni wiatrowych w warunkach polskich, „Czysta Energia”, nr 07/08, 2003.

Petrakopoulou F., Tsatsaronis G., Morosuk T., Paitazoglou C., Environmental evaluation of a power plant using conventional and advanced energy based methods, „Energy”, Vol. 45, No. 1, 2012.

Rydzkowski W., Wojewódzka-Król K., Transport, PWN, Warszawa 2005.

Wiśnicki B., Kujawski A., Breitsprecher M., Poprawa efektywności transportu nienormatywnego obslugujacego farmy wiatrowe $w$ Polsce, TRANSCOMP - XIV International Conference Computer Systems Aided Science, Industry and Transport, Zakopane 2010.

Dyrektywa Parlamentu Europejskiego i Rady 2009/28/WE z dnia 23 kwietnia 2009 roku w sprawie promowania stosowania energii ze źródeł odnawialnych.

Prognoza zapotrzebowania na paliwo i energię do 2030 r., Załącznik 2. do „Polityki energetycznej Polski do 2030 roku", Ministerstwo Gospodarki, 2009.

www.rynek-energii-elektrycznej.cire.pl.

www.solidworks.com.

www.psew.pl.

www.ure.gov.pl. 


\author{
Aleksander Wojtowicz \\ Uniwersytet Łódzki \\ Katedra Logistyki \\ ul. Matejki 22/26, 90-237 Łódź
}

\title{
13. Subtropolis jako alternatywa dla tradycyjnych metod składowania zapasów
}

\section{WPROWADZENIE}

Magazynowanie to jeden z kluczowych procesów logistycznych w łańcuchu dostaw. Obecnie możemy zaobserwować rosnące zapotrzebowanie na przestrzeń logistyczno-magazynową, które jest napędzane przez nowe trendy w handlu. Koncentracja powierzchni magazynowych na danym obszarze, zachęca potencjalnych inwestorów do lokalizacji zakładów produkcyjnych w ich pobliżu. Magazynowanie nie ogranicza się jedynie do procesu składowania zapasów. Centra logistyczne umożliwiają różnym niezależnym przedsiębiorstwom wykonywanie szeregu usług dodatkowych, w związku z magazynowaniem oraz przemieszczaniem towarów. Dynamika przyrostu nowych powierzchni magazynowych jest jednak zbyt niska, by sprostać rosnącemu zapotrzebowaniu, co może skutkować wzrostem cen obecnie wynajmowanych powierzchni. Z punktu widzenia przedsiębiorstwa, ceny ziemi i wynajmu są elementami istotnie wpływającymi na całkowity koszt magazynowania. Adaptacja istniejących budowli również wymaga znaczących nakładów finansowych. Dążąc do obniżenia kosztów eksploatacyjnych i nakładów finansowych poniesionych np. na konstruk-cję nowego magazynu, firmy starają się poszukiwać nowych, alternatywnych metod dla składowania zapasów. Celem rozdziału jest przedstawienie podziemnego kompleksu SubTropolis, którego właścicielem jest HuntMidwestEneterprises S.A. jako interesującej alternatywy dla tradycyjnych metod składowania zapasów.

\subsection{SUBTROPOLIS - KLUCZOWE INFORMACJE O KOMPLEKSIE BIZNESOWYM}

SubTropolis jest podziemnym kompleksem biznesowym zlokalizowanym na głębokości ok. 49 m w starej kopalni wapienia na przedmieściach Kansas City w stanie Missouri, USA. Początek działalności SubTropolis można datować na rok 1964. To właśnie wtedy zostały wynajęte pierwsze podziemne powierzchnie m.in. firmie Ford. Kompleks obejmuje ponad $5 \mathrm{mln} \mathrm{m}^{2}$ powierzchni użytkowej pod ziemią, jak i na powierzchni, co zapewnia maksymalne wykorzystanie pionowej przestrzeni magazynowej. SubTroplis to nie tylko podziemne powierzchnie 
przeznaczone do magazynowania towarów w wąskim znaczeniu tego określenia. $\mathrm{Na}$ terenie obiektu działa ponad 50 międzynarodowych, krajowych, regionalnych oraz lokalnych przedsiębiorstw, których profil działalności jest wysoce zróżnicowany. Operatorzy wykorzystują podziemne przestrzenie do prowadzenia szeregu działań związanych z dystrybucją (FedEx, UPS), przechowywaniem danych, lekką produkcją, przechowywaniem żywności, jak również montażem samochodów (Automotive Alley ${ }^{1}$ ). Są to priorytetowe usługi świadczone przez SubTropolis.

Wolne przestrzenie utworzone przez górnictwo wapienne zostały w odpowiedni sposób przystosowane dla celów logistycznych. Wydrążone wapienne komory mają wymiary 4,9 m wysokości i ok. 12 m szerokości. Komory przedzielone są wapiennymi filarami, których grubość dochodzi do 7,6 m. Na skutek eksploatacji podziemnej przestrzeni powstało ponad 550 tys. $\mathrm{m}^{2}$ przestrzeni użytkowej, której stabilność zapewnia ponad 10 tys. wapiennych filarów. $\mathrm{Na}$ teren SubTropolis można dostać się za pomocą 57 bram. Odpowiednią komunikację pomiędzy poszczególnymi częściami podziemnego kompleksu zapewnia ponad $11 \mathrm{~km}$ utwardzonych i oświetlonych dróg oraz $13 \mathrm{~km}$ torów kolejowych ${ }^{2}$. Podziemna sieć drogowo - kolejowa jest stale rozbudowywana wraz z powiększaniem przestrzeni użytkowej. Ograniczenia przestrzenne nie pozwalają jednak pojazdom na zawracanie w przypadku wybrania niewłaściwej trasy. SubTropolis jest przystosowane do obsługi samochodów ciężarowych. Ponad 400 doków dla ciężarówek jest w stanie zapewnić obsługę ok. 500 naczep i ciągników siodłowych dziennie. Na terenie obiektu znajduje się również ponad 1,6 tys. miejsc parkingowych. W kompleksie biznesowym jest zatrudnionych ok. 1600 pracowników.

SubTropolis oferuje szeroki wachlarz powierzchni użytkowej. Wydrążone komory zostały podzielone na sekcje. Są one zróżnicowane pod względem powierzchni, wyposażenia oraz dostępu do wewnętrznej sieci drogowo - kolejowej. Dzięki temu każdy kontrahent może wynająć powierzchnię odpowiadającą jego potrzebom. Rysunek 1 przedstawia przestrzeń przeznaczoną pod dzierżawę oznaczoną symbolem 62G. Jej powierzchnia wynosi ok. $1200 \mathrm{~m}^{2}$. Posiada ona $1 \mathrm{dok}$ z wysokimi drzwiami do obsługi naczep i ciągników siodłowych oraz dostęp do wewnętrznej sieci kolejowej. Oferowana powierzchnia jest w pełni zelektryfikowana, jak również wyposażona w system spryskiwaczy zapewniających bezpieczeństwo przeciwpożarowe.

W podziemnych komorach panują stałe warunki klimatyczne. Temperatura przez cały rok utrzymuje się w przedziale $18-21^{\circ} \mathrm{C}$. Rozbudowana sieć szybów wentylacyjnych pozwala również kontrolować poziom wilgotności powietrza. Wszystkie ściany oraz sufit zostały pokryte białą farbą, ponieważ brak dostępu do

\footnotetext{
${ }^{1}$ www.edckc.com/portfolio/automotive-alley-hunt-midwest-subtropolis [14.01.2016].

${ }^{2}$ Ż. Bodusińska, M. Fluder, M. Król, A. Lorenc, D. Wnęk, Przyszłość składowania zapasów na przykładzie największego na świecie podziemnego magazynu SubTropolis, „Logistyka”, nr 4, 2013, s. 37.
} 
13. SUbTROPOlis JAKO ALTERNATYWA DLA TRADYCYJNYCH METOD SKŁADOWANIA ZAPASÓW...

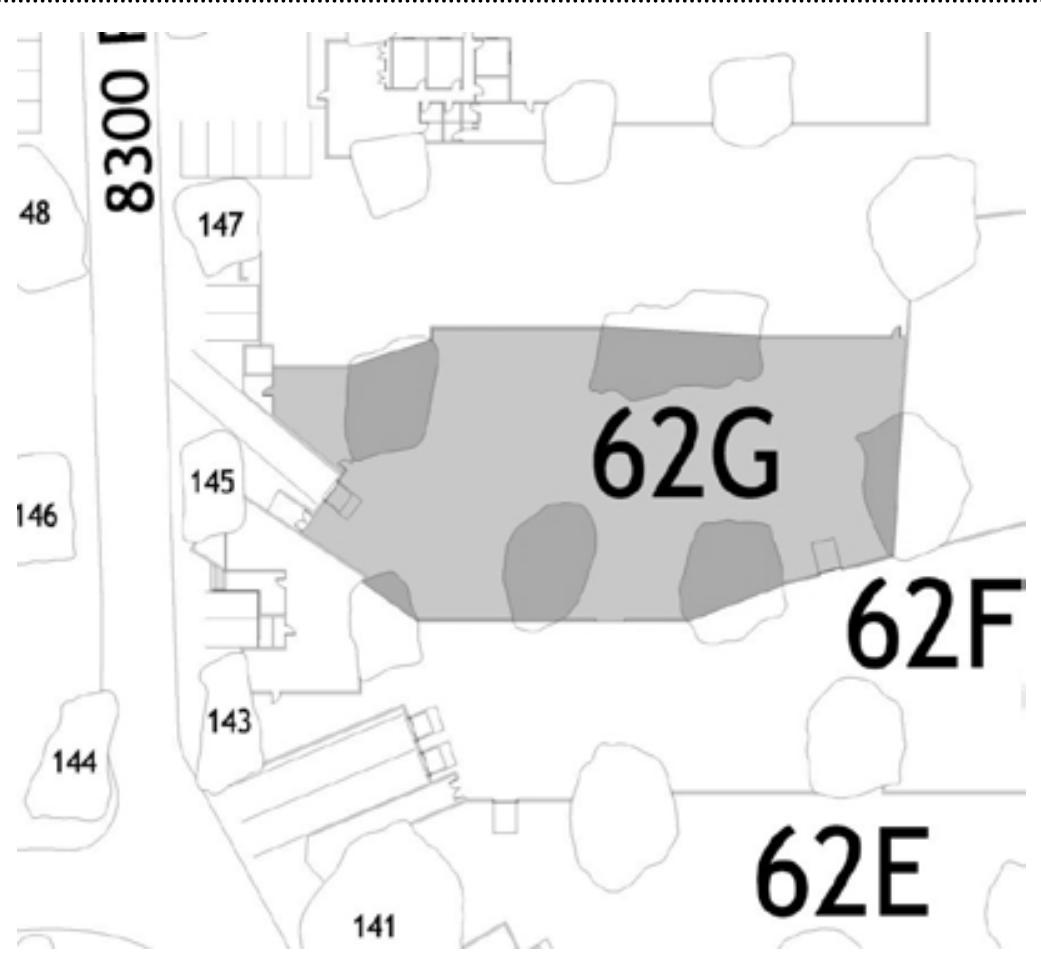

Rysunek 1. Przykładowa powierzchnia przeznaczona pod dzierżawę

Źródło: materiały informacyjne udostępnione przez firmę HuntMidwestEneterprises S.A.

naturalnego światła może być czynnikiem negatywnie wpływającym na komfort pracy pracowników. Niewątpliwie zaletą podziemnego kompleksu jest jego odporność na zmienne zewnętrzne warunki pogodowe. SubTropolis jest od nich całkowicie niezależne. Wszystko to sprawia, iż pod ziemią panują dogodne warunki do pracy. SubTropolis jest największym na świecie podziemnym kompleksem biznesowym. Ze względu na swoje usytuowanie często określany jest mianem przestrzeni magazynowej posiadającej największy „zielony dach”.

\subsection{CZYNNIKI WARUNKUJĄCE SUKCES PODZIEMNEGO KOMPLEKSU SubTropolis}

Podziemny kompleks SubTropolis posiada szereg zalet, które pozwalają mu być istotną alternatywą dla tradycyjnych magazynów, jak i centrów logistycznych na rynku amerykańskim. Należy do nich zaliczyć: dogodną lokalizację, bezpieczeństwo, wysoce konkurencyjne koszty eksploatacyjne w porównaniu $\mathrm{z}$ tradycyjnymi budowlami magazynowymi. 
Lokalizacja każdego obiektu logistycznego powinna podlegać szczegółowym badaniom zarówno obliczeniowym, jak i logistycznym. Szczególnie takie obiekty, jak centra logistyczne, które zajmują bardzo duże obszary powierzchniowe i wymagają bogato wyposażonego zaplecza wraz z infrastrukturą drogową, powinny być zlokalizowane $\mathrm{w}$ bardzo przemyślany sposób. Kansas City znajduje się w centralnej części Stanów Zjednoczonych. Jest połączone z pozostałą częścią kraju rozległą siecią autostrad i dróg ekspresowych. Wszystko to sprawia, iż lokalizacja SubTropolis spełnia oczekiwania potencjalnych kontrahentów względem dostarczenia towarów do różnych części USA w możliwie jak najkrótszym czasie.

Czas transportu drogowego do największych miast takich, jak Nowy Jork czy Los Angeles wynosi od 2 do $3 \mathrm{dni}$, co przedstawiono na rysunku 2. Co więcej, sam kompleks położony jest jedynie w odległości $10 \mathrm{~min}$. drogi samochodem od ścisłego centrum Kansas, jak również 20 min. od międzynarodowego portu lotniczego w Kansas City.

Ze względu na funkcje, jakie pełni SubTropolis, konieczne jest zapewnienie odpowiednich warunków pozwalających na bezpieczne przechowywanie różnorodnych dóbr materialnych. Składowanie towarów w bezpieczny sposób pozwala

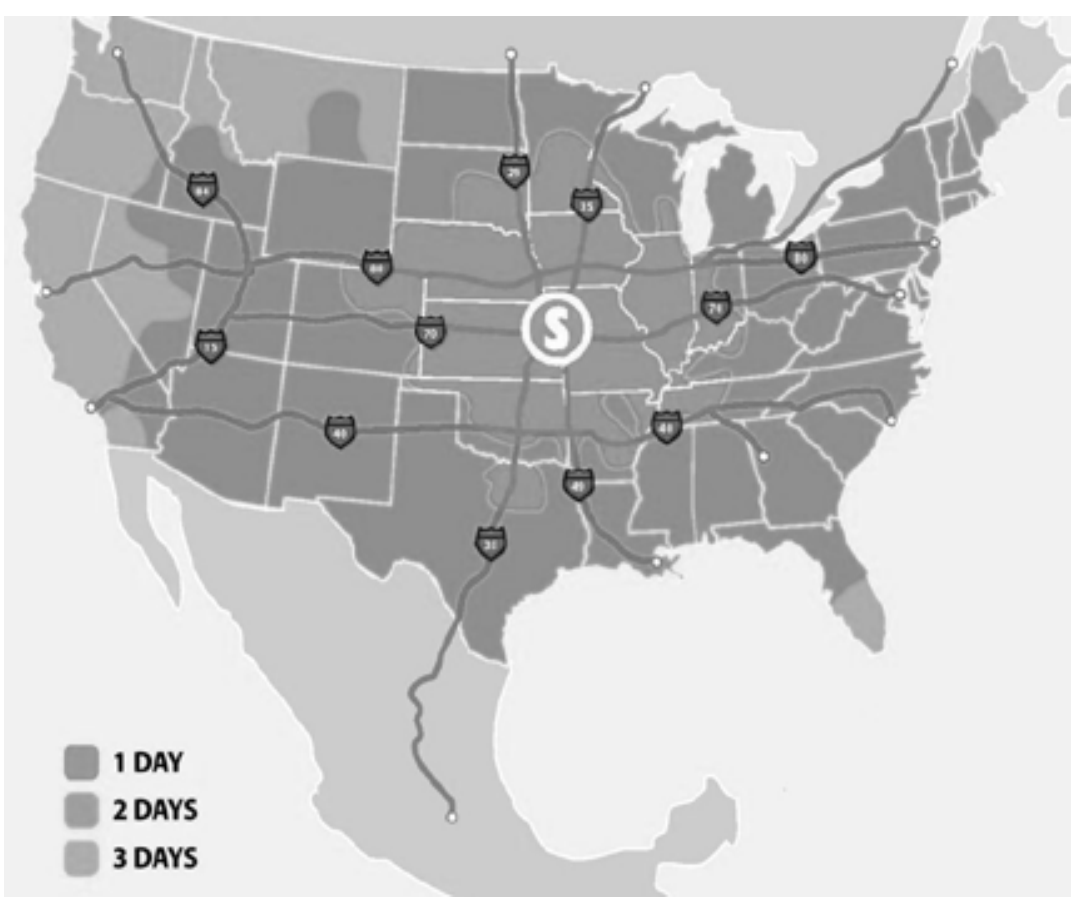

Rysunek 2. Czas potrzebny na dowóz transportem drogowym z SubTropolis względem pozostałych miejsc w USA

Źródło: Ibidem. 
uniknąć zagrożenia dla osób postronnych lub innych niepożądanych następstw magazynowania. Istotne jest również zapewnienie dostatecznego bezpieczeństwa składowanych dóbr przed kradzieżą. Lokalizacja obiektu w byłej kopalni wapienia zapewnia stabilność konstrukcyjną podziemnej budowli. Wapienne filary mające 6 razy większą wytrzymałość niż konstrukcje wykonane z betonu, w naturalny sposób chronią magazyny przed ewentualnymi klęskami żywiołowymi. Firmy korzystające z usług SubTropolis nie muszą dodatkowo ubezpieczać swoich towarów. Obiekt znajduje się pod stałą kontrolą uzbrojonych służb ochrony i jest monitorowany całą dobę. Dodatkowo bezpieczeństwo zapewniają:

- skanery biometryczne,

- systemy dostępu oparte o specjalnie wydawane karty elektroniczne,

- ogrodzenie zewnętrznego terenu, na którym znajduje się podziemne centrum,

- fizyczne bariery wewnątrz obiektu,

- punkty kontroli i inspekcji pojazdów wjeżdżających na teren obiektu³.

W tradycyjnym przedsiębiorstwie, posiadanie lub dzierżawa powierzchni magazynowej są związane z ponoszeniem szeregu kosztów dotyczących utrzymania budynku magazynowego oraz jego infrastruktury. Koszty utrzymania budynku wynikają z konieczności jego ogrzania, oświetlenia, jak również funkcjonowania niezbędnych urządzeń technicznych w jego wnętrzu. Zgodnie z obowiązującymi przepisami należy również zadbać o ochronę przeciwpożarową. W porównaniu do tradycyjnych obie- któw naziemnych przeznaczonych do składowania, SubTropolis zużywa o $85 \%$ mniej energii potrzebnej do chłodzenia bądź ogrzewania ${ }^{4}$. Wykorzystanie energii wiatrowej zapewnia samowystarczalność energetyczną przedsiębiorstw operujących na terenie SubTropolis. Proekologiczna wapienna budowla zapewnia stałą temperaturę i wilgotność powietrza, niezależnie od pory roku. Średnie koszty eksploatacyjne związane ze zużyciem energii są przeciętnie o 50-70\% mniejsze, co generuje znaczne oszczędności ${ }^{5}$. Niskie koszty utrzymania budowli wynikają również z braku większej konieczności dodatkowego przystosowania istniejących przestrzeni. Średni koszt wynajmu podziemnych przestrzeni magazynu wynosi ok. 99 centów dziennie za $\mathrm{m}^{2}$ powierzchni ${ }^{6}$. Jest on o $30-50 \%$ niższy niż koszt dzierżawy naziemnych magazynów.

\subsection{ZASAda ZRóWnOWAżonego ROZWOJU NA PRZYKŁAdZIE SUBTropolis}

Obecnie coraz więcej przedsiębiorstw dobrowolnie uwzględnia w swojej polityce działania, których celem jest osiągnięcie równowagi między efektywnością, a interesem społecznym. Poprawa relacji ze społecznością i władzami lokalnymi

\footnotetext{
${ }^{3}$ www.huntmidwest.com/subtropolis-industrial-space-for-lease [15.01.2016].

${ }^{4}$ Ż. Bodusińska, M. Fluder, M. Król, A. Lorenc, D. Wnęk, op. cit., s. 37.

${ }^{5}$ www.huntmidwest.com/subtropolis-industrial-space-for-lease [15.01.2016].

${ }^{6}$ Ż. Bodusińska, M. Fluder, M. Król, A. Lorenc, D. Wnęk, op. cit., s. 37.
} 
pozwala pozyskać przychylność mieszkańców, jak również zdobyć zaufanie władz samorządowych. Wprowadzenie zasad odpowiedzialnego biznesu jest jednym $\mathrm{z}$ atutów, który może zapewnić firmie przewagę konkurencyjną w dłuższym okresie. Funkcjonowaniu podziemnego kompleksu SubTropolis przyświeca 5 zasad. Obowiązują one samą firmę, jak i najemców powierzchni magazynowych. Możemy do nich zaliczyć:

- zobowiązanie do odzysku surowców i materiałów oraz korzystanie z produktów pochodzących z recyklingu,

- ochronę zasobów naturalnych i zmniejszanie zużycia energii,

- poświadczenie przestrzegania wszelkich przepisów ochrony środowiska,

- zachęcanie kooperantów do proekologicznej postawy,

- wymiana wszystkich żarówek na energooszczędne $e^{7}$.

Wychodząc naprzeciw dążeniom mającym na celu zmniejszenie zużycia energii i dbałość o dobry wizerunek w zakresie odpowiedzialności ekologicznej, SubTropolis uzyskało certyfikat Energy Star. Wyższa efektywność energetyczna produktów zgodnych ze standardem Energy Star gwarantuje efektywniejsze wykorzystanie energii elektrycznej. Efektywne wykorzystywanie energii elektrycznej powoduje wymierne korzyści finansowe w postaci niższych rachunków.

Istotną kwestią lokalizacji SubTropolis w pobliżu dużego miasta są konsekwencje ekonomiczno-społeczne dla funkcjonowania aglomeracji. Lokalizacja centrów logistycznych w danym regionie przyczynia się do przyciągania nowych inwestycji, szczególnie dotyczących działalności produkcyjnej i handlowej, wymagających obsługi logistycznej. Centra usług logistycznych, właściwie zlokalizowane w obszarze aglomeracji miejskich, wywołują zwykle pozytywny efekt odciążenia dzielnic mieszkaniowych od ruchu ciężkich środków transportu. Obecnie możemy zaobserwować stopniowo rosnący trend na rzecz odzyskiwania zajętych terenów śródmiejskich pod działalność gospodarczą na inne cele. Lokalizacja SubTropolis w byłej kopalni wapienia idealnie wpisuje się w powyższą praktykę. Rozwiązanie to nie wpływa negatywnie na krajobraz miasta. Duży kompleks logistyczny, jakim jest SubTropolis, w harmonijny sposób współistnieje z aglomeracją Kansas City.

\section{Podsumowanie}

Podziemny magazyn SubTropolis spełnia szereg warunków predysponujących go do miana centrum logistycznego. Jego przestrzenie służą nie tylko do magazynowania towarów. Przedsiębiorstwa działające na terenie kompleksu zajmują się również dystrybucją, a nawet lekką produkcją. Warunki klimatyczne panujące wewnątrz obiektu są idealne do przechowywania żywności lub wrażliwych na działanie wilgoci mikrofilmów. Wapienna konstrukcja zapewnia bezpieczeństwo

${ }^{7}$ Ibidem, s. 38 . 
zgromadzonym we wnętrzu materiałom. Pomimo, iż maksymalna eksploatacja podziemnych przestrzeni jest ograniczona, SubTropolis to wciąż rozwiązanie rozwojowe. Co roku następuje zwiększenie powierzchni magazynowej o ok. 13 tys. $\mathrm{m}^{2}$. Sprzyjające warunki naturalne pozwalają użytkownikom kompleksu na znaczące zmniejszenie kosztów związanych z energią.

Podziemne magazyny są rozwiązaniem przyszłościowym. Nie oznacza to jednak, iż w najbliższym czasie liczba podziemnych kompleksów magazynowych znacząco wzrośnie. Sukces powyższego przedsięwzięcia zależy od wielu czynników. Rozwiązanie zastosowane w Kansas City bazuje na wykorzystaniu lokalnego, naturalnego potencjału w postaci kopalni wapienia. Przeniesienie rozwiązań zastosowanych w SubTropolis na grunt innej aglomeracji, nie posiadającej sprzyjających czynników naturalnych, będzie najprawdopodobniej wysoko nieopłacalne. Skala kosztów poniesionych na budowę podziemnego kompleksu od podstaw byłaby ogromna. Dlatego na magazyny podziemne, powinny być adaptowane wyrobiska złóż naturalnych, które jak wapień charakteryzują się wysoką wytrzymałością. Nie generuje to dodatkowych kosztów materiałów budowlanych, które trzeba byłoby ponieść w związku z budową naziemnego kompleksu. Operator podziemnego kompleksu musi jedynie zadbać o odpowiednią sieć dróg i system wentylacji. Warto wspomnieć o podobnym rozwiązaniu przeniesionym na grunt miejski w Toronto. PATH jest podziemnym systemem ulic i przejść o łącznej długości $30 \mathrm{~km}$, które rocznie przemierza ok. $55 \mathrm{mln}$ osób.

\section{Bibliografia}

Bodusińska Ż, Fluder M., Król M., Lorenc A., Wnęk D., Przyszłość składowania zapasów na przykładzie największego na świecie podziemnego magazynu SubTropolis, „Logistyka”, nr 4, 2013. www.huntmidwest.com/subtropolis-industrial-space-for-lease [15.01.2016]. www.edckc.com/portfolio/automotive-alley-hunt-midwest-subtropolis [15.01.2016]. www.bloomberg.com/news/features/2015-02-04/welcome-to-subtropolis-the-business-complex -buried-under-kansas-city [15.01.2016].

Materiały informacyjne udostępnione przez firmę HuntMidwestEneterprises S.A. 

Natalia Wójcik

Akademia Morska w Gdyni

Wydział Przedsiębiorczości i Towaroznawstwa

ul. Morska 81-87, 81-225 Gdynia

\section{Zastosowanie modeli biznesowych uwzględniających e-commerce}

\section{WPROWADZENIE}

E-commerce jest jedną z dziedzin, która bez względu na koniunkturę na światowych rynkach stale się rozwija. W procesach, jakie zachodzą na współczesnym rynku, udział bierze szereg podmiotów, współpracujących ze sobą na różnych płaszczyznach. Mowa tu o różnorodnych partnerach handlowych, dostawcach i klientach. Do tej grupy zalicza się również dostawców usług, którzy również uczestniczą w transakcjach przeprowadzanych drogą elektroniczną ${ }^{1}$. Celem niniejszego rozdziału jest analiza modeli biznesowych w e-commerce. Rozdział przedstawia istotę modeli e-biznesu oraz jego formy.

\subsection{MODELE E-BIZNESU}

W dobie globalizacji i dynamicznych zmian na rynku kluczowe cechy modeli e-biznesu to ich innowacyjność, elastyczność, otwartość i generowanie wartości dla interesariuszy. Usprawnienia handlu elektronicznego, takie jak skrócenie łańcucha dostaw w celu zwiększenia efektywności i usprawnienia dystrybucji, skrócenie czasu dostawy towarów, zmniejszenie kosztów zapasów magazynowych prowadzą do obniżenia ceny produktu. Handel elektroniczny zmierza do poprawy satysfakcji klientów przez dostarczenie klientom indywidualnym i firmom rozwiązań spełniających ich oczekiwania. Uczestnikami procesów e-commerce w szczególności są kontrahenci bezpośrednio w nie zaangażowani, czyli klienci i dostawcy.

Modeli e-biznesu jest wiele, jednakże tutaj zwrócona zostanie szczególna uwaga na cztery $\mathrm{z}$ nich: B2B (biznes-biznes), B2A (biznes-administracja), B2C (biznes-klient), C2A (klient-administracja). Poszczególne litery oznaczają:

- A - określa różnorodne instytucje o charakterze administracyjnym i rządowym,

- B - oznacza słowo pochodzące $\mathrm{z}$ ang. business, jest to instytucja, firma czy nawet przedsiębiorstwo, które jest nastawione na osiągnięcie jak największego zysku,

${ }^{1}$ B. Gregor, M. Stawiszyński, E-Commerce, Oficyna Wydawnicza BRANTA, Łódź 2002, s. 10-32. 
- C - oznacza słowo pochodzące $\mathrm{z}$ ang. customer lub client, jest to osoba o charakterze prywatnym, która jest klientem przedsiębiorstwa bądź petentem w urzędach administracji publicznej.

Poniżej przedstawione zostaną bardziej szczegółowe opisy wymienionych modeli biznesowych.

Platforma wirtualnego rynku elektronicznego B2B (biznes-biznes) jest świetnym i bardzo popularnym narzędziem używanym przez marketing do aktywizacji takich działań, jak wymiana gospodarcza za pośrednictwem Internetu pośród wielu różnorodnych podmiotów gospodarczych. B2B jest skrótem od słów business to business, którymi określa się transakcje zachodzące pomiędzy różnorodnymi firmami czy przedsiębiorstwami. W historii istnienia handlu zawsze można było spotkać się z firmami lub osobami prywatnymi, które świadczyły innym usługi, których celem głównym była szeroko pojęta pomoc w realizacji profilu swojej działalności czy w kontaktach z innymi kontrahentami. Współcześnie Internet kształtuje zupełnie nowe zachowania wraz z jego rozwojem ukształtował się B2B. Sektor ten ma bardzo dużo do zaoferowania firmom o różnej wielkości i charakterze $e^{2}$.

Definicja tego modelu biznesowego, jaką można znaleźć w różnorodnych publikacjach i artykułach, brzmi następująco: korzystanie z szeregu środków o charakterze elektronicznym, służących do zawierania różnorodnych transakcji pomiędzy firmami. Podstawowym celem, jaki przyświeca modelowi B2B, jest zapewnienie i dostarczenie realnych oszczędności oraz zysków, które w zamierzeniu przedsiębiorcy mają usprawnić wiele procesów, jakie zachodzą w przedsiębiorstwie. Niezbędne jest do tego celu posiadanie odpowiednio przygotowanej infrastruktury złożonego rynku biznesu elektronicznego oraz znajomość rynków elektronicznych ${ }^{3}$. W tym właśnie momencie na scenę wkraczają firmy z sektora B2B, które są w stanie zaoferować osobom tym zainteresowanym, mnogość usług i produktów, które pozwolą im łatwo i bezproblemowo wejść w świat innowacyjnych metod prowadzenia działalności gospodarczej.

Business to business daje firmie możliwość wykorzystania szerokiego wachlarza możliwości oferowanych przez Internet. Są one obecnie ogromnym wsparciem dla dobrej komunikacji, a także handlu pomiędzy różnymi firmami. Stąd też tak ważne są rynki elektroniczne, na których skupia się właśnie działalność tego typu. Te zaś o charakterze stricte elektronicznym podzielić można na dwie główne kategorie, mianowicie: rynki horyzontalne i rynki wertykalne. Pierwszy rodzaj skupia się na bardzo szerokim wachlarzu usług i towarów pochodzących $\mathrm{z}$ wielu branż. Drugi natomiast opiera się na rynkach wyspecjalizowanych, które zajmują się w swojej działalności bardzo wąskimi i nieraz charakterystycznymi dziedzinami.

${ }^{2}$ Ibidem.

${ }^{3}$ P. Sztompka, Socjologia zmian społecznych, Wydawnictwo Znak, Kraków 2010, s. 79. 
Model B2A (biznes-administracja) znajduje się nadal w bardzo wczesnym stadium swojego rozwoju. Działania, jakie podejmuje, są skierowane głównie w stronę odpowiedzialną za organizację sektora publicznego. B2A w głównej mierze skupia swoje działania na zaangażowaniu technik elektronicznych przesyłania większości informacji pomiędzy dwoma sektorami, mianowicie: przedsiębiorstwem i administracją publiczną. Usługi, jakie obejmuje swoim zakresem model B2A, są niezwykle różnorodne, dotyczą one takich obszarów działalności, jak4:

- kwestie podatkowe,

- szeroko pojęte bezpieczeństwo socjalne,

- zagadnienia związane z zatrudnieniem i pracą w ogóle,

- korzystanie z baz danych i różnorodnych rejestrów,

- kwestie związane $\mathrm{z}$ handlem, płatnościami i innymi transakcjami związanymi $\mathrm{z}$ przetargami w systemie online.

Obecnie analitycy rynku e-commerce przewidują dosyć dynamiczny wzrost tego modelu. Sytuacja taka ma być spowodowana przede wszystkim różnymi działaniami promocyjnymi skierowanymi szczególnie do sektora administracyjnego. Mowa tu głównie o najnowszych osiągnięciach, jakie pojawiają się na rynku $\mathrm{w}$ kwestiach związanych $\mathrm{z}$ rozwojem elektronicznego rządu tzw. e-government oraz e-państwa.

Jedną z popularniejszych form B2A są systemy zajmujące się sprawozdawczością elektroniczną, których głównym zadaniem jest usprawnienie wymiany różnorodnych dokumentów, np. sprawozdań finansowych, bilansów różnego typu oraz innych ważnych i potrzebnych informacji, pomiędzy placówkami sektora administracyjnego, takimi jak: ZUS, urzędy statystyczne i skarbowe, a przedsiębiorstwami.

Model B2C (biznes-klient) to model biznesu opierający swą działalność o instrumenty elektroniczne, służące do przeprowadzania transakcji między przedsiębiorcami a konsumentem. Najważniejszym celem B2C oprócz pozyskiwania nowych klientów i sprzedaży jest tworzenie relacji z obecnymi klientami.

B2C ma zastosowanie dla różnych form działalności przedsiębiorczej, a wprowadzanie oferty na rynek można rozpocząć na każdym poziomie: od prostej $\mathrm{w}$ obsłudze strony internetowej do wielofunkcyjnego systemu transakcji internetowych, a także udziału w elektronicznych giełdach. Mało rozbudowana forma portalu B2C może posiadać ofertę towarów oraz funkcję składania i realizacji zamówienia za pośrednictwem różnych urządzeń, np. telefonu, e-maila. Do systemu można dołączyć funkcje samodzielnego dokonania zakupu i realizacji płatności on-line przez klienta 5 .

${ }^{4}$ J. Maciejewski, M. Salak, Społeczeństwo informacyjne a współczesne technologie teleinformatyczne, „Zeszyty Naukowe Wyższej Szkoły Zarządzania i Prawa w Warszawie”, nr 2, Warszawa 2004, s. 119.

${ }^{5}$ A. Charlesworth, Key concepts in e-commerce, Palgrave Macmillan, 2007, s. 15. 
Działalność w segmencie B2C jest silnie nakierowana na klienta. A. Banacewicz-Miazga podaje prawidłowość, według której utrzymanie dotychczasowego klienta jest 5-krotnie tańsze niż pozyskanie nowego. Jest to związane z dużą przejrzystością ofert internetowych oraz krótkim czasem potrzebnym do przejrzenia oferty konkurencji ${ }^{6}$. Firmy internetowe B2C starają się dlatego wykształcić więź łączącą je z klientem. W tym celu tworzone są programy lojalnościowe, kluby konsumenckie, a nawet programy angażujące klientów w opracowywanie nowych projektów ${ }^{7}$.

Model biznesowy oznaczony symbolem C2A (klient-administracja) określa relację, jaka występuje pomiędzy petentami, a placówkami administracji rządowej. Głównym jego zadaniem jest możliwość zgłoszenia się obywatela do rzeczonych urzędów w sprawie związanej z ważnymi dla niego kwestiami poprzez kontakt elektroniczny. Przykłady działań, jakie obejmuje C2A, to:

- złożenie wniosku o wydanie dokumentów takich, jak np.: dowód osobisty, prawo jazdy, paszport,

- wysłanie formularza PIT poprzez e-mail bądź formularz elektroniczny,

- składanie różnych innych wniosków zapotrzebowania na konkretne druki czy dokumenty,

- korzystanie z serwisów www konkretnych urzędów.

Najpopularniejszymi formami w działalności e-commerce są aukcje internetowe, serwisy ogłoszeniowe, sklepy internetowe różnego typu, wirtualne giełdy, a także inne formy handlu elektronicznego ${ }^{8}$. Wszystko to staje się obecnie bardziej powszechne i dostępne dla każdego.

\subsection{FORMY DZIALALNOŚCI E-COMMERCE}

Aukcja to według prawa polskiego odrębna forma sprzedaży, a aukcja internetowa, jak nazwa wskazuje, oznacza sprzedaż produktów w Internecie. Formę i swoistą zawartość aukcji określają ściśle przepisy polskiego Kodeksu Cywilnego. Trzeba wziąć jednakże pod uwagę, że w niektórych przypadkach aukcja internetowa nie spełni założeń aukcji tradycyjnej, przykładem jest aukcja internetowa w formie „Kup teraz!".

Najbardziej charakterystyczną cechą aukcji internetowej jest to, że całe postępowanie sprzedażowo-aukcyjne jest przeprowadzane poprzez szerokie zastosowanie porozumiewania się „na odległość” . Z aukcją internetową związany jest termin - cena minimalna. Chodzi tu o to, że sprzedający zanim rozpocznie aukcję, ma możliwość określenia swojej ceny minimalnej za dany produkt, od której

\footnotetext{
${ }^{6}$ A. Benicewicz-Miazga, E-business w Internecie i multimediach, Mikom, 2013, s. 75.

${ }^{7}$ K.C Laudon, C.G. Taver, E-commerce, business, technology, society, 2014, s. 112.

${ }^{8}$ P. Sztompka, op. cit., s. 23-42.

${ }^{9}$ Kontinuum elektronicznego biznesu z perspektywy użtkownika, „Infoman”, nr 7/8, 1999, s. 30.
} 
zacznie się licytacja. W momencie, gdy aukcja zakończy się, a kwota nie uzyska minimum, aukcja pozostaje jako niesprzedana ${ }^{10}$.

Obecnie można spotkać się z kilkoma rodzajami aukcji o charakterze internetowym. Najpopularniejsze z nich, to m.in. ${ }^{11}$ :

- Aukcja klasyczna, nazywana także angielska

Jest to rodzaj najbardziej zbliżony swoją formą do tradycyjnych aukcji. Licytowany jest tu jeden konkretny przedmiot, a całą licytację wygrywa ta osoba, która wylicytuje największą cenę, warunkiem wygranej jest jednak to, aby cena ta była wyższa niż podana na początku cena wywoławcza.

- Aukcja zawierająca opcję „kup teraz”

Osoba sprzedająca towar ma możliwość wyznaczenia ceny zakupu tegoż produktu w trybie natychmiastowym. Oznacza to, że za określoną cenę kupujący może zakupić dany przedmiot zanim aukcja dobiegnie końca. Współczesne internetowe portale aukcyjne dają sprzedającym możliwość lączenia ze sobą licytacji i opcji „kup teraz”. Na portalach znaleźć można mnóstwo aukcji, które mają zaopcjowaną jedynie możliwość zakupu natychmiastowego, zazwyczaj są to aukcje firm, które takie portale uważają za doskonałą możliwość dotarcia do zwiększonego zakresu klienteli.

\section{- Aukcja wieloprzedmiotowa}

Wiele działających na rynku serwisów aukcyjnych daje sprzedającym możliwość wystawienia na jednej aukcji kilku takich samych przedmiotów. Wtedy dla kupującego pojawia się dodatkowa opcja umożliwiająca dokładne określenie ilości kupowanych rzeczy. W momencie, gdy mamy do czynienia $z$ licytacją, towar na niej sprzedawany, po zakończeniu aukcji jest odsprzedawany za cenę najniższą z tych wszystkich, które tę aukcję wygrały ${ }^{12}$.

\section{- Aukcja grzecznościowa}

Ten rodzaj aukcji internetowej jest właściwie zabroniony przez większość poważnych serwisów aukcyjnych. Polega ona na tym, że oferowany przedmiot nie jest własnością sprzedającego, a on jedynie pośredniczy w sprzedaży, czyli wystawia ogłoszenie „grzecznościowo"13.

Serwis ogłoszeniowy jest typem serwisu internetowego, na łamach którego każdy użytkownik może zamieścić ogłoszenie o ustalonej przez siebie treści. Taki serwis pomaga w kojarzeniu ze sobą kupującego i sprzedającego, a także daje użytkownikom możliwość dokładnego przejrzenia i stałego dostępu do interesującego ich działu ogłoszeń. Osoby, które zamieszczają na takich portalach swoje ogłoszenia, dla ułatwienia szukania zazwyczaj katalogują je w skonkretyzowanych grupach tematycznych.

\footnotetext{
${ }^{10}$ W. Cellary, Elektroniczny Biznes, Bezpieczna gospodarka elektroniczna, Wydanie specjalne Net Forum, 2000, s. 5.

${ }^{11}$ M. Castells, Społeczeństwo sieci, Wydawnictwo Naukowe PWN, Warszawa 2007, s. 76.

${ }^{12}$ A. Afuah, C. L. Tucci, op. cit., s. 22-26.

${ }^{13}$ W. Cellary, op. cit., s. 5.
} 
Sklep internetowy to nic innego jak rodzaj serwisu internetowego, który daje człowiekowi możliwość zakupu i sprzedaży ogromnego wachlarza produktów poprzez Internet. Jest to jednym słowem jedna $z$ najważniejszych form handlu elektronicznego, dostępnego współcześnie dla ludzi. Ta forma działalności e-commerce zazwyczaj jest częścią modelu B2C, dużo rzadziej można go przypisać do modelu B2B. Współcześnie jest to metoda niezwykle popularna, ze względu na ogromną wygodę zakupów i znaczne obniżenie kosztów ponoszonych przy sprzedaży produktu. Dodatkowo kupujący mają możliwość niemal natychmiastowego porównania cen u kilku sprzedających ${ }^{14}$.

Podstawą działania sklepu internetowego jest dobrze przygotowana witryna www, na której kupując można szczegółowo zapoznać się z ofertą danego sklepu, a także po zarejestrowaniu złożyć zamówienie. Sklep internetowy ogólnie składa się z: strony z całą ofertą sklepu, tzw. podstrony zawierającej pogrupowane systematycznie produkty i ich opisy, koszyka, do którego można dodawać kilka produktów, a na koniec zapłacić za wszystkie jednocześnie, formularza, w którym kupujący zostawiają wszystkie potrzebne dane kontaktowe do siebie, takie jak adres korespondencyjny, adres e-mail, numer telefonu, panelu administracyjnego ${ }^{15}$.

Sklep internetowy jest bardzo szczególnym typem aplikacji z rodzaju e-commerce, który umożliwia jednoczesne przeprowadzenie transakcji pomiędzy kupującym i sprzedającym, a także umożliwia szybki rozwój ${ }^{16}$. Przy zakładaniu sklepu internetowego należy zwrócić baczną uwagę na oprogramowanie, jakie zostanie zainstalowane. Wiadomo, że podstawą dobrego sklepu jest dobre oprogramowanie komputerowe. Dokładniej rzecz biorąc można powiedzieć, że rzeczony sklep składa się z dwóch odrębnych aplikacji:

Część wewnętrzna - chodzi tu przede wszystkim o panel administracyjny, który jest dostępny dla określonej grupy osób, zazwyczaj dla administratora tegoż sklepu oraz jego właściciela. Składa się on z szeregu narzędzi, które umożliwiają pełną i odpowiedzialną administrację strukturą konkretnej strony www. Zapewnia ona wiele różnorodnych możliwości rozwoju strony sklepu, mianowicie ${ }^{17}$ :

- można dodawać nowe kategorie i podkategorie dla sprzedawanych produktów,

- istnieje możliwość edytowania dotychczasowych ofert,

- można zarządzać kontami klientów oraz zawartą na stronie treścią,

- istnieje możliwość kontroli zamówień i sposobu płatności za zakupiony towar,

- zapewnia edytor tekstu z wieloma przydatnymi funkcjami,

- można wystawiać paragony, faktury VAT i przeprowadzać szereg innych operacji charakterystycznych dla sklepu internetowego.

\footnotetext{
${ }^{14}$ A. Hartman, J. Sifonis, J. Kador, E-biznes - strategie sukcesu w gospodarce internetowej, Warszawa 2001, s. 26.

${ }^{15}$ M. Marczuk, Krótka charakterystyka nowej gospodarki [w:] Internet - fenomen społeczeństwa informatycznego, Wydawnictwo Edycja Św. Pawła, Częstochowa 2011, s. 23-42.

${ }^{16}$ M. Niedźwiedziński, Globalny handel elektroniczny, Warszawa 2004, s. 29.

${ }^{17}$ A. Hartman, op. cit., s. 26.
} 
Część zewnętrzna - wizualny wygląd strony internetowej konkretnego sklepu. Stanowi ona swoistą wizytówkę firmy, zaprezentować tam można całą jej ofertę sprzedażową. Użytkownicy mają zapewniony nieograniczony dostęp do szeregu produktów poprzez wykorzystanie szeregu pomocnych elementów. Strona www daje możliwość wyszukania interesującego nas produktu oraz natychmiastowej płatność za niego w systemie online. System znajdujący się w części zewnętrznej jest całkowicie zintegrowany z elektronicznymi płatnościami, aby jak najbardziej ułatwić klientom zakupy na konkretnej stronie ${ }^{18}$.

Omawiając tę jakże złożoną aplikację e-commerce, trzeba koniecznie zaznaczyć, że jej założenie nie jest wcale takie proste. Funkcjonalność takiej platformy internetowej powinna być niezwykle rozbudowana, aby każdy z klientów mógł na niej znaleźć coś dla siebie. Najważniejszymi kwestiami warunkującymi sukces sklepu internetowego, są: bezawaryjność portalu, niezwykle wysoka jakość wykonania strony www, odpowiednie zabezpieczenie dokonywanych w sklepie transakcji, skuteczna promocja strony na innych portalach internetowych.

W przypadku sklepu internetowego trzeba również pamiętać, że musi on bezsprzecznie spełniać wszystkie najwyższe standardy panujące współcześnie. Jest to ważne dla dorównania jakością innym portalom oraz do wyznaczania całkiem nowych trendów w dziedzinie e-commerce. Obecnie można zaobserwować bardzo szybki rozwój handlu elektronicznego, gdzie konkurencyjność rośnie dosłownie z dnia na dzień. Dlatego też, zakładając sklep internetowy, trzeba zdawać sobie sprawę, że nie sztuką jest go stworzyć, sztuką jest go utrzymać i jeszcze na nim zarabiać ${ }^{19}$.

Warto wspomnieć także o tym, że właściwie wszystkie sklepy internetowe preferują kontakt z kupującym poprzez pocztę elektroniczną. Niektóre z nich jednak, dają również możliwość skontaktowania się z konsultantem, czy to bezpośrednio czy telefonicznie. Coraz popularniejsze staje się kontaktowanie z konsultantami za pomocą Internetu czy różnych aplikacji komunikacyjnych typu Skype. Sklepy używają także różnego typu komunikatorów tekstowych, takich jak np. Gadu-gadu.

Do odpowiedniej obsługi sklepu internetowego służą specjalnie opracowane oprogramowania komputerowe. Najpopularniejsza formą jest korzystanie z gotowych szablonów programowych, które każda firma dostosowuje jedynie do swoich własnych celów, głównie w kwestiach związanych z szatą graficzną i ogółem funkcjonowania. Niektóre sklepy jednak korzystają z programów stworzonych na ich indywidualne zamówienie, dopasowanych do konkretnych potrzeb. Cechują się one doskonałym dopasowaniem do celów, jakie realizuje dany sklep.

Współcześnie często spotkać można się z sytuacją kiedy duże, tradycyjne sklepy nie są w stanie sprostać konkurencji, jaką stanowią dla nich sklepy internetowe i po prostu upadają. Taka sytuacja dotyka sklepy ze wszystkich istniejących branż

\footnotetext{
${ }^{18}$ Ibidem, s. 26-28.

${ }^{19}$ M. Niedźwiedziński, op. cit., s. 29.
} 
i na każdym kontynencie. Sklepy internetowe to przyszłość handlu i zapowiada się, że sytuacja ta nie ulegnie zmianie, chyba że na lepsze. Wirtualna giełda to typ serwisu internetowego, który stanowi miejsce wirtualnych spotkań, mających na celu sprzedaż określonych w sposób szczegółowy towarów, po restrykcyjnie ustalonej cenie opartej na codziennych notowaniach.

W przypadku e-commerce istnieje jeszcze kilka innych rodzajów handlu elektronicznego, które nie są jednak tak popularne jak te wymienione powyżej. Strategia marketingowa e-commerce nazywana jest często strategią e-marketingową lub po prostu strategią marketingową usytuowaną w Internecie ${ }^{20}$. Uznawana jest ona powszechnie za bardzo znaczącą część ogółu strategii marketingowo-rozwojowej całego przedsiębiorstwa. W takiej firmie elektronika, Internet i różnorodne media cyfrowe stanowią podstawę wsparcia dla innych występujących w niej kanałów sprzedaży i komunikacji. Aby stworzyć odpowiednią dla konkretnej firmy strategię e-marketingową, osoby ją tworzące muszą mieć jasno i bardzo precyzyjnie wytyczone cele, w jakich elementach tej strategii będą wykorzystywały skomplikowane kanały internetowe tzw. online ${ }^{21}$.

Przyglądając się strategii marketingowej e-commerce od podstaw, należy w pierwszej kolejności zwrócić uwagę na kwestie, jakie trzeba zbadać zanim zacznie się taką strategię tworzyć.

$\mathrm{Na}$ strategię e-marketingową w Internecie oddziałują przez cały czas dwa główne typy czynników, mianowicie: wewnętrzne i zewnętrzne. Do obu tych grup zalicza się po kilka najbardziej podstawowych czynników, charakterystycznych dla nich $^{22}$. Czynniki wewnętrzne to: cele, jakie postawione zostają przedsiębiorstwu i jego e-marketingowi oraz odpowiedni dobór strategii organizacyjnej, trafione, dokładne oraz niezwykle szczegółowe opracowanie zagadnień dotyczących strategii marketingowej ${ }^{23}$.

Czynniki zewnętrze, które w znacznym stopniu wpływają na strategię marketingową e-commerce, to przede wszystkim: dokładna analiza struktur współczesnego rynku, a także spraw związanych z kondycją popytu w kraju, wywiad mający na celu sprawdzenie treści strategii, jaką w swojej pracy kieruje się konkurencja, szczegółowe poznanie nowych możliwości, a także zagrożenia, jakie mogą oddziaływać na firmę w każdej chwili.

Do stworzenia odpowiedniej strategii e-marketingowej można podejść na kilka sposbów ${ }^{24}$. Najpopularniejsze obecnie są dwa modele tworzenia tej strategii. Zostały one opracowane przez agencje UserPilot (konkretnie przez Jacoba Orquina) oraz przez Guava Media.

\footnotetext{
${ }^{20}$ A. Afuah, C. L. Tucci, op. cit., s. 23-34.

${ }^{21} \mathrm{~W}$. Szpringer, Prowadzenie działalności gospodarczej $w$ Internecie: od e-commerce do e-businessu, Centrum Doradztwa i Informacji DIFIN, Warszawa 2005, s. 12-53.

${ }^{22}$ B. Gregor, M. Stawiszyński, E-Commerce, Oficyna Wydawnicza BRANTA, Łódź 2002, s. 10-32.

${ }^{23}$ Ibidem, s. 10.

${ }^{24}$ A. Afuah, C. L. Tucci, op. cit., s. 23-24.
} 


\subsection{KIERUNKI ROZWOJU E-COMMERCE}

Ostatnia dekada przyniosła zaskakujące zmiany, jeśli chodzi o rynek e-commerce. O ile w 2006 roku funkcjonowało na rynku polskim zaledwie 2800 sklepów internetowych, o tyle już w 2008 roku było ich 4500. 2010 rok przyniósł wzrost liczby witryn o ponad połowę, co daje ok. 10000 e-sklepów. Obecnie szacuje się, że liczba sklepów internetowych może wahać się pomiędzy 15 000, a nawet 20000. Biorąc pod uwagę wartość e-handlu, to w 2013 roku wyniosła ona 26 mld PLN, a w 2014 osiągnęła poziom 30 mld PLN ${ }^{25}$.

Rozwój rynku e-commerce niewątpliwie wciąż będzie wykazywał tendencję wzrostową. O dynamice zmian zdecydują nie tylko działania promocyjne podejmowane przez e-sklepy, ale również umiejętność dostosowania oferty do oczekiwań konsumentów oraz postępu technologicznego.

Trzeba zdać sobie sprawę z faktu, że „dzisiejszy” e-commerce nie ogranicza się wyłącznie do Internetu i komputerów tradycyjnych czy notebooków. Coraz więcej urządzeń umożliwia dostęp do sieci. Jednak na szczególną uwagę zasługują: rozwój technologii bezprzewodowych i urządzenia mobilne (smartfony i tablety).

Zakupy internetowe za pośrednictwem urządzeń mobilnych nie są jeszcze tak popularnym zjawiskiem, jak w innych krajach europejskich. Przyczyn tego stanu można upatrywać choćby w kosztach połączenia $\mathrm{z}$ Internetem, problemach $\mathrm{z}$ obsługą płatności czy z nieprzystosowaniem stron sklepów internetowych do przeglądania na urządzeniach mobilnych. Jednak technologia idzie na przód i powoli te przeszkody zaczynają zanikać.

Kolejnym trendem, którego dynamiczny rozwój możemy obserwować w ostatnich latach, jest zjawisko social commerce (s-commerce). Jest to obszar handlu elektronicznego, który wspiera społeczne zachowania nabywców, w szczególności skłonność do nawiązywania relacji, wzajemne oddziaływanie internautów oraz współdziałanie podczas procesu podejmowania decyzji nabywczych ${ }^{26}$.

\section{Podsumowanie}

Dzięki e-commerce ludzie mają dużo większą możliwość na spróbowanie poprowadzenia swojej własnej firmy, bo każdemu wydaje się, że nie jest to zbyt kłopotliwa działalność. Często jest to jednak mylne przeświadczenie, dlatego zanim ktokolwiek zdecyduje się na prowadzenie e-biznesu powinien dokładnie zapoznać się z materiałami na temat $e$-commerce. Każdy użytkownik sieci internetowej musi

\footnotetext{
${ }^{25} \mathrm{http} / / /$ www.forbes.pl/rozwoj-rynku-e-commerce-w-polsce,artykuly,195234,1,1.html [01.03.2016].

${ }^{26}$ M. Brzozowska-Woś, Wybrane instrumenty zintegrowanej komunikacji marketingowej [w:] Zintegrowana działalność promocyjna na rynkach krajowych i międzynarodowych, Wyd. Wydziału Zarządzania Politechniki Częstochowskiej, Częstochowa 2010, s. 106-113.
} 
zdawać sobie sprawę, że e-biznes to przyszłość ludzkości, dlatego też trzeba skupiać wiele działań i pracy na tym, aby te dziedziny gospodarki mogły się stale i szybko rozwijać. Będzie to korzystne dla każdego człowieka.

\section{Bibliografia}

Afuah A., Tucci C. L., Biznes internetowy strategie i modele, Kraków, 2003.

Benicewicz-Miazga A., E-business w Internecie i multimediach, Mikom, 2013.

Brzozowska-Woś M., Wybrane instrumenty zintegrowanej komunikacji marketingowej, [w:] A. Pabian (red.) Zintegrowana działalność promocyjna na rynkach krajowych i międzynarodowych, Wyd. Wydziału Zarządzania Politechniki Częstochowskiej, Częstochowa 2010.

Castells M., Społeczeństwo sieci, Wydawnictwo Naukowe PWN, Warszawa 2007.

Cellary W., Elektroniczny Biznes, Bezpieczna gospodarka elektroniczna, Wydanie specjalne Net Forum, 2000.

Charlesworth A., Key concepts in e-commerce, Palgrave Macmillan, 2007.

Gregor B., Stawiszyński M., E-Commerce, Oficyna Wydawnicza BRANTA, Łódź 2002.

Hartman A., Sifonis J., Kador J., E-biznes - strategie sukcesu w gospodarce internetowej, Warszawa 2001.

Kontinuum elektronicznego biznesu z perspektywy użytkownika, „Infoman”, nr 7/8, 1999.

Laudon K. C., Taver C. G., E-commerce, business, technology, society, 2014.

Maciejewski J., Salak M., Społeczeństwo informacyjne a współczesne technologie teleinformatyczne, „Zeszyty Naukowe Wyższej Szkoły Zarządzania i Prawa w Warszawie”, nr 2, Warszawa 2004.

Marczuk M., Krótka charakterystyka nowej gospodarki [w:] Internet - fenomen społeczeństwa informatycznego, (red.) T. Zasępa, Wydawnictwo Edycja Św. Pawła, Częstochowa 2011.

Niedźwiedziński M., Globalny handel elektroniczny, Warszawa 2004.

Olszak C. M., Systemy e-commerce. Technologie internetowe w biznesie, Katowice 2004.

Szpringer W., Prowadzenie działalności gospodarczej w Internecie: od e-commerce do e-businessu, Centrum Doradztwa i Informacji DIFIN, Warszawa 2005.

Sztompka P., Socjologia zmian społecznych, Wyd. Znak, Kraków 2010.

http://www.forbes.pl/ [01.03.2016]. 
Magda Zięba

Uniwersytet Łódzki

Katedra Logistyki

ul. Matejki 22/26, 90-237 Łódź

\section{Internet Fizyczny jako przełom w zarządzaniu lańcuchami dostaw}

\section{WPROWADZENIE}

W obecnych czasach przedsiębiorstwa stają w obliczu wyzwań, które powinny być podjęte, aby zgodnie z polityką zrównoważonego rozwoju zapewnić przyszłym pokoleniom dostępność zasobów na podobnym poziomie. W związku z postępującą degradacją środowiska, niepełnym wykorzystywaniem potencjału globalnej logistyki zaopatrzenia, produkcji, i dystrybucji oraz z poziomem jakości życia zawodowego i rodzinnego pracowników sektora transportu, istnieje potrzeba globalnych zmian. Przyczyn tychże nieefektywności upatruje się w sposobie, w jaki obecnie transportowane i magazynowane są produkty. Koncepcją, która może zmienić status quo, jest według jej twórców idea Internetu Fizycznego, która może zrewolucjonizować zasady zarządzania łańcuchami dostaw.

Celem niniejszego rozdziału jest prezentacja innowacyjnego podejścia do organizacji procesów logistycznych, jakim jest koncepcja Internetu Fizycznego. Pierwsza część stanowi o obecnych problemach, z jakimi zmaga się branża logistyczna. Dalej autorka przedstawia propozycję ich rozwiązania, przywołując wspomnianą koncepcję. Kolejna część rozdziału poświęcona jest korzyściom oraz wyzwaniom w związku z możliwością wdrożenia tegoż rozwiązania.

\subsection{Problemy I WYZWANia WSPÓlCZESNeJ LOgISTYKi I ZARZĄDZANia LAŃCUCHEM DOSTAW}

Współczesna logistyka i łańcuchy dostaw zmagają się z wieloma problemami. Istnieje szereg przyczyn, które nie pozwalają na osiągnięcie większej wydajności procesów. Sposób, w jaki zasoby materialne są transportowane, przechowywane i dystrybuowane jest nieefektywny w każdym $\mathrm{z}$ trzech aspektów: ekonomicznym, społecznym i środowiskowym. Obecnie przed zarządzaniem procesami logistycznymi stoi wiele przeszkód, które często wynikają z samej organizacji procesu lub istniejącej infrastruktury. Należy je właściwie określić i zidentyfikować, aby uświadomić istotną potrzebę zmian. $Z$ uwagi na to, że branża logistyczna stanowi 
ok. 14\% globalnego $\mathrm{PKB}^{1}$, a jej wzrost jest szybszy niż ogólny wzrost światowego handlu, warto podjąć kroki do wprowadzenia usprawnień.

Jednym z czynników, prowadzących do nierównowagi środowiskowej i ekonomicznej, jest niepełne wykorzystanie przestrzeni ładunkowej. Często mówi się, że samochody przewożą powietrze, dlatego, że zdarza się, iż jeżdżą w połowie puste. Nie wynika to jedynie z braku towaru, ale także ze struktury opakowań, które nie są dopasowane do kształtu produktu oraz niestandardowych wymiarów paczek. Szacuje się, że w pełni załadowany samochód, naprawdę przewozi $60 \%$ możliwego załadunku. Co więcej, w trakcie przewozu, pojazdy są systematycznie rozładowywane i inne ładunki nie zapełniają tej wolnej przestrzeni. Należy w tym miejscu wspomnieć również o pustych przewozach, które są raczej normą niż wyjątkiem. Kierowcy w drodze powrotnej jadą pustymi samochodami lub przewoźnicy szukają dla nich ładunku w okolicy, który mogliby zabrać. W Polsce w przypadku przewozów krajowych, puste przebiegi stanowią 27\% kilometrażu, natomiast $\mathrm{w}$ przewozach międzynarodowych $13 \%{ }^{2}$. To bardzo niepokojące dane $\mathrm{z}$ uwagi na to, że procesy transportowe są największymi konsumentami energii na świecie w przekroju gałęzi gospodarki.

Należy wspomnieć również o nadmiernym przemieszczaniu produktów, czego można uniknąć, przenosząc produkcję blisko rynków zbytu. Przykładowo, łosoś norweski jest często transportowany do Chin, gdzie pakuje się go przed wysyłką do innych krajów, w tym do Szwecji czy Finlandii. Outsourcing produkcji do krajów rozwijających się niestety uwypukla to zjawisko.

Kolejnym problemem jest wciąż zbyt mała rola transportu intermodalnego. Istnieje wiele prominentnych przykładów jego wykorzystania w przewozach towarowych, ale to wciąż niewiele. Trasy są ryzykowne i nieefektywne pod względem czasu i kosztów. Taka sytuacja wzmaga kongestie i tym samym emisję CO2. Bardziej zrównoważony transport powinien stać się standardem w zarządzaniu łańcuchami dostaw.

Współczesna logistyka zmaga się również z problemem dostarczania towarów do centrów miast. Wiele aglomeracji nie jest zaprojektowanych, by sprzyjać transportowi ładunków i magazynowaniu. Powoduje to kongestie, wzmożony hałas oraz zanieczyszczenie środowiska. Fakt ten jest tym bardziej dotkliwy z uwagi na stale rosnącą liczbę mieszkańców miast. Stąd potrzeba stałego rozwoju logistyki miejskiej, w ramach której implementowanych jest coraz więcej ciekawych rozwiązań.

Pozostając przy transporcie, nie sposób nie wspomnieć o niedogodności pracy kierowców. W Unii Europejskiej w przemyśle transportowym pracuje obecnie ok. $10 \mathrm{mln}$ osób. Ich zdrowie i życie są stale narażone na ryzyko. Praca ta jest nużąca i męcząca. Według Narodowej Rady Bezpieczeństwa Transportu, 58\%

\footnotetext{
${ }^{1}$ http://www.plpt.com.pl/do_pobrania/plpt_4.pdf [12.01.2016].

${ }^{2}$ Transport pod lupa, Europejski Program Modernizacji Polskich Firm, 2013, s. 14-15.
} 
wypadków spowodowanych przez kierowców wynikało z ich przemęczenia i braku snu. Praca kierowców wpływa także negatywnie na ich życie rodzinne i towarzyskie.

Problem stanowi również niewłaściwe zarządzanie infrastrukturą magazynową. Wiele magazynów jest wykorzystywanych dopiero podczas tzw. peaków popytu, co oznacza, że przez większość roku ich utrzymanie generuje straty. Inne natomiast są zapełnione produktami, które niepotrzebnie są przechowywane w magazynach i nie rotują, co jest spowodowane przede wszystkim trudnościami w prognozowaniu popytu. Produkty są magazynowane $\mathrm{w}$ nieodpowiednich ilościach i lokalizacjach względem rynków zbytu, stąd nie docierają do klientów odpowiednio szybko. To oczywiste, że każde ogniwo łańcucha dostaw posiada zapasy, jednak nie gwarantuje to wysokiego poziomu obsługi klienta. Taka sytuacja prowadzi do tego, że wiele towarów może w ogóle nie zostać sprzedanych. Jest ona typowa zwłaszcza dla branży spożywczej i odzieżowej, gdzie produkty szybko się starzeją. Część produktów nie dociera do klientów, którzy najbardziej ich potrzebują. Problem ten dotyka głównie ubogie kraje, które nie posiadają odpowiedniej infrastruktury, ale pojawia się również w warunkach klęsk i kryzysów.

Obecnie menedżerowie powinni być świadomi, ile korzyści niesie ze sobą budowanie partnerskich relacji w łańcuchach dostaw. Niestety zauważa się brak skłonności do współpracy, co powoduje, że sieci przedsiębiorstw nie są wystarczająco mocne i bezpieczne. W związku z tym nie są oni w stanie skutecznie zarządzać ryzykiem, które niosą ze sobą kradzieże, terroryzm, katastrofy naturalne czy kryzysy ekonomiczne. Dochodzą do tego odmienne standardy branżowe, np. w Europie, Ameryce i Azji używa się palet o innych wymiarach. Na poziomie małych i średnich przedsiębiorstw należy wskazać na brak automatyzacji w organizacji procesów oraz niewielkie wykorzystanie jednakowych standardów. Brak ogólnych norm powoduje również swoiste hamowanie innowacji. Innowacje są wstrzymywane z uwagi na niewypracowane kanony. Przenośniki, wózki widłowe czy systemy magazynowe są niektórymi z przykładów. W ostatnich latach nie było w tych obszarach znaczących, przełomowych innowacji.

Wszystkie wyżej wymienione symptomy prowadzą do nierównowagi ekonomicznej, ekologicznej oraz społecznej w logistyce i zarządzaniu łańcuchami dostaw. Ostatnie lata przyniosły znaczny wzrost stężenia $\mathrm{CO}_{2} \mathrm{w}$ atmosferze. Doprowadziło to do przyjęcia długoterminowych planów mających na celu ustanowienie polityki zrównoważonego rozwoju, w tym w obszarze transportu. W 2011 roku Komisja Europejska opublikowała Białą Księgę, która wskazuje, że do roku 2030 emisja gazów cieplarnianych pochodzących z transportu musi zmniejszyć się o $30 \%$ w stosunku do roku 2008 i o $60 \%$ w porównaniu do roku $1990^{3}$. Ponadto

${ }^{3}$ http://ec.europa.eu/transport/themes/strategies/doc/2011_white_paper/white-paper-illustrated-brochure_pl.pdf [12.01.2016]. 
należy zastanowić się także nad zwiększeniem wydajności procesów logistycznych i poprawą jakości życia pracowników zatrudnionych w tej branży.

\subsection{KONCEPCJA INTERNETU FIZYCZNEgo}

Odpowiedzią na powyższe wyzwania jest znalezienie kompleksowego, innowacyjnego rozwiązania systemowego, które zapewni wzrost efektywności realizacji procesów i rozwój logistyki przy równoczesnym zachowaniu równowagi ekologicznej, ekonomicznej i społecznej. Próbę opracowania takiego systemu podjęło kilka grup badaczy z Ameryki Północnej i Europy. Wśród nich B. Montreuil z Uniwersytetu Laval w Kanadzie, który jako pierwszy wprowadził pojęcie Fizycznego Internetu (ang. Physical Internet), oznaczanego $\mathrm{z}$ alfabetu greckiego jako $\pi$. Internet Fizyczny stanowi metaforę działania dotychczas znanego i powszechnie używanego Internetu cyfrowego w świecie rzeczywistym. Podstawą współczesnych technologii sieciowych jest protokół sieciowy TCP/IP (ang. Transmission Control Protocol/Internet Protocol), dzięki któremu Internet cyfrowy działa z niewyobrażalną prędkością i efektywnością. Umożliwia on łączenie różnych komputerów, systemów operacyjnych i programów w jedną, uniwersalną sieć niezależnie od systemu czy sprzętu. Punktem wyjścia do zrozumienia wizji Internetu Fizycznego jest poznanie, jak działa komunikacja przy użyciu protokołu TCP/IP. Otóż elementarnym pojęciem w Internecie cyfrowym jest pakiet zawierający zagregowane informacje, które mają być przesłane. Wysyłane strumienie danych dzielone są na części zamykane w tych właśnie pakietach. Komputer docelowy odbierający pakiety, wyciąga $\mathrm{z}$ nich dane i skleja w strumień informacji zrozumiały dla programu, który ich oczekuje (np. przeglądarki internetowe czy poczta mailowa) ${ }^{4}$. Każdy pakiet podróżuje niezależnie od innych. Dociera do miejsca przeznaczenia dzięki temu, że dołączona jest do niego informacja o tym, skąd pochodzi, dla kogo jest przeznaczony i jakiego rodzaju dane przenosi.

Dzięki pakietom jedna pojedyncza informacja nie jest przesyłana. Tak samo może być z obiektami materialnymi. Już teraz w logistyce mamy do czynienia ze swoistymi „pakietami danych”, czyli kontenerami. Natomiast najwięksi gracze rynkowi tacy, jak DHL, FedEx czy UPS ustandaryzowali rozmiary obsługiwanych paczek. Praktyka ta stanowi fundamenty do zrozumienia działania Internetu Fizycznego, który zakłada możliwość transportowania wszystkiego wszędzie w najbardziej efektywny sposób. Internet cyfrowy działa dokładnie tak samo z informacjami. Jednak obecna infrastruktura logistyczna potrzebuje dużych zmian, by sprostać takiemu wyzwaniu.

Internet Fizyczny (nazywany także Internetem Logistycznym lub Internetem Dóbr Materialnych) jest zatem otwartym, globalnym systemem logistycznym opartym na fizycznej, cyfrowej i operacyjnej łączności osiąganej dzięki modular-

${ }^{4}$ http://www.pcworld.pl/artykuly/290576/TCP.IP.w.pigulce.html [12.01.2016]. 
nym jednostkom ładunkowym, połączonej infrastrukturze oraz kompleksowej wymianie danych. Jest to nowatorska idea, prezentująca jak lepiej projektować i integrować łańcuchy dostaw. Internet Fizyczny tworzy sprawnie działającą, nienaruszającą równowagi ekologicznej, odporną na zagrożenia Sieć Logistyczną. Składają się na nią otwarty rynek transportowy, wspólne sieci dostaw i procesy logistyczne, które są realizowane z wykorzystaniem otwartych, współdzielonych zasobów. Innowacyjność XXI wieku w coraz mniejszym stopniu dotyczy działalności $\mathrm{w}$ pojedynkę. Wiele przyczyn składa się na to, że ma ona $\mathrm{w}$ coraz większej mierze charakter gry zespołowej, w której przedsiębiorstwa różnych form i rozmiarów współpracują ze sobą ${ }^{5}$. Aby taki system działał z powodzeniem, niezbędna jest rozległa, kompleksowa komunikacja wśród wszystkich użytkowników i dzielenie się informacjami w czasie rzeczywistym. Wymiana danych jest kluczem do sukcesu dla powodzenia realizacji wizji Internetu Fizycznego.

Modularne jednostki ładunkowe ( $\pi$-kontenery) są kluczowym elementem założeń Internetu Fizycznego. Operacje logistyczne takie, jak transport, przeładunek, magazynowanie wszystkich towarów odbywają się z wykorzystaniem hermetycznych, inteligentnych, modułowych, przyjaznych środowisku i wystandaryzowanych jednostek ładunkowych. Mają one różne rozmiary, od wymiarów kontenerowych po małe jednostki. Taka standaryzacja zapewnia efektywniejsze wykorzystanie powierzchni ładunkowej i magazynowej. Dobór $\pi$-kontenera zależy od wielkości towarów. Ilustracji modularności budowy $\pi$-kontenerów służy następująca propozycja ich wymiarów wzdłuż osi X, Y, Z: 0,12 m, 0,24 m, 0,36 m, $0,48 \mathrm{~m}, 0,6 \mathrm{~m}, 1,2 \mathrm{~m}, 2,4 \mathrm{~m}, 3,6 \mathrm{~m}, 4,8 \mathrm{~m} \mathrm{i} 12 \mathrm{~m}^{6}$. Aby realizować podstawowe cele wynikające $\mathrm{z}$ wykorzystania $\pi$-kontenerów, wymiary te należy poddać międzynarodowej standaryzacji. Jednostki te są łatwe $\mathrm{w}$ transportowaniu środkami transportu drogowego, kolejowego i morskiego oraz w magazynowaniu, komponowaniu i dekompozycji większych zespołów kontenerów. Wykonane są z materiałów przyjaznych środowisku, a ich użytkowanie nie wpływa negatywnie na ekosystemy, ponieważ mogą one być wielokrotnie używane. Kontenery te wyposażone są $\mathrm{w}$ inteligentne etykiety (ang. smart tags) wykorzystujące technologię GPS, RFID czy kody kreskowe, umożliwiające ich identyfikację, zapewnienie bezpieczeństwa oraz monitorowanie lokalizacji w trakcie transportu i ułatwiające zarządzanie nimi, a także system regulujący wpływ czynników zewnętrznych na transportowane towary np. temperaturę. W wizji Internetu Fizycznego nie istnieją powszechnie wykorzystywane palety. Nie będzie konieczne także foliowanie towarów, co jest obecnie nieodłącznym elementem procesu. Taka specyfikacja $\pi$-kontenerów całkowicie zrewolucjonizuje dotychczasowe metody składowania

\footnotetext{
${ }^{5} \mathrm{~J}$. Tidd, J. Bessant, Zarządzanie innowacjami. Integracja zmian technologicznych, rynkowych i organizacyjnych, Wolters Kluwer, Warszawa 2011, s. 102.

${ }^{6}$ B. Montreuil, Toward a Physical Internet: meeting the global Logistics sustainability grand challenge, „Logistics Research”, 2011, s. 75.
} 


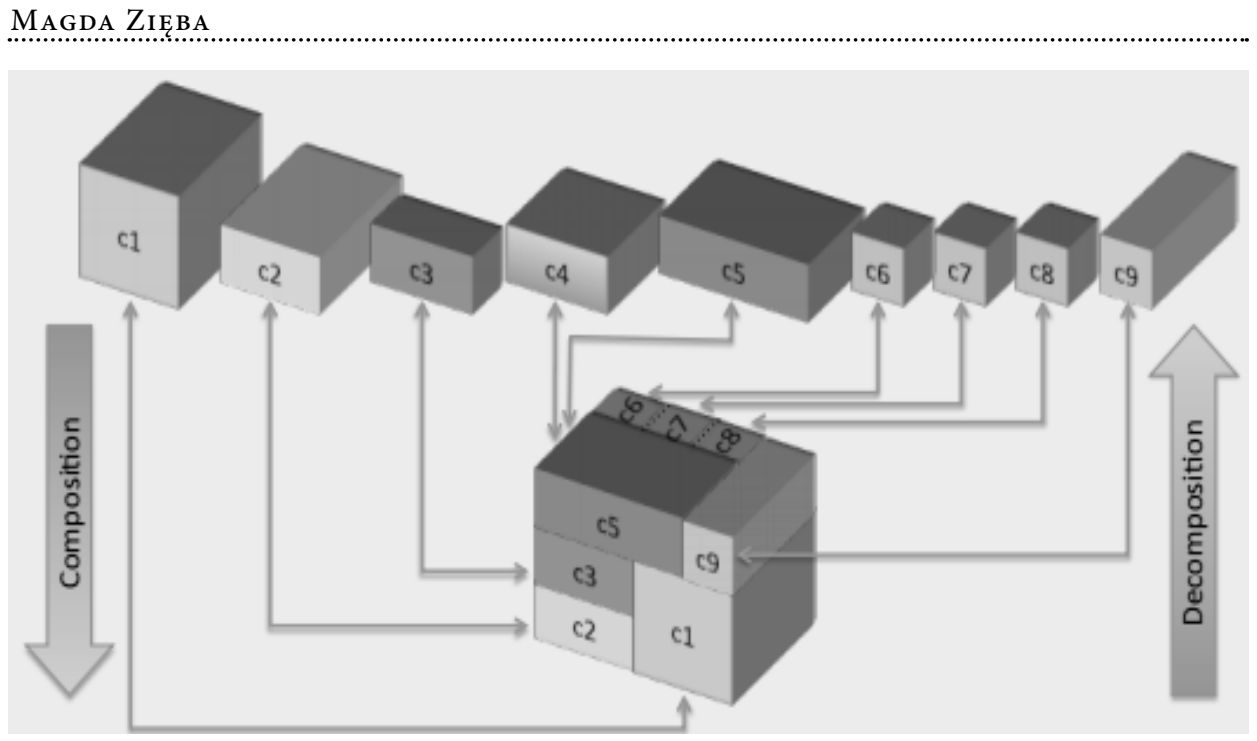

Rysunek 1. Przykład kompozycji modularnych jednostek ładunkowych

Źródło: https://www.cirrelt.ca/DocumentsTravail/CIRRELT-2011-03.pdf [06.01.2016].

i magazynowania towarów. Będą one składowane tak, jak obecnie składowane są kontenery w portach. Znikną zatem z magazynów tradycyjne regały. Modyfikacji będą musiały ulec także wózki widłowe i przenośniki. Charakterystyki współcześnie wykorzystywanych kontenerów czy paczek w ogóle nie mieszczą się w ramach takiej specyfikacji. Obecnie na świecie i w Europie prowadzone są rozmaite projekty badawcze mające na celu operacjonalizację koncepcji Internetu Fizycznego. Jednym z nich jest projekt MODULUSHCA (Modular Logistic Units in Shared Co-modal Networks) finansowany w ramach 7. Programu Ramowego Unii Europejskiej, którego partnerem w konsorcjum jest Instytut Logistyki i Magazynowania. Celem projektu jest opracowanie prototypów M-Boxów, czyli pojemników na towary, wykorzystywanych w multimodalnym transporcie lądowym. Posiadają one specjalne identyfikatory rozpoznawalne na całym świecie oraz czujniki i nadajniki pozwalające zachować pełną kontrolę w trakcie procesu transportowego. Mogą być wykorzystane jako jednostka transportowa oraz opakowanie zbiorcze na półce sklepowej ${ }^{7}$.

Koncepcja modularnych jednostek ładunkowych niesie ze sobą potrzebę zwrócenia uwagi na to, w jaki sposób są projektowane produkty. Już na etapie projektowania wyrobu musi być wzięta pod rozwagę konieczność umieszczenia go $\mathrm{w} \pi$-kontenerze. Wymiary towarów muszą być dostosowane do wystandaryzowanych wymiarów $\pi$-kontenera. Produkty powinny być projektowane tak, aby minimalizować ładunki i obciążenie. Tylko kluczowe elementy i części składowe

${ }^{7}$ http://www.plpt.com.pl/do_pobrania/plpt_4.pdf [12.01.2016]. 
wyrobu gotowego mogą być transportowane, wysyłane do odlegle zlokalizowanych odbiorców. $Z$ założenia dobra powinny być produkowane, finalnie montowane blisko rynku zbytu z wykorzystaniem lokalnie dostępnej infrastruktury.

Powszechna łączność wszystkiego i wszystkich ma być gwarantem sukcesu Internetu Fizycznego. Wymaga stworzenia specjalnego systemu, platformy, z którą połączone będą jednostki ładunkowe oraz wszyscy użytkownicy. Dzięki inteligentnym chipom, $\pi$-kontenery będą miały lączność ze sobą i z siecią $\mathrm{z}$ wykorzystaniem Internetu Rzeczy (ang. Internet of Things). Internet Rzeczy umożliwia wszechobecne połączenie urządzeń, przedmiotów wyposażonych $\mathrm{w}$ inteligentne technologie takie, jak RFID, GPS, sensory, Internet. Są one zatem "mądrzejsze” i zintegrowane ze sobą. Internet Fizyczny wykorzystuje możliwości IoT, by umożliwić globalną łączność $\pi$-kontenerów i całego systemu.

System Internetu Fizycznego zapewnia pełną kooperację podmiotów w łańcuchach dostaw. Wszyscy użytkownicy: producenci, operatorzy logistyczni, centra dystrybucyjne oraz magazyny klienta działają we własnych systemach informatycznych, a z systemem globalnym łączą się przy pomocy interfejsów. Standardowy protokół przesyłu danych, będący analogią do protokołu sieciowego TCP/IP, zawiera informacje o wysyłkach, potrzebach transportowych i magazynowych, gotowości przewozu $\pi$-kontenerów oraz o dostępnej powierzchni magazynowej. System optymalizuje przepływ $\pi$-kontenerów $w$ sieci poprzez wybór tras, miejsc przeładunku, łączenia ładunków i magazynowania ${ }^{8}$. Dzisiejsza logistyka zdominowana jest przez dostawy door-to-door oraz system hub-and-spoke. Internet Fizyczny ma ograniczyć tego typu rozwiązania. B. Montreuil zaprezentował możliwości oraz różnice wynikające z implementacji Internetu Fizycznego, posługując się przykładem przewiezienia ładunku z Quebecu do Los Angeles. Trasa ta w obie strony liczy ponad $10000 \mathrm{~km}$. W obecnych realiach jeden kierowca przewozi ładunek, co zajmuje mu co najmniej $240 \mathrm{~h}$. Ładunek dociera do punktu odbioru po ok. $120 \mathrm{~h}$. Następnie z dużym prawdopodobieństwem kierowca wraca pustym samochodem albo załadowanym jedynie częściowo, jeśli przewoźnikowi uda się znaleźć ładunek na drogę powrotną. W świecie Internetu Fizycznego powyższa sytuacja mogłaby przypominać sztafetę. Ten sam ładunek byłby przewożony przez 17 kierowców, którzy przekazywaliby go do następnego punktu tranzytowego po przejechaniu ok. $400 \mathrm{~km}$. Średni czas pracy kierowcy wyniósłby $6 \mathrm{~h}$ (wraz z drogą powrotną). Rozwiązanie znacząco podniosłoby jakość życia pracowników sektora transportowego. Z punktu tranzytowego w ciągu $1 \mathrm{~h}$ towar odbierałby następny kierowca, choć nie jest wykluczony także transport multimodalny. Tak zorganizowany proces zapewniłby dostarczenie ładunku w ciągu 60 h, czyli w czasie o połowę krótszym niż odbywa się to w obecnych realiach ${ }^{9}$. Aby powiódł się ten plan, wszystkie informacje

${ }^{8}$ http://www.plpt.com.pl/do_pobrania/plpt_4.pdf [12.01.2016].

${ }^{9}$ B. Montreuil, op. cit., s. 77-78. 
z systemów WMS poszczególnych użytkowników muszą być jawne i ogólnodostępne. Niezbędnym warunkiem jest wszechstronna współpraca, nawet konkurencyjnych łańcuchów dostaw. Internet Fizyczny ma zatem na celu znaczną poprawę wyników procesów logistycznych, podniesienie jakości usług przy jednoczesnej minimalizacji kosztów. To, że kooperacja się opłaca, wiadomo od dawna. Wiele przedsiębiorstw tworzy ze swoimi kontrahentami relacje partnerskie, by osiągać lepsze wyniki. Jednak współcześnie wciąż wiele sieci jest „zamkniętych". Niektóre przedsiębiorstwa na lata łączą się z jednym operatorem 3PL, który gwarantuje im kompleksową obsługę. Internet Fizyczny postuluje budowę Otwartej Globalnej Sieci Dostaw. W związku z tym, że ładunki będą transportowane i przechowywane w jednakowych jednostkach modularnych, magazyny i centra logistyczne będą mogły obsługiwać dużą liczbę klientów, a nie tak jak obecnie kilku. W samych tylko Stanach Zjednoczonych funkcjonuje obecnie 535000 magazynów i centrów dystrybucyjnych ${ }^{10}$. Internet Fizyczny i powołana w jego ramach otwarta sieć umożliwiłyby każdemu przedsiębiorstwu szybkie rozmieszczenie towarów w tych obiektach. Rozwiązanie to pozwoliłoby na rozlokowanie towarów w dużym rozproszeniu geograficznym w zależności od zgłaszanego popytu. Wyeliminowany zostałby problem braku dostępności produktu w lokalizacji, w której jest pożądany, ale niedostępny z uwagi na brak odpowiedniej infrastruktury. Ogólnie dostępna infrastruktura logistyczna dalaby dostawcom dostęp do zintegrowanych usług transportowych, pozwalając w efektywny ekonomicznie sposób zaspokoić wymogi logistyczne indywidualnych klientów ${ }^{11}$. Korzyściami płynącymi $\mathrm{z}$ takiej organizacji są m.in.: szybsza reakcja na zgłaszane potrzeby klientów, krótszy lead time, wyższa elastyczność, większa efektywność systemów Just in Time, skrócony czas dostawy, niższe koszty transportu na kilometr. Otwarta sieć pozwoliłaby także przedsiębiorstwom na osiąganie efektów skali.

\subsection{KORZYŚCI I BARIERY WDROŻENIA INTERNETU FIZYCZNEGo}

Koncepcja Internetu Fizycznego, chodź stosunkowo nowa, zyskuje na popularności. Zdążyła zwrócić już uwagę wielu przedsiębiorstw w tym takich korporacji, jak: Boeing, Chep, P\&G, Volvo, Walmart czy Hewlett-Packard oraz środowisk akademickich i organów rządowych. Wraz z postępem technologicznym pojawia się coraz więcej rozwiązań, które wpisują się w jego wizję i mogłyby pomóc w jego wdrożeniu. Na uwagę zasługują takie rozwiązania, jak druk 3D, pojazdy bezzałogowe, samochody nieangażujące do swojej obsługi kierowcy, np. samochody Google. Coraz powszechniejsze staje się wykorzystanie robotów w przemyśle, w tym w zarządzaniu magazynami. Amazon w swoich

\footnotetext{
${ }^{10} \mathrm{Ibidem}$, s. 80.

${ }^{11} \mathrm{http}: / / \mathrm{www} \cdot \log 24 . \mathrm{pl} /$ artykuly/logistyczny-internet,5846 [06.01.2016].
} 
magazynach wykorzystuje kilkanaście tysięcy robotów Kiva, które „manipulują" przesyłkami. Słynne jest także testowanie dronów przez Amazona czy DHL. Na popularności zyskują również ostatnio platformy Internetu Rzeczy np. Samsung Smart Home. Tego typu wynalazki nieuchronnie prowadzą zatem do implementacji w praktyce gospodarczej wizji na wzór Internetu Fizycznego, co może okazać się jedynym słusznym sposobem organizacji procesów logistycznych w przyszłości. Na świecie prowadzonych jest kilka projektów mających na celu rozwój tej idei i jej praktyczną implementację. Jednym z nich jest wspomniany wcześniej projekt MODULUSHCA. Nie sposób również nie wspomnieć o organizacji CELDi (ang. Center for Excellence in Logistics and Distribution) ze Stanów Zjednoczonych, której celem jest osiąganie doskonałości w logistyce i dystrybucji poprzez wdrażanie istotnych i innowacyjnych rozwiązań, które zapewnią członkom znaczny zwrot $\mathrm{z}$ inwestycji. O randze przedsięwzięcia, jakim jest Internet Fizyczny, świadczy fakt, że prace nad tym projektem są finansowane przez National Science Foundation. Internet Fizyczny jest także fundamentem obecnych działań Europejskiej Platformy Technologicznej w Logistyce ALICE, której misją jest rozwój nowych koncepcji i innowacji dla bardziej konkurencyjnego i zrównoważonego rozwoju. Postuluje ona rozwój transportu multimodalnego i inteligentnej, jednolitej sieci tworzonej przez korytarze transportowe i huby, co pozwoli na optymalizację w łańcuchach dostaw oraz wymaga zmiany $z$ dotychczasowego systemu na Internet Fizyczny ${ }^{12}$.

Istnieje zatem wiele cennych wartości, które niesie ze sobą implementacja owej wizji. Na większość z nich autorka zwróciła uwagę w poprzednich częściach rozdziału. Warto jednak podsumować najważniejsze z nich. Internet Fizyczny będzie redukował koszty poprzez eliminację pustych przewozów. Zminimalizuje to znacznie ślad węglowy. $Z$ efektów badań CELDi nad projektem Internetu Fizycznego w perspektywie oszczę- dności zasobów, wynika, że rocznie emisja CO2 zmalałaby o 233,8 $\mathrm{Tg}^{13}$. Liczba przejechanych kilometrów zmniejszyłaby się o ponad $130 \mathrm{mld}$, co przełożyłoby się na $65,8 \mathrm{mld}$ USD zaoszczędzonych na kosztach zakupów paliwa ${ }^{14}$.

Jednak poza optymistycznymi prognozami, istnieje szereg barier, które należy przezwyciężyć, aby Internet Fizyczny stał się rzeczywistością. Pierwszą z nich są oczywiście olbrzymie koszty infrastrukturalne. Wymiana sprzętu oraz zbudowanie całkiem nowego systemu pociągną za sobą duże nakłady. Jednak wizja sieciowości, polega także na tym, że korzyści ze wspólnej specjalizacji, wspólnego wykorzystywania infrastruktury i dzielenia przyjętych standardów oraz inne efekty ekonomiczne przewyższają koszty zarządzania siecią i jej utrzy-

\footnotetext{
${ }^{12} \mathrm{http}: / /$ www.etp-logistics.eu/?page_id=79 [06.10.2016].

${ }^{13} 1 \mathrm{Tg}=10^{9} \mathrm{~kg}$.

${ }^{14}$ http://faculty.ineg.uark.edu/rmeller/web/CELDi-PI/Final\%20Report\%20for\%20Phase $\% 2$ 0I.pdf [06.01.2016].
} 
mywania ${ }^{15}$. Taka rewolucja przyczyni się również początkowo do wzmożonej ilości odpadów. Ograniczona liczba wymiarów modularnych jednostek ładunkowych może tworzyć konflikty już na etapie projektowania wyrobów z uwagi na aspekty marketingowe. W związku z częstymi przeładunkami towarów w punktach tranzytowych i zmianami kierowców, istnieje ryzyko uszkodzeń, kradzieży, zaginięcia ładunków. Należałoby zatem zastanowić się również nad kwestią odpowiedzialności oraz ubezpieczenia towaru. Sporną kwestią mogą okazać się również opłaty pobierane przez przewoźników, a także dzielenie się przez nich informacjami o kosztach i cenach usług. Otwarta sieć może stworzyć problemy związane z własnością środków transportowych, magazynów i innych części infrastruktury. Wśród barier daleko posuniętej kooperacji mogącej powodować nadmierną koncentrację zasobów i kapitału wymienia się także ograniczenia ustawodawcze lub legislacyjne utrudniające bądź uniemożliwiające integra$c_{j e ̨ ̧}{ }^{16}$. Jednakże największą trudnością może okazać się zmiana sposobu funkcjonowania organizacji, postrzegania konkurencji i zmiana strategii przedsiębiorstw. Wdrożenie Internetu Fizycznego całkowicie zrewolucjonizuje sposób, w jaki firmy aktualnie funkcjonują na rynku. Jednak, jeśli nie poddadzą się tej transformacji, mogą nie przetrwać, bowiem innowacje polegają na nauce i zmianach, więc wiążą się często z dezorganizacją, ryzykiem i kosztami.

\section{Podsumowanie}

Współczesnym łańcuchom dostaw brakuje zadawalającej z punktu widzenia zrównoważonego rozwoju wydajności procesów. Procesy logistyczne wymagają innej organizacji, by móc w większym stopniu sprostać celom ekonomicznym, społecznym oraz środowiskowym. W ostatnich latach pojawiła się propozycja, która mogłaby diametralnie zmienić obecny stan, redukując tym samym ów nieefektywności. Rozwiązanie ma stanowić innowacyjna koncepcja Internetu Fizycznego, stanowiąca metaforę Internetu cyfrowego, którego założenia mają być przełożone na działanie procesów logistycznych w świecie rzeczywistym. Internet przesyła informacje zebrane $\mathrm{w}$ pakiety danych. Twórcy idei Internetu Fizycznego proponują, aby towary były transportowane $\mathrm{z}$ wykorzystaniem modularnych jednostek ładunkowych. Postulują oni budowę globalnego systemu logistycznego opartego na wspólnej infrastrukturze i powszechnej wymianie danych w czasie rzeczywistym. Taka sieć może znacznie przyczynić się do redukcji emisji dwutlenku węgla, a tym samym oszczędności zasobów. Reorganizacja procesów przyczyni się także do redukcji uciążliwości wynikających z pracy $\mathrm{w}$ sektorze transportowym. Jednak koncepcja spotyka się z wieloma barierami, głównie natury finansowej. Wymaga bowiem bardzo dużych nakładów celem

${ }^{15}$ J. Tidd, J. Bessant, op. cit., s. 394.

${ }^{16}$ A.M. Jeszka, Sektor usług logistycznych $w$ teorii i praktyce, Difin, Warszawa 2013, s. 40. 
budowy globalnego sytemu dostaw, dlatego wydaje się być dość odległą. Obecnie istnieje jednak już wiele nowoczesnych rozwiązań, które wpisują się w koncepcję Internetu Fizycznego, co może przemawiać za jej implementacją w przyszłości.

\section{Bibliografia}

Andel T., Supply Chain Managers get Physical with the Internet, „Material Handling\&Logistics”, February, 2012.

Jeszka A. M., Sektor usług logistycznych w teorii i praktyce, Difin, Warszawa 2013.

Montreuil B., Toward a Physical Internet: meeting the global Logistics sustainability grand challenge, „Logistics Research”, 2011.

Montreuil B., Rougès J. F., Cimon Y., Poulin D, The Physical Internet and Business Model Innovation, „Technology Innovation Management Review”, June, 2012.

Tidd J., Bessant J., Zarzadzanie innowacjami. Integracja zmian technologicznych, rynkowych i organizacyjnych, Wolters Kluwer, Warszawa 2011.

http://physicalinternetinitiative.org/ [12.01.2015].

http://www.etp-logistics.eu/ [06.01.2016].

http://www.modulushca.eu/ [12.01.2015].

http://www.log24.pl/artykuly/logistyczny-internet,5846 [06.01.2016].

http://www.scdigest.com/assets/FIRSTTHOUGHTS/13-06-06A.php?cid=7116 [12.01.2015].

http://faculty.ineg.uark.edu/rmeller/web/CELDi-PI/index-PI.html\# [12.01.2015].

http://www.plpt.com.pl/do_pobrania/plpt_4.pdf [12.01.2015].

http://www.logisticsmgmt.com/view/physical_internet_initiative_pipedream_or_possibility/sustainability [12.01.2015].

https://www.cirrelt.ca/DocumentsTravail/CIRRELT-2011-03.pdf [12.01.2015]. 
Studenckie Koło Naukowe Zarządzania Łańcuchem Dostaw 90-237 Łódź, ul. Matejki 22/26 www.scm.uni.lodz.pl 